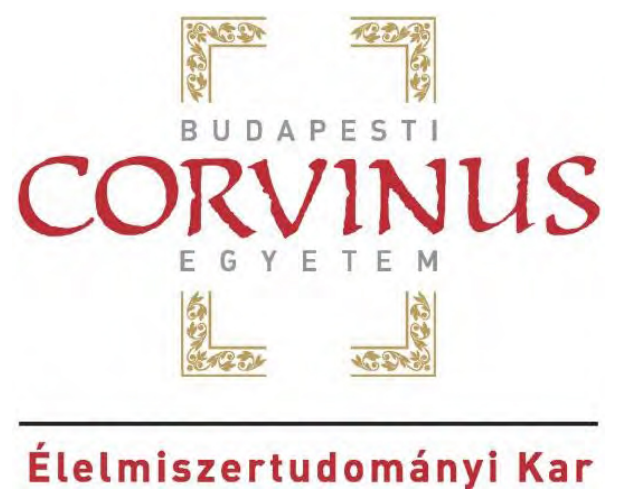

\title{
A FENOLOS ÉRETTSÉG VIZSGÁLATA SYRAH SZŐLŐFAJTÁN
}

Doktori $(\mathrm{PhD})$ értekezés

Villangó SZABOLCS

Témavezetők:

Dr. Pásti György, PhD

Dr. Zsófi Zsolt, PhD

Budapest 


\section{A doktori iskola}

megnevezése: $\quad$ Élelmiszertudományi Doktori Iskola

tudományága: Élelmiszertudományok

vezetője: $\quad$ Dr. Felföldi József, $\mathrm{PhD}$

tanszékvezető, egyetemi tanár

Budapesti Corvinus Egyetem, Élelmiszertudományi Kar

Fizika-Automatika Tanszék

Témavezető: $\quad$ Dr. Pásti György, $\mathrm{PhD}$

megbízott tanszékvezető, egyetemi docens

Budapesti Corvinus Egyetem, Kertészettudományi Kar

Szőlészeti és Borászati Intézet

Borászati Tanszék

Társtémavezető: $\quad$ Dr. Zsófi Zsolt, $\mathrm{PhD}$

megbízott igazgató, főiskolai docens

Károly Róbert Főiskola Szőlészeti és Borászati Kutatóintézete, Eger

A jelölt a Budapesti Corvinus Egyetem Doktori Szabályzatában elöírt valamennyi feltételnek eleget tett, az értekezés mühelyvitájában elhangzott észrevételeket és javaslatokat az értekezés átdolgozásakor figyelembe vette, ezért az értekezés nyilvános vitára bocsátható. 
A Budapesti Corvinus Egyetem Élettudományi Területi Doktori Tanács 2015. év március 13-i határozatában a nyilvános vita lefolytatására az alábbi Bíráló Bizottságot jelölte ki:

\section{BÍRÁLÓ BIZOTTSÁG:}

EInöke:

Bisztray György Dénes, PhD, BCE

Tagjai:

Simonné Sarkadi Lívia, DSc, BCE

Kosáry Judit, DSc, BCE

Fodor Marietta, $\mathrm{PhD}, \mathrm{BCE}$

Győrffyné Jahnke Gizella, PhD, NAIK, Badacsony

Nyúlné Pühra Beáta, PhD, Nyakas Pincészet

Opponensek:

Stefanovitsné Bányai Éva, DSc, BCE

Barócsi Zoltán, PhD, SZIE

Titkár:

Leskó Annamária, $\mathrm{PhD}, \mathrm{BCE}$ 
DOI: $10.14267 /$ phd.2015023

„Ha majd elindulsz Ithaka felé, válaszd hozzá a leghosszabb utat, mely csupa kaland és felfedezés.

Neki köszönöd a szép utazást, mit nélküle sosem tehettél volna meg, hát mi mást várhatnál még Ithakától?

Nem csaphat be Ithaka, ha szegény is; a szerzett tudásból s tapasztalatból máris megtudhattad, mit jelent Ithaka."

Konsztantinosz P. Kavafisz (1863-1933) - Ithaka Fordította: Somlyó György

Feleségemnek, Hannának és Szüleimnek 


\section{TARTALOMJEGYZÉK}

1. BEVEZETÉS

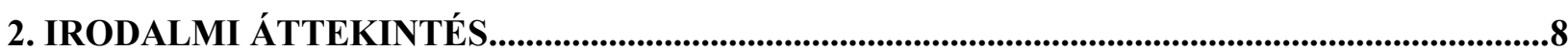

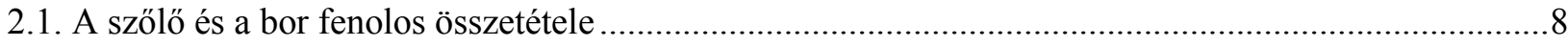

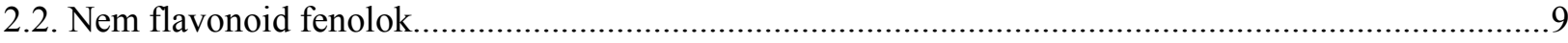

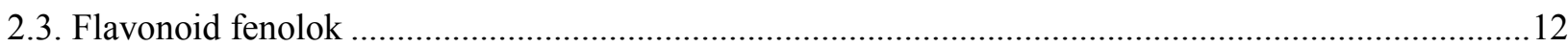

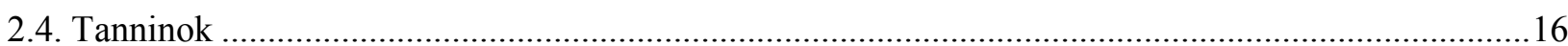

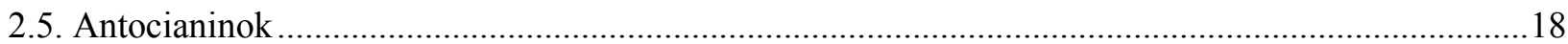

2.6. A fenolos anyagok kialakulása, változása a szőlő érése során .........................................................20

2.7. A bogyók fizikai paramétereinek alakulása az érés során..............................................................21

2.8. A fenolos érettséget befolyásoló környezeti tényezök …….............................................................22

2.9. A fenolos érettséget elősegítő szőlészeti beavatkozások ……............................................................23

2.10. A fenolos érettség meghatározásának módszerei ................................................................................25

2.11. A borászati technológia hatása a bor fenolos összetételére ............................................................27

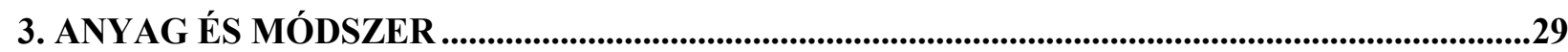

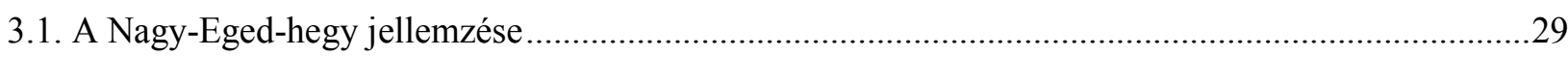

3.2. A kísérleti parcella jellemzése

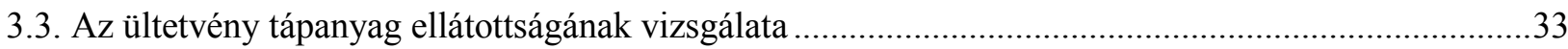

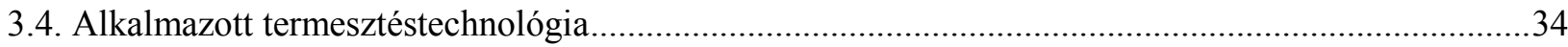

3.5. A vizsgált szölöfajta (Syrah) jellemzése ……....................................................................................

3.6. A kezeléshez felhasznált lombtrágya, a LalVigne ${ }^{\circledR}$ Mature...............................................................36

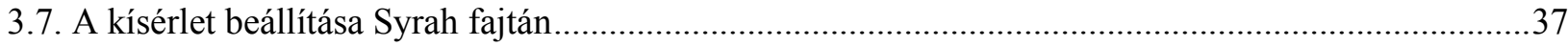

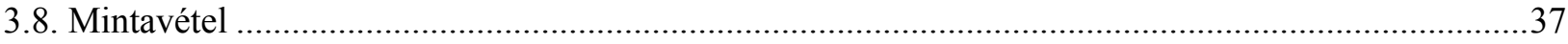

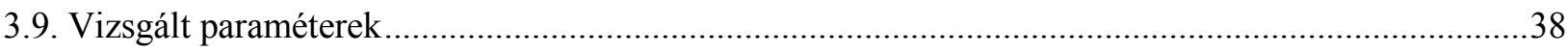

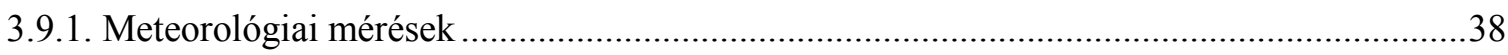

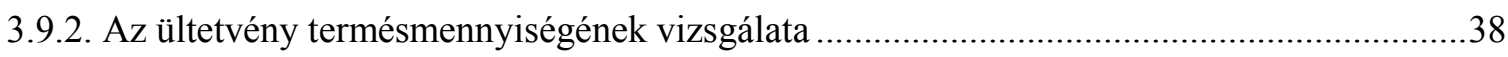

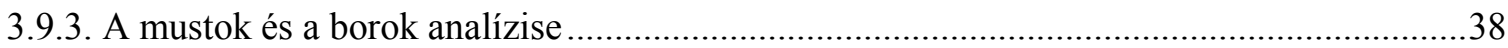

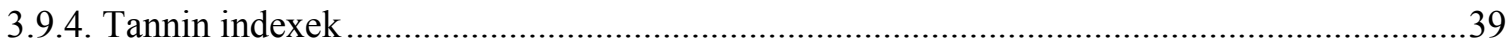

3.9.5. A fenolos érettség mérése Glories módszerével...................................................................39

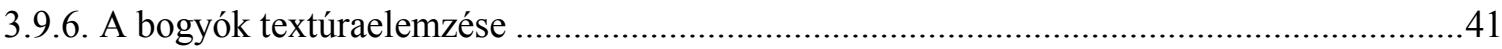

3.9.7. A borok rezveratroltartalmának meghatározása HPLC-vel...................................................46

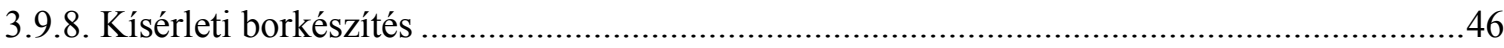

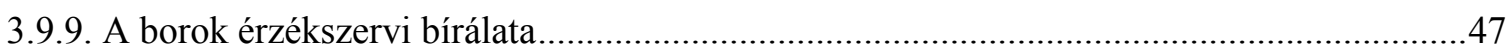

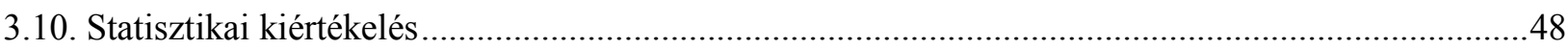

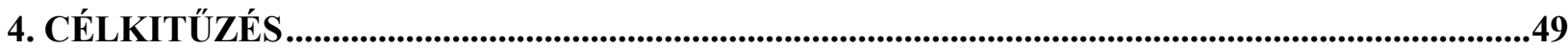




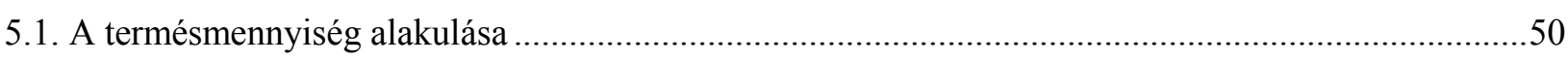

5.2. A termés alapanalitikai paramétereinek változása az érés során, a 2011-es évjáratban......................52

5.3. A termés alapanalitikai paramétereinek változása az érés során, a 2012-es és a 2013-as évjáratban ..52

5.3.1. Cukortartalom.

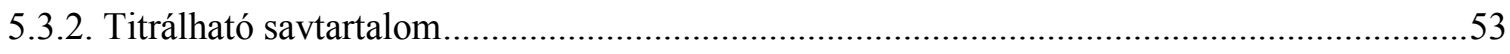

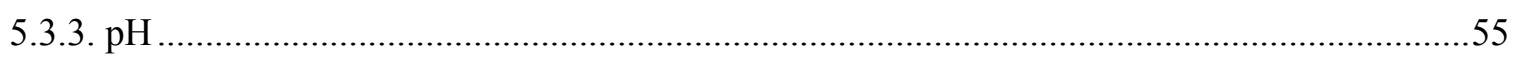

5.4. A szőlő fenolos érettségének változása a 2011-es évjáratban ...........................................................56

5.5. A szőlő fenolos érettségének változása a 2012-es és a 2013-as évjáratban .......................................56

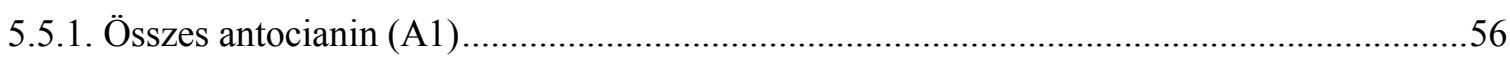

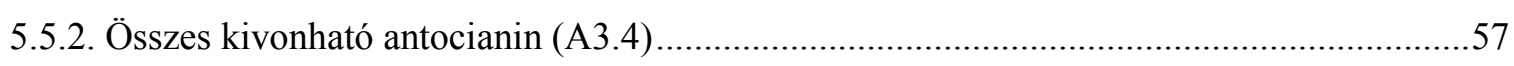

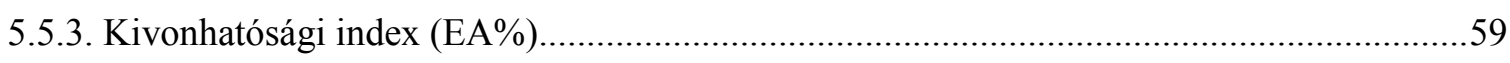

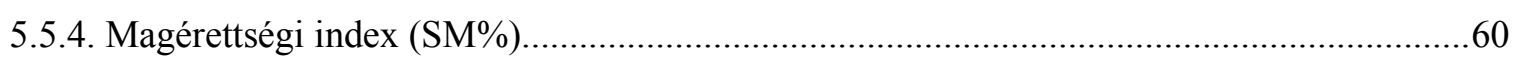

5.6. A szőlő fizikai paramétereinek változása a 2011-es évjáratban ........................................................61

5.7. A szőlő fizikai paramétereinek változása a 2012-es és 2013-as évjáratban ........................................62

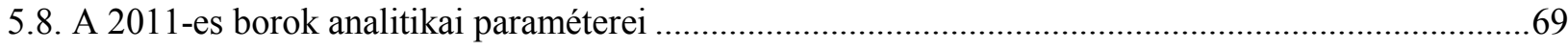

5.9. A 2012-es és 2013-as borok analitikai paraméterei ……................................................................70

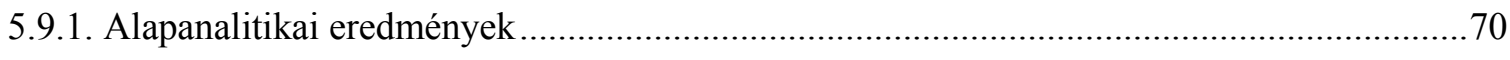

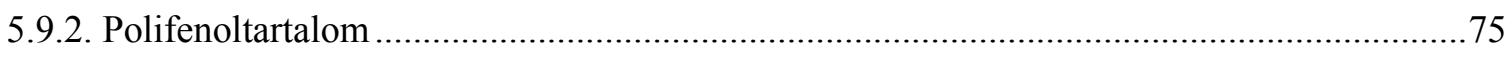

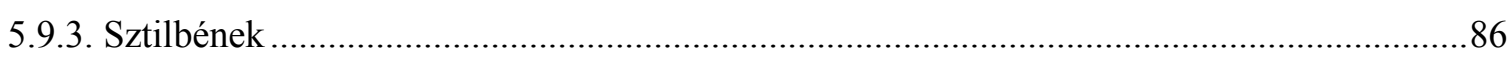

5.10. A borok érzékszervi bírálata és a kapott eredmények értékelése profilanalízissel...........................91

5.10.1. A 2011-es évjárat......................................................................................................

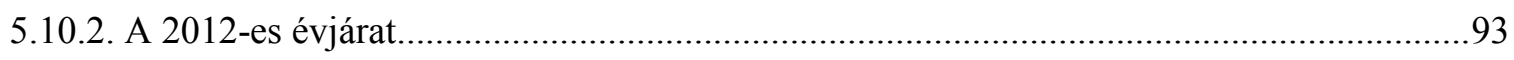

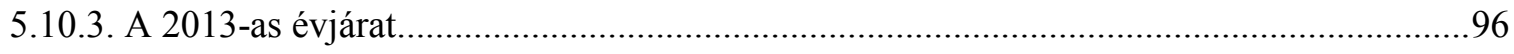

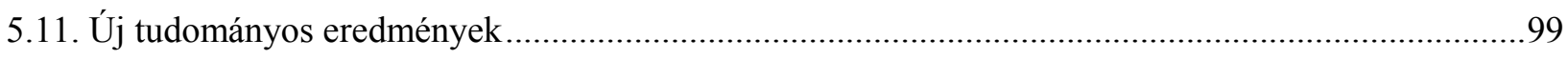

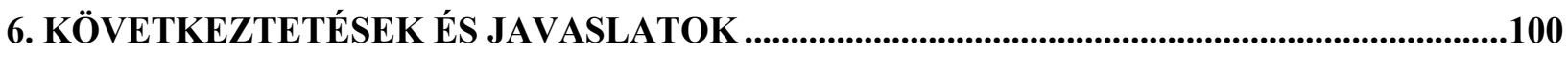

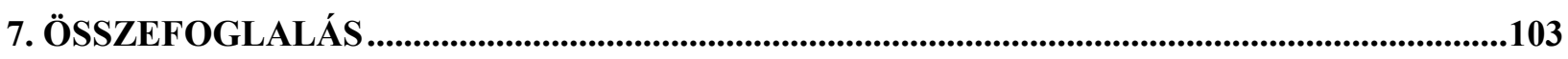

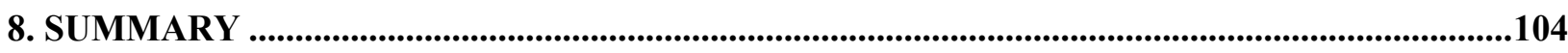

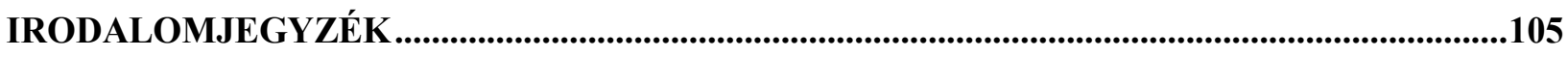

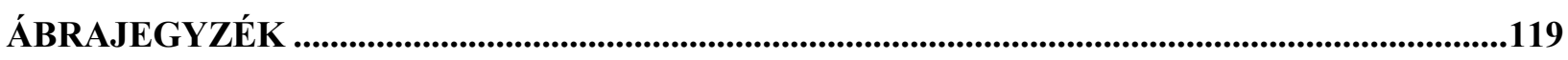

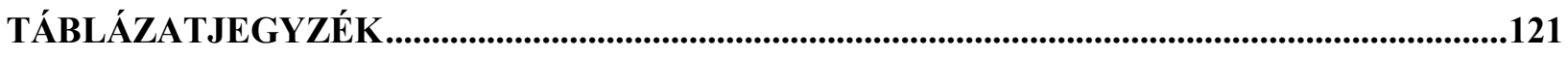

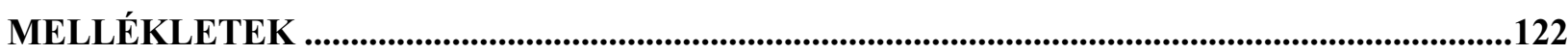

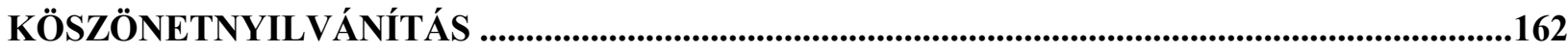




\section{BEVEZETÉS}

A szőlő egyike az emberiség legrégebbi idők óta termesztett kultúrnövényeinek, így a bor joggal pályázhat az egyik legősibb alkoholos ital címre. Mi sem bizonyítja ezt jobban, minthogy már az ókorban is nagy népszerüségnek örvendett és sok misztikum füződött hozzá, elég, ha csak a görögökre és a rómaiakra gondolunk, akik külön istenséget is szenteltek neki. A görögök már korán felismerték a borban rejlő sokféle lehetőséget és több hatást is tulajdonítottak neki. Az egyes hatásokat egy képzeletbeli háromszög csúcsain ábrázolták, ahol az egyik csúcs táplálékot jelentett, a másik orvosságot, a harmadik mérget. Ezzel a meghatározással ma is egyetérthetünk. Napjainkra a bor és fogyasztása a gasztronómia szerves részévé vált. A kiemelkedő minőség egyre keresettebb. Ha vörösborra terelődik a szó, a fogyasztók a mélyvörös színü, tartalmas, lágy, érett tanninokkal rendelkező, egész szájat betöltő, nagy beltartalmi értékü, gyümölcsös illatú borokat részesítik előnyben (BRUWER et al. 2011). Ahhoz, hogy ilyen adottságú bor születhessen, elengedhetetlen az, hogy a szőlő elérje a fenolos érettséget, lehetőleg még a túlérés előtt. Mindazonáltal a klímaváltozás hatása a szőlőtermesztésben is markánsan érezteti hatását, ami az érési folyamatok befolyásolásában is megnyilvánul. Ezek a hatások másként jelentkeznek a meleg és a hűvös klímájú szőlőtermesztő régiókban. A jövőben a mediterrán országokban a vízhiány és az aszály fogja a fő gondot jelenteni. Ezzel szemben a hűvösebb klímával rendelkező országok és borvidékek, mint hazánk és az Egri Borvidék esetében, egyre gyakrabban számíthatunk extrém időjárási elemek megjelenésére, mint pl.: egyenlőtlen csapadékeloszlás, aszály, szárazság, enyhe tél, hüvös nyár (Schultz 2000, 2003; WeBB et al. 2012; WeBB et al. 2013). Ezt a megállapítást jól példázza az elmúlt öt év. Ilyen és ehhez hasonló szélsőségek az elkövetkező évjáratokban is megjelenhetnek. 2010-ben az özönvíz szerü esővel és hüvös nyárral kellett a termesztőknek megküzdeni. Ezzel szemben 2011. és 2012. az átlagnál jóval szárazabb, aszályos évjáratokat hozott. Legszembetűnőbb a szőlőbogyók cukortartalmának növekedése, amelyet a fenolos érettség nem minden esetben képes követni. 2013. és 2014. sem „maradhatott ki” a sorból. Ezekben az években a mérsékelt tél miatt áttelelt kórokozók és kártevők adták fel a leckét. A nyár szinte „elmaradt”, a megszokottól jóval hüvösebb és csapadékosabb időjárásban volt részünk, amely az érési folyamatokat nagyon lelassította. A száraz, meleg évjáratokban az érési folyamatok felgyorsulnak és az egyensúly a fenolos és az úgynevezett cukorérettség között felborul (HANNAH et al. 2013). Ennek eredményeképpen a cukorfok gyorsan növekszik, miközben a savtartalom rohamosan csökken (MIRA DE ORDUÑA 2010; SADRAS ÉS MORAN 2012). Az ilyen alapanyagból készített borból hiányozni fog a harmónia. A savérzet lágy, az alkohol túlzó lesz. Ezzel szemben egy esős, hűvös évjáratban az érési folyamatok lelassulnak és a késői 
érésü fajták (pl.: Cabernet sauvignon, Cabernet franc, Syrah) nem tudnak kellően beérni. A fenolos érettség hiánya nyers, nagyon húzós, éretlen tanninú, bántó savérzetü borokat eredményez (JONES et al. 2005). A klímaváltozást jól szemléltetik az alábbi tények is: DélAnglia szőlőtermő területei bővülnek, Németországban pedig a vörösborszőlők egyre nagyobb arányban részesednek az összetermelésből. Ez a tendencia elsősorban az emelkedő átlaghőmérsékletek miatt jelentkezik, aminek hatására egyre északabbra tolódik a szőlőtermesztés határa. Magyarországon ez a változás bizonyos mértékig pozitívan hat a szőlőés borminőségre és elősegíti a késői fajták biztonságosabb termesztését. A fenolos érettséget elősegíthetjük különféle termesztéstechnikai beavatkozásokkal, valamint lombtrágyák alkalmazásával is, amelyek a flavonoidok szintézisére biostimulátorként hatnak. 


\section{IRODALMI ÁTTEKINTÉS}

\subsection{A szölö és a bor fenolos összetétele}

A vörösborok kiemelkedő figyelmet és sajtóvisszhangot kaptak az utóbbi években mind a kutatók, mind a fogyasztók részéről. Ez főként a „francia paradoxonnak” köszönhető. Ez a jelenség, a francia népesség körében aránylag alacsony számban előforduló szív- és érrendszeri betegségekre utal, dacára annak, hogy a lakosság nagy arányban fogyaszt telített zsírokat tartalmazó ételeket. Ezt az ellentmondást ugyanakkor a franciák világviszonylatban is rendszeres és mértékletes vörösborfogyasztásával magyarázzák (RENAUD ÉS DE LORGERIL 1992). A vörösborokban található fenolos vegyületek számos kedvező élettani hatással bírnak, amik az erős antioxidáns tulajdonságra vezethetőek vissza (KINSELLA et al. 1993). Ez azt jelenti, hogy hatékonyan semlegesítik a sejtre káros agresszív molekulákat, az úgynevezett szabadgyököket. Ezzel összefüggésben számos pozitív élettani hatást tulajdonítanak a vörösboroknak: koleszterinszint csökkentő, daganat gátló, fekély gátló, trombózis gátló, értágító, gyulladás gátló stb. (DÁVALOS ÉS LASUNCIÓN 2009). Ezek a tulajdonságok mind hozzájárulnak a szívinfarktus, a magas vérnyomás, a rák és az idő előtti öregedés megelőzéséhez, de legalábbis kialakulásuk, előfordulásuk csökkentéséhez (DÁVALOS ÉS LASUNCIÓN 2009). A fenolos vegyületek a szőlőből, a borba biológiai aktivitásuk megtartásával kerülnek át. Többek között ez az egyik magyarázata a borok - különösen a vörösborok - pozitív élettani hatásának. Hangsúlyozni kell azonban, hogy a túlzott alkoholfogyasztás már megszünteti ezeket a pozitív hatásokat, valamint súlyosan károsítja a szervezet egészét. A polifenolok a növényi életmüködés másodlagos anyagcseretermékei. Ezek a molekulák adják a virágok, gyümölcsök és zöldségek színét, valamint befolyásolják ezeknek a terményeknek az ízét. Védik a növényeket az ultraibolya sugárzástól, a szabad gyököktől, a különböző növényi kórokozóktól és kártevőktől, valamint az enzimreakciókat is befolyásolják. A fenolos alkotórészek közé számos vegyület tartozik. Kémiai szempontból a polifenol vegyületeknek a fenol az alapja. Ez egy 6 szénatomot tartalmazó aromás gyürü, amelyhez egy hidroxil csoport (-OH) kapcsolódik (1. ábra).

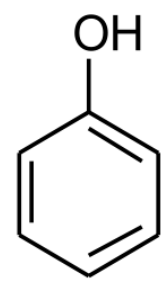

1. ábra - Egyszerü fenol vegyület felépítése 
Kiemelendő a vegyületcsoport oxidációra való érzékenysége, valamint polimerizációra való hajlama, továbbá az a tény, hogy a különböző formák (aglükon-glükozid, monomer-polimer stb.) egymás mellett találhatók meg a borban. A fenolos összetevőket két nagy csoportra bonthatjuk: flavonoid fenolok (közös jellemzőjük a C6-C3-C6 váz) és nem flavonoid fenolok. Ezen a két csoporton belül számos további alcsoportot különböztethetünk meg (2. ábra). Az alábbiakban a szőlő és a bor legfontosabb, legnagyobb mennyiségben előforduló fenolos vegyületei kerülnek bemutatásra. Megjegyzendő azonban, hogy a vegyületcsoport intenzív kutatásának hála újabb és újabb vegyületeket, polimer formákat sikerül kimutatni szölőből és borból egyaránt.

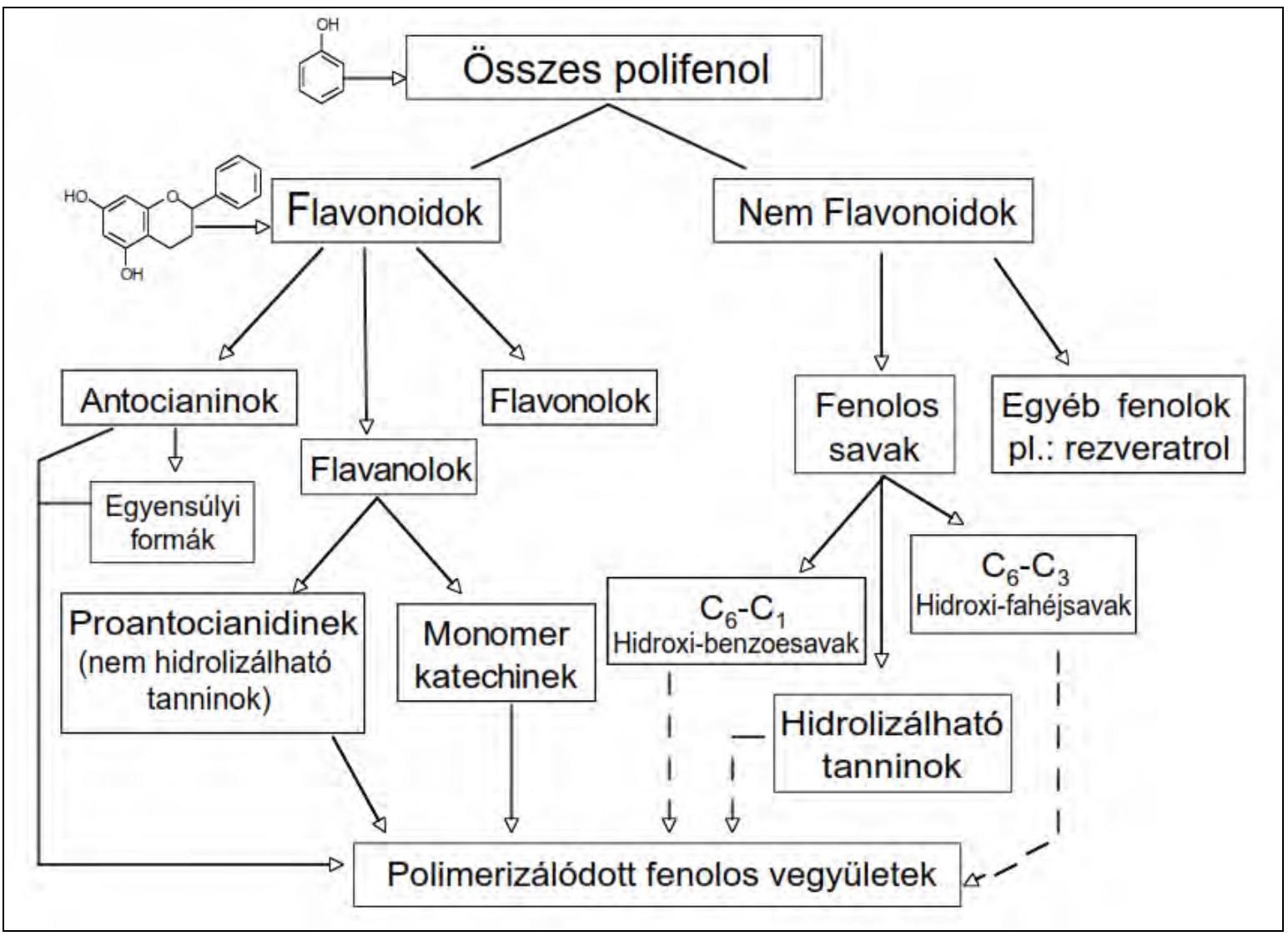

2. ábra - A bor fenolos összetevőinek csoportosítása. A szaggatott vonallal jelölt reakcióutak kevésbé valószínủek, mint azok, amelyek folyamatos vonallal jelöltek (SCOLLARY 2010)

\subsection{Nem flavonoid fenolok}

\section{Fenolos savak (egyszerü fenolok)}

A fenolos savakat hidroxi-benzoe (C6-C1 váz) és hidroxi-fahéjsavakra (C6-C3 váz) oszthatjuk, utóbbiak főként borkősavval alkotott észterek formájában vannak jelen (kutársav, fertársav, kaftársav) (3. ábra). Ezekre a vegyületekre a transz helyzet a jellemző, habár kis 
mennyiségben cisz formájuk is jelen lehet a szőlőben. Érzékszervileg a kevésbé összehúzó íz a jellemző rájuk, emellett színtelenek, esetenként halványsárga színüek lehetnek. Közös jellemzőjük, hogy majdnem kizárólag a bogyóhúsban találhatóak meg. A szőlőben és a borban előforduló legfontosabb fenolos savakat a 3. ábra mutatja be.<smiles>[R]c1cc(C(=O)O)c([R])c([R])c1[R]</smiles>

\begin{tabular}{ccccc}
\hline Hidroxi-benzoesavak & $\mathbf{R}_{\mathbf{1}}$ & $\mathbf{R}_{\mathbf{2}}$ & $\mathbf{R}_{\mathbf{3}}$ & $\mathbf{R}_{\mathbf{4}}$ \\
\hline$p$-hidroxi-benzoesav & $\mathrm{H}$ & $\mathrm{H}$ & $\mathrm{OH}$ & $\mathrm{H}$ \\
protokatechusav & $\mathrm{H}$ & $\mathrm{OH}$ & $\mathrm{OH}$ & $\mathrm{H}$ \\
vanillinsav & $\mathrm{H}$ & $\mathrm{OCH}_{3}$ & $\mathrm{OH}$ & $\mathrm{H}$ \\
veratrumsav & $\mathrm{H}$ & $\mathrm{OCH}_{3}$ & $\mathrm{OCH}_{3}$ & $\mathrm{H}$ \\
galluszsav & $\mathrm{H}$ & $\mathrm{OH}$ & $\mathrm{OH}$ & $\mathrm{OH}$ \\
sziringinsav & $\mathrm{H}$ & $\mathrm{OCH}_{3}$ & $\mathrm{OH}$ & $\mathrm{OCH}_{3}$ \\
szalicilsav & $\mathrm{OH}$ & $\mathrm{H}$ & $\mathrm{H}$ & $\mathrm{H}$ \\
gencizinsav & $\mathrm{OH}$ & $\mathrm{H}$ & $\mathrm{H}$ & $\mathrm{OH}$ \\
\hline
\end{tabular}<smiles>[R]c1cc(/C=C/C(=O)OC(C(=O)O)C(O)C(=O)O)ccc1O</smiles>

\begin{tabular}{cccc}
\hline Hidroxi-fahéjsavak & $\mathbf{R}_{\mathbf{1}}$ & $\mathbf{R}_{\mathbf{2}}$ & $\mathbf{R}_{\mathbf{3}}$ \\
\hline$p$-kumársav & $\mathrm{H}$ & $\mathrm{OH}$ & $\mathrm{H}$ \\
kávésav & $\mathrm{OH}$ & $\mathrm{OH}$ & $\mathrm{H}$ \\
ferulasav & $\mathrm{OCH}_{3}$ & $\mathrm{OH}$ & $\mathrm{H}$ \\
szinapinsav & $\mathrm{OCH}_{3}$ & $\mathrm{OH}$ & $\mathrm{OCH}_{3}$
\end{tabular}

\begin{tabular}{cc}
\hline Hidroxi-fahéjsav észterek & $\mathbf{R}$ \\
\hline $\begin{array}{c}\text { transz-kaffeoil-tartarát } \\
\text { (kaftársav) }\end{array}$ & $\mathrm{OH}$ \\
$\begin{array}{c}\text { transz-p-kumaroil-tartarát } \\
\text { (kutársav) } \\
\text { transz-feruloil-tartarát } \\
\text { (fertársav) }\end{array}$ & $\mathrm{H}$ \\
\hline
\end{tabular}

3. ábra - A szőlö és a bor fenolos savai (MONAGAS et al. 2005)

\section{Sztilbének}

A sztilbének kis molekulasúlyú fenolos vegyületek, amelyek a szőlő esetében főként a bogyó héjában fordulnak elő, de ezen kívül jelen lehetnek számos más szervben is, mint pl.: levél, kocsány, gyökér. A növényekben biotikus (patogén gombák okozta fertőzések, pl.: botritisz) és abiotikus stressz (ultraibolya sugárzás, mechanikai sérülés) hatására képződnek, tehát fitoalexinekként, azaz „védekező” anyagként tekinthetünk rájuk (JEANDET et al. 1991). A kutatások homlokterében a rezveratrol (3,5,4'-trihidroxi-sztilbén) áll, ami egyike az utóbbi évtizedek legintenzívebben kutatott vegyületeinek. A rezveratrolhoz gyakran egy cukormolekula kapcsolódik, $\beta$-glükozidos kötéssel, ezt a formát piceidnek nevezzük (4. ábra). A rezveratrolnak, ezáltal a piceidnek is kétféle térbeli izomer formája (transz és cisz) létezik (MATTIVI et al. 1995). A sztilbének a monomer formákon túl oligomerekként és polimerekként is előfordulnak, ezeket 
viniferineknek hívjuk (RENTZSCH et al. 2009). Érzékszervi szerepük nincs, de biológiailag aktív vegyületek. Erős antioxidáns, szív- és érrendszeri betegségeket megelőző, öregedést gátló, rákellenes, gyulladáscsökkentő és idegvédő hatásuk miatt jelentős szerepet tulajdonítanak nekik az emberi egészség megőrzésében (PÉREZ-LÓPEZ et al. 2009). Koncentrációjuk a szőlőben számos tényezőtől függ: fajta, klíma, időjárás, ultraibolya sugárzás, termesztéstechnológia, gombafertőzés, sőt a tengerszint feletti magasság (JEANDET et al. 1995; BAVARESCO 2003; BAVAResCo et al. 2007; PrAJITNA et al. 2007). A transz változatok UV fény hatására cisz formává alakulnak (SIEMANN ÉS CREASY 1992). Az alkalmazott borászati technológia is hatással van koncentrációjukra (MATTIVI et al. 1995; GAMBUTI et al. 2004). Mennyiségi és minőségi összetételük a borélesztők izomeráz (transz-cisz átalakulás) és $\beta$-glükozidáz (piceid $\rightarrow$ rezveratrol) enzimaktivitásától is függ (JEANDET et al. 1994), de a biológiai almasavbomlás ugyancsak befolyásoló tényező a piceid-rezveratrol átalakulás során (PoUSSIER et al. 2003). Figyelemre méltó, hogy a rezveratrolt sokan már-már „csodaelixírnek” kiáltották ki. A kezdetekben tapasztalható lelkesedés azonban csillapodni látszik, mivel az előbbiekben említett számos pozitív élettani hatás közül végül sokat nem, vagy csak kis mértékben sikerült igazolni az emberi szervezetben (WIKIPEDIA 2014). Meg kell említeni továbbá azt is, hogy a bor csak kis mennyiségben tartalmazza (néhány $\mathrm{mg} / \mathrm{l}$ ) a rezveratrol típusú vegyületeket, ráadásul ezeknek is csak kis százaléka éri el a vérkeringést eredeti alakjában, így olyan nagy mennyiségü borbevitel válna szükségessé, ami az esetleges pozitív hatásokat már jócskán kioltaná. Sokkal inkább az a valószínü, hogy a bor összes polifenoltartalma, semmint egyetlen vegyület az, ami miatt a bort mértékletesen fogyasztva, a pozitív élettani hatások jelentkezhetnek (FRICKNÉ ÁdÁM et al. 2013).
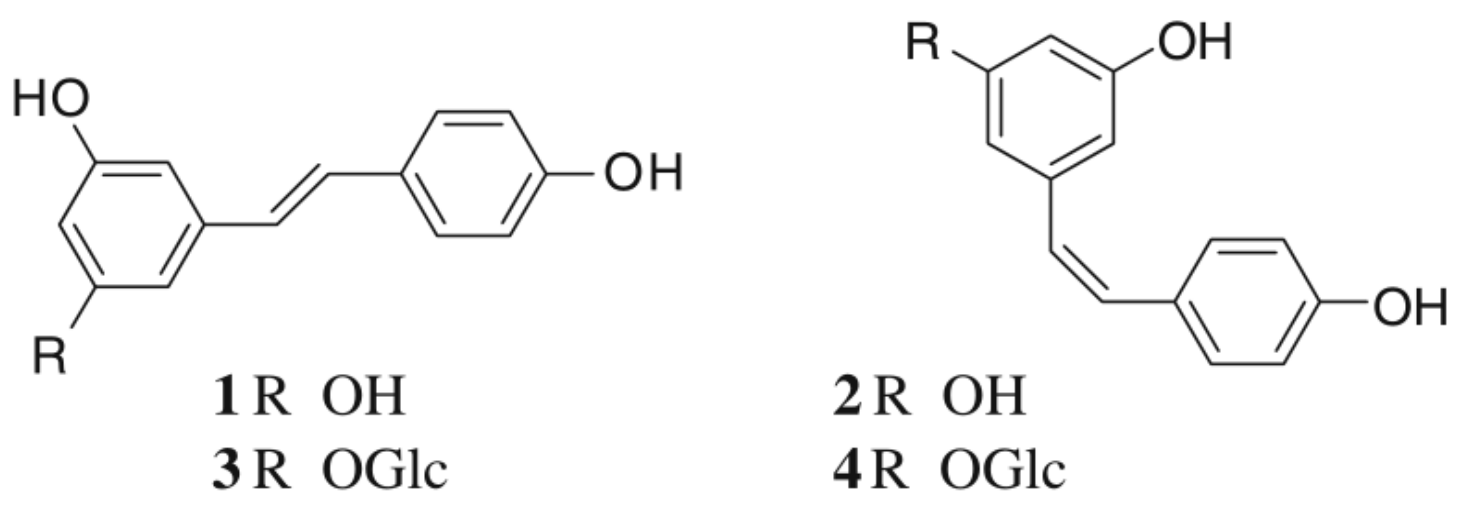

4. ábra - 1: transz-rezveratrol; 2: cisz-rezveratrol; 3: transz-piceid; 4: cisz-piceid; Glc: glükóz (RENTZSCH et al. 2009) 


\subsection{Flavonoid fenolok}

Ebbe a vegyületcsoportba soroljuk a katechin-, a leukoantocianin- és az antocianinmonomereket. Ezek a monomer molekulák a procianidinek építőköveinek tekinthetők, hiszen belölük épülnek fel a különböző polimerizációs fokú és összetételü származékok a dimerektől egészen a hexamerekig. Az alapvegyületek nagy száma jellemző, amit a gyürükön előforduló eltérő számú és elhelyezkedésű hidroxilcsoportok eredményeznek. Tovább emeli a variációk számát a hidroxilcsoportok metilálása, illetve az, hogy a flavonoidok rendszerint glükozidos alakban fordulnak elö. A glükonrészek leggyakrabban az aglükonok C gyürüjének 3-as, ritkábban A gyürüjének 5-ös illetve 7-es szénatomján lévő hidroxil csoportok hidrogénjének cukorral vagy acilezett cukrokkal való helyettesítése révén kapcsolódnak (5. ábra). A kapcsolódó cukrok változatosak, általában glükóz, galaktóz, ramnóz és arabinóz stb. Az acilezett cukrok acil részei elsősorban fenol-karbonsavak (p-kumársav, kávésav, ferulasav). A flavonoidok általános kémiai tulajdonsága, hogy könnyen oxidálhatók és jó fémmegkötő képességgel rendelkeznek, valamint könnyen reagálnak fehérjékkel (cserzőanyag) és egyéb polimerekkel (pl. poliszaharidok). Érzékszervileg keserü és összehúzó ízérzetet mutatnak, szerepük van az ún. borjelleg kialakításában és a borok barnulási folyamatiban, érlelhetőségében egyaránt. A szőlő kiemelkedően gazdag flavonoid vegyületekben (KÁLLAY 2010).

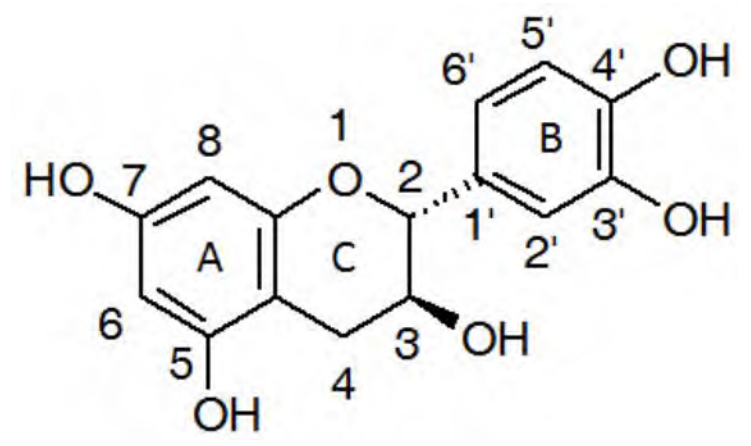

5. ábra - A szénatomok számozása és a gyürük betűjelzése flavonoid típusú fenolos vegyületek esetén (SCOLLARY 2010)

\section{Flavonolok}

A vegyületcsoport elnevezésében az -on végződés a 4-es szénatomhoz kettős kötéssel kapcsolódó oxigénre utal, míg az -ol, a hidroxil $(-\mathrm{OH})$ csoportra a 3. szénatomon, a $\mathrm{C}$ gyürün (6. ábra). A szőlőben négy olyan aglükont találtak, amelyek viszonylag nagy mennyiségben fordulnak elő: kaempferol, miricetin, kvercetin, izorhamnetin. A szőlőbogyó héjában főleg glükozidos formában vannak jelen (TERRIER et al. 2009). 
<smiles>O=c1c(O)c(-c2ccccc2)oc2ccccc12</smiles>

6. ábra - A flavonolok alapváza

\section{Katechinek (3-flavanolok)}<smiles>OC1Cc2ccccc2OC1c1ccccc1</smiles>

7. ábra - A katechinek (3-flavanolok) alapváza

A 3-flavanolok között (7. ábra) legnagyobb mennyiségben a (+)-katechin és a (-)epikatechin fordul elő (8. ábra). Ezek sztereoizomerjei egymásnak, azaz nem tükörképek és egymással fedésbe sem hozhatóak. A közöttük lévő különbség a 3. szénatomhoz kapcsolódó hiroxilcsoport (-OH) elhelyezkedésében van. A (+)-katechin esetében az -OH csoport a molekula síkja fölött van, a (-)-epikatechin esetében pedig alatta. Ez az elrendezésbeli különbség az alapja a sokféle oligomer (procianidinek) és polimer forma létrejöttének.<smiles>Oc1cc(O)c2c(c1)O[C@H](c1ccc(O)c(O)c1)C(O)C2</smiles><smiles>Oc1cc(O)c2c(c1)O[C@H](c1ccc(O)c(O)c1)[C@H](O)C2</smiles>

8. ábra - (+)-katechin balra és (-)-epikatechin jobbra

Ha egy további -OH csoport található a B gyürü 5. szénatomján akkor (+)gallokatechinről és (-)-epigallokatechinről beszélhetünk (9. ábra), mivel a 3 hidroxilcsoportosra bővült rész galluszsavként „funkcionál”. 
<smiles>Oc1cc(O)c2c(c1)O[C@H](c1cc(O)c(O)c(O)c1)[C@H](O)C2</smiles><smiles>Oc1cc(O)c2c(c1)O[C@H](c1cc(O)c(O)c(O)c1)[C@H](O)C2</smiles>

9. ábra - (+)-gallokatechin balra és (-)-epigallokatechin jobbra

Ha ezeknek a vegyületeknek a C gyürüjére további galluszsav észtereződik, akkor (+)-gallokatechin-gallátról (10. ábra), (-)-epigallokatechin-gallátról (11. ábra) beszélhetünk. A (-)-epikatechin-gallát esetében (12. ábra) a B gyürün csak két hidroxilcsoport található. A 3flavanolok nagy mennyiségben találhatóak meg a magban (PRIEUR et al. 1994), héjban (SOUQUET et al. 1996) és kocsányban (SOUQUET et al. 2000) egyaránt. Fontos szerepet játszanak a borok érzékszervi tulajdonságainak kialakításában, valamint érlelhetőségében.<smiles>O=C(OC1Cc2c(O)cc(O)cc2O[C@@H]1c1cc(O)c(O)c(O)c1)c1cc(O)c(O)c(O)c1</smiles>

10. ábra - gallokatechin-gallát 
<smiles>O=C(O[C@@H]1Cc2c(O)cc(O)cc2O[C@H]1c1cc(O)c(O)c(O)c1)c1cc(O)c(O)c(O)c1</smiles>

11. ábra - (-)-epigallokatechin-gallát<smiles>O=C(O[C@@H]1Cc2c(O)cc(O)cc2O[C@@H]1c1ccc(O)c(O)c1)c1cc(O)c(O)c(O)c1</smiles>

12. ábra - (-)-epikatechin-gallát

\section{Leukoantocianinok (3,4-flavandiolok)}

A leukoantocianinok a 3,4-flavandiol alapváz hidroxilezett származékai (13. ábra), színtelen vegyületek. Az antocianinok bioszintézise a leukoantocianinokon keresztül történik. Befolyásolják az érzékszervi tulajdonságokat, összehúzó ízük a polimerizációs fok függvénye (BATE-SMITH 1954). 
<smiles>OC1c2ccccc2OC(c2ccccc2)C1O</smiles>

13. ábra - A 3,4-flavandiol alapváz

\subsection{Tanninok}

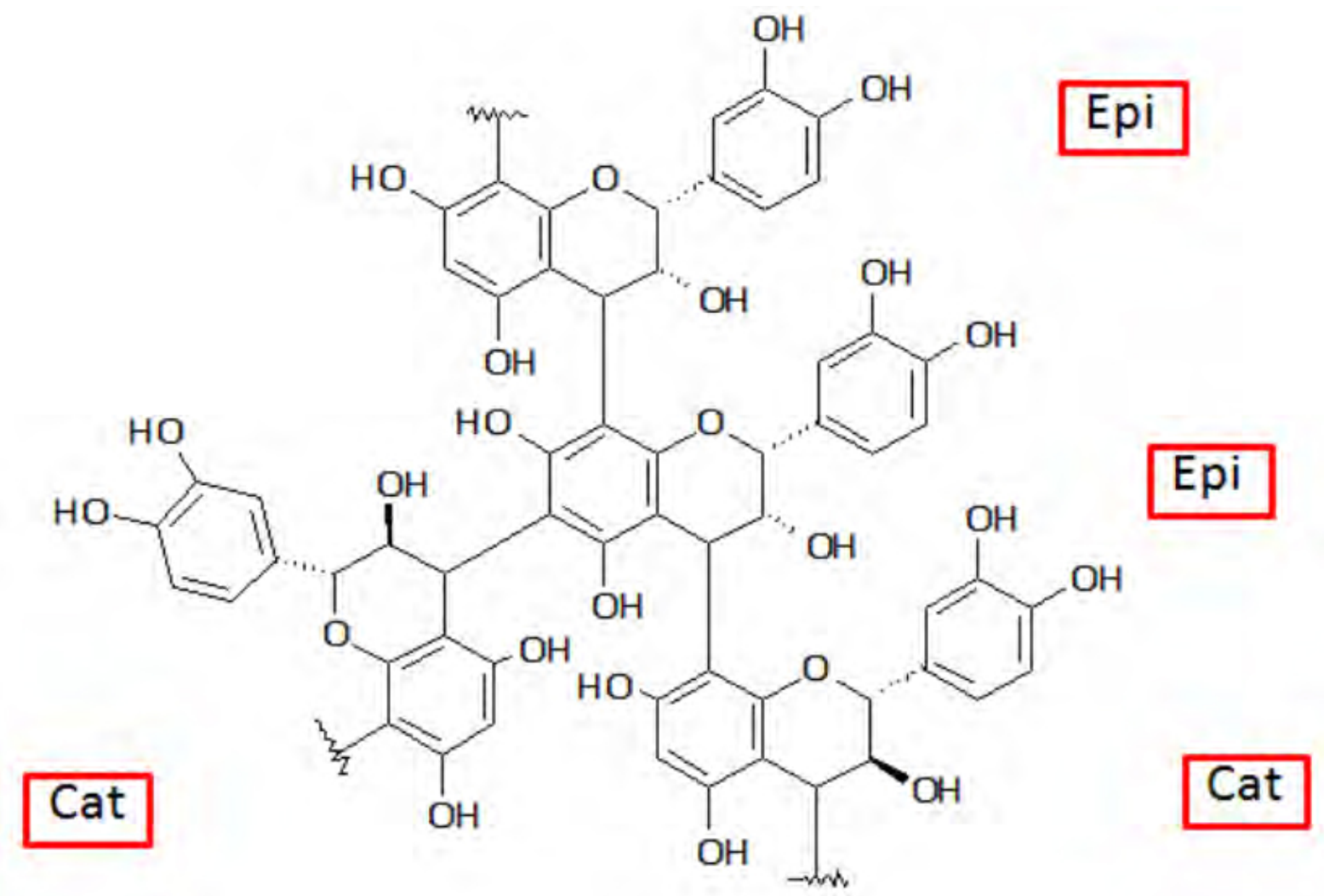

14. ábra - Példa egy (+)-katechinből (Cat) és (-)-epikatechinből (Epi) felépülő tannin szerkezetére (SCOLLARY 2010)

A tanninok két fő csoportra oszthatók, a hidrolizálható (nem szőlő eredetü) és a nem hidrolizálható (szőlő eredetű) tanninokra. A hidrolizálható tanninok részben a tölgyfahordókból, részben a derítések során használt borászati csersavkészítményekből, tehát a borkészítés során „külső” tanninként oldódhatnak a borba. Ezeket a szőlő nem tartalmazza. Polimerek, amelyek általában két hidroxi-benzoesavból alakultak ki. Két fó típusuk van, a gallotanninok, melyek galluszsavra hidrolizálnak, illetve az ellágtanninok, melyek ellágsavra bomlanak. Jól megkülönbözethetőek a tisztán a szőlőből származó tanninoktól, ugyanis ezek a tannin molekulák egy szénhidrát molekulát (általában D-glükózt) tartalmaznak a központi részükön. A 
szénhidrát hidroxilcsoportjai részben vagy teljesen észteresítve vannak gallusz- vagy ellágsavval (SCOLLARY 2010).

A borászati szakirodalomban a tannin szót sokrétüen, szerteágazóan használják. Sokan a proantocianidinek szót a kondenzált tanninok szinonimájának veszik, azonban célszerúbb ezt a kifejezést a kevesebb, mint 10 egységet tartalmazó 3-flavanol oligomerekre használni, a kondenzált tanninokat pedig az ennél hosszabb láncú polimerekre. A proantocianidineket tovább oszthatjuk, annak függvényében, hogy savas hidrolízissel cianidinekre, vagy delfinidinekre bomlanak-e. A procianidinek csak (+)-katechinekből és (-)-epikatechinekből állnak, míg a prodelfinidinek (+)-gallokatechin és/vagy (-)-epigallokatechin egységeket is tartalmaznak (PorTer et al. 1985). A kapcsolat egyik 3-flavanol monomer 4-es és a másik 8-as illetve 6-os szénatomja között jön létre (14. ábra). A polimerizálódási folyamat során az $\mathrm{A}$ és a $\mathrm{C}$ gyürük érintettek (SCOLLARY 2010). A vörösborokban megtalálható tanninok fontos minőségi tényezők, hiszen szerepet játszanak az érlelési potenciálban, az érzékszervi tulajdonságban, az enzimek deaktiválásában és a színstabilizációban, végérvényben a bor minőségében. Főként a szőlőbogyó héjában és magjában fordulnak elő. A két növényi részből kioldódó tanninok felépítésükben több szempontból is eltérnek egymástól, ezáltal jól megkülönböztethetőek. A héj tanninjai hosszabb láncúak, mint a magból származóak. Ezen túl a mag proantocianidinjei (+)-katechinböl, (-)-epikatechinből és (-)-epikatechin-gallátból épülnek fel (PRIEUR et al. 1994; KENNEDY et al. 2002), míg a héj proantocianidinjei esetében jóval kevesebb a (-)-epikatechin-gallát aránya és (-)-epigallokatechint és (+)-gallokatechint is tartalmaznak (SOUQUET et al. 1996; DowNEY et al. 2003). A magvak tannintartalma általában magasabb, mint a héjé, de a kioldhatóság a héjból jóval egyszerűbb és a mag tanninjai csak az erjedés későbbi szakaszában kezdenek a borba jutni (Harbertson et al. 2002; PeYrot des Gachons És Kennedy 2003). A mag és a héj tanninjai között az eltérő szerkezeti felépítés miatt, érzékszervileg is különbséget tehetünk. A magtanninok húzósabb ízérzetűek a héjtanninoknál (GAWEL 1998; PEYROT DES GACHONS ÉS KENNEDY 2003). Ez a magasabb polimerizáltsági fok és a galluszsav észterek nagyobb százaléka miatt van (VIDAL et al. 2003; HERDERICH ÉS SMITH 2005). A húzósság (idegen szóval astringencia) nem tekinthető íznek. Sokkal inkább nevezhetjük egy érzetnek a szájban. A nyelv nagyon érzékeny az érintésre és általában vékony réteg nyállal fedett. Ugyanígy vékony nyálréteg vonja be az ínyt, a fogakat és az ajkakat, így a nyelv könnyen tud siklani a szájban. A nyál nagy része víz, de tartalmaz egy sor olyan fehérjét, amelyek a kenő és nedvesítő hatásért felelősek. Azok az ételek és italok, amelyek eltávolítják ezeket a fehérjéket a nyálból, vagy csökkentik a nyál mennyiségét, szárítják a szájat, aminek következtében a nyelv nehezebben tud mozogni a szájban. Ezt a fokozott súrlódást, dörzsölődést érzékeljük húzósságnak. 
Összefoglalva: a húzósság egy szárazság, durvaság érzés, amelyet a nyelvünkkel érzünk a szájban található felületek fokozott súrlódása, dörzsölödése miatt (GAWEL 1998). Ezt a hatást a tanninoknak tulajdonítjuk, amelyek kicsapják a nyál azon fehérjéit, amelyek a „kenésért” felelősek. A monomerek jóval keserübb ízűek, viszont kevésbé húzósak, mint az oligomer proantocianidinek (GAWEL 1998). A 3-flavanolok összetétele elsősorban azoké, amelyek a magból származnak, befolyásolják a húzósságot és a tanninérzetet (nyersesség) a szőlöben és a borban. A húzósság és nyers ízérzet csökkenő tendenciát mutat az érés során (DEL LLAUDY et al. 2008). Ez a tény nem csak kizárólag a proantocianidinek mennyiségével van összefüggésben, mivel néha magasabb tannintartalmú minták kisebb húzósságot és tanninintenzitást mutatnak (FERRER-Gallego et al. 2010). A magyarázat a minőségi összetételben keresendő. Összességében kijelenthető, hogy a proantocianidinek molekulamérete és monomer-összetétele határozza meg a húzósság mértékét. A nem kellően érett szőlő héjából az antocianinok és proantocianidinek kivonhatósága korlátozott, ezzel szemben a magból kioldható proantocianidinek aránya magas (PEYROT DES GACHONS ÉS KENNEDY 2003; CANALS et al. 2005). Az éretlen szőlő ezáltal keserübb és húzósabb ízérzetü borokat ad, mert a magból nagyszámú olyan proantocianidin oldódik ki, amelyek nagyobb számban tartalmaznak galluszsavval észteresített alapegységeket (ROMEYER et al. 1985). Fontos tehát a helyes szüreti időpont megválasztása, amely feltételezi a fenolos érettség meglétét.

\subsection{Antocianinok}

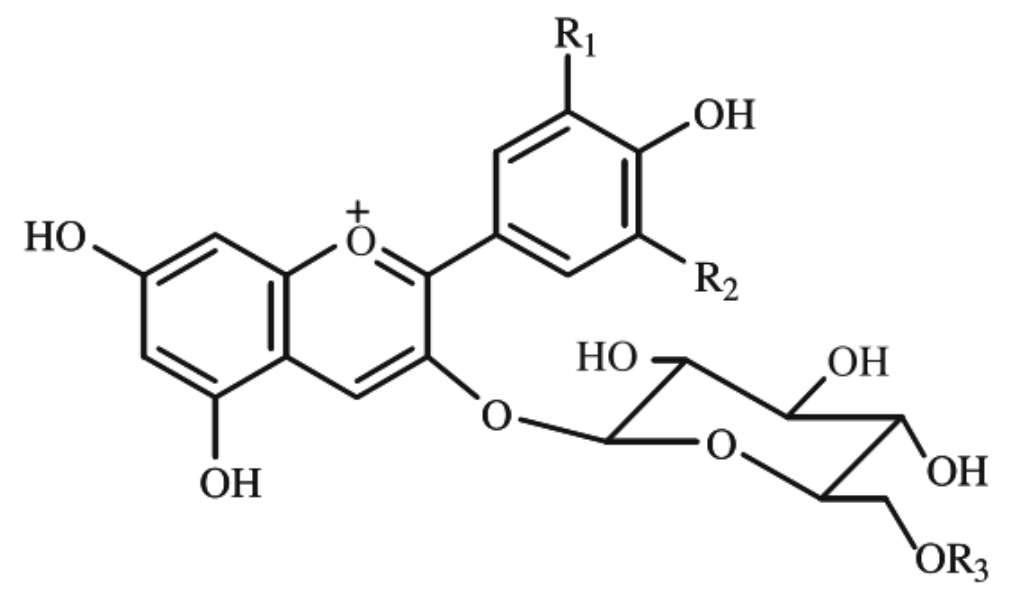

\begin{tabular}{ccc}
\hline Antocianidin & $\mathrm{R}_{1}$ & $\mathrm{R}_{2}$ \\
\hline Cianidin & $\mathrm{OH}$ & $\mathrm{H}$ \\
Delfinidin & $\mathrm{OH}$ & $\mathrm{OH}$ \\
Peonidin & $\mathrm{OCH}_{3}$ & $\mathrm{H}$ \\
Petunidin & $\mathrm{OCH}_{3}$ & $\mathrm{OH}$ \\
Malvidin & $\mathrm{OCH}_{3}$ & $\mathrm{OCH}_{3}$ \\
\hline
\end{tabular}

Balra - Az antocianidinekhez kapcsolódó cukormolekula $\rightarrow$ Antocianin

Jobbra - A szőlőben előforduló öt antocianidin szerkezeti felépítése.
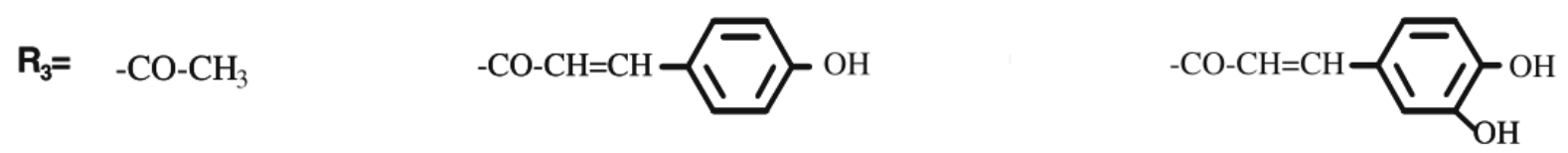

15. ábra - A cukormolekulára acileződött acetil (balra), p-kumársav (középen), kávésav (jobbra) Az ábrák forrása: MONAGAS ÉS BARTOLOMÉ (2009) 
Az antocianinok föként a vörösborszőlö-fajták bogyóhéjának bőrszövet alatti 3-4 sejtsorában helyezkednek el és ezek a vegyületek adják a vörösborok színét. Egyes szőlöfajták esetében (pl.: Turán, Bíborkadarka, Bíborfrankos, Teinturier stb.), a bogyó húsa szintén tartalmazza ezeket a színanyagokat, ezért ezeket festőlevü fajtának nevezzük. A szőlő antocianinjait a monomer antocianidinek, más néven aglükonok (delfinidin, petunidin, malvidin, peonidin, cianidin, pelargonidin) és ezek monoglükozidjai, valamint acilezett monoglükozidjai adják (CASTILlo-MuÑoz et al. 2009) (15. ábra). Direkttermő fajták esetében főleg 3,5diglükozidok kapcsolódnak (VIDAL et al. 2004; CASTILlo-MuÑOZ et al. 2009), de 3,7diklükozidok (ALCALDE-EON et al. 2006) is előfordulhatnak. A cukormolekula a vízben való oldhatóságot javítja, és megvédi a molekulát a kémiai vagy enzimes hatásoktól (pl. oxidációtól). Az antocianidinek esetében a flaviliumváz (2-fenil-benzo-pirillium) a közös, a különbség közöttük a B gyürün található hidroxil- és metoxil-csoportok számából és elhelyezkedéséből adódik (MONAGAS ÉS BARTOLOMÉ 2009). Az acileződés a glükóz molekula C-6-os pozíciójában megy végbe acetáttal, $p$-kumársavval vagy kávésavval történő észtereződés során (15. ábra), de akár tejsavval is történhet (ALCALDE-EON et al. 2006). A szőlőben és a borban az antocianidinek acetil-3-monoglükozidjai és kumaroil-3-monoglükozidjai a legdominánsabbak. A malvidin- és peonidin kaffeoil-3-monoglükozidjait csak kis koncentrációkban mutatták ki (BALDI et al. 1995) és a cianidin, delfinidin és petunidin kaffeoil-3-monoglükozidjainak jelenléte is csak néhány esetben igazolt (VIDAL et al. 2004; ALCALDE-EON et al. 2006). A fiatal vörösborokban az antocianinok föleg monomer formában vannak jelen. A fiatal vörösboroknál megfigyelhető jelenség a kopigmentáció (BOULTON 2001). Ez egy kondenzációs folyamat, amely során a pigmentek ideiglenesen összeállnak más (általában nem színes) fenolos vegyületekkel. A kopigmentek, vagy más néven kofaktorok lehetnek: fenolos savak, 3-flavanolok és részben flavonolok. A fiatal vörösborok színéért ezek a kopigmentek felelnek 30-50\%-ban. Ez okozza az élénk kékes-lilás árnyalatot, ami a bor érésével csökken (BOULTON 2001). A kopigmentált antocianinok kén-dioxid hatására elszíntelenednek. Az antocianin pigmentek színüket a pH függvényében változtatják, de a bor pH-ján egyensúlyi állapot áll fenn a különböző formák közt. A piros flavílium forma, amelynek az alacsony $\mathrm{pH}$ a függvénye csak kis mennyiségben van jelen. Az antocianinok nagyobbik része színtelen, vagy gyengén színeződött formában fordul elő. A bor érése során a polimer pigmentek aránya megnő. Ezek a pigmentek kulcsszerepet játszanak a vörösborok színstabilitásának kialakításában, mivel ellenállóbbak a kén színtelenítő hatásával szemben és a $\mathrm{pH}$ értékben történt változásokra is kevésbé érzékenyek, mint az antocianin monomerek (SOMERS 1971). Az antocianinok nem csak egymással, de tanninokkal is összekapcsolódhatnak. A vörösborok színe az erjedés lefutásától (spontán, irányított) is függ (LESKÓ et al. 2014). A biológiai almasavbomlás során a borban található almasav tejsavvá 
alakul, amely pH növekedéssel jár együtt és ez szintén kihat az antocianin egyensúlyra. Az oxigén is kulcsfontosságú szerepet játszik (a tanninok kémiai átalakulásai közötti katalizátorának tekinthető) a színstabilitás kialakításában és a húzósság érzet csökkentésében (DEL LLAUDY et al. 2006; KONTOUDAKIS et al. 2011c). A fiatal vörösborok általában ragyogó vörös színủek, enyhe kékes-lilás árnyalattal. Ezzel szemben a hosszú időn át érlelt vörösborokra egy bizonyos idő után a téglavörös vagy barnás szín lesz a jellemzö. Ez a szabad antocianinok és a polimer pigmentek eltérő fényelnyelésére vezethető vissza (SOMERS 1971). A túl nagy és hosszú láncú polimerek képződése esetén színanyagkiválás is bekövetkezhet.

Az elmúlt években újabb antocianin típusú vegyületeket is sikerült a borokból kimutatni, amelyek az eddig ismertektől némileg eltérő felépítésűek. Ezeket összefoglaló néven piranoantocianinoknak nevezik és közéjük tartoznak pl.: a vitisinek, pinotinok és portosinok (DE Freitas És Mateus 2011).

\subsection{A fenolos anyagok kialakulása, változása a szölö érése során}

A héj- és magtanninok kialakulása lényegében már a zsendülésig teljesen végbemegy. Mennyiségük kicsivel a zsendülés után éri el a maximumot és a szüret időpontjáig fokozatosan csökken, amely inkább kivonhatóságuk romlásával, mintsem lebomlásukkal van összefüggésben (CHEYNIER et al. 1997; DE FrEITAS ÉS GLORIES 1999; KENNEDY et al. 2001; HARBERTSON et al. 2002; DOWNEY et al. 2003; CADOT et al. 2006). A további érés folyamatában valószínúleg a lekötődés miatt figyelhető meg a csökkent kivonhatóság (KENNEDY et al. 2000a; KENNEDY et al. 2000b; DOWNEY et al. 2004). Az antocianinok kialakulása azonban éppen a zsendüléssel veszi kezdetét, majd egy csúcspont elérése után (FERNÁNDEZ-LÓPEZ et al. 1992; KENNEDY et al. 2002; CANALS et al. 2005) mennyiségük csökkenni kezd. Ez a csökkenés általában már a túlérést jelzi (MATEUS et al. 2002; RYAN ÉS REVILla 2003; FOURNAND et al. 2006). A proantocianidinek változása nem egyértelmü. Egyes szerzők arról számolnak be, hogy a bogyók proantocianidin tartalma az érés során csökken (DE FrEITAS ÉS GLORIES 1999; HARBERTSON et al. 2002; DOWNEY et al. 2003), míg mások éppen ennek az ellenkezőjéről (DELGADO et al. 2004; CANALS et al. 2005). A polimerizáltsági fok változásával kapcsolatban is ellentmondások vannak. KENNEDY et al. (2000a), KENNEDY et al. (2000b), KENNEDY et al. (2001), KENNEDY et al. (2002) szerint növekszik, DowNEY et al. (2003) szerint pedig csökken az érés során. A kialakult színanyagok, a héj- és magtanninok mennyisége, illetve összetétele elsődlegesen a génaktivitás függvénye. A génaktivitást viszont számos dolog alakítja, befolyásolja a fajtasajátosságoktól, a környezeti tényezőktől, valamint a termesztéstechnológia elemei. Az antocianidinin-reduktáz (ANR) és a leukoantocianidin-reduktáz (LAR) az a két fontos enzim, amelyek a monomerek 
szintézisét szabályozzák (BoGs et al. 2005). A géneket, amelyek ezeket az enzimeket kódolják Syrah szőlőből izolálták és részletesen jellemezték.

\subsection{A bogyók fizikai paramétereinek alakulása az érés során}

A bogyóhéj keménységében az érés első fázisában növekedés tapasztalható, azonban az értékek a technológiai érettséghez közel stagnáltak vagy enyhe csökkenést mutattak (ROLLE et al. 2012b). A túlérésben lévő bogyókban azonban újra növekedés jelentkezett (ROLLE et al. 2009). A bogyóhéj keménység $\left(F_{\mathrm{sk}}\right)$ és a héj átszakításához szükséges energia $\left(\mathrm{E}_{\mathrm{sk}}\right)$ értékei alkalmasnak bizonyultak különböző fajták jellemzésére és megkülönböztetésére (Río SEGADE et al. 2008b). A héj vastagsága szintén jellemző fajtatulajdonság (LETAIEF et al. 2008a). A bogyók eddig bemutatott fizikai tulajdonságai termőhelyek elkülönítésére, jellemzésére is alkalmasak lehetnek, megjegyzendő azonban, hogy az eltérő klimatikus viszonyok és az évjárat nagyban módosítja ezeket az értékeket (LE MOIGNE et al. 2008; LETAIEF et al. 2008a; TORCHIO et al. 2010). Kijelenthető továbbá az is, hogy a bogyóhéj textúráját a termőhelyi viszonyok nagyobb mértékben befolyásolják, mint az érettség foka (MAURY et al. 2009).

Az érő bogyók egyre puhábbá és rugalmasabbá válnak, az összenyomásukhoz szükséges erő csökken (ZouID et al. 2010). Az egyre csökkenő bogyókeménység (BH) értékek jól jelzik ezt a folyamatot (MAURY et al. 2009; Río SEGADE et al. 2011b). Az eredményeket az esőzés is nagymértékben befolyásolja (LE MOIGNE et al. 2008; MAURY et al. 2009). A bogyó rugalmasságának mérése szintén alkalmasnak mutatkozott szüreti időpontok és termőhelyek elkülönítésére (Le Moigne et al. 2008; ZouID et al. 2010). Meredek termőhelyen, egy ültetvényen belül alzónákat is sikerült elkülöníteni ezzel a méréssel (Río SEGADE et al. 2011c).

A héj vastagsága, rugalmassága, keménysége jól korrelál az antocianinok kivonhatóságával (Río SEGADE et al. 2008b; Rolle et al. 2008, 2009; TORCHIO et al. 2010; Río SEGADE et al. 2011a; ROLLE et al. 2011b; RoLLE et al. 2011c). A korreláció mértéke nagyban függ a fajtatulajdonságoktól (LETAIEF et al. 2008a; LETAIEF et al. 2008b; Río SEGADE et al. 2011b; Río SEGADE et al. 2011c), környezeti, termőhelyi hatásoktól és a szüreti időponttól (Río SEGADE et al. 2011a), valamint a bogyó méretétől is (LE MOIGNE et al. 2008; MAURY et al. 2009). A magasabb $\mathrm{F}_{\mathrm{sk}}$ értékkel rendelkező, vagyis keményebb bogyók esetében kedvezőbben alakult az antocianinok kioldhatósága (ROLLE et al. 2008, 2009). A vékonyabb héjhoz egyes esetekben nagyobb kivonhatóság társult (Río SEGADE et al. 2011a). A magvak az érés során általában egyre keményebbekké válnak. 


\subsection{A fenolos érettséget befolyásoló környezeti tényezök}

Számos olyan környezeti tényező van, ami befolyásolja a flavonoidok bioszintézisét, ezáltal az érési folyamatokat. Ezek mindegyike ráadásul kölcsönhatásba is kerül egymással. Kísérlet útján tehát meglehetősen nehéz elkülönítve vizsgálni az egyes környezeti elemek hatását. Ez a jelenség egy sokváltozós egyenletként is felfogható, amelyben ha csak egyetlen paraméter is megváltozik, az már elegendő ahhoz, hogy jelentősen befolyásolja a végeredményt, jelen esetben a szőlő fenolos érettségét. Éppen ezért arra kell törekedni, hogy a rendelkezésre álló lehetőségeink szerint a lehető legtöbb környezeti tényezőt megpróbáljuk nyomon követni a vegetációs időszak alatt, és ezek együttes figyelembe vételével alakítsuk ki végső döntésünket az alkalmazandó szőlészeti, és borászati technológiára vonatkozóan.

A növényi fotoszintézis a Napból érkező fényenergia segítségével valósul meg. Így a megvilágítottság mértéke kiemelt szerepet játszik a szőlö életében. A fotoszintézis során elsődlegesen glükóz, de számos más anyagcseretermék is képződik. Ezek közé tartoznak a flavonoidok is. A növekvő fényintenzitás bizonyos mértékig elősegíti, gyorsítja az érési folyamatokat és növeli az antocianinok, valamint a tanninok koncentrációját. A tartósan megvilágított felület hőmérséklete azonban gyorsan nő és az érési folyamatok lassulása, leállása, de akár napégés is bekövetkezhet, ezért fontos az ültetvény sorainak megfelelő tájolása és szakszerü zöldmunkája, illetve a fürt tőkén való elhelyezkedése (BERGQVIST et al. 2001; SPAYD et al. 2002; DownEY et al. 2004; RISTIC et al. 2007; CHORTI et al. 2010). Az antocianinok kialakulása erősen függ a környezet hőmérsékletétől. Az alacsonyabb hőmérséklet, illetve a napközbeni és éjszakai hőmérsékletek közötti nagy különbség elösegíti az antocianinok felhalmozódását, míg a magas hőmérsékleten kialakulásuk lassabb, sőt extrém magas értékeknél $\left(>30^{\circ} \mathrm{C}\right.$ ) gátolt (HASELGROVE et al. 2000; MORI et al. 2005; YAMANE et al. 2006; KoshitA et al. 2011).

A napfény mellett a víz minden élet forrása. Tartós hiánya az életjelenségek megszünését vonja maga után. A szőlő alapjában véve egy szárazságtürő növény, a vízhiány hatásaihoz egy bizonyos mértékig alkalmazkodni képes (SCHULTZ 1996, 2003; ZSÓFI et al. 2009; ZSÓFI et al. 2011). A vízhiány ugyanakkor jelentős hatással bír a szőlő érésére, ezáltal a bor minőségére. A kutatások rámutattak arra, hogy az enyhe és a mérsékelt vízhiány a minőséget előnyösen befolyásolja. Hatására csökken a bogyóméret, ezáltal a várható termés mennyisége, nő a cukortartalom és a fenolos vegyületek koncentrációja, ugyanakkor a súlyos vízhiány már a szőlő pusztulását okozhatja. A fajták között nagymértékü eltérés mutatkozik a vízhiány iránti toleranciában (SCHULTZ 2003). A pozitív hatások két dologra vezethetőek vissza: egyfelől arra, hogy a vízhiány indukálja a flavonoidok szintéziséért felelős gének kifejeződését (CASTELLARIN 
et al. 2007a; CASTELLARIN et al. 2007b), másrészt, a csökkenő bogyóméret hatására javul a bogyó héj/hús aránya (MATTHEWs És ANDERSON 1988; KENNEDY et al. 2002; OJEDA et al. 2002; Petrie et al. 2004; RoBy et al. 2004; RoBy ÉS Matthews 2004; Bucchetti et al. 2011). Az arányt tovább javítja a bogyóhéj vastagságának növekedése (ROBY ÉS MATTHEWS 2004; PORRO et al. 2010). A héj/hús arány javulása a bogyó beltartalmának koncentrálódását vonja maga után. A vízhiány hatására a proantocianidinek polimerizáltsági foka is nő a héjban, ami bor érzékszervi tulajdonságaiban előnyös hatást hoz (OJEDA et al. 2002). A bogyó fejlődését és a fenolos komponensek bioszintézisét a vízhiány erősségén túl, fellépésének időpontja is befolyásolja (MCCARTHY 1997, 2000; OJEDA et al. 2002; OllÉ et al. 2011). A vízhiány nem befolyásolja a sejtosztódást. A bogyóméretben és tömegben bekövetkezett változást kizárólag a perikarp sejtek térfogatának csökkenése okozza (OJEDA et al. 2001). A vízhiány hatása a korai fenofázisok során jelentősebb, mivel a korán bekövetkezett bogyóméret csökkenés gyakran visszafordíthatatlan, ellentétben a később történttel, ami részben vagy egészben visszaállítható víz hatására (MCCARTHY 1997; OJEDA et al. 2001).

Ezeken túl a makroklimatikus tényezők hatása, úgymint topográfia, talaj, a terület lejtése, szélességi fok, tengerszint feletti magasság is erős befolyásoló hatással bír a fenolos érettségre nézve (MATEUS et al. 2001; MATEUS et al. 2002). A termöhely (terroir) a környezeti paraméterek összességének figyelembevételével definiálható, amely kiegészül az adott területre jellemző talajadottságokkal, szőlőművelési, borkészítési hagyományokkal, valamint, a tájat formáló, abban élő emberekkel (DELOIRE et al. 2005). Fokozottan igaz ez a megállapítás a hüvös klímájú szőlőtermesztési területeken, ahol egy jobb fekvésű, kitettségű dűlő, ugyanabban az évjáratban, jelentős minőségbeli növekedés eredményezhet, egy „rosszabb” területhez képest (VAN LEEUWEN et al. 2004; DeLOIRE et al. 2005; VAN LEEUWEN 2009). A dülő fekvése, geológiája és dőlésszöge, ugyanis jelentősen befolyásolja a napsugarak beesési szögét, ezáltal a napsütés hasznosulását, különösen a tenyészidő kezdetén és végén (HUGGETT 2006). Kiemelkedő a jelentősége tehát a megfelelő termőhely-fajta kombináció megtalálásának, hiszen a magas minőségű szőlő és bor csak így érhető el (ZSÓFI et al. 2009).

\subsection{A fenolos érettséget elösegítő szölészeti beavatkozások}

Az előző bekezdésben ismertetett eredményekből arra következtethetünk, hogy a fenolos anyagok mennyisége, összetétele egy bizonyos határon belül különböző szőlészeti beavatkozásokkal befolyásolható. Megjegyzendő ugyanakkor, hogy természet szeszélyét és az évjáratok változatosságát sajnos előre kiszámítani, így kivédeni sok esetben nem lehet. 
A vegetatív/generatív egyensúly megteremtésére való törekvéssel elősegítjük az egyenletes érést és a jobb minőséget (CORTELl et al. 2005, 2007b, 2007a; CORTELl et al. 2008; ZsÓfi et al. 2011).

Ugyancsak fontos a megfelelő tápanyaggazdálkodás. A fejlődéshez szükséges makro- és mikroelemek hiánya és túlsúlya egyaránt kerülendő (KLIEWER 1977; KELLER ÉS HRAZDINA 1998; Delgado et al. 2004).

A fürtritkítás hatását már évtizedek óta tanulmányozzák. Alkalmazása az általános minőségnövekedés mellett a fenolos érettséget is elősegíti (GUIDONI et al. 2002; PRAJITNA et al. 2007).

A korai, akár már virágzás elötti, vagy kötődés utáni levelezés hatását intenzíven vizsgálták az utóbbi évtizedekben (PONI et al. 2006; PONI et al. 2009; DiAGO et al. 2012; GATTI et al. 2012; PALLIOTTI et al. 2012; PALLIOTTI et al. 2013). Az elvégzett kezelések egyöntetüen elősegítették a szőlő fenolos érettségét. Jelentős növekedés jelentkezett az antocianin tartalomban és az összes polifenol értékekben egyaránt. A színanyagok képződésének elősegítése, olyan szőlőfajtáknál különösen fontos lehet, amelyek genetikai okokból eleve keveset termelnek (pl.: Pinot noir) (STERnAd LeMUT et al. 2011; LEE ÉS SKINKIS 2013). Meg kell jegyezni azonban, hogy a fürtzóna túlzásba vitt lelevelezésével káros, akár éppen ellenkező hatást is elérhetünk, valamint a napégés veszélye is megnő (BERGQVIST et al. 2001; SPAYD et al. 2002).

A mérsékelt vízhiány előző fejezetben ismertetett minőségnövelő hatását szabályozott hiányöntözéssel is előidézhetjük (Dos SANTOS et al. 2005; CHALMERS et al. 2010; SANTESTEBAN et al. 2011).

$\mathrm{Az}$ eddig föleg csemegeszőlökben elvégzett gyürüzés alkalmazhatóságát a borszőlőtermesztésben is vizsgálni kezdték. A gyürüzés lényege, hogy egy speciális, erre a célra kialakított ollóval a tőke fürt alatti hajtásrészén, 3-6 mm szélesen gyürű alakú bemetszést végeznek a háncsszöveten, amit aztán lehántanak. Ezzel a háncsszövet tevékenységét egy időszakra szüneteltetik. A gyürüzés feletti szárrészeken, így a fürtökben is tápanyagtorlódás lép fel, mivel az asszimiláták elszállítása a tőke gyürűzés alatti részeibe gátolt. A beavatkozás a faelemek működésére, tehát a víz és ásványi anyagszállításra nincs hatással. Az eredmények bíztatóak, ugyanis a gyürüzés hatására az érési folyamatok felgyorsulnak, illetve a színanyagtartalomban jelentős növekedés érhető el (SINGH BRAR et al. 2008; KoSHITA et al. 2011; LUKÁCSY ÉS ZANATHY 2011).

Nem szervesen a fenolos érettség témaköréhez tartozik, sokkal inkább az általános minőség javítását szolgáló technika a fürtritkítás során leszedett termésből készült bor összeházasítása a normál szüretből származóval. Ezzel a száraz és meleg évjáratok alkoholban 
túlzó, savban alacsony, magas pH-jú borainak harmóniáját segíthetjük elő (KONTOUDAKIS et al. 2011b).

\subsection{A fenolos érettség meghatározásának módszerei}

A fenolos vegyületek fontos szerepet játszanak a borok minősége, érzékszervi tulajdonságai és érlelhetősége szempontjából. Akár úgy is lehet fogalmazni, hogy a készítendő bor minősége nagyrészt már a szőlöben eldől.

Általánosan bevett gyakorlat, hogy sok termelő az érettség és a szüret időpontjának meghatározásánál csak a must cukorfokára, titrálható savtartalmára és pH értékére hagyatkozik. Ezeknek a paramétereknek az ismerete ugyan elengedhetetlen, de csak a bogyóhús érettségéről adnak tájékoztatást és nem veszik figyelembe a magvak és héj érettségét, amelyeknek elsősorban a vörösborszőlő-fajtáknál nagyon fontos szerepük van a bor összetételének, minőségének kialakításában.

A héj- és magérettség pontos megismerésének igénye ösztönzően hatott olyan új módszerek, technikák kifejlesztésére, amelyek segítségével a fenolos érettség meghatározható. Az utóbbi évtizedekben számos kutató dolgozott ezen a területen. A legelterjedtebb módszerként a szőlőbogyókból különböző oldószerek segítségével készített kivonatokat használnak. Ezek előnye, hogy használatukkal nemcsak arra kapunk választ, hogy a vizsgált fenolos vegyületek milyen mennyiségben vannak jelen a héjban és a magban, hanem arra is, hogy a borkészítés során ezek milyen mértékben oldhatóak ki. Ezek közül talán a legszélesebb körben Glories módszere terjedt el (GLORIES ÉS AUGUSTIN 1993; SAINT-CRICQ et al. 1998), amely az Anyag és módszer fejezeten belül részletesen is bemutatásra kerül. Sok kutató a Glories által kidolgozott kivonhatósági eljárást vette alapul és módosította saját elképzelései, lehetőségei szerint. Ezekről a változatokról NADAL (2010) számol be részletesen. Közös jellemzőjük, hogy kivitelezésük időigényes, jól felszerelt labort és jól képzett laboráns személyzetet igényel. Szintén kivonhatóságon alapuló, de az ehhez szükséges időt jelentősen lecsökkentő fejlesztés a spanyol Cromoenos nevü berendezés (KONTOUDAKIS et al. 2010).

A kivonhatósági mérések hátrányait figyelembe véve megnőtt az igény olyan további hordozható berendezések fejlesztésére, amelyek jóval rövidebb idő alatt, akár már a szőlőterületen megbízható eredményekkel szolgálnak. A Dualex és a Multiplex elnevezésü műszerek a bogyóhéj antocianin és flavonoid tartalmát közvetlenül tudják mérni a klorofill fluoresszencia vizsgálatával és a nyers adatok tényleges spektrummá alakításához a Fouriertranszformációt alkalmazzák (CEROVIC et al. 2008). A Dualex-szel egyéni bogyók, míg a Multiplex-szel teljes fürtök mérésére is lehetőség van. A két müszer hátránya, hogy drága és sok 
kalibrációt igényel. CELOTTI et al. (2007) olyan hordozható mini spektrofotométert (Caeleno) terveztek, amely a kézzel kipréselt bogyó héjának fenolos összetételét képes mérni. A mérés gyorsan, könnyen kivitelezhető, így reprezentatív mintavétel mellett, nagyszámú ismétlésre nyílik lehetőség. A Caeleno mérete jóval kisebb az előző két műszernél, így használata kényelmesebb a mérést végző ember számára.

A textúra elemzés egy jól kidolgozott és nagy múltra visszatekintő analitikai módszer, amelyet sokrétüen alkalmaznak az élelmiszeripar számos területén nyersanyagok és késztermékek mechanikai és fizikai karakterisztikájának meghatározására. Előnye, hogy a mérések gyorsan kivitelezhetőek alacsony üzemeltetési költségek mellett. A módszer csemegeszőlőfajtákon történő alkalmazása az 1980-as években kezdődött (ROLLE et al. 2012b). A cél a minőségi paraméterek mérésén (bogyóhús állaga, ropogóssága, a héj vastagsága, állaga stb.) keresztül a fogyasztói igények jobb kielégítése volt (ROLLE et al. 2012b). Mára bizonyítást nyert, hogy a módszer kiválóan alkalmas a borszőlő minőségének és borászati potenciáljának meghatározására is. A fenolos összetevők kémiai vizsgálata mellett az utóbbi években igény mutatkozott tehát a szőlőbogyók fizikai paramétereinek mérésére is az érés és a szüret során (Rolle et al. 2012b). Erre a célra az élelmiszeripar más területein széles körben alkalmazott textúraelemző megfelelőnek bizonyult. Használatával vizsgálható a bogyó és a mag keménysége, a héj vastagsága, valamint a bogyó deformálhatósága mellett sok más egyéb paraméter is. A magvak keménységének vizsgálata során a magvakat a textúraelemzővel megtörik és az ehhez szükséges erőt regisztrálják. De nem csak az erőhatás, hanem a deformáció közben keletkező hang akusztikai vizsgálata is alkalmas lehet a mag érettségének feltérképezésére (ROLLE et al. 2012a). Kiderült továbbá, hogy a héj keménysége és vastagsága a színanyagok kivonhatósági értékeivel jól korrelál, így lehetővé válik az optimális szüreti időpont még pontosabb meghatározása (Rolle et al. 2009; ZoUID et al. 2010; Río SEGADE et al. 2011a). A textúraelemzés az Anyag és módszer fejezetben belül bővebben is bemutatásra kerül.

Újabban a számítógépes képalkotási technikákat is segítségül hívják a magvak és a bogyók fenolos érettségének meghatározásához (RODRÍGUEZ-PULIDO et al. 2012a; RoDRíGUEZPULIDO et al. 2012b; AvILA et al. 2014).

A legfejlettebb, leginnovatívabb és egyben legdrágább módszernek azonban a multi- és hiperspektrális légi képalkotás tekinthető, amely a távérzékelés és a precíziós szőlőtermesztés egyik módszere (LAMB et al. 2004). A repülőgépről készült felvételeken megfigyelhető a lombozat mérete és a termés mennyisége, a levelek színe, sőt, a közeli infravörös tartományban készült képekkel a szőlő egyes további életjelenségeire is fény derül. Ezek alapján statisztikai összefüggéseket lehet keresni az év közbeni állapotok és a leszüretelt termés között, így például a lombozat mennyisége, színe, hőtermelése már előrevetítheti a várható termés mennyiségét és 
minőségét is. A módszerrel a termőhely heterogenitása is feltérképezhető, akár sorok, sőt egyes szőlőtőkék szintjére lebontva. A feltérképezés részletességének csak a kamera maximális felbontása szab határt.

A bogyó, a héj és a mag érzékszervi bírálata is nyújthat bizonyos támpontot a fenolos érettségre nézve (LE MOIGNE et al. 2008).

Nem elhanyagolható szempont a mintavétel reprezentativitása sem. Köztudott, hogy a szőlö érése nem egyöntetüen megy végbe, még azonos tőkén, sőt fürtön belül sem. Egyes kutatók ezért (Rolle et al. 2008, 2009; KONTOUDAKIS et al. 2011a) a leszedett bogyókat sürüségük alapján osztályozták. Ez a különbségtétel sokszor helytállóbb következtetések levonását eredményezi, mint amikor csak egy nagy átlagmintából határozzák meg az érettség fokát.

A fenolos anyagok koncentrációjának és kivonhatóságának, azaz a fenolos érettségnek a meghatározása nagyon fontos elem a megfelelő szüreti időpont kiválasztásában, de a megfelelő borkészítési technológia kiválasztásához is segítséget nyújt (GONZÁLEZ-NEVES et al. 2004b; GONZÁLEZ-NEVES et al. 2010b).

\subsection{A borászati technológia hatása a bor fenolos összetételére}

A megfelelő borászati technológia alkalmazásával, a szőlő minősége által megszabott határok között befolyásolni tudjuk a készítendö bor fenolos összetételét. Ahhoz, hogy jó döntést hozhassunk, nemcsak a feldolgozott szőlö fenolos érettségének fokát kell ismernünk, hanem azt is, hogy a különböző csoportba tartozó fenolos vegyületek a borkészítés során hogyan oldódnak ki.

Az antocianinok kioldódása már a héjontartás korai szakaszában megtörténik. Az antocián szintje a maximumot gyorsan eléri, ezután pedig mennyiségbeli csökkenés tapasztalható (SOMERS 1971; NAGEL ÉS WULF 1979). A koncentráció csökkenés több dologra vezethető vissza: oxidáció, kicsapódás, szerkezeti átalakulás (polimer pigmentek képződése). A színanyagok egy része továbbá az élesztők maradványain vagy a bogyófoszlányok szilárd részein is adszorbeálódhat (CHEYNIER et al. 2006). Az is megfigyelhető, hogy az erjedés első fázisában főként a héjból oldódnak ki a fenolos anyagok, de ahogy növekszik az alkohol koncentrációja, a hőmérséklet, valamint a héjontartás ideje, úgy nő a magvakból a borba kerülő tanninok részaránya, ami a fenolos anyagokat tartalmazó sejtek javuló áteresztőképességével és/vagy felrepedésével hozható összefüggésbe (PRIEUR et al. 1994; SOUQUET et al. 1996; CANALS et al. 2005). Az erjedés befejeződése utáni elnyújtott héjontartás esetén a magból származó tanninok válnak dominánssá és a polimer pigmentek aránya is megnő (GONZÁLEZ-MANZANO et al. 2004; 
CheYNier et al. 2006; DEL LlaUdy et al. 2008; CASASSA et al. 2013). Ezeket a jelenségeket figyelembe véve, számos olyan borászati technika áll rendelkezésünkre, amellyel sikeresen növelhetjük a borok fenolos anyagainak mennyiségét (SACCHI et al. 2005). Ezek közé tartozik a melegítéses vörösborkészítés (mindent figyelembe véve a bor minőségét alapvetően rontja), a cefrefagyasztás (pl.: száraz jéggel), valamint a pektolitikus enzimkészítmények használata (BAutista-Ortín et al. 2005; Romero-CASCAles et al. 2008; DuCASSE et al. 2010).

Egy további, franciául „saignée”-nak nevezett eljárás során a színlé egy részét már az erjedés elején elválasztják, ezáltal az erjedő cefre térfogatát csökkentik, így a cefréből kioldódó anyagok koncentrációja a visszamaradó lében megnő. A leválasztott színlevet általában rozé készítésére használják (SACCHI et al. 2005).

Az erjedés előtti hidegáztatás az utóbbi években került előtérbe. Az eljárást az antocianinok és aromaanyagok mennyiségének növelése érdekében alkalmazzák, azonban számos egymásnak ellentmondó publikáció jelent meg a témában. Egyes esetekben a kezelésnek nem, vagy csak rövid ideig tartó hatása volt, de olykor csökkenést is kimutattak a színanyagok mennyiségében (SACCHI et al. 2005; ÁlVAREZ et al. 2006; GÓMEZ-MíGUEZ et al. 2007; GILMuNOZ et al. 2009; BUSSE-VALVERDE et al. 2010; GONZÁLEZ-NEVES et al. 2010a; GORDILLO et al. 2010; ORTEGA-HeRAS et al. 2012; GONZÁlEZ-NEVES et al. 2013). Ezekböl azt szürhetjük le, hogy a beavatkozás sikeressége nagymértékben fajta- és évjáratfüggö, ráadásul a hütés gyorsasága és milyensége sem elhanyagolható, hiszen a szárazjéggel végzett hütés sokkal magasabb hatásfokú és gyorsabb is, mint a tartályok külső hütőköpenyével történő hőfokcsökkentés.

A szénsavas maceráció alkalmazása is több egymásnak eltérő eredményt hozott. Egyes szerzők csökkenést tapasztaltak az antocianinok ill. az összes polifenol mennyiségében (SuN et al. 2001; GÓMEZ-MíGUEZ ÉS HEREDIA 2004), míg mások növekedést (LŐRINCZ et al. 1998).

Ugyancsak nem egyértelmü a különböző élesztőtörzsek használatának és a kénezés adagjának a hatása, ami szintén az alkalmazott szőlőfajta szerepét mutatja.

A törkölykalap rendszeres, naponta történő többszöri fellazítása és alámerítése akár csömöszöléssel, akár körfejtéssel jótékony hatással van a kioldódási folyamatkora (SACCHI et al. 2005). Ezeken túl a szőlő feldolgozásának, bogyózásának-zúzásának hatásfoka (CERPACALDERON ÉS KENNEDY 2008), valamint a kocsánnyal együtt vagy külön történő erjesztés (SUN et al. 2001) is meghatározza a születő borban a tanninok mennyiségét. A kocsánnyal együtt történő erjesztés során, fontos megvizsgálni az érettségét és a kontaktidő hosszát, hiszen nem körültekintő alkalmazás során többet árthatunk, mint használunk. 
DOI: $10.14267 /$ phd.2015023

\section{ANYAG ÉS MÓDSZER}

\subsection{A Nagy-Eged-hegy jellemzése}

A Kis-Eged-hegy oldalában talált Vitis hungarica And. néven ismert ősszőlő levelének 30 millió éves, megkövült lenyomata a bizonyíték arra, hogy az Egri Borvidéken a mai Vitis vinifera L. (bortermő szőlő) őse már nagyon korai időkben jelen volt. Ezt figyelembe véve nem meglepő az évszázados hagyományokkal rendelkező egedi szőlőmüvelés megléte. SUGÁR (1981) azt írja, hogy „Egerben erősségre, színre (!), aromára a legjobb minőségü borok az Egeden termett szőlőből voltak szüretelhetők.” A terület sokáig egri érsekségi birtok volt. A virágzó szölökultúrát a filoxéra törte meg az 1890-es évek végén. A termöhely müvelésével az 1970-es években hagytak fel végleg, mivel a nagyüzemi termelési célokat nem tudta kifizetődően kiszolgálni. A Nagy-Eged „felélesztésére” a 2000-es évek elején kerülhetett újra sor. A termőhely nagy múltját és talán még ennél is fényesebb jövőjét szem előtt tartva az ültetvények megtervezése, a megfelelő fajták és alanyok kiválasztása, eltelepítése a legmagasabb szintü szakmai kívánalmaknak megfelelően vette kezdetét. A Nagy-Eged két főbb dűlőre oszlik. Az alsóbb részt Nagy-Eged-dűlőnek, a felsőbb régiókban fekvőt Nagy-Eged-hegynek hívjuk.

A terület több szempontból is különleges. Vékony termőrétegü talaja mészkő alapkőzeten alakult ki, szemben az Egri Borvidék csaknem egészét alkotó riolittufával. Ez a mészkő alap a talaj felszínén is sok helyen előbukkan nagyméretű kövek formájában (16. ábra). Ezek a felszíni kövek a Nap sugarait szétszórják, tovább melegítve környezetüket. Ezen túlmenően képesek a nappali hőt elraktározni, majd éjjel kisugározni, ami fokozottan elősegíti a szőlő érési folyamatait. Az érési folyamtokra a domborzat, a kitettség és a lejtőszög is hatással van. A nagymértékü lejtés miatt a napsugarak majdnem merölegesen érkeznek be a déli oldalon. Ezen hatások együttesen eredményezik azt, hogy a hegynek igen egyedi, a borvidékinél melegebb klímája van. A szőlőültetvények közel 500 méteres tengerszint feletti magasságig megtalálhatók, ezzel ezek Magyarország legmagasabban fekvő szőlőtermő területei. 
DOI: $10.14267 /$ phd.2015023

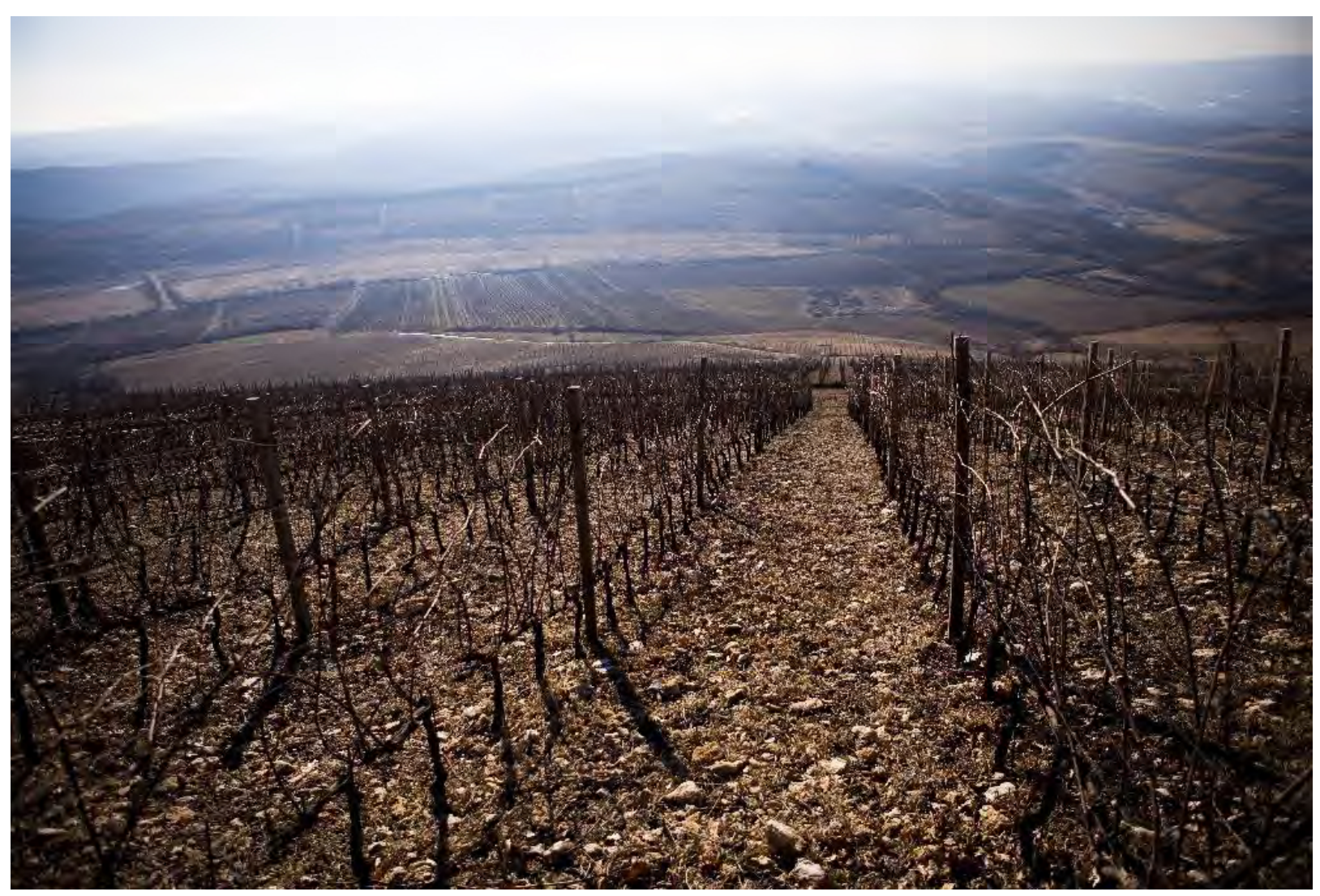

16. ábra - A nagy-egedi terroir (Fotó: Szmodits Balázs)

Az 537 méter magas Nagy-Eged a Bükk hegység része. Eger városától észak-keletre fekszik. Fő tömegét szürke, triászkori mészkő alkotja. Területét 40 millió éve még a Pannontenger borította. A tengerből finom, sárgásfehér üledék, mészmárga rakódott a triászkori mészkőre. Ez az ún. nummulitesz-mész ma a hegy legjellemzőbb kőzete. Nevét az eocénban jellemző, mára már kihalt egysejtü állatfajról, a Nummulitesekről kapta, de számos egyéb egykor élt állat és növény lenyomata is megtalálható a mészköveken (BÁNYAI et al. 2012). 
DOI: $10.14267 /$ phd.2015023

\subsection{A kísérleti parcella jellemzése}

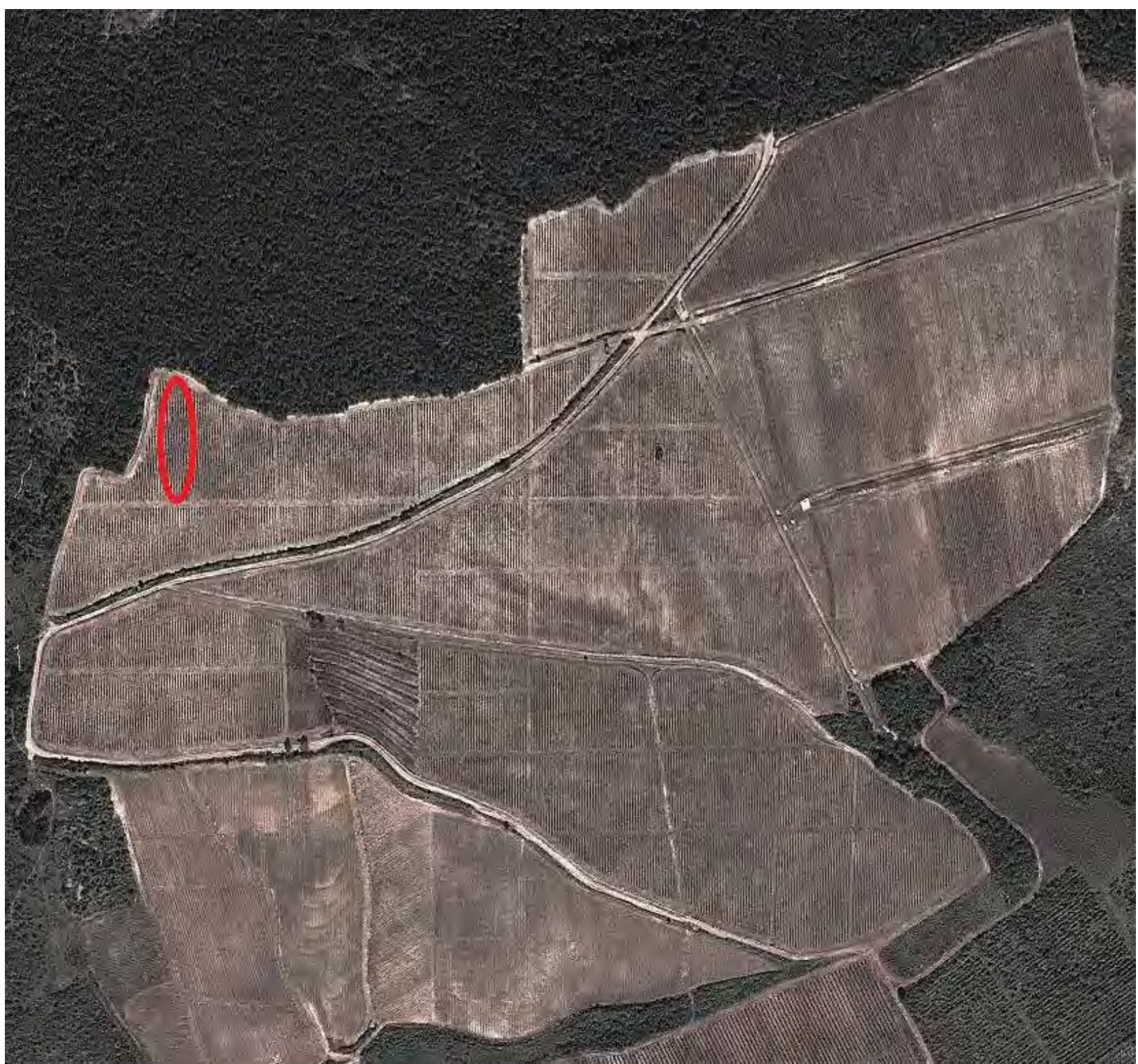

17. ábra - A kísérlet helyszíne a Nagy-Eged-hegy dűlőn belül (Forrás: Google Earth)

A kísérletet a Gróf Buttler Borászati Zrt. által művelt Nagy-Eged-hegy dűlőben állítottam be (északi szélesség 4755'31.84"; nyugati hosszúság 20²4'42.32", tengerszint feletti magasság: $430 \mathrm{~m}$ ) (17. ábra). Az ültetvényt 2003-ban telepítették. Sor és tőtávolsága 2,4x0,8 m. A müvelésmód alacsony egy karú Royat-kordon, $60 \mathrm{~cm}$-es törzsmagassággal. A metszés során, kordonkaronként, mindhárom évben (2011., 2012., 2013.) 4 termőalapot, ezeken pedig 1-1 kétrügyes csapot hagytunk meg, így a meghagyott világos rügyek száma 8 darab volt tőkénként (18. ábra). 


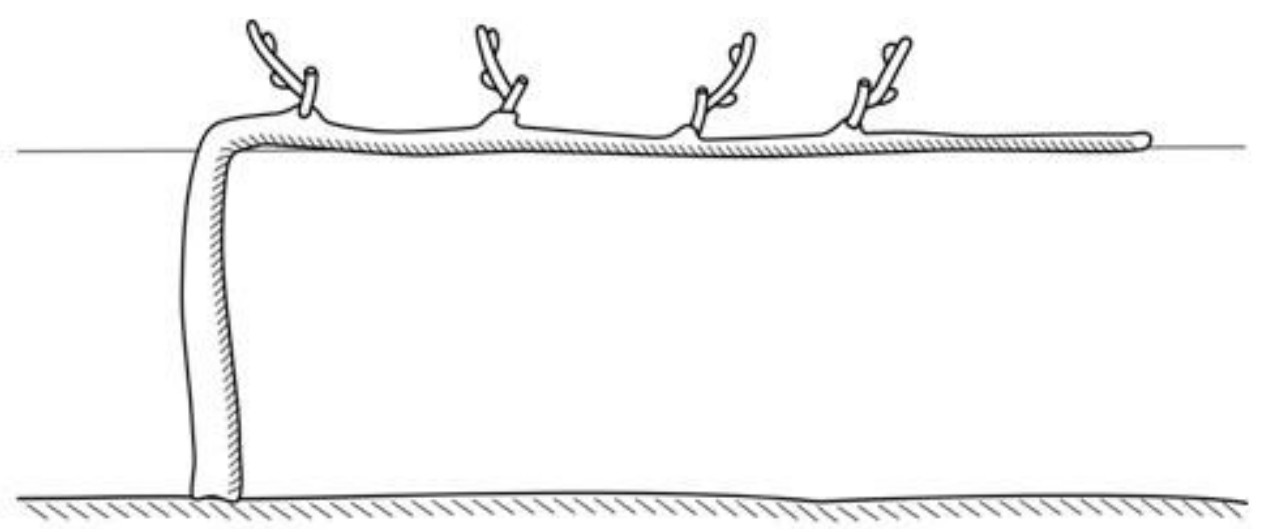

18. ábra - Royat-kordon müvelésmód (LŐRINCZ ÉS BARÓCSI 2010)

A dülő egésze, így az ültetvény is déli kitettségü, lejtőviszonya változatos: 8\%-tól 35\%-ig terjedő lejtésfokkal. Az eső nagy hányada a termőhelyi viszonyokból és a talaj csekély víztartóképességéből adódóan gyorsan „leszalad” a hegyről, ami talajeróziót idéz elő. Az ültetvényben jelentős vízhiányból adódó stressz is kialakulhat bizonyos években. Mindezek alapján megállapítható, hogy a terület nem tekinthető homogénnek, az egyes pontjai között nagy eltérés figyelhető meg.

Az extrém termőhelyi viszonyok miatt a kísérlet első évében (2011) szükség volt a vizsgálat céljára kijelölendő terület homogenitásának vizsgálatára. A feladat megoldását a hiperspektrális távérzékelés segítette. A dủlő egészét egy speciális kamerával felszerelt mezőgazdasági repülőgép repülte be. A célom az volt, hogy olyan kísérleti helyet jelöljek ki, amely területi adottságaiban egységesnek tekinthető, így az adott szőlötőke területi elhelyezkedése a kísérleti eredményeket érdemben nem befolyásolja. Ezáltal biztosítható az, hogy a vizsgálatok során várható különbségek, egyértelműen a kezelés hatására lesznek visszavezethetőek. A kamera által rögzített adatokból megalkottuk a dűlő közeli infravörös tartományban (NIR) készült térképét, valamint a 800 nm-es és 670 nm-es sávokból kiszámítottuk a vegetációs indexet, más néven NDVI-t (Normalized Difference Vegetation Index) is (PeTtorelli 2013). A térképek a mellékletben találhatók meg. Az NDVI egy dimenzió nélküli mérőszám, amely a vegetációs aktivitást fejezi ki. Az NDVI értékét a növényzet közeli infravörös (NIR) és a látható vörös (RED) sugárzási tartományban visszavert intenzitások különbségének és összegének hányadosa adja, mivel a zöld klorofillt tartalmazó növényekre jellemző, hogy az ebben a tartományban található fényt nagymértékben visszaverik. Az adott területről visszaverődő látható vörös és közeli infravörös fény mennyiségének alapján osztályozhatjuk a terület fotoszintetikus kapacitását, mivel az NDVI korrelál a területet takaró növényfelület fajlagos klorofill tartalmával. A nullás érték a növényzet hiányát jelöli, míg az 1-hez közeli számok sürü erdővel borított területre utalnak. A piros ellipszissel jelölt terület 
legalacsonyabban fekvő blokkjában az NDVI értékei: min.: 0,14, max.: 0,53, átlag: 0,33, szórás: 0,66. A legfelsőbb blokkra jellemzőbb értékek pedig: min.: 0,04, max.: 0,57, átlag: 0,27, szórás: 0,67. A kapott adatok alapján megállapítható, hogy a kijelölt terület a kísérlet célkitüzéseinek megvalósításához megfelel.

\subsection{Az ültetvény tápanyag ellátottságának vizsgálata}

Az ültetvény levél- és talajanalízisére 2011. augusztusában, a kísérlet kezdő évében került sor. A talajvizsgálathoz a kísérletre kijelölt terület három pontjáról vételeztem átlagmintát, míg a levélvizsgálathoz 100 levelet gyüjtöttem be. Ezek alapján az alábbi megállapításokra jutottam. A termőréteg sekély, erősen meszes jellegü, a kőhányad pedig igen jelentős. A területen kialakult rendzina talaj humuszos „A” szintje 25-40 cm mély, kedvező (4,63-6,73 \%) humusztartalommal. A magas humusztartalmat a közeli erdősáv indokolhatja, ahonnan az esővíz általi erózió során a termőréteg az ültetvénybe „folyik”. A réteg kémhatása gyengén bázikus (vizes pH értéke: 7,77,9). Alatta a „B” szint 20-50 cm mély, csökkent (1,15-3,73 \%) humusztartalmú; növekvő, gyengén bázikus - bázikus kémhatású (vizes pH értéke 7,9-8,1). Alatta a feltárási 80-120 cm-es mélységig húzódó „C” szint kémhatása jellemzően bázikus - erősen bázikus (vizes pH értéke: 8,0-8,6 közötti). A talaj fizikai félesége vályog, jellemzően agyagos vályog ( $\mathrm{K}_{\mathrm{A}}$ értéke: 39-48 közötti). Szénsavas meszet az összes vizsgált minta tartalmazott változatos mennyiségben (28,645,5\%). A fiziológiás mésztartalom értéke 23,1-37,9 \% között változik. A vízoldható összes sótartalom értéke megfelelő, 0,01-0,12 \% közötti. Szódalúgosság nem, illetve nyomokban mutatható ki. A mintákban változatos mennyiségben (10-40 \%) kövek találhatók. A mállott alapkőzetben, több esetben 60-80 cm mélységben 25-30 cm átmérőjü kövek mennyisége meghaladja az 50\%-ot. A talaj felvehető és tartalék tápanyagának mennyiségét, tápanyag szolgáltató képességét EUF analízissel határoztuk meg. A felső réteg kedvező nitrogénszolgáltatású, alatta megfelelö-közepes. Összességében alacsony mind a könnyen felvehető (P-I, K-I), mind a tartalék (P-II, K-II) foszfor és kálium mennyisége ezzel együtt szolgáltató képessége. A vizsgált minták kalciummal telítettek, emellett közepes magnéziumszolgáltatás és megfelelő mikroelem-tartalom a jellemző. A levélanalízis eredményei alapján az ültetvény nitrogéntartalma alacsony $(2,25 \mathrm{~m} / \mathrm{m} \%)$, foszfortartalma optimális $(0,22$ $\mathrm{m} / \mathrm{m} \%)$, káliumtartalma alacsony $(0,62 \mathrm{~m} / \mathrm{m} \%)$, kalciumtartalma magas $(4,47 \mathrm{~m} / \mathrm{m} \%)$, magnéziumtartalma optimális $(0,29 \mathrm{~m} / \mathrm{m} \%)$, vastartalma optimális $(115 \mathrm{mg} / \mathrm{kg})$, mangántartalma optimális $(90,6 \mathrm{mg} / \mathrm{kg})$, cinktartalma optimális $(25,1 \mathrm{mg} / \mathrm{kg})$. 


\subsection{Alkalmazott termesztéstechnológia}

Az ültetvényben mechanikai talajművelés az extrém termőhelyi körülményekből adódóan egyáltalán nem folyik. A sorközök és a sorok aljának gyommentesítését egyaránt kézi munkával, damilos fükaszával végzik. A tápanyag utánpótlását, a terület nitrátérzékenysége miatt kizárólag gondosan megválasztott lombtrágyával, előzetes levélanalízis elvégzése alapján, évente 4-5 alkalommal végezik. Az ültetvény a telepítés évében, 2003-ban kapott érett istállótrágyát. Ennek kijuttatása egyedileg történt, minden egyes tőke ültetőgödrébe külön-külön. Az ültetvény csekély vegetatív és generatív növekedéséből adódóan minden vizsgált évben csak mérsékelt zöldmunkára volt szükség. A gondosan beállított kis rügyterhelés miatt, további terméskorlátozás alkalmazása nem volt indokolt. A növényvédelmi munkákat a birtok egészén elsősorban a kontakt szerekre alapozzák, emiatt több és rövidebb permetezési forduló tartása szükséges. A rovarölő és gyomirtó szereket teljesen mellőzik. Felszívódó szerek használatára csak nagyon indokolt esetben kerülhet sor.

\subsection{A vizsgált szölöfajta (Syrah) jellemzése}

A Syrah (Európában, Észak- és Dél-Amerikában) vagy Shiraz (Ausztráliában, DélAfrikában) az egyik legelterjedtebb és legnépszerübb szőlőfajta a világon. Termőterülete az utóbbi évtizedekben ugrásszerűen nőtt világszerte. Az érdeklődés és a telepítési kedv hazánkban azonban csak a 2000-es évek elején indult meg iránta. Összterülete 2011-ben 177 hektár volt. Ez az érték Magyarország 69,715 hektáron elterülő összes szőlöültetvényét figyelembe véve, meglehetősen kis arány. (Forrás: Hegyközségek Nemzeti Tanácsa, www.hnt.hu)

Eredete: A Syrah őshonos francia fajtának tekintendő és egy természetes kereszteződés eredménye. Öshazája és fö termőhelye a Rhône folyó vidéke. A szülők, anyai részről a Mondeuse blanche, apai oldalról pedig a Dureza nevű szőlőfajta (BowERS et al. 2000; VOUILLAMOZ ÉS GRANDO 2006).

Ampelográfiai jellemzői: Középerős növekedésű. Hajtása félig felálló. Vesszői középvastagok, ízközei hosszúak, barnás rózsaszín árnyalatúak. Vitorlája erősen gyapjas, teljesen nyitott. Levele (19. ábra) középnagy, ötkaréjú, felszíne kiterített, felülete gyengén hólyagos. Vállöble kissé nyitott, esetenként érrel határolt, oldalöble nyitott. A levél széle csipkés-fürészes rövid-közepes fogakkal, az erek töve kissé lilás árnyalatú. Fonákja közepesen gyapjas szőrözöttségű. 
Fürtje (20. ábra) középnagy, hengeres, esetenként vállas, közepesen tömött. Bogyói kicsik, elliptikus alakúak, színük sötétkék, héja közepesen vastag, húsa puha, lédús.

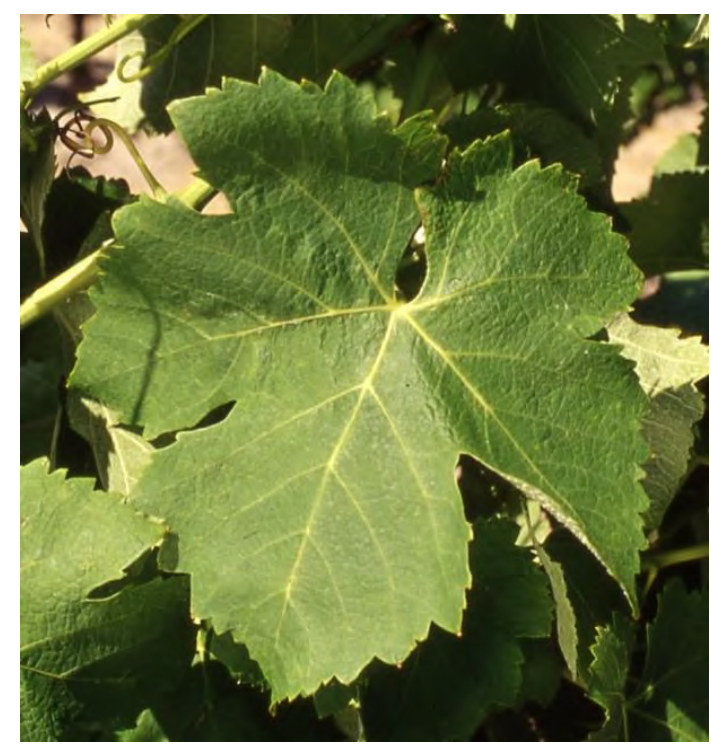

19. ábra - A Syrah levele

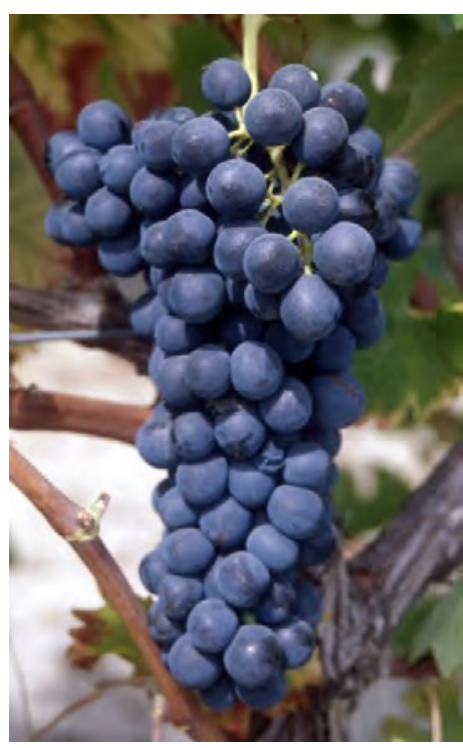

20. ábra - A Syrah termése

A képek forrása: http://plantgrape.plantnet-project.org/cepage/Syrah\%20N

Termesztési értéke: Termőképessége jó, alsó rügyei is termékenyek, ezért elegendő rövidcsapos metszéssel termeszteni. Szálvesszős metszéssel könnyen túlterhelhető. Hosszú vesszőket nevel, amelyek a tavaszi, szeles időben eltörhetnek. Eredményesen termeszthető alacsony kordonon (pl.: Royat-kordon), de Guyot müvelésmóddal is. Zöldmunka-igénye közepes. A Syrah nagyon érzékeny a klorózisra, emiatt a magas aktív mésztartalmú talajokhoz rosszul alkalmazkodik. Ilyen termőhelyeken nagyon fontos a helyes alany megválasztása. Az atkák gyakran károsítják. Peronoszpórára közepesnél jobban, lisztharmatra közepesen fogékony. Szürkerothadásra közepesen érzékeny. A fürtfonnyadás jelensége előfordul, főként előrehaladott érési állapotban. A Syrah az aszályra, vízhiányra kevésbé érzékeny, szárazságtürő fajtaként jellemezhető (SCHUltz 1996, 2003). Nagy meleg- és hőigényü fajta, ezért rügyei érzékenyek a fagyra. Későn fakad és későn is érik be. Az optimális szüreti időpont meglehetősen rövid. Magyarországon általában október elején, közepén szüretelhető. A Nemzeti Fajtajegyzékbe, mint telepítésre engedélyezett fajta 2008-ban került fel. Államilag elismert, bejelentett klónjai még nincsenek. A fajta jó színanyag és tanningyüjtő képességgel rendelkezik. Megfelelő klímaviszonyok között magas cukorfokkal és mérsékelt savtartalommal érik be. Borának cukormentes extrakt-, polifenol-, valamint színanyag-tartalma egyaránt magas. A megfelelő fenolos érettséget elért alapanyagból készült borai hosszú ideig, barrique érlelésre is alkalmasak. A Syrah-ból nagyon fajtajelleges, füszeres (borsos), gyümölcsaromákban gazdag borok készíthetőek (WoOD et al. 2008). 
A kisérlet során használt klón jellemzése: A kísérlet a Syrah, ENTAV-INRA ${ }^{\circledR}$ 877-es, Franciaországban szelektált klónján állítottam be. Ez az egyik legnépszerübb és legnagyobb felületen telepített klón. Sikerességét számos előnyös tulajdonságának köszönheti. Kiemelkedő minőségre képes. Az alapfajtához viszonyítva nagyon alacsony termőképességgel, kisebb, lazább fürtökkel, kisebb bogyókkal rendelkezik. Magasabb cukor-, sav-, antocianin- és polifenoltartalommal képes beérni. Borának aromaintenzitása, teltsége, gazdagsága, hosszúsága, érlelhetősége szembetünő. (Forrás: http://plantgrape.plantnet-project.org/cepage/Syrah\%20N)

\subsection{A kezeléshez felhasznált lombtrágya, a LalVigne ${ }^{\circledR}$ Mature}

A kísérletben a Lallemand cég által kifejlesztett LalVigne ${ }^{\circledR}$ Mature (továbbiakban: LM) (szabadalmaztatás alatt álló technológia: WO/2014/024039) nevü lombtrágyájának hatását vizsgáltam. A szer csak és kizárólag természetes összetevőket tartalmaz, veszélytelen és garantáltan GMO mentes. A termék fő alkotóelemei közé tartoznak a Lallemand által, speciálisan erre a célra szelektált inaktív élesztők (Saccharomyces cerevisiae) és ezek kivonatai. A készítmény biostimulátorként alkalmazható és a flavonoidok, valamint egyéb más másodlagos anyagcseretermékek bioszintézisét segíti elő (DUO et al. 2014; LiSSARRAGUE et al. 2014). A sprayt két alkalommal szükséges kijuttatni. Alkalmazásának első időpontja a zsendülés elején javasolt, amikor a bogyóknak még csak körülbelül 5\%-a színeződött. A második permetezést, az első után, 12-14 nap múlva kell időzíteni. Az első permetezésre 2012-ben augusztus 7-én, a másodikra augusztus 19-én került sor. 2013-ban az első kijuttatás augusztus 8-án, a második augusztus 21-én történt meg. Az ajánlott dózis $1 \mathrm{~kg} / \mathrm{ha}$. A kísérlet során bekevert dózist ez alapján határoztam meg területarányra vonatkoztatva. A kijuttatás motoros háti permetezőgéppel történt. A permetszert csapvízben oldottam fel, tapadásfokozót nem adtam hozzá. A termék jó oldhatósága miatt kismértékü kevertetés is elég volt ahhoz, hogy homogén elegyet kapjak. A permetlevet a teljes lombfelületre, a fürtzónát is beleértve jutattam ki, úgy hogy a levelek és a fürtök minden oldalára jusson belőle. 
DOI: $10.14267 /$ phd.2015023

\subsection{A kísérlet beállítása Syrah fajtán}

2011-ben, a kísérlet kezdő évében három sort, a rákövetkezőkben, 2012-ben és 2013-ban a meglévő három mellé újabb hármat jelöltem ki. Egy sor három blokkot, míg egy blokk 25-29 darab tökét tartalmazott. A 2011-es évben csak kontroll növényeket vizsgáltam, a következő években, 2012-ben és 2013-ban viszont már a lombtrágyával kezelteket is tanulmányoztam. A 2011-es év a kísérleti parcella megismerésének jegyében telt. A kontroll, vagy lombtrágyázatlan (továbbiakban: C) és kezelt, vagy lombtrágyázott (továbbiakban: LM) sorok között két, pufferként szolgáló sort hagytam. A blokkok kijelölésénél a táblaszéleket, a szegélyhatás elkerülése végett kihagytam (21. ábra).

\begin{tabular}{|c|c|c|c|c|c|c|}
\hline \multicolumn{3}{|c|}{ Kontroll (C) sorok } & & \multicolumn{3}{|c|}{ Kezelt (LM) sorok } \\
\hline 1. sor & 2. sor & 3. sor & $2 \mathrm{db}$ puffer sor & 4. sor & 5. sor & 6. sor \\
\hline $\begin{array}{c}\text { 1. szüret } \\
1 . \\
\text { ismétlés }\end{array}$ & $\begin{array}{c}\text { 2. szüret } \\
1 . \\
\text { ismétlés }\end{array}$ & $\begin{array}{c}\text { 3. szüret } \\
1 . \\
\text { ismétlés }\end{array}$ & & $\begin{array}{c}\text { 2. szüret } \\
1 . \\
\text { ismétlés }\end{array}$ & $\begin{array}{c}\text { 3. szüret } \\
1 . \\
\text { ismétlés }\end{array}$ & $\begin{array}{c}\text { 1. szüret } \\
1 . \\
\text { ismétlés }\end{array}$ \\
\hline $\begin{array}{c}\text { 3. szüret } \\
2 . \\
\text { ismétlés }\end{array}$ & $\begin{array}{c}\text { 1. szüret } \\
2 . \\
\text { ismétlés }\end{array}$ & $\begin{array}{c}\text { 2. szüret } \\
2 . \\
\text { ismétlés }\end{array}$ & & $\begin{array}{c}\text { 1. szüret } \\
2 . \\
\text { ismétlés }\end{array}$ & $\begin{array}{l}\text { 2. szüret } \\
2 . \\
\text { ismétlés }\end{array}$ & $\begin{array}{c}\text { 3. szüret } \\
2 . \\
\text { ismétlés }\end{array}$ \\
\hline $\begin{array}{c}\text { 2. szüret } \\
3 . \\
\text { ismétlés }\end{array}$ & $\begin{array}{c}\text { 3. szüret } \\
3 . \\
\text { ismétlés }\end{array}$ & $\begin{array}{c}\text { 1. szüret } \\
3 . \\
\text { ismétlés }\end{array}$ & & $\begin{array}{c}\text { 3. szüret } \\
3 . \\
\text { ismétlés }\end{array}$ & $\begin{array}{c}\text { 1. szüret } \\
3 . \\
\text { ismétlés }\end{array}$ & $\begin{array}{l}\text { 2. szüret } \\
3 . \\
\text { ismétlés }\end{array}$ \\
\hline & & & & & & \\
\hline
\end{tabular}

21. ábra - A kísérlet elrendezése

\subsection{Mintavétel}

A szőlő mintázása mindhárom évjáratban, öt-öt időpontban (2011-ben 2, 3, 4, 6, és 8 héttel, 2012-ben és 2013-ban 2, 3, 4, 5, 7 héttel a zsendülés után) történt meg. Az utolsó három időpontban mikrovinifikációs bortételek is készültek, mind a kontroll, mind a kezelt blokkokból háromszoros ismétlésben. A kísérleti borokhoz az egyes blokkokban megtermett összes szőlőt, nagyságrendileg 20-20 kg-ot szüreteltem le kezelésenként és szüreti időpontonként. A leszedett szőlőmennyiséget külön-külön dolgoztam fel és a bogyózás-zúzás után nyert cefréket szintén külön erjesztettem. Az egy blokkba tartozó tökék számát tehát úgy határoztam meg, hogy egy blokk termése elegendő alapanyagot szolgáltasson 10 liter bor készítéséhez.

A szőlő érettségi fokának meghatározásához $1 \mathrm{~kg}$, véletlenszerüen megszedett mintát gyüjtöttem be időpontonként, mindhárom évben. A fürtök végéről, közepéről, válláról, árnyékos és napos oldaláról egyaránt válogattam. A minták fürtrészleteket tartalmaztak, amiket 
hűtőtáskában, a lehető legrövidebb időn belül szállítottam be a KRF Szőlészeti és Borászati Kutatóintézetének egri laboratóriumába.

A megszedett 1 kilogrammnyi mintát, az elvégzendő mérésekhez több alcsoportra osztottam. 100-100 darab véletlenszerủen kiválasztott bogyót használtam fel a tömegmérésekhez kezelésenként és ismétlésenként. Ezek kipréselt mustjából határoztam meg a cukor- és savtartalmat, valamint a $\mathrm{pH}$ értéket.

A textúraelemzéshez kezelésenként kétszer 50 bogyót különítettem el. Egy bogyó ennél a mérésnél egy ismétlést jelent, éppen ezért törekedni kellett a teljesen ép és egészséges bogyók kocsánnyal együtt történő levágására. A textúraelemzést 2011-ben három, 2012-ben és 2013-ban öt-öt időpontban végeztem el.

A fenolos érettség meghatározásához (Glories módszer) 150 db, kocsányáról leválasztott bogyót különítettem el. Ezt kettéosztottam a pH 1-es és pH 3,4-es oldószerek számára. A mérést háromszor ismételtem. Egy ismétlés $25 \mathrm{db}$ bogyót tartalmazott. A színanyagok kivonhatóságának vizsgálatát 2011-ben három, 2012-ben és 2013-ban öt-öt időpontban végeztem el.

\subsection{Vizsgált paraméterek}

\subsubsection{Meteorológiai mérések}

A csapadékra, hőmérsékletre, napsütéses órák számára, valamint a teljes és hasznos hőösszegre vonatkozó adatokat automata meteorológia mérőállomás gyüjtötte (Boreas Kft., Érd, Magyarország). Az állomás a kísérlet helyszínétől kb. 300 méterre található.

A fürtzónában, az érés hónapjaiban (augusztus, szeptember, október) uralkodó hőmérsékletet Tinytag Plus 2 TGP-4500-as típusú mini adatrögzítővel regisztráltam (Gemini Data Loggers Ltd., Chichester, Egyesült Királyság).

\subsubsection{Az ültetvény termésmennyiségének vizsgálata}

Az egyedi tőketerhelést, fürtszámot és fürtátlagtömeget, minden évjáratban, a második szüreti időpontban mértem meg. Az eredményeket 15 tőke átlagában mutatom be. Az átlagos bogyótömeget (100 db bogyóból számítva) minden kezelésnél és időpontban feljegyeztem.

\subsubsection{A mustok és a borok analízise}

A redukáló cukortartalmat Rebelein módszerével határoztam meg (SCHMITT 2005). A titrálható savtartalmat $\mathrm{NaOH}-$ os titrálással, a pH értékét Thermo Scientific Orion 3-Star típusú 
pH mérővel, az alkoholtartalmat lepárlással, az extrakttartalmat piknométeres módszerrel mértem (OIV 2014).

A fenolos összetevők vizsgálata spektrofotométerrel történt meg (UVmini-1240 CE UVVIS, Shimadzu, Japan). Az antocianintartalmat a RIBÉREAU-GAYON ÉS STONESTREET (1965) leírtak alapján határoztam meg. Az összes polifenoltartalom vizsgálatára Folin-Ciocalteu módszerét használtam (SINGLETON ÉS ROSSI 1965), az eredményeket galluszsav egyenértékben közlöm (GAE mg/l). A leukoantocianin mennyiségét vas (II)-szulfátot tartalmazó sósav-butanol, 40:60 arányú elegyével történő melegítés után (FLANZY et al. 1969), míg a katechintartalmat vanilines színreakción alapuló eljárással vizsgáltam (AMERINE ÉS OUGH 1980). A borok színintenzitásának $\left(\mathrm{A}_{420}+\mathrm{A}_{520}\right)$ és színárnyalatának $\left(\mathrm{A}_{420} / \mathrm{A}_{520}\right)$ megállapításához GLORIES (1984) iránymutatásait vettem alapul. Minden mérést háromszoros ismétlésben végeztem el.

A bogyóminták és a mustok analízisét egyaránt a KRF Szőlészeti és Borászati Kutatóintézetének laboratóriumában, míg a borok teljes körü vizsgálatát a Budapesti Corvinus Egyetem Borászati Tanszékén végeztük el.

\subsubsection{Tannin indexek}

A borok zselatin és sósav $(\mathrm{HCl})$ indexei egyaránt meghatározásra kerültek. Erről a két mérési módszerről PÁsTI (2002) részleteiben számol be.

\subsubsection{A fenolos érettség mérése Glories módszerével}

A szőlő fenolos érettségének, a bogyók érettségi indexének nyomon követéséhez Glories módszerét használtam, amely a színanyagok kivonhatóságán alapszik (GLORIES ÉS AUGUSTIN 1993; SAINT-CRICQ et al. 1998). A kivonhatóság hatásfokának megállapításához két, egymástól eltérö összetételü és pH értékủ pufferoldat elkészítése szükséges. A méréshez kezelésenként 25-25 db bogyót használtam fel három ismétlésben. A bogyókat, kocsányukról leválasztva $25 \mathrm{ml}$ pH 1-es és $25 \mathrm{ml} \mathrm{pH} \mathrm{3,4-es} \mathrm{pufferoldatba} \mathrm{helyeztem.} \mathrm{(Megjegyzés:} \mathrm{az} \mathrm{eredeti} \mathrm{módszer} \mathrm{3,2-es}$ pH-val dolgozik) Az oldat kémhatását az Egri Borvidékre általánosságban jellemző magasabban alakuló pH értékek figyelembevételével emeltük meg.

A pufferoldatokba helyezett mintákat konyhai turmixgéppel a legmagasabb fokozaton homogenizáltam, fél percen keresztül. Az így kapott elegyet 4 óra hosszát állni hagytam és óránként egyszer üvegbottal megkevertem. A mintákat a macerációs idő letelte után 15 percen keresztül centrifugáltam tízezres fordulatszámon. A tiszta mintákat ezután hütőbe tettem, és másnap készítettem elő a spektrofotometriás mérésekhez (UVmini-1240 CE UV-VIS, Shimadzu, Japan). A pH 1-es oldat az összes elérhető színanyagot kioldja, míg a 3,4-es a borkészítés során 
fennálló kémhatást hivatott modellezni, mintegy „szimulálja” a héjontartás alatt meglévő viszonyokat és csak a ténylegesen kioldható színanyagokat oldja ki. A kapott fényelnyelési értékekből számítható ki az érési index, amely az antocianinok kivonhatóságáról ad információkat. Az adatokat százalékokban kapjuk meg. Az alkalmazott képlet alapján a kisebb értékek a ,,jobbak”, mivel ez az érték azt mutatja meg, hogy mennyi színanyag marad vissza a bogyó héjában. Másképpen fogalmazva kifejezi az összes antocianin és a kivonható antocianinok mennyisége közötti eltérést. Minél kisebbek tehát ezek az értékek annál jobb a kivonhatóság, annál nagyobb a fenolos érettség foka (CAGNASSO et al. 2008).

\section{A pufferoldatok elkészitése}

A pH1-es oldat $0,4 \mathrm{M}$ oxálsavat tartalmaz $50,7 \mathrm{~g} / 1$ mennyiségben.

A pH3,4-es oldathoz az alábbi vegyszereket használtam fel, 1 liter desztillált vízben feloldva:

- $23 \mathrm{ml} 85 \% \mathrm{H}_{3} \mathrm{PO}_{4}$ (foszforsav)

- 27,6 g NaH${ }_{2} \mathrm{PO}_{4}$ x $\mathrm{H}_{2} \mathrm{O}$ (mononátrium-foszfát)

- $17,8 \mathrm{~g} \mathrm{Na}_{2} \mathrm{HPO}_{4} \times \mathrm{H}_{2} \mathrm{O}$ (dinátrium-foszfát)

Az így elkészített oldat 100 ml-ét $1 \mathrm{M} \mathrm{NaOH-val} \mathrm{3,4} \mathrm{pH-ra} \mathrm{állítottam} \mathrm{be.} \mathrm{A} \mathrm{titrálás} \mathrm{közbeni}$ fogyást mérve a szükséges $1 \mathrm{M} \mathrm{NaOH}$ mennyisége könnyen kiszámítható 1 literre vonatkoztatva.

\section{A lecentrifugált, hütőböl kivett minták elökészitése a spektrofotometriás méréshez}

$1 \mathrm{ml}$, 1-es pH-jú pufferoldattal kezelt mintához (továbbiakban: A1) hozzáadtam $1 \mathrm{ml} 0,1 \%$ sósavas etanolt és $20 \mathrm{ml}$ 2\%-os sósavat, majd összeráztam. Ebből az oldatból 2-2 ml-t vettem ki. Az egyikhez 0,8 ml 15\%-os Na-biszulfitot (pH1 NaHS), míg a másikhoz 0,8 ml desztillált vizet (pH1 dvíz) adtam. Mindkettőt óvatosan összeráztam, majd 20 perc elteltével $520 \mathrm{~nm}$-en, $1 \mathrm{~cm}$-es küvettában desztillált vízzel szemben spektrofotométerrel megmértem.

$$
\text { A1 = pH1 dvíz - pH1 NaHS }
$$

$1 \mathrm{ml}, 3,4$-es pH-jú pufferoldattal kezelt mintához (továbbiakban: A3,4) hozzáadtam $1 \mathrm{ml}$ 0,1\% sósavas etanolt és $20 \mathrm{ml}$ 2\%-os sósavat, majd összeráztam. Ebből az oldatból 2-2 ml-t vettem ki. Az egyikhez 0,8 ml 15\%-os Na-biszulfitot (pH3,4 NaHS), míg a másikhoz 0,8 ml desztillált vizet (pH3,4 dvíz) adtam. Mindkettőt óvatosan összeráztam, majd 20 perc elteltével 520 nm-en, $1 \mathrm{~cm}$-es küvettában desztillált vízzel szemben spektrofotométerrel megmértem.

$$
\text { A3.4 = pH3,4 dvíz - pH3,4 NaHS }
$$


Végezetül az A280-as érték meghatározásához 0,5 ml-t vettem ki a 3,4 pH-jú pufferoldattal kezelt mintából. Ehhez 9,5 ml tiszta 3,4 pH pufferoldatot adtam, majd összeráztam. Ezután várakozás nélkül mértem a fényelnyelést $280 \mathrm{~nm}$-en, $2 \mathrm{~mm}$-es küvettában (5-szörös hígítás) a pH 3,4-es pufferoldattal szemben.

A számitásokhoz az alábbi képleteket használtam:

$$
\begin{gathered}
\text { EA\% (kivonhatóság) }=[(\mathrm{A} 1-\mathrm{A} 3.4) / \mathrm{A} 1] \times 100 \\
\mathrm{SM} \%(\text { magérettség })=[(\mathrm{A} 280-((\mathrm{A} 3.4 / 1000) \times 40)) / \mathrm{A} 280] \times 100
\end{gathered}
$$

Az A1-es és az A3,4-es abszorbancia értékekböl kalibrációs görbe segítségével az összes és a kivonható antocianinok mennyiségét is kiszámoltam $\mathrm{mg} / \mathrm{l}-\mathrm{ben}$. Minden mérést háromszoros ismétlésben végeztem el.

\subsubsection{A bogyók textúraelemzése}

A bogyók fizikai tulajdonságainak méréséhez a TA.XTplus típusú textúraelemzőt (Stable Micro System, Surrey, Egyesült Királyság) használtam HDP 90-es platformmal és $30 \mathrm{~kg}$-os maximális terheléssel (22. ábra).

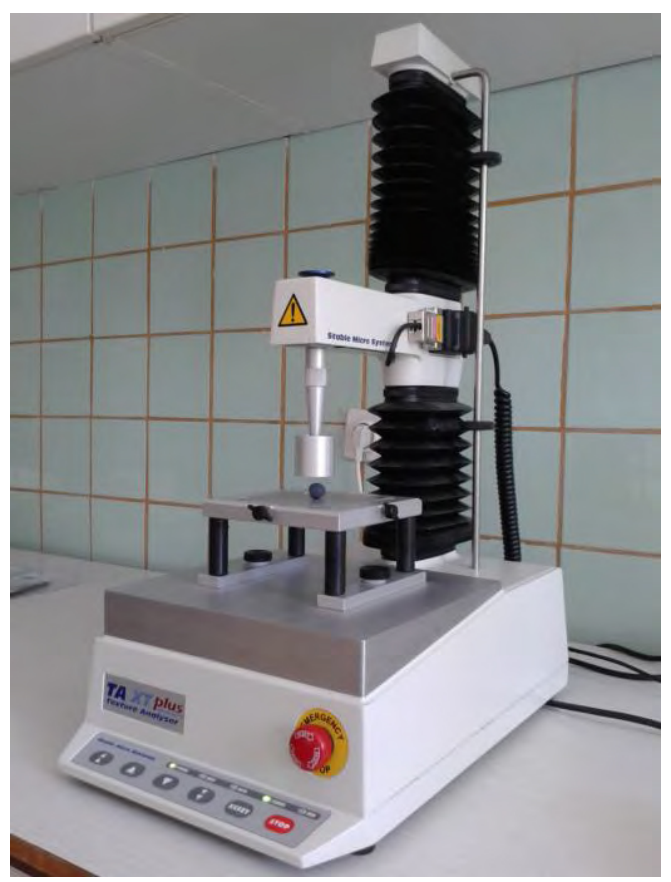

22. ábra - A textúraelemző müszer (saját felvétel) 


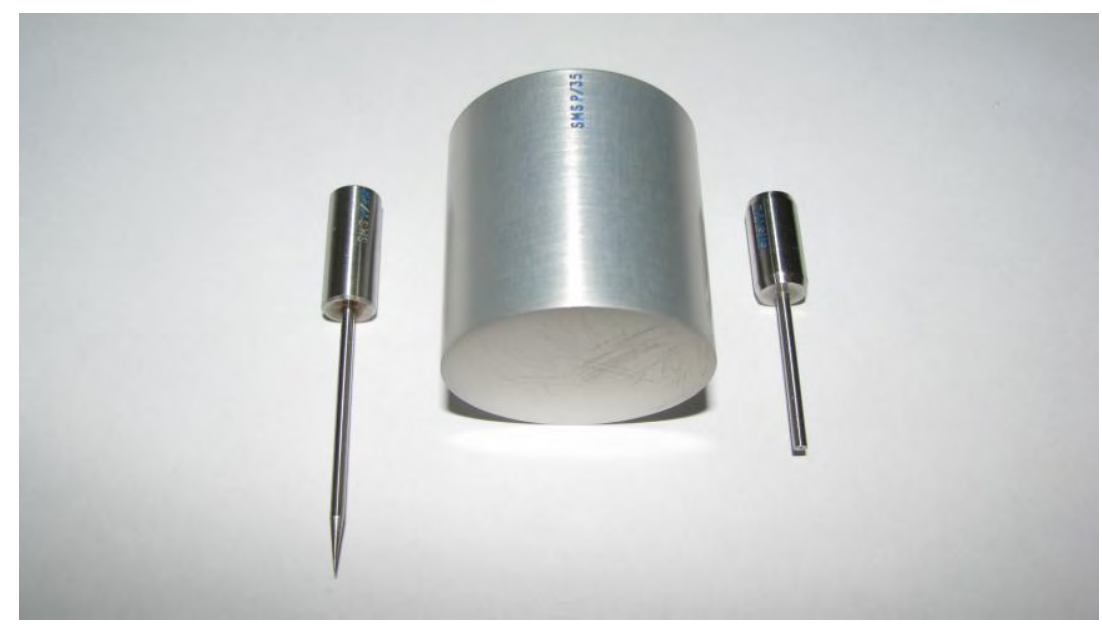

23. ábra - A textúraelemzőre felszerelhető szondák (saját felvétel)

Balról jobba:

$\mathrm{P} / 2 \mathrm{~N}$ típusú tü, a bogyóhéj keménységének vizsgálatához

P/35 típusú henger, a bogyókeménység (dupla összenyomásos teszt) és a magkeménység méréséhez

P/2 típusú laposvégü tü, a héjvastagság meghatározásához

Az adatok kiértékelését az Exponent program 6.1.4.0-ás verziójával végeztem el. A tesztek elvégzése során a program a bogyók reogrammját valós időben rajzolja ki a csatlakoztatott számítógépen (24. ábra).
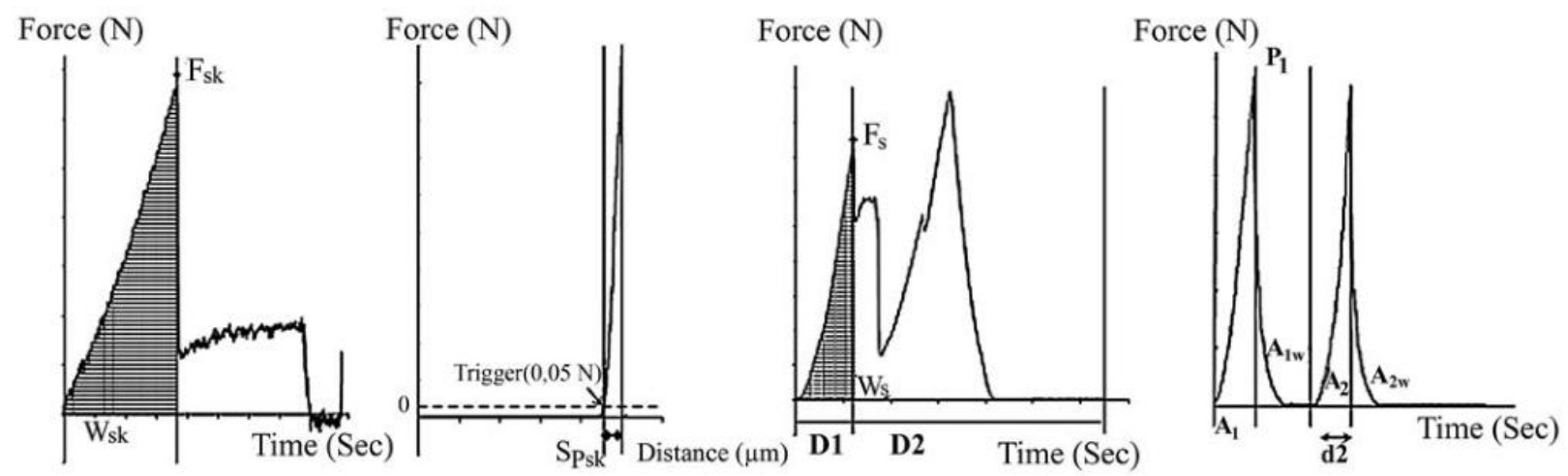

24. ábra - A bogyóhéj keménységéhez, a vastagságához, a magkeménységhez és a bogyókeménységhez tartozó tipikus reogrammok vázlatosan (balról jobbra)

(LETAIEF et al. 2008a)

$\mathrm{F}_{\mathrm{sk}}$ : a bogyóhéj átszakításához szükséges maximális erő = első csúcs; $\mathrm{E}_{\mathrm{sk}}$ : a héj Young modulusa $=$ az $\mathrm{F}_{\mathrm{sk}} \mathrm{t}$ az origóval összekötő egyenes meredekségével; $\mathrm{W}_{\mathrm{sk}}$ : a bogyóhéj átszakításához szükséges munka = a görbe alatti satírozott terület; $\mathrm{Sp}_{\mathrm{sk}}$ : A héj vastagsága egyenlő a szonda által megtett úttal a héj felső része és a tárgylemez között; $\mathrm{F}_{\mathrm{s}}$ : a mag megtöréséhez szükséges erő = 
első csúcs; $\mathrm{E}_{\mathrm{s}}$ : a mag Young modulusa $=\mathrm{az} \mathrm{F}_{\mathrm{s}} \mathrm{t}$ az origóval összekötő egyenes meredekségével; $\mathrm{W}_{\mathrm{s}}$ : a mag megtöréséhez szükséges munka = a görbe alatti satírozott terület; D1: törési távolság, azaz a szonda által megtett út hossza; A1, A1W, A2, A2W: az összenyomáshoz és felengedéshez tartozó görbe alatti területek az első és a második nyomás során; P1: az első összenyomatás csúcsa; d2: a szonda által megtett út a második összenyomás alatt. Bogyókeménység $(\mathrm{BH}, \mathrm{N})=\mathrm{a}$ P1-hez tartozó erō; Bogyókohézió $(\mathrm{BCo},-)=(\mathrm{A} 2+\mathrm{A} 2 \mathrm{~W}) /(\mathrm{A} 1+\mathrm{A} 1 \mathrm{~W})$; Bogyónyúlósság (BG, $\mathrm{N})=\mathrm{BH}^{*} \mathrm{BCo} ;$ Bogyóruganyosság $(\mathrm{BS}, \mathrm{mm})=\mathrm{d} 2 ;$ Bogyórághatóság $(\mathrm{BCh}, \mathrm{mJ})=$ $\mathrm{BH}^{*} \mathrm{BCo} * \mathrm{BS}$; Bogyórugalmasság $(\mathrm{BR},-)=(\mathrm{A} 1 \mathrm{~W} / \mathrm{A} 1)$ (LETAIEF et al. 2008a)

Megjegyzés: A mérési paraméterek megnevezése után, a zárójelen belül adom meg a hozzájuk tartozó rövidítést és mértékegységet.

A müszer beállítása és a mérési körülmények a LETAIEF et al. (2008b) és ZsÓFI et al. (2014) által megadottak szerint voltak összhangban. Minden paraméter mérése előtt sor került a kar magasságának, sebességének, maximális nyomóerejének a kalibrálására, valamint a megfelelő szonda felhelyezésére (23. ábra és 1. táblázat). 
DOI: $10.14267 /$ phd.2015023

\begin{tabular}{|c|c|c|c|c|}
\hline Mérés & Szonda & $\begin{array}{c}\text { Szonda } \\
\text { sebessége }\end{array}$ & Összenyomás & Mért fizikai paraméterek \\
\hline $\begin{array}{c}\text { Bogyóhéj } \\
\text { keménysége }\end{array}$ & tü $(\mathrm{P} / 2 \mathrm{~N})$ & $1 \mathrm{~mm} / \mathrm{s}$ & $3 \mathrm{~mm}$ & $\begin{array}{c}\mathbf{F}_{\mathbf{s k}}=\text { bogyóhéj keménység }(\mathrm{N}) \\
\mathbf{E}_{\mathbf{s k}}=\text { Young modulus }(\mathrm{N} / \mathrm{mm}) \\
\text { (az anyag tengelyirányú } \\
\text { deformációval szembeni } \\
\text { ellenállása = az anyag } \\
\text { keménysége az alkalmazott } \\
\text { nyomás/súly ellenében } \\
\mathbf{W}_{\mathbf{s k}}=\text { átszakítási munka }(\mathrm{mJ})\end{array}$ \\
\hline $\begin{array}{c}\text { Bogyóhéj } \\
\text { vastagsága }\end{array}$ & $\begin{array}{c}\mathrm{P} / 2 \\
\varnothing 2 \mathrm{~mm}\end{array}$ & $0,2 \mathrm{~mm} / \mathrm{s}$ & nincs & $\mathbf{S} \mathbf{p}_{\mathbf{s k}}=$ bogyóhéj vastagság $(\mathrm{mm})$ \\
\hline $\begin{array}{c}\text { Mag } \\
\text { keménysége }\end{array}$ & $\begin{array}{c}\mathrm{P} / 35 \\
\varnothing 35 \\
\mathrm{~mm}\end{array}$ & $1 \mathrm{~mm} / \mathrm{s}$ & $50 \%$ & $\begin{array}{c}\mathbf{F}_{\mathbf{s}}=\text { magkeménység }(\mathrm{N}) \\
\mathbf{E}_{\mathbf{s}}=\text { Young modulus }(\mathrm{N} / \mathrm{mm}) \\
\mathbf{W}_{\mathbf{s}}=\text { megtörési munka }(\mathrm{mJ})\end{array}$ \\
\hline \multirow{4}{*}{$\begin{array}{c}\text { Bogyó } \\
\text { keménység } \\
\text { (dupla } \\
\text { összenyomásos } \\
\text { teszt) }\end{array}$} & \multirow{4}{*}{$\begin{array}{c}\mathrm{P} / 35 \\
\varnothing 35 \mathrm{~mm}\end{array}$} & \multirow{4}{*}{$1 \mathrm{~mm} / \mathrm{s}$} & \multirow{4}{*}{$25 \%$} & $\begin{array}{c}\text { Bogyókeménység }(\mathrm{BH}, \mathrm{N}) \\
\text { BH = a kívánt deformációhoz } \\
\text { szükséges erő } \\
\text { Bogyókohézió }(\mathrm{BCo},-) \\
\text { BCo = a bogyót összetartó erők } \\
\text { nagysága }\end{array}$ \\
\hline & & & & $\begin{array}{c}\text { Bogyónyúlósság (BG, N) } \\
\text { BG = annak az erőnek a } \\
\text { nagysága, amely ahhoz } \\
\text { szükséges, hogy egy félkemény } \\
\text { anyagot, jelen esetben a } \\
\text { szőlőbogyót lenyelésre } \\
\text { alkalmassá tegyünk }\end{array}$ \\
\hline & & & & $\begin{array}{l}\text { Bogyórághatóság (BCh, mJ) } \\
\text { BCh = annak az energiának a } \\
\text { nagysága, amely ahhoz } \\
\text { szükséges, hogy egy szilárd } \\
\text { anyagot lenyelésre alkalmas } \\
\text { állapotba hozzunk }\end{array}$ \\
\hline & & & & $\begin{array}{c}\text { Bogyórugalmasság (BR, -) } \\
\text { BR = a bogyó azon tulajdonsága, } \\
\text { hogy milyen mértékben képes a } \\
\text { deformáció után eredeti alakját } \\
\text { visszanyerni }\end{array}$ \\
\hline
\end{tabular}

1. táblázat - A textúraelemzővel elvégezhető mérések LETAIEF et al. (2008a) nyomán 
A bogyókeménység $(\mathrm{BH}, \mathrm{N})$ meghatározása a henger alakú $\mathrm{P} / 35$-ös szondával történt. Ehhez a méréshez a bogyókat kocsányukkal együtt kisméretű ollóval vágtam le a fürtről. A mérést nagyban befolyásolja a bogyó mérete, így a helyes mintavételre, a megközelítőleg azonos méretü, leginkább jellemző bogyók kiválasztására nagy figyelmet kell fordítani. A teljesen ép és egészséges bogyómintákat oldalsó fekvésben mértem, úgy hogy a kocsány vízszintesen feküdt a platformon (LETAIEF et al. 2008a; MAURY et al. 2009). A müszer kétszer nyomja össze a bogyókat átmérőjük 25\%-áig (Río SEGADE et al. 2011b; Río SEGADE et al. 2011c). A két nyomás között 2 másodperc telik el (LETAIEF et al. 2008a). A vizsgálat során a bogyó megroppanhat. Ebben az esetben új bogyó mérésére van szükség. A bogyó keménységén túl, további öt, származtatott fizikai paramétert olvashatunk le az erö/terhelés görbéről (1. táblázat) (LETAIEF et al. 2008a).

A bogyóhéj keménységének vizsgálatához a bogyókat kocsányukkal együtt helyeztem a $\mathrm{P} / 2 \mathrm{~N}$-es típusú tü alá. A szúrás addig tartott, amíg a tủ a bogyó héján átjutott. A méréssel a bogyóhéj három paraméterét tudtam megállapítani, az erőt, amely ahhoz szükséges, hogy a tü átjusson a héjon $\left(F_{s k}, N\right)$, az eközben elvégzett munkát $\left(W_{\text {sk }}, m J\right)$ és a Young modulust $\left(E_{s k}, N / m m\right)$.

A magkeménység vizsgálatakor a müszerre a bogyókeménységnél $(\mathrm{BH})$ használt hengert $(\mathrm{P} / 35)$ helyeztem fel. A henger a magvakat teljesen megtörte. A magvak keménységének meghatározása során szintén három, a héjkeménységnél is vizsgált paramétert jegyeztem fel. Ezek a mag megtöréséhez szükséges erö $\left(\mathrm{F}_{\mathrm{s}}, \mathrm{N}\right)$, az eközben elvégzett munka $\left(\mathrm{W}_{\mathrm{s}}, \mathrm{mJ}\right)$ és a Young modulus $\left(\mathrm{E}_{\mathrm{s}}, \mathrm{N} / \mathrm{mm}\right)$ voltak.

A bogyóhéj vastagságának méréshez egy P/2-es $2 \mathrm{~mm}$ átmérőjü lapos végü, kör alapterületü szondát használtam. A bogyó oldalsó részéröl körülbelül $0,25 \mathrm{~cm}^{2}$ héjat távolítottam el kézzel, lándzsatű segítségével. A héjdarabka lefejtése után, a rátapadó bogyóhúst papírtörlő kendővel teljes mértékben eltávolítottam. A szonda alá történő behelyezésnél a gyürődést, felkunkorodást el kell elkerülni. Ellenkező esetben előfordulhat az úgynevezett „farok effektus” (25. ábra).

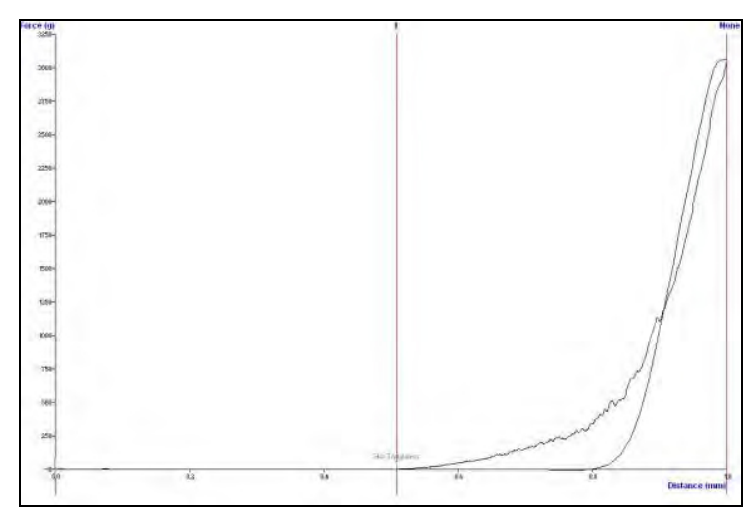

25. ábra - A „farok effektus” mérési hibát jelent a héjvastagság meghatározása során (saját felvétel) 
Ha ilyet tapasztaltam, a mérést meg kellett ismételnem. A héj vastagsága egyenlő a szonda által megtett úttal a héj felső része és a tárgylemez között.

\subsubsection{A borok rezveratroltartalmának meghatározása HPLC-vel}

A rezveratroltartalom mérésénél KÁLLAY ÉS TÖRÖK (1997) módszere szerint jártunk el. A borok szürés után közvetlenül injektálhatóak voltak a HPLC készülékbe. A minták szüréséhez 0,45 $\mu \mathrm{m}$ pórusátmérőjü Sartorius membránszürőt használtunk. A rezveratrolmeghatározás izokratikus módon történt. Az alkalmazott eluens acetonitril : metanol : víz, $5: 5: 90$ arányú keveréke volt. A méréshez a HP Series 1050-es gyártmányú HPLC készülékét használtuk, LiChrospher ${ }^{\circledR}$ 100, CN $5 \mu \mathrm{m}$ oszloppal (Merck, Németország). A detektor szintén HP Series 1050-es gyártmányú volt. A folyadékáramot $2 \mathrm{ml} /$ percre, a hőmérsékletet $30^{\circ} \mathrm{C}$-ra, a hullámhosszot pedig 306 nm-re állítottuk be. A transz-rezveratrol (99\%-os tisztaságú) sztenderdet a Sigma-Aldrich-től (Németország) vásároltuk meg. A transz-piceid sztenderdet a San Michele all'Adige Kutató és Innovációs Központból szereztük be. A cisz-izomereket a transz-izomerek UV besugárzásával állítottuk elő (SATO et al. 1997). A méréseket a Budapesti Corvinus Egyetem Borászati Tanszékének budafoki laboratóriumában végeztük el.

\subsubsection{Kísérleti borkészítés}

20-20 kg szőlőt szüreteltem le kézzel mindkét kezelésből, mindhárom szüreti időpontban, mindhárom ismétlésben. A szőlőt kisméretü műanyagládákban szállítottam be a KRF Szőlészeti és Borászati Kutatóintézetének kísérleti borfeldolgozó üzemébe a lehető legrövidebb időn belül. A termést bogyóztuk-zúztuk, majd a cefrét lekéneztük. Literenként $1 \mathrm{ml}$ 5\%-os kénessav törzsoldatot adtam a cefréhez, amely $5 \mathrm{~g} / \mathrm{hl}$ cefrekénezésnek felel meg. Ezután mind a kontroll, mind a lombtrágyával kezelt szőlöből készített cefrét három egyenlő részre osztottam és mủanyag hordókban rögtön a pincébe szállítottam. A pincében uralkodó állandó $13^{\circ} \mathrm{C}-\mathrm{os}$ hőmérséklet biztosította az erjedés kezdetétől a végéig szükséges hütést. A fajélesztős beoltásra 24 órás hidegmaceráció után került sor. Ennek során 20 g/hl dózisú Uvaferm VN (Lallemand Inc.) élesztôt és $30 \mathrm{~g} / \mathrm{hl}$ dózisú Uvavital tápsót (Lallemand Inc.) adagoltam minden tételhez. A maceráció egységesen 23 napig tartott. A törkölykalapot a héjontartás ideje alatt napi kétszer csömöszöltem. A főerjedés végén, $10 \mathrm{mg} / 1$ dózisban, Uvaferm Alpha (Lallemand Inc.) almasavbontó baktériumkultúrával is beoltottam mindegyik tételt. Az erjesztés és a héjontartás egyaránt a mủanyag hordókban ment végbe. A préselést 23 nap letelte után, 30 liter ürtartalmú, hidraulikus elven müködő membránpréssel végeztük, 1,5 bar maximális nyomáson. A színlétől a préslevet nem választottuk külön. Miután az almasavbontás végbement a borokat lefejtettük. Az 
újborokat a szükséges laboratóriumi mérések és érzékszervi bírálatok elvégzéséig kénezés nélkül, 10 literes ürtartalmú üvegballonokban tároltam (26. ábra). A borok háromszoros ismétlésben és mindhárom évben ugyanezzel a borászati technológiával készültek el.

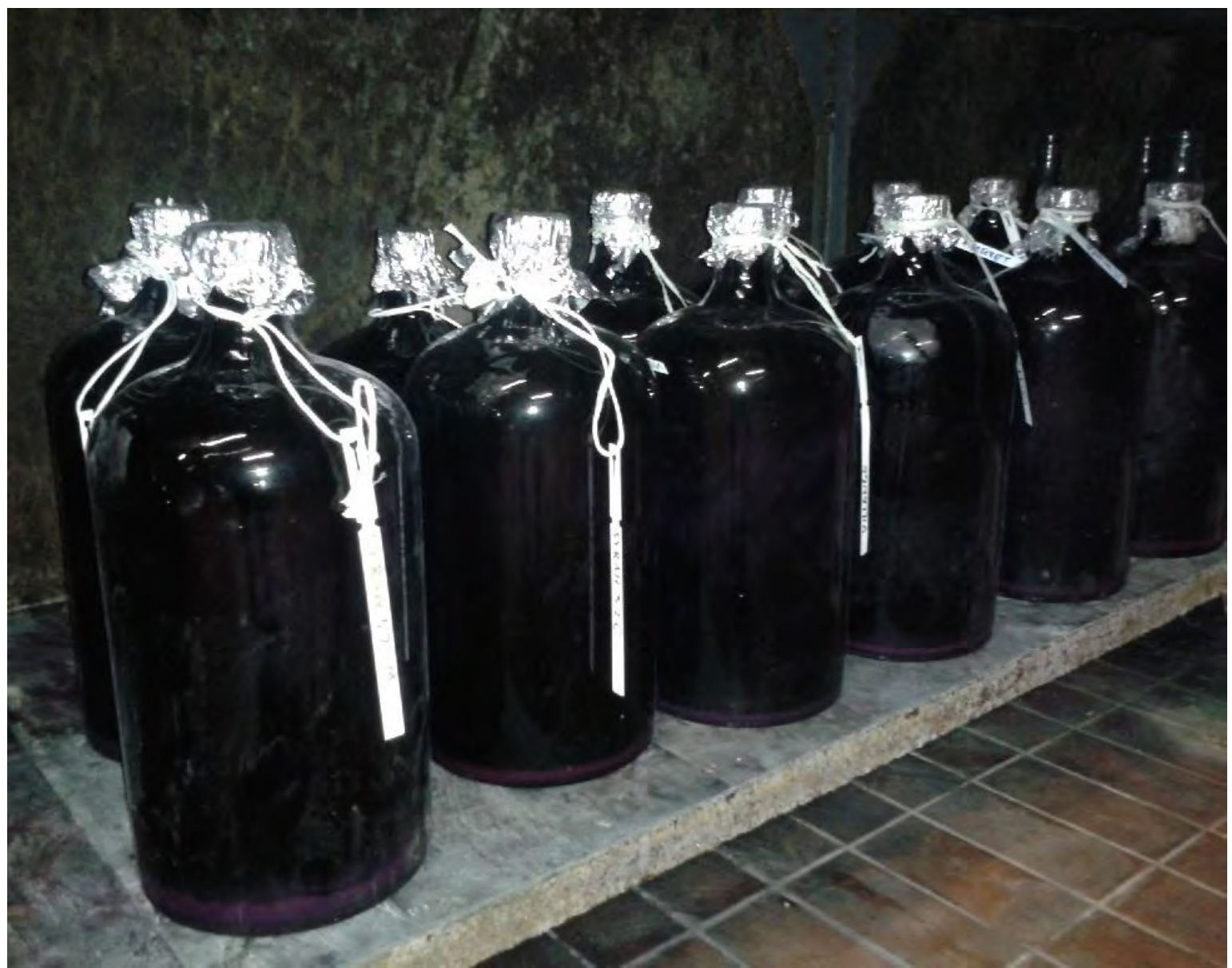

26. ábra - Mikrovinifikációs borkészítés (saját felvétel)

\subsubsection{A borok érzékszervi bírálata}

Az elkészült borok érzékszervi tulajdonságait profilanalízissel hasonlítottuk össze. Azért esett a választás erre a módszerre, mert így a borok illat- és ízösszetevőinek alaposabb, mélyebb elemzésére is lehetőség nyílt, szemben az egyszerü pontozásos módszerekkel, amelyek csak az összbenyomásról tájékoztatnak. A kóstolókon mindhárom évjáratban 17, a szőlész-borász szakmában dolgozó bíráló vett részt. A bírálaton 13 kiválasztott paramétert (megjelenés; illatintenzitás; gyümölcsös jelleg illatban; füszeres jelleg illatban; gyümölcsös jelleg ízben; füszeres jelleg ízben; fajtakarakter; savérzet; teltségérzet, testesség; tanninok mennyisége; húzósság; ízhosszúság; összbenyomás, harmónia) kellett egy tízes skálán értékelni. A különböző tulajdonságokra adott pontszámok átlagai minden tétel esetében egy pókháló diagramon jelennek meg. Az átlagtól leginkább eltérő, alsó és felső szélsőértéket adó bíráló pontszámát nem vettem 
figyelembe. Az ábra középpontja a 0 érték, a kör külső ívén a maximálisan adható 10-es található. A tengelyek jelentik az értékelt tulajdonságokat és a rajtuk elhelyezkedő pontszámokat összekötve rajzolódik ki a bor ,,profilja”. Ezzel a rendszerrel elsősorban mennyiségi paraméterek vizsgálatára van lehetőség. Minél jobban érződik az adott jegy, annál nagyobb pontszámot kap. Két tulajdonság esetében (savérzet és húzósság) a skála fordított. Itt az alacsonyabb értékek a jobbak, hiszen ezek a bor minőségére negatívan ható tulajdonságok. Összességében megállapítható, hogy minél nagyobb felületet fed le a diagram, annál jobb minőségü, harmonikusabb bort kóstoltunk.

\subsection{Statisztikai kiértékelés}

A statisztikai analízisek elvégzése során az IBM SPSS 20 (IBM Corp., Armonk, NY, USA) programot használtuk. A kísérlet eredményeit többváltozós varianciaanalízissel (MANOVA) hasonlítottuk össze. A három faktor a következő volt a 2012-es és a 2013-as évjárat során: évjárathatás, kezelés (C, LM), szüreti időpont. Az egyes változók kitüntetett hatása mellett azok interakcióját is elemeztük. A 2011-es évet teljesen külön kezeltük. Mivel ebben az évben lombtrágyás kezelést még nem alkalmaztam, így csak a különböző szüreti időpontokból adódó eltérések összehasonlítására volt lehetőség. A szóráshomogenitás-vizsgálat Levene teszttel történt. Amennyiben a szüreti időpontok hatása szignifikáns volt, úgy Tukey vagy Games-Howell post hoc tesztet alkalmaztunk, attól függően, hogy a szóráshomogenitás fennállt, vagy sem. A különböző latin betükkel jelölt értékek, a kezelések közötti szignifikáns különbséget jelölik azonos évben és azonos szüreti időpontban. A különböző görög betűkkel jelölt értékek, a szüreti időpontok közötti szignifikáns különbséget jelölik azonos évben és azonos kezelésen belül. A * az évjáratok között szignifikáns különbséget jelöli, azonos kezelésen és szüreti időponton belül. Az összehasonlításokat $\mathrm{p}=0,05$ szinten végeztük. 


\section{CÉLKITÜZÉS}

A kísérletre kiválasztott terület már ismertetett extrém adottságai miatt, gyakran és nagymértékben jelentkezik a vízhiány, valamint a talajerózió hatása (ZSÓFI et al. 2009; ZSÓFI et al. 2011; NAGY et al. 2012). Ezek következtében a vegetatív növekedés gátolt, a termés mennyisége alacsony. Emiatt, az irodalmi áttekintésben már bemutatott, a fenolos érést elősegítő szőlészeti beavatkozások (lelevelezés, fürtritkítás, gyürüzés stb.) ebben az ültetvényben nem, vagy csak korlátozottan alkalmazhatóak.

A bevezetésben kifejtett, részben a klímaváltozásból, részben a termőhelyi adottságokból adódó negatív hatásokat ellensúlyozandó a Lallemand cég egy olyan lombtrágyát (LalVigne ${ }^{\circledR}$ Mature) fejlesztett ki, amelynek használatával a fenolos érettség elősegíthető. A termék hatását Syrah szőlőfajtán vizsgáltam.

A kísérlet céljai tehát, a következőek voltak:

1. A különböző évjáratok és szüreti időpontok befolyása a Syrah szőlőfajta fenolos érettségére, három egymást követő évjáratban (2011, 2012, 2013).

2. Az újonnan kifejlesztett lombtrágya hatásának vizsgálata az érési folyamatokra Syrah szőlőfajtán, két egymást követő évjáratban (2012, 2013).

3. A Syrah „viselkedésének” vizsgálata hüvös klímaviszonyok között. A fajta honosítása csak 2008-ban történt meg, ezért hazánkban még „újnak” számít. Itthoni termesztésével kapcsolatban kevés tapasztalat áll rendelkezésre. Mediterrán származása miatt késői érésű, hosszú tenyészidejü fajta, így megfelelő beéréséhez sok napsütést és magas hőösszeget igényel. Magyarország azonban a szőlőtermesztés északi határának közelében fekszik, ezért a késői érésű fajták beérése nem minden évjáratban biztosított. 


\section{EREDMÉNYEK}

\subsection{A termésmennyiség alakulása}

A termésmennyiségek alakulását az 2. táblázat mutatja be. Ami rögtön szembetünik az a rendkívül alacsony, az Egri borvidék egészére jellemző átlagtól is jelentősen elmaradó tőketerhelés. Az értékek mindhárom évben $1 \mathrm{~kg}$ alatt maradtak. Legkevesebbet a hosszantartó aszályos időszak következményeként 2012-ben teremték a tőkék, 2013-ban a csapadékosabbra forduló idő miatt a legtöbbet. Ezek az értékek összhangban vannak a fürtátlagtömegek alakulásával. Mindhárom év esetében átlagosan $7 \mathrm{db}$ fürtöt vételeztem fel tőkénként. $\mathrm{Az}$ alacsony termésmennyiségek három tényezőre vezethetőek vissza. Egyrészt az Anyag és módszerben ismertetett különleges termőhelyi adottságokra, másrészt az alkalmazott metszésmódra, harmadrészt az extrém időjárási tényezőkre. Kijelenthető, hogy a lombtrágya az átlagos bogyótömeget és általánosságban a várható termés mennyiségét nem befolyásolta (2. táblázat). A bogyók a 2011-es évjáratban tapasztalt aszályos időjárás hatására víztartalmukat gyorsan veszítették el, az idő előrehaladtával egyre inkább betöppedtek (3. táblázat). A kontroll és a kezelt minták között csak a 2012-es évben találtam szignifikáns különbséget, akkor is csak két esetben, a 2. és a 3. mintavételi időpontban (27. ábra). A bogyók tömegére a legnagyobb befolyást az évjárat gyakorolta. A meleg, száraz időjárás hatására a szőlő erőteljesen párologtat és a bogyók gyorsan veszítik víztartalmukat, ami jelentős zsugorodásban nyilvánul meg. Ezt a jelenséget jól szemlélteti a 2012-es évjárat grafikonja (mellékletben). Az utolsó két időpont között tapasztalt növekedést az időközben lehullott csapadék okozta. Az esősebb, hűvösebb 2013-as évben a bogyók tömege csak jóval később kezdett el csökkenni és méretük, valamint tömegük is nagyobb volt minden időpontban, mint az azt megelőző évben (27. ábra).

\begin{tabular}{cccc}
\hline Évjárat & $\mathbf{2 0 1 1}$ & $\mathbf{2 0 1 2}$ & $\mathbf{2 0 1 3}$ \\
\hline Tőketerhelés (kg/töke) & 0,78 & 0,63 & 0,99 \\
Fürtszám/tőke (db/tőke) & 7 & 7 & 7 \\
Fürtátlagtömeg (g) & 127 & 88 & 131 \\
\hline
\end{tabular}

2. táblázat - A termésmennyiség alakulása a kísérlet három évében 
DOI: $10.14267 /$ phd.2015023

\begin{tabular}{cccccc}
\hline $\begin{array}{c}\text { Mintavétel } \\
\text { időpontja }\end{array}$ & 2011.08.29. & $\mathbf{2 0 1 1 . 0 9 . 0 5 .}$ & $\mathbf{2 0 1 1 . 0 9 . 1 3 .}$ & $\mathbf{2 0 1 1 . 0 9 . 2 7}$ & $\mathbf{2 0 1 1 . 1 0 . 1 0 .}$ \\
\hline $\begin{array}{c}\text { Átlagos } \\
\text { bogyótömeg }(\mathrm{g})\end{array}$ & $1,76 \pm 0,02 \alpha$ & $1,70 \pm 0,07 \beta$ & $1,57 \pm 0,01 \gamma$ & $1,38 \pm 0,02 \delta$ & $1,37 \pm 0,01 \delta$ \\
\hline
\end{tabular}

3. táblázat - Az átlagos bogyótömeg alakulása 2011-ben

A különböző görög betükkel jelölt értékek, a szüreti időpontok közötti szignifikáns különbséget jelölik. Az összehasonlításokat $p=0,05$ szinten végeztük. Minden érték az átlagot \pm a szórást jelenti.

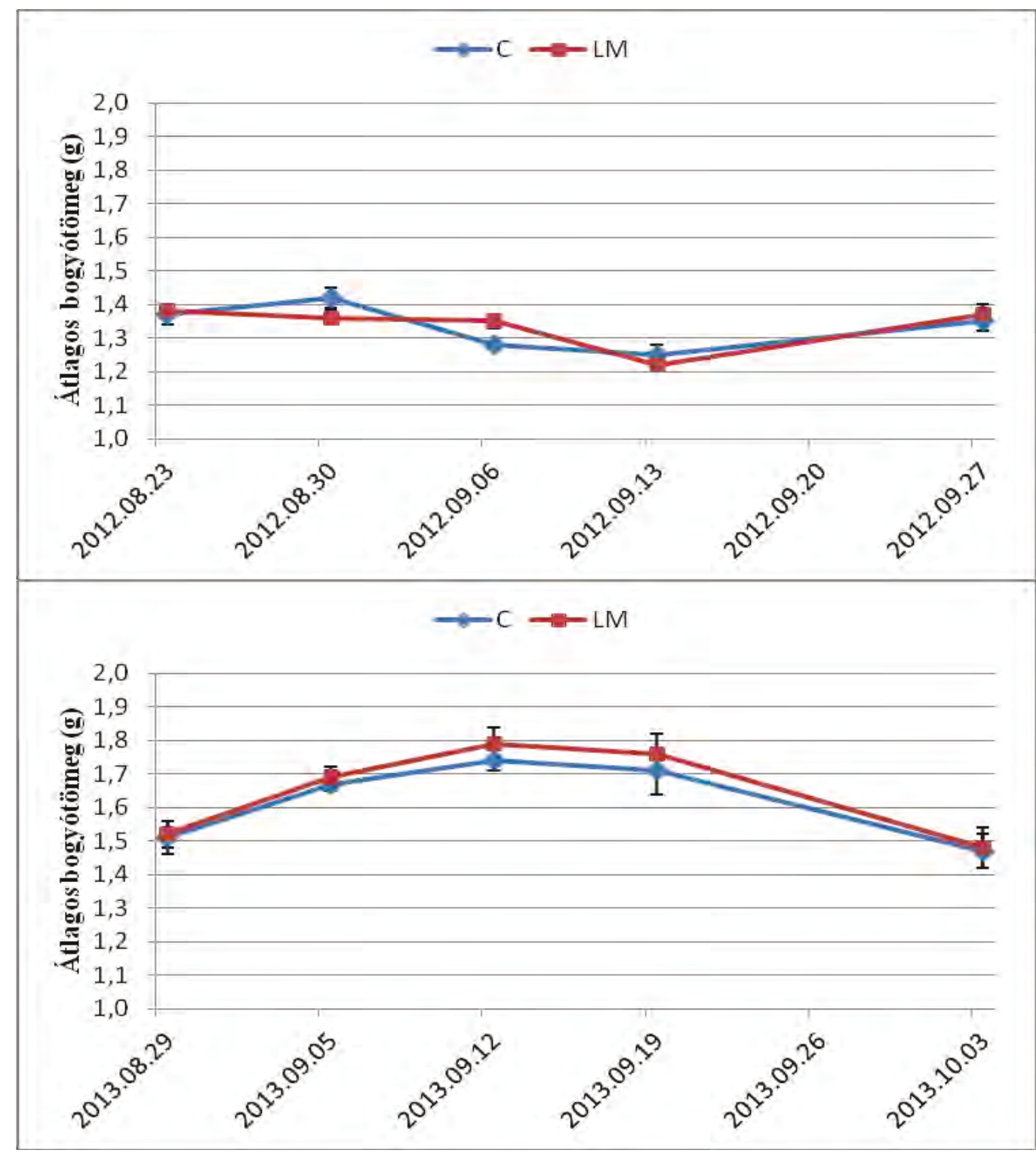

27. ábra - Az átlagos bogyótömeg alakulása 2012-ben és 2013-ban 
DOI: $10.14267 /$ phd.2015023

\subsection{A termés alapanalitikai paramétereinek változása az érés során, a 2011-es évjáratban}

A 2011-es évjáratban tapasztalt meleg, száraz időjárás, valamint a sok napsütés hatására a szőlő érése gyorsan, zavartalanul haladt (4. táblázat). A termés cukortartalma intenzíven növekedett. Az utolsó mintavételi időpontra extrém magas, 289 g/l-es értéket ért el, ami szokatlanul nagy, $17 \mathrm{v} / \mathrm{v} \%$-os várható alkoholtartalmat vetített előre. A titrálható savtartalom a hőség hatására rohamosan csökkent, ezért a szüreti időpontok megválasztásánál ügyelni kellett arra, hogy a borok nehogy túl lágyak legyenek. Az almasav szinte már a szőlőben teljesen lebomlott, így a pH ennek következményeként gyorsan nőtt.

\begin{tabular}{cccccc}
\hline Mintavétel időpontja & $\mathbf{2 0 1 1 . 0 8 . 2 9}$ & $\mathbf{2 0 1 1 . 0 9 . 0 5 .}$ & $\mathbf{2 0 1 1 . 0 9 . 1 3 .}$ & $\mathbf{2 0 1 1 . 0 9 . 2 7 .}$ & $\mathbf{2 0 1 1 . 1 0 . 1 0 .}$ \\
\hline Redukáló cukor $(\mathrm{g} / \mathrm{l})$ & $204,3 \pm 3,1 \alpha$ & $236,7 \pm 5,0 \beta$ & $255,3 \pm 3,2 \gamma$ & $272,0 \pm 1,0 \delta$ & $289,0 \pm 1,7 \varepsilon$ \\
Titrálható savtartalom $(\mathrm{g} / \mathrm{l})$ & $9,3 \pm 0,1 \alpha$ & $8,8 \pm 0,1 \beta$ & $8,1 \pm 0,1 \gamma$ & $7,3 \pm 0,1 \delta$ & $6,4 \pm 0,1 \varepsilon$ \\
$\mathrm{pH}$ & $3,14 \pm 0,02 \alpha$ & $3,21 \pm 0,01 \beta$ & $3,31 \pm 0,01 \gamma$ & $3,42 \pm 0,01 \delta$ & $3,51 \pm 0,01 \varepsilon$ \\
\hline
\end{tabular}

4. táblázat - A must rutinanalitikai értékeinek változása az érés során, 2011-ben

A különböző görög betükkel jelölt értékek, a szüreti időpontok közötti szignifikáns különbséget jelölik. Az összehasonlításokat $\mathrm{p}=0,05$ szinten végeztük. Minden érték az átlagot \pm a szórást jelenti.

\subsection{A termés alapanalitikai paramétereinek változása az érés során, a 2012-es és a 2013-as évjáratban}

\subsubsection{Cukortartalom}

A mustminták cukortartalmának változását a 28. ábra mutatja be. Rendkívül jellegzetes a markáns évjárathatás. A 2013 szeptemberében tapasztalt hideg időjárás lelassította az érési folyamatokat, így a cukorfelhalmozódás üteme lassult 2012-höz képest. Ennek megfelelően a mintavételi időpontok is egy héttel későbbre tolódtak, de még így is jelentősen alacsonyabb volt a minták cukortartalma, mint az előző évben. A kapott értékek ugyanakkor, még a gyengébb évjárat ellenére is megfelelőnek bizonyultak. A lombtrágyával kezelt és kezeletlen szőlők cukortartalma között a 2012-es évben a 2., a 3., és a 4. mintavételi időpontban találtam szignifikáns különbséget. 2013-ban az 1., a 2. és a 4. időpontban volt statisztikailag kimutatható eltérés. A 2012-es év 2. és a 2013-as év 3., valamint 5. mintavételi időpontját leszámítva, mindig a kezelt minták cukortartalma volt a magasabb. A különbségek az utolsó mintavételi időpontra mindkét évben eltüntek, ami minden bizonnyal a túlérési folyamatokkal magyarázható. 


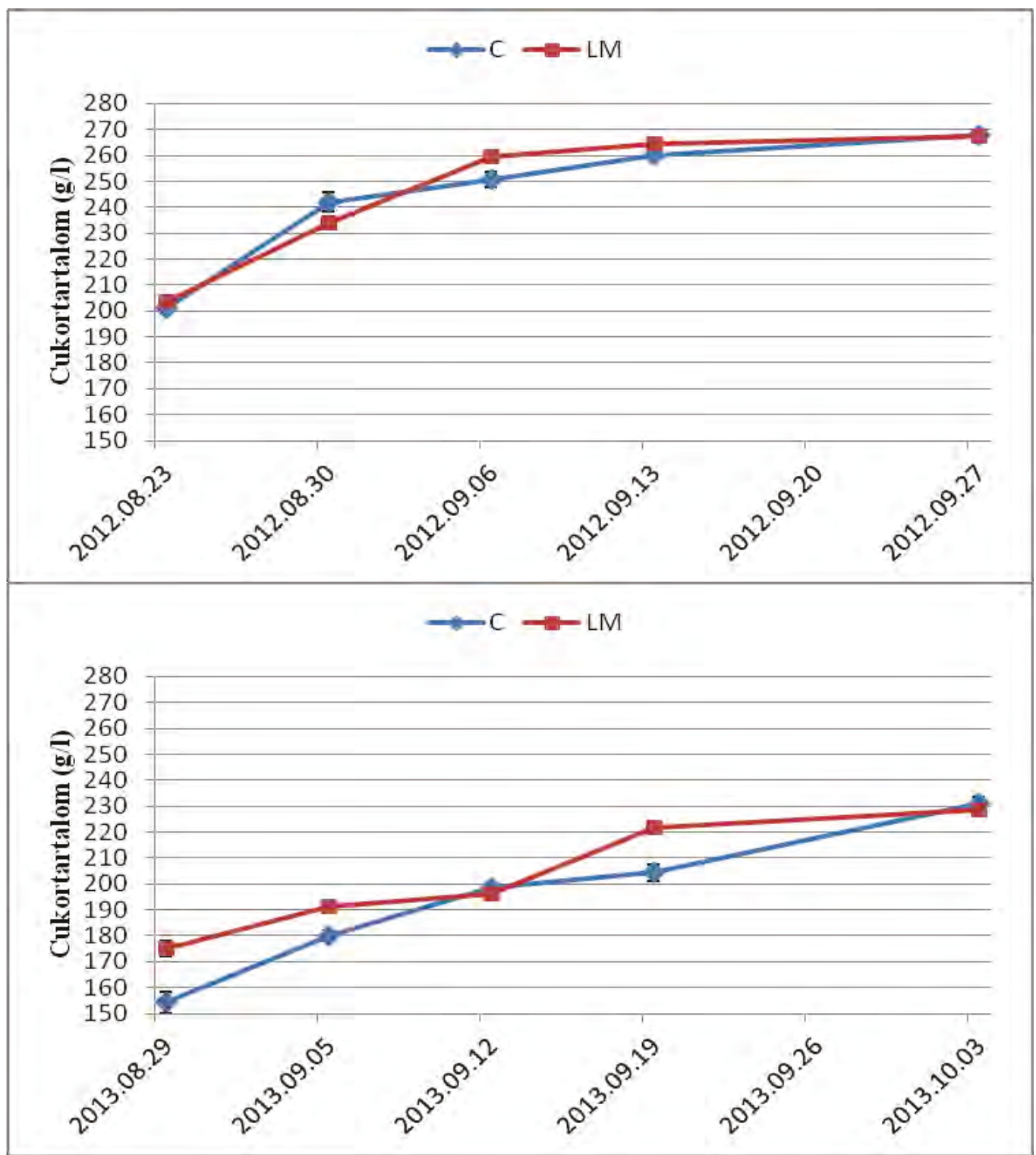

28. ábra - A kontroll (C) és kezelt (LM) mustminták cukortartalmának változása az érés során, 2012-ben és 2013-ban

\subsubsection{Titrálható savtartalom}

A kontroll és a kezelt minták között mért különbség, a kis szórásának köszönhetően minden esetben szignifikáns volt a titrálható savtartalom tekintetében (29. ábra). A 2012-es évjáratban tapasztalt magas hömérséklet hatására, a titrálható savtartalom az érés során intenzívebben csökkent. Ezt a jelenséget magas respiráció idézi elő (SWEETMAN et al. 2009). Az utolsó idöpontban viszont, a kontroll és a kezelt minták esetében is enyhe növekedés volt megfigyelhető a két héttel azelötti szüret eredményéhez képest. Az érés alatti csökkenés üteme 2013-ban a hüvösebb időjárás miatt, jóval visszafogottabb volt és jelentősen több savat tartalmazott minden minta, minden időpontban. Ebben az évben a lombtrágya hatása minden 
esetben sokkal erőteljesebben jelentkezett. Az utolsó mintavételi időpont kivételével, a kezelt mintákból préselt mustok savtartalma mindig alacsonyabb volt. A kezelt minták savtartalma az utolsó időpontra ugyanakkor enyhén emelkedett. Összességében megállapítható, hogy kizárólag a savtartalom alapján, 2012-ben a termés megfelelő érettséget ért el, hiszen a szüret időpontjára 6 g/1 alá csökkentek az értékek, szemben 2013-mal, ahol még a harmadik szüreti időpontban is 9 g/1 körül maradtak, éles savérzetű borokat eredményezve.

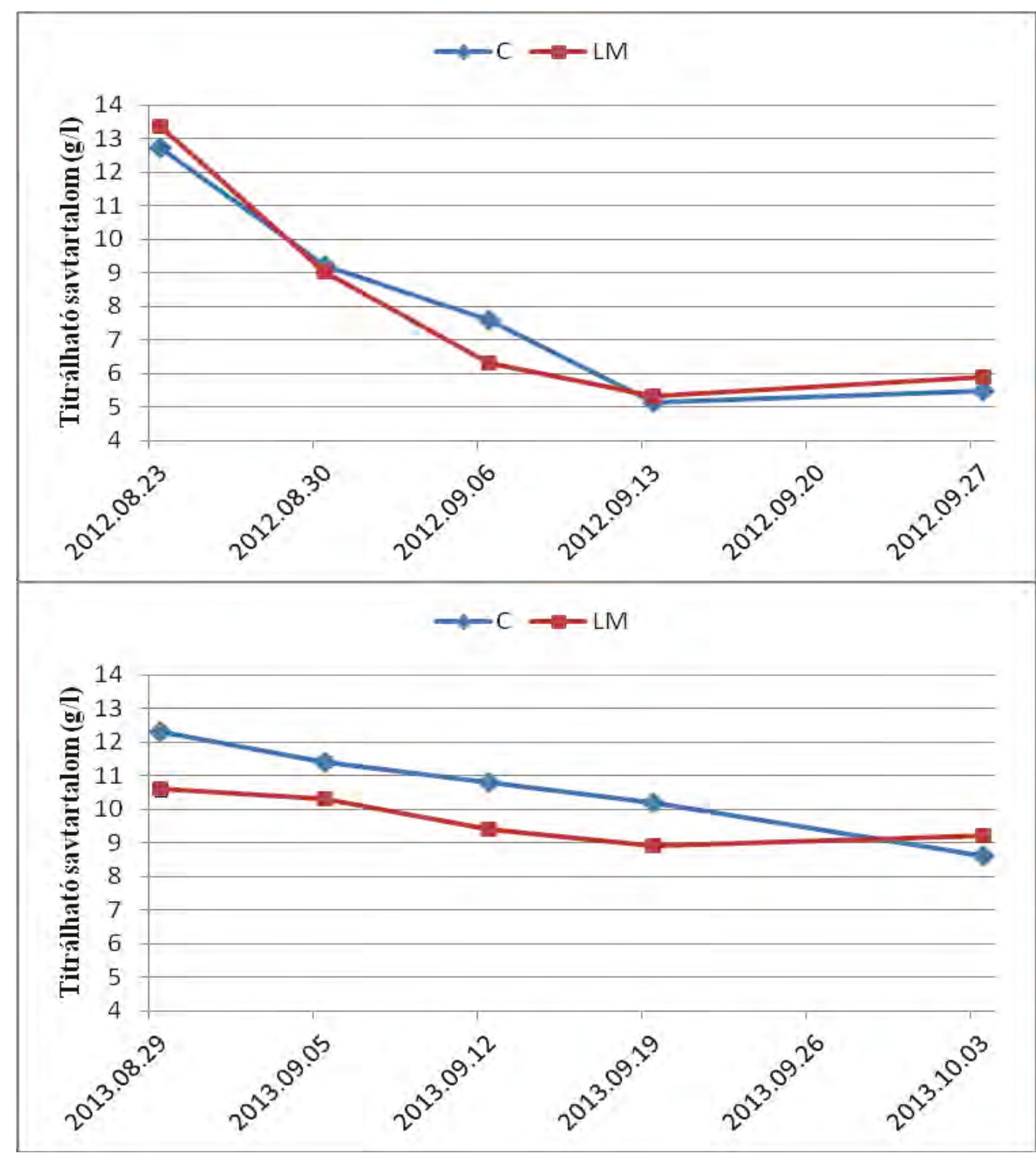

29. ábra - A kontroll $(\mathrm{C})$ és kezelt $(\mathrm{LM})$ mustminták titrálható savtartalmának változása az érés során, 2012-ben és 2013-ban 


\subsection{3. $\mathrm{pH}$}

A pH értéke, mindkét évben növekvő tendenciát mutatott az érés során (30. ábra). Az emelkedés üteme a 2012-es évben, a 2013-ashoz viszonyítva gyorsabb volt. Ez összefüggést mutat a savtartalom csökknésével, hiszen ennek a két paraméternek az alakulása ellentétes, de nem csak kizárólag a titrálható savtartalom függvénye. A kis szórás miatt, a 2013-as év 3. mintavételi időpontját leszámítva, a kezelések közötti különbség minden esetben szignifikáns volt. A lombtrágyával kezelt miták pH-ja csak a 2012-es év 1. időpontjában és a 2013-as év 3. és 5. időpontjában nem volt magasabb, mint a kontroll.

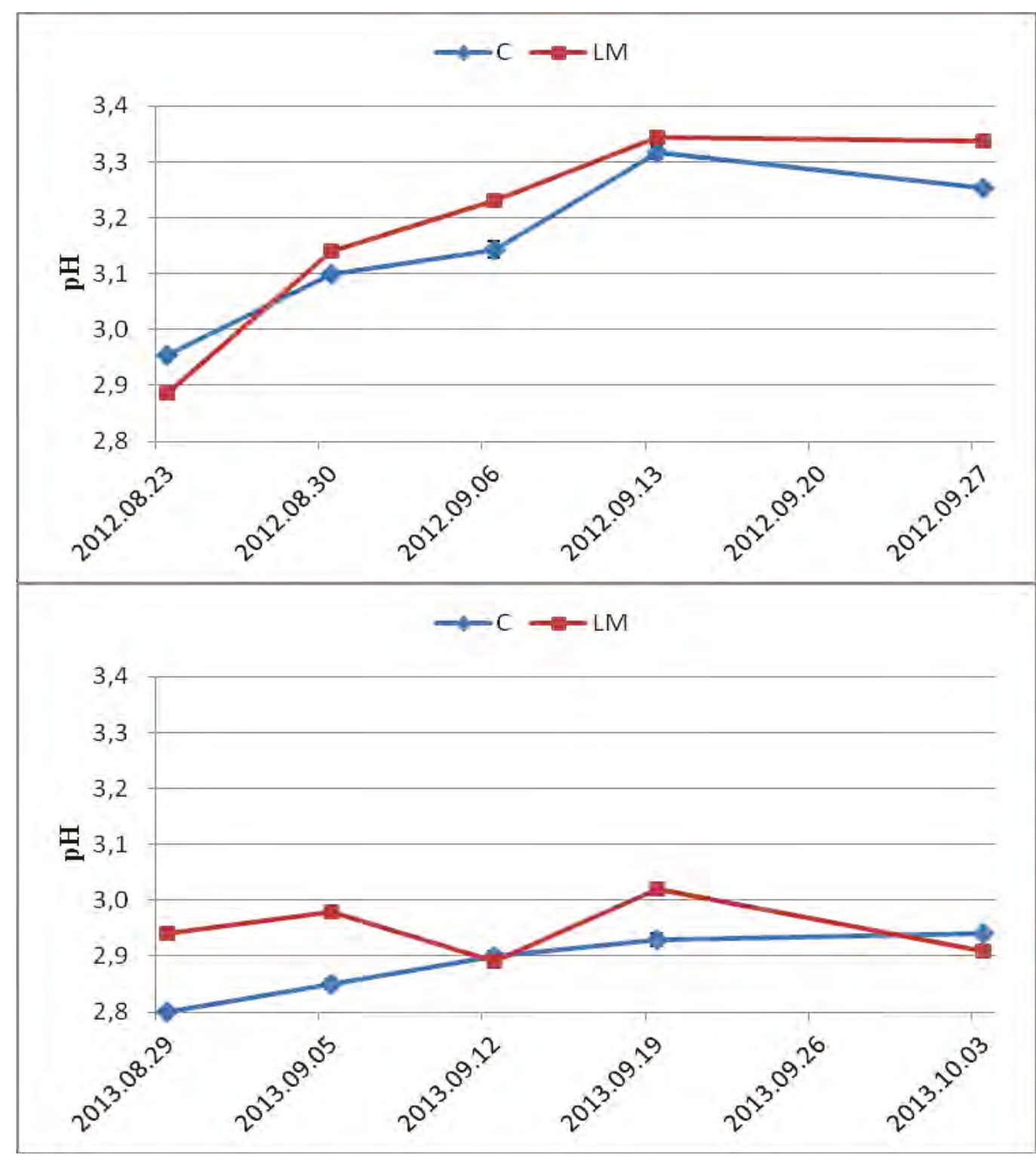

30. ábra - A kontroll (C) és kezelt (LM) mustminták pH-jának változása az érés során, 2012-ben és 2013-ban 
DOI: $10.14267 /$ phd.2015023

\subsection{A szölö fenolos érettségének változása a 2011-es évjáratban}

A fenolos érettség jellemzésére szolgáló négy fő paramétert az 5. táblázat tartalmazza. Az összes kivonható antocianin mennyisége a második szüreti idöpontra növekedett, majd a harmadikra az első szüreti időpontban mért szintre csökkent vissza. A kivonható antocianinok mennyiségében tapasztalt folyamatos csökkenés a túlérés bekövetkeztére (FERNÁNDEZ-LÓPEZ et al. 1992; FOURNAND et al. 2006) is utalhat. Ennek a tendenciának a hatására, a kivonhatósági index fokozatosan romlott, egyre nagyobb százalékot mutatott, mivel egyre több antocianin maradt vissza a bogyókban. A magérettségi index az irodalmi adatoknak megfelelően, az érés elörehaladtával csökkent (NADAL 2010), de még így sem érte el a kívánatos tartományt (<60\%) (RIBÉREAU-GAYON et al. 2006).

\begin{tabular}{cccc}
\hline Mintavétel időpontja & $\mathbf{2 0 1 1 . 0 9 . 1 3 . ~}$ & $\mathbf{2 0 1 1 . 0 9 . 2 7 .}$ & $\mathbf{2 0 1 1 . 1 0 . 1 0 .}$ \\
\hline $\begin{array}{c}\text { Összes antocianin } \\
\text { (A1) (mg/l) }\end{array}$ & $1730 \pm 100 \alpha$ & $1861 \pm 52 \alpha$ & $1732 \pm 156 \alpha$ \\
$\begin{array}{c}\text { Összes kivonható antocianin } \\
\text { (A3.4) (mg/l) }\end{array}$ & $987 \pm 54 \alpha$ & $929 \pm 60 \alpha$ & $815 \pm 28 \alpha$ \\
$\begin{array}{c}\text { Kivonhatósági index (EA\%) } \\
\text { Magérettségi index (SM\%) }\end{array}$ & $62,9 \pm 2,7 \alpha$ & $50,0 \pm 3,9 \beta$ & $52,6 \pm 5,0 \beta$ \\
\hline
\end{tabular}

5. táblázat - A szőlő fenolos érettsége a 2011-es évjáratban

A különböző görög betűkkel jelölt értékek, a szüreti időpontok közötti szignifikáns különbséget jelölik. Az összehasonlításokat $\mathrm{p}=0,05$ szinten végeztük. Minden érték az átlagot \pm a szórást jelenti.

\subsection{A szölö fenolos érettségének változása a 2012-es és a 2013-as évjáratban}

\subsection{1. Összes antocianin (A1)}

Az összes antocianin mennyisége általában 500 és 2000 mg/l között változik (RIBÉREAUGAYON et al. 2006). A képződött színanyagok mennyiségére az adott évjáratban tapasztalt időjárási viszonyok gyakorolják a legnagyobb befolyást (MORI et al. 2005; YAMANE et al. 2006; CHORTI et al. 2010). A Syrah fajta érése szempontjából minden tekintetben kedvezőbb 2012. évben jóval több színanyag képződött, mint 2013-ban (31. ábra). 2012-ben, az utolsó szüreti időpontból származó kezelt minták színanyag tartalma már csökkenni kezdett, szemben a kontroll mintákkal, amelyek továbbra is növekedést mutattak. Ez azt mutatja, hogy a lombtrágyával kezelt szőlő már két héttel hamarabb elérte antocianin termelésének csúcspontját. 2013-ban fokozatos, de lassabb ütemü növekedést tapasztaltam, a kezelés hatása ugyanakkor erőteljesebben megnyilvánult. A lombtrágya mindkét év, minden időpontjában nagyobb összes 
antocianin mennyiséget eredményezett, bár a különbségek a 2012. év esetében csak a 4. időpontban, a 2013. év esetében pedig az 1., a 3. és a 4. időpontban voltak szignifikánsak.

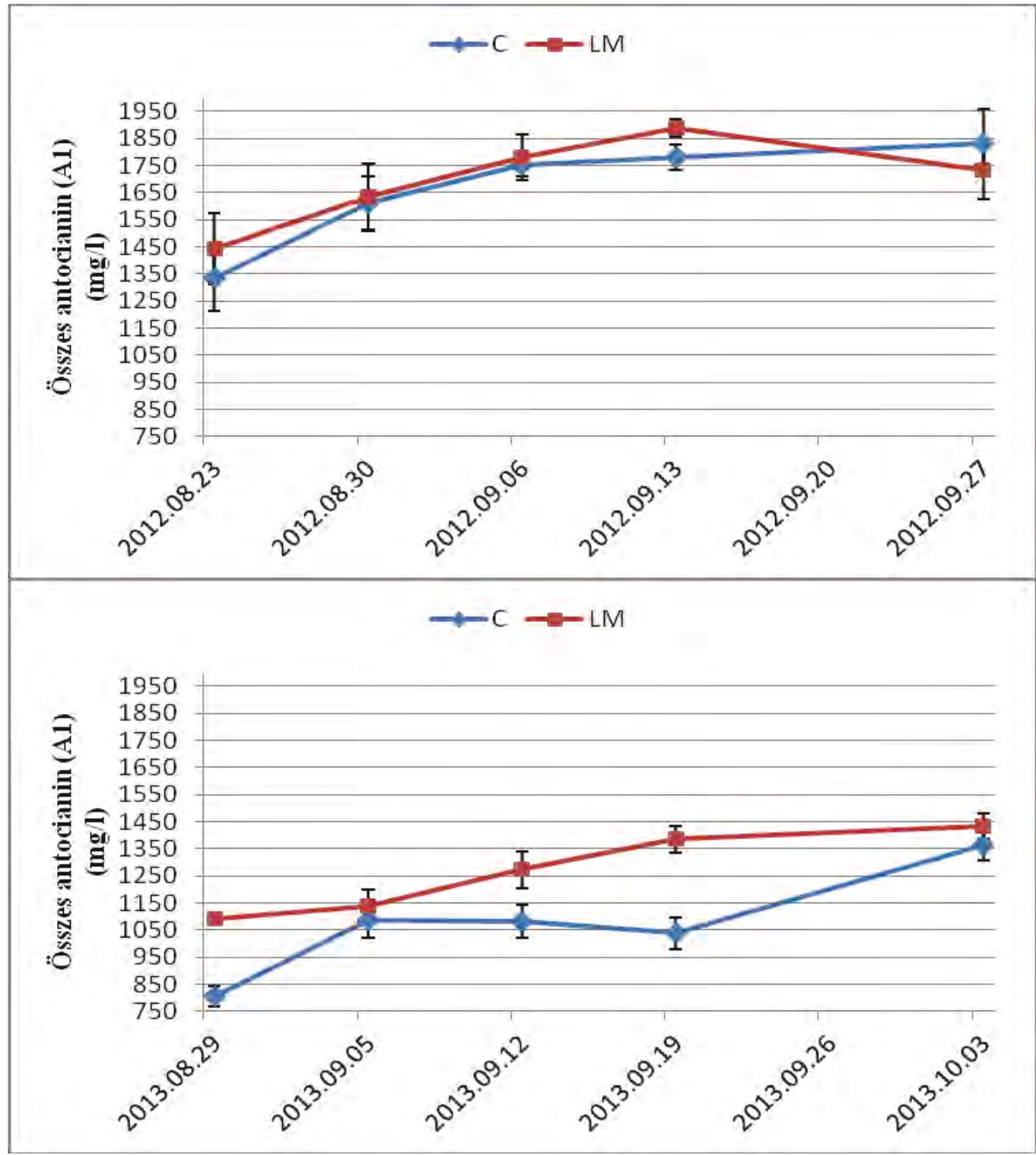

31. ábra - A kontroll (C) és kezelt (LM) bogyóminták összes antocianintartalmának (A1) változása az érés során, 2012-ben és 2013-ban

\subsection{2. Összes kivonható antocianin (A3.4)}

Az alkalmazott lombtrágya, a kivonható antocianinok mennyiségét mindkét évjáratban egyértelmüen megnövelte (32. ábra). Hasonlóan az összes antocianin mennyiségének alakulásához, a 2012-es év eredményezte a magasabb értékeket. Erre az évre, a csúcspont eléréséig a fokozatos növekedés, majd az ezt követő csökkenés a jellemző, szemben a következő évvel, ahol az értékek folyamatosan, de lassan emelkedtek az érés során, ám a csúcspont eléréséhez még több időre lett volna szükség. A 2012-es év 4., valamint 5. időpontját leszámítva, 
mindenhol statisztikailag kimutatható különbség volt a kontroll és a kezelt minták között az összes kivonható antocianinra vonatkozóan.

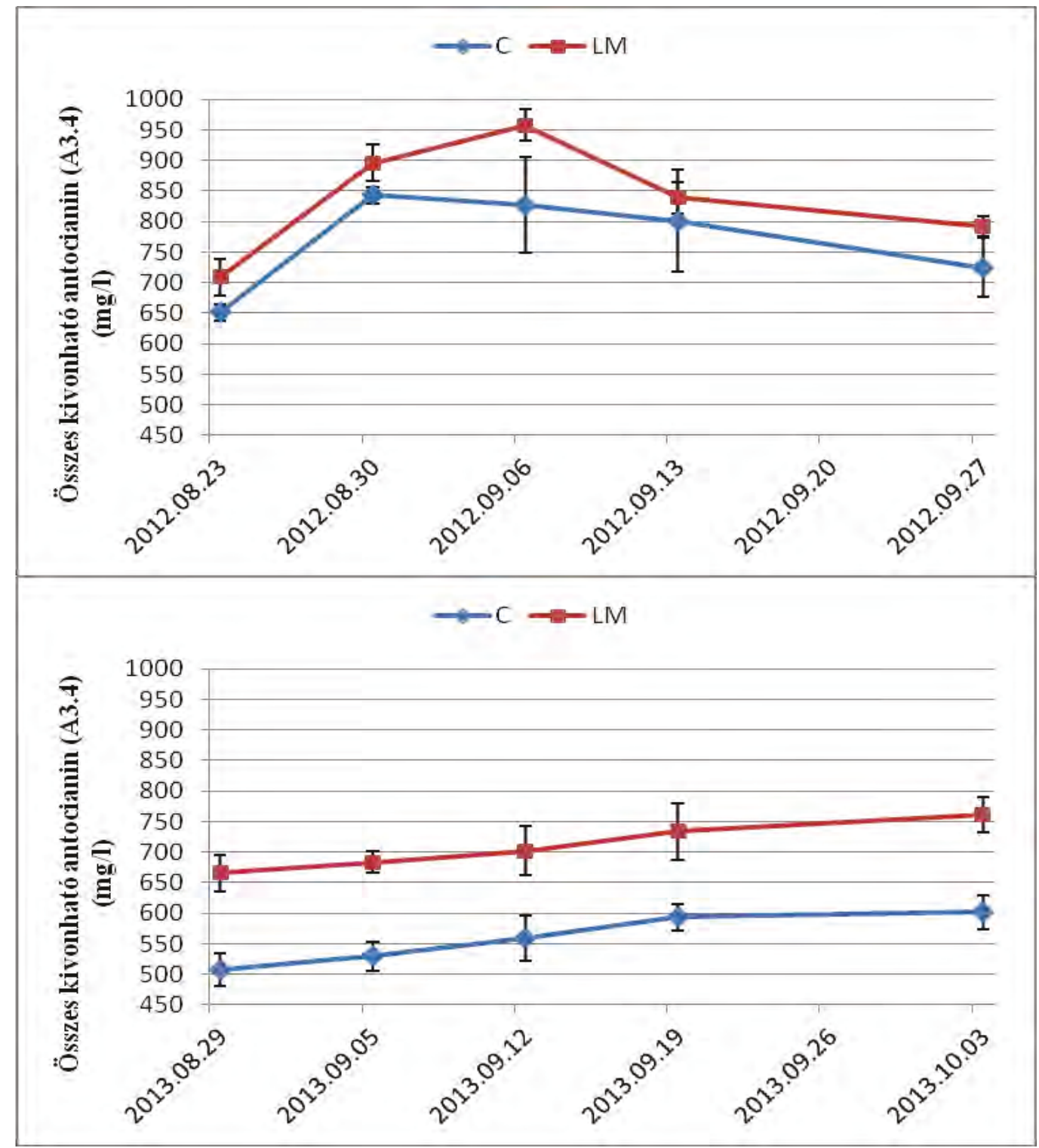

32. ábra - A kontroll (C) és kezelt (LM) bogyóminták összes kivonható antocianintartalmának $(A 3,4)$ változása az érés során, 2012-ben és 2013-ban 


\subsubsection{Kivonhatósági index (EA\%)}

A 33. ábra alapján megállapítható, hogy az indexek meglehetősen rendszertelenül változnak az érés során: esetenként jelentős mértékü csökkenést, majd növekedést tapasztaltam. Ez a jelenség főként, a bogyóhéj sejtfalának érés alatt történő összetételbeli változásaira vezethető vissza. A poliszacharidok (galaktóz, arabinóz stb.) és a cellulóz mennyisége, valamint a pektinek metilezettségi foka, illetve az ezekhez való kötődés a felelős az antocianinok eltérő mértékü kioldhatóságáért (ORTEGA-REGULES et al. 2006; ORTEGA-REGULES et al. 2008; HANLIN et al. 2010; HERNÁNDEZ-HIERRo et al. 2014). Emellett a bogyóhéj vastagsága szintén fontos tényező (ORTEGA-REgules et al. 2006; Río SEGADE et al. 2011a). Ezekből a megállapításokból azt a következtetést vonhatjuk le, hogy a magasabb összes antocianin tartalommal (A1) rendelkező szőlőből, nem minden esetben készíthető magasabb antocianin tartalmú bor. Az antocianinkoncentráció nyomon követése önmagában tehát nem elegendő, az érés során. Érdemes lenne tehát, a jövőbeni érésdinamikai kutatások során a sejtfal felépítését is vizsgálni, ami nemcsak a kivonhatóságra, de a bogyó fizikai paramétereire is hatással van (ORTEGARegules et al. 2006; ORTEGA-Regules et al. 2008). A 33. ábrán bemutatott eredmények és időbeni változásuk összhangban vannak más kutatók megállapításaival (FoURNAND et al. 2006; PÉREZ-MAgAriÑo ÉS GonZÁlez-SAn José 2006; HERnÁNDEZ-Hierro et al. 2012), miszerint a kivonhatóság mérték a rendszertelenül változik és mindig csak az adott mintavételi időpontra értelmezhető, valamint hogy nem esik egybe a technológiai érettséggel (GONZÁLEZ-NEVES et al. 2004a; GonZÁleZ-NeVES et al. 2004b; ROMERO-CASCALES et al. 2005; GONZÁLEZ-NEVES et al. 2010b; CAGNASSO et al. 2011). A kezelt minták kivonhatósági indexe a 2012. év 4. mintavételi időpontját, és a 2013. év 1. és 4. mintavételi időpontját leszámítva mindenhol kedvezőbben alakult, bár szignifikáns különbségeket csak három esetben találtam, a 2012-es évjárat 3. és a 2013-as évjárat 2. és 5. időpontjában. NADAL (2010) szerint a kivonhatósági értékek optimális tartománya 0 és 30 között Ezt az értéket ugyan egyetlen esetben sem sikerült elérni, de ettől eltekintve a szőlőminták és a borok is megfelelö mennyiségü színanyagot tartalmaztak, kiváltképp a 2012-es évjáratban. 


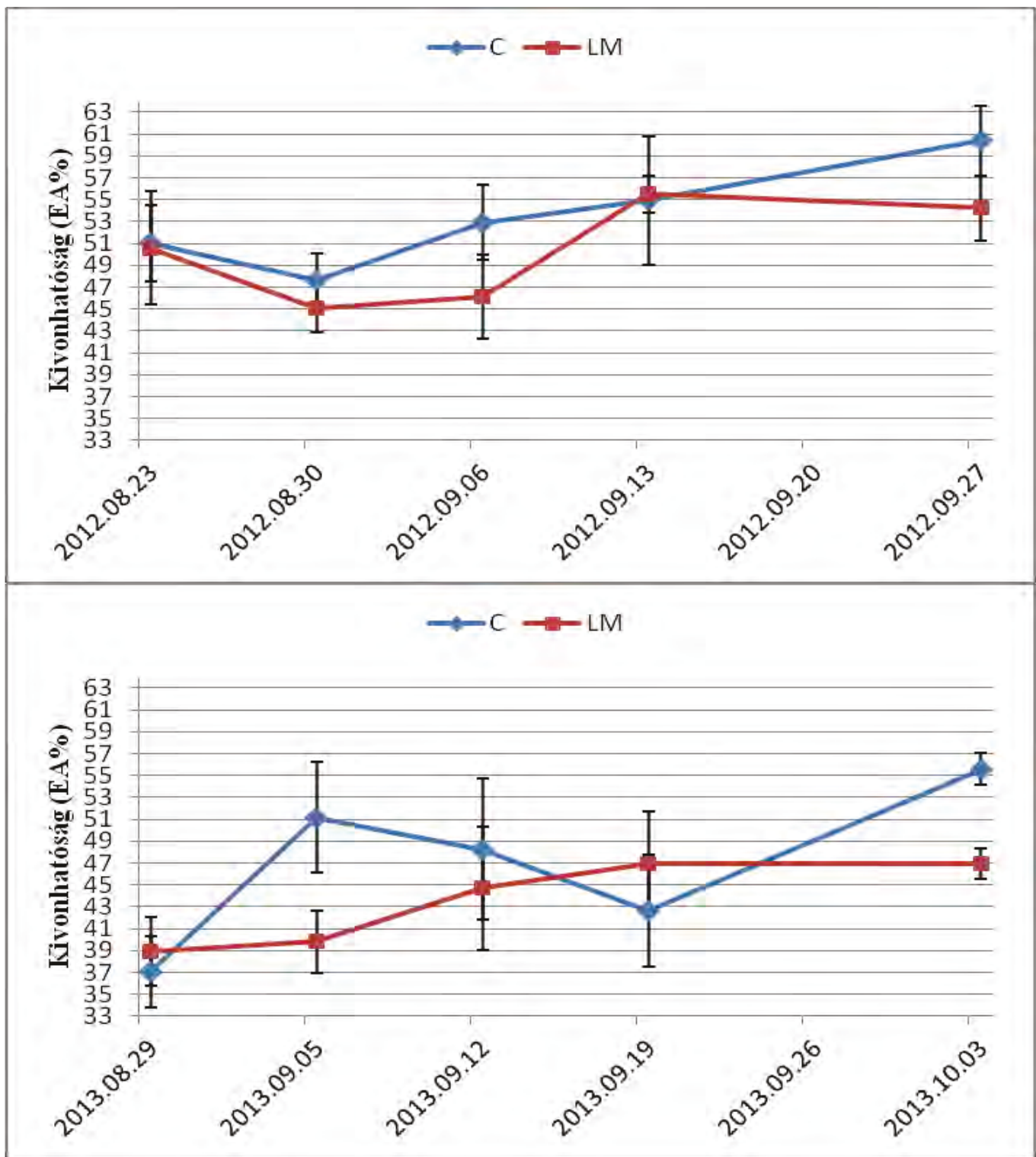

33. ábra - A kontroll (C) és kezelt (LM) bogyóminták kivonhatósági indexének (EA\%) változása az érés során, 2012-ben és 2013-ban

\subsubsection{Magérettségi index (SM\%)}

A kísérlet eredményei szerint a magérettségi adatok ebben a formában csak feltételesen alkalmazhatóak tudományos következtetések levonására (34. ábra). Az értékek nagyon rendszertelenül változnak és jellemző az ismétlések közötti nagy szórás. Irodalmi adatok szerint a $60 \%$ feletti értékek azt mutatják, hogy a mag még nem érett be kellően és sok olyan kevéssé polimerizált tannint tartalmaz, amely húzós, éretlen, zöld ízjegyekkel rendelkező bort eredményez (RIBÉREAU-GAYON et al. 2006; NADAL 2010). A lombtrágya használata a magérettséget nem befolyásolta. Megjegyzendő, hogy a magvak, akárcsak a héj, az érés során számos hisztokémiai átalakuláson mennek át, amely a fenolok különböző mértékü kioldódásában nyilvánul meg (CADOT et al. 2006; MATTIVI et al. 2009). 
DOI: $10.14267 /$ phd.2015023

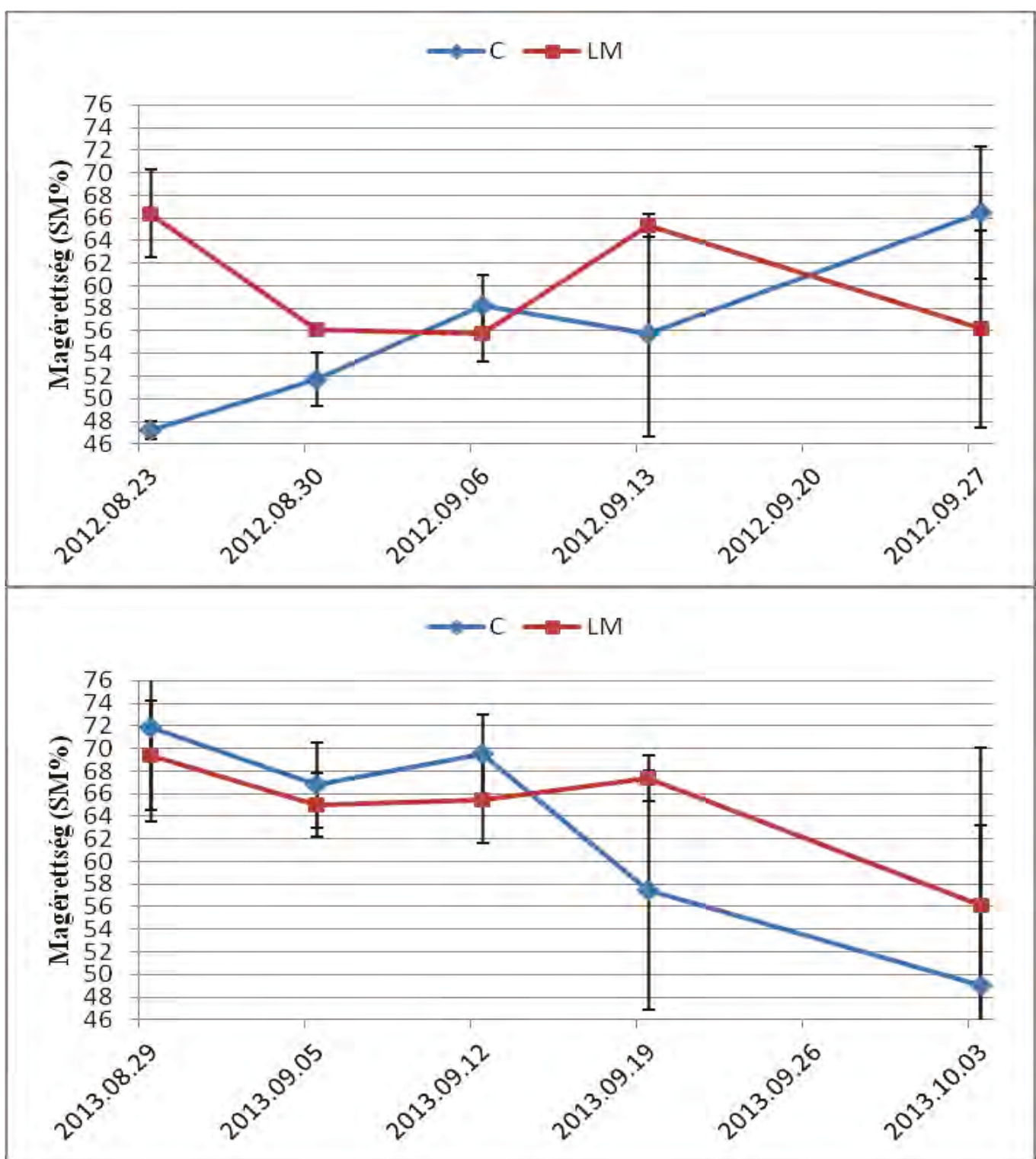

34. ábra - A kontroll (C) és kezelt (LM) bogyóminták magérettségi indexének (SM\%) változása az érés során, 2012-ben és 2013-ban

\subsection{A szölö fizikai paramétereinek változása a 2011-es évjáratban}

A héj keménysége $\left(\mathrm{F}_{\mathrm{sk}}\right)$, Young modulusa $\left(\mathrm{E}_{\mathrm{sk}}\right)$, az átszakításhoz szükséges erő $\left(\mathrm{W}_{\mathrm{sk}}\right)$ mind csökkenő tendenciát mutatott az érés során. A bogyó egyre puhábbá vált $(\mathrm{BH})$, ezzel együtt a többi kiegészítő paraméter (BCo, BS, BCh, BR) értéke is csökkent. A héj vastagsága a második szüreti időpontra emelkedett, majd a harmadikra csökkent, bár a szüreti időpontok közötti különbség nem volt szignifikáns. A mag fizikai tulajdonságai nem változtak jelentős mértékben (6. táblázat). 


\begin{tabular}{cccc}
\hline $\begin{array}{c}\text { Mintavétel } \\
\text { időpontja }\end{array}$ & $\mathbf{2 0 1 1 . 0 9 . 1 3 .}$ & $\mathbf{2 0 1 1 . 0 9 . 2 7 .}$ & $\mathbf{2 0 1 1 . 1 0 . 1 0 .}$ \\
\hline $\mathrm{F}_{\mathrm{sk}}(\mathrm{N})$ & $0,438 \pm 0,071 \alpha$ & $0,435 \pm 0,100 \alpha \beta$ & $0,393 \pm 0,089 \beta$ \\
$\mathrm{E}_{\mathrm{sk}}(\mathrm{N} / \mathrm{mm})$ & $0,450 \pm 0,063 \alpha$ & $0,449 \pm 0,078 \alpha$ & $0,391 \pm 0,114 \beta$ \\
$\mathrm{W}_{\mathrm{sk}}(\mathrm{mJ})$ & $0,258 \pm 0,068 \alpha$ & $0,257 \pm 0,094 \alpha$ & $0,245 \pm 0,083 \alpha$ \\
\hline $\mathrm{BH}(\mathrm{N})$ & $3,81 \pm 0,62 \alpha$ & $3,54 \pm 0,69 \alpha \beta$ & $3,26 \pm 0,93 \beta$ \\
$\mathrm{BCo}(-)$ & $0,64 \pm 0,06 \alpha$ & $0,61 \pm 0,06 \beta$ & $0,60 \pm 0,07 \beta$ \\
$\mathrm{BG}(\mathrm{N})$ & $2,41 \pm 0,36 \alpha$ & $2,15 \pm 0,43 \beta$ & $1,94 \pm 0,52 \beta$ \\
$\mathrm{BS}(\mathrm{mm})$ & $2,94 \pm 0,19 \alpha$ & $2,54 \pm 0,20 \beta$ & $2,42 \pm 0,40 \beta$ \\
$\mathrm{BCh}(\mathrm{mJ})$ & $7,11 \pm 1,30 \alpha$ & $5,50 \pm 1,36 \beta$ & $4,86 \pm 1,86 \beta$ \\
$\mathrm{BR}(-)$ & $0,30 \pm 0,04 \alpha$ & $0,28 \pm 0,04 \beta$ & $0,26 \pm 0,04 \beta$ \\
\hline $\mathrm{Sp}_{\mathrm{sk}}(\mathrm{mm})$ & $0,184 \pm 0,032 \alpha$ & $0,206 \pm 0,044 \beta$ & $0,178 \pm 0,034 \alpha$ \\
\hline $\mathrm{F}_{\mathrm{s}}(\mathrm{N})$ & $34,53 \pm 8,19 \alpha$ & $32,80 \pm 6,46 \alpha \beta$ & $30,78 \pm 6,10 \beta$ \\
$\mathrm{E}_{\mathrm{s}}(\mathrm{N} / \mathrm{mm})$ & $73,08 \pm 11,31 \alpha$ & $78,92 \pm 13,77 \alpha$ & $75,27 \pm 12,87 \alpha$ \\
$\mathrm{W}_{\mathrm{s}}(\mathrm{mJ})$ & $7,71 \pm 2,79 \alpha$ & $6,74 \pm 2,01 \alpha \beta$ & $6,05 \pm 1,76 \beta$ \\
\hline
\end{tabular}

6. táblázat - A szőlő fizikai paramétereinek változása az érés során a 2011-es évjáratban

A különböző görög betükkel jelölt értékek, a szüreti időpontok közötti szignifikáns különbséget jelölik. Az összehasonlításokat $p=0,05$ szinten végeztük. Minden érték az átlagot \pm a szórást jelenti.

\subsection{A szölö fizikai paramétereinek változása a 2012-es és 2013-as évjáratban}

\section{A bogyóhéj keménysége $\left(\mathrm{F}_{\mathrm{sk}}\right)$, Young modulusa $\left(\mathrm{E}_{\mathrm{sk}}\right)$ és a héj átszakításához szükséges munka $\left(\mathbf{W}_{\mathrm{sk}}\right)$}

Az értékek mindkét évben hasonló tartományban változtak. A lombtrágya hatására a bogyók héjának keménysége csökkent. Az értékek 2012-ben az utolsó két mintázási időpontban ugyan nagyobbak voltak a kezelt minták esetében, de a különbség nem volt szignifikáns. Ebben az évben csak a 3. időpontból származó minták között volt statisztikailag kimutatható különbség a kontroll és kezelt bogyók között, míg 2013-ban a 3. időpontot leszámítva mindenhol. Összességében a csökkenő tendencia jellemezte ezeket az értékeket az érés során. Külföldi publikációk arról számoltak be, hogy a bogyó héjkeménysége és az antocianinok kivonhatósága között összefüggés áll fenn (Río SEGADE et al. 2008a; Rolle et al. 2008, 2009; TORCHIO et al. 2010; Río SEGADE et al. 2011c). A keményebb bogyóhéjhoz nagyobb kivonhatóság társult, amit a héj sejtfalának nagyobb törékenységével magyaráznak (ROLLE et al. 2008; RoLlE et al. 2011c). Kutatásaim során nem sikerült ilyen összefüggést kimutatni a két paraméter között. Ráadásul a puhább bogyóhéjhoz (35. ábra) sok esetben nagyobb kivonhatóság (33. ábra) is társult a lombtrágyával kezelt szőlő esetében. A Young modulus $\left(\mathrm{E}_{\mathrm{sk}}\right)$ értéke (36. ábra) a héj keménységével szinkronban változott. A puhuló héj egyre kevésbé tudott a deformációnak ellenállni. A lombtrágyának erre a paraméterre csak a 2013-as évjárat utolsó időpontjában volt 
hatása. A bogyóhéj átszakításához szükséges munka ( $\left.\mathrm{W}_{\mathrm{sk}}\right)$, a 2012-es évben alig változott az érés során és a kontroll, valamint a kezelt minták sem különültek el egymástól. Ennél a paraméternél csak 2013-ban, a második és az utolsó két szüreti időpontból származó minták között volt szignifikáns különbség. A lombtrágyával kezelt, a kontrollhoz viszonyítva puhább héj átszúrása kisebb munkával is megtörtént (37. ábra).

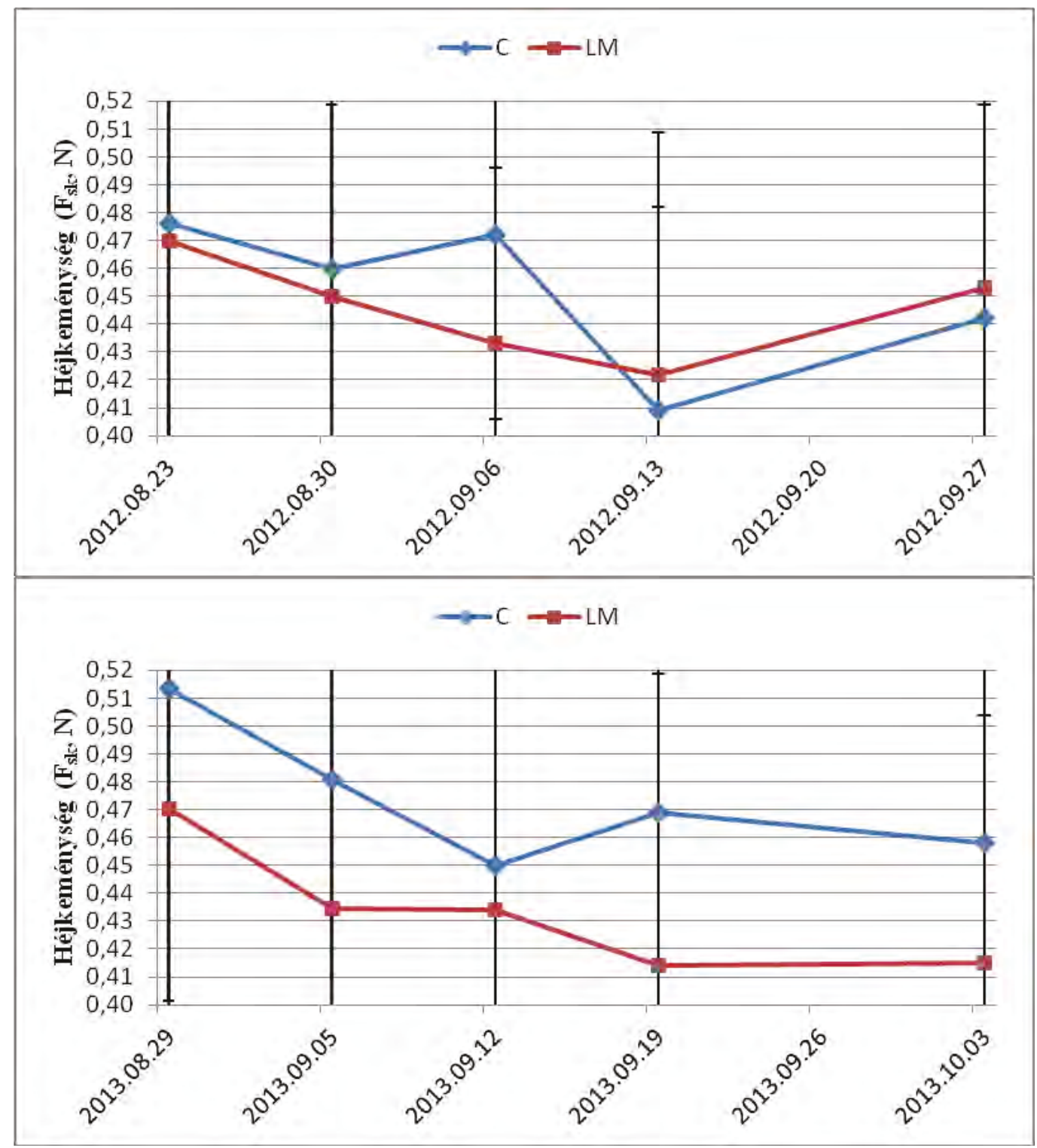

35. ábra - A héjkeménység $\left(F_{\mathrm{sk}}\right)$ alakulása 2012-ben és 2013-ban 
DOI: $10.14267 /$ phd.2015023

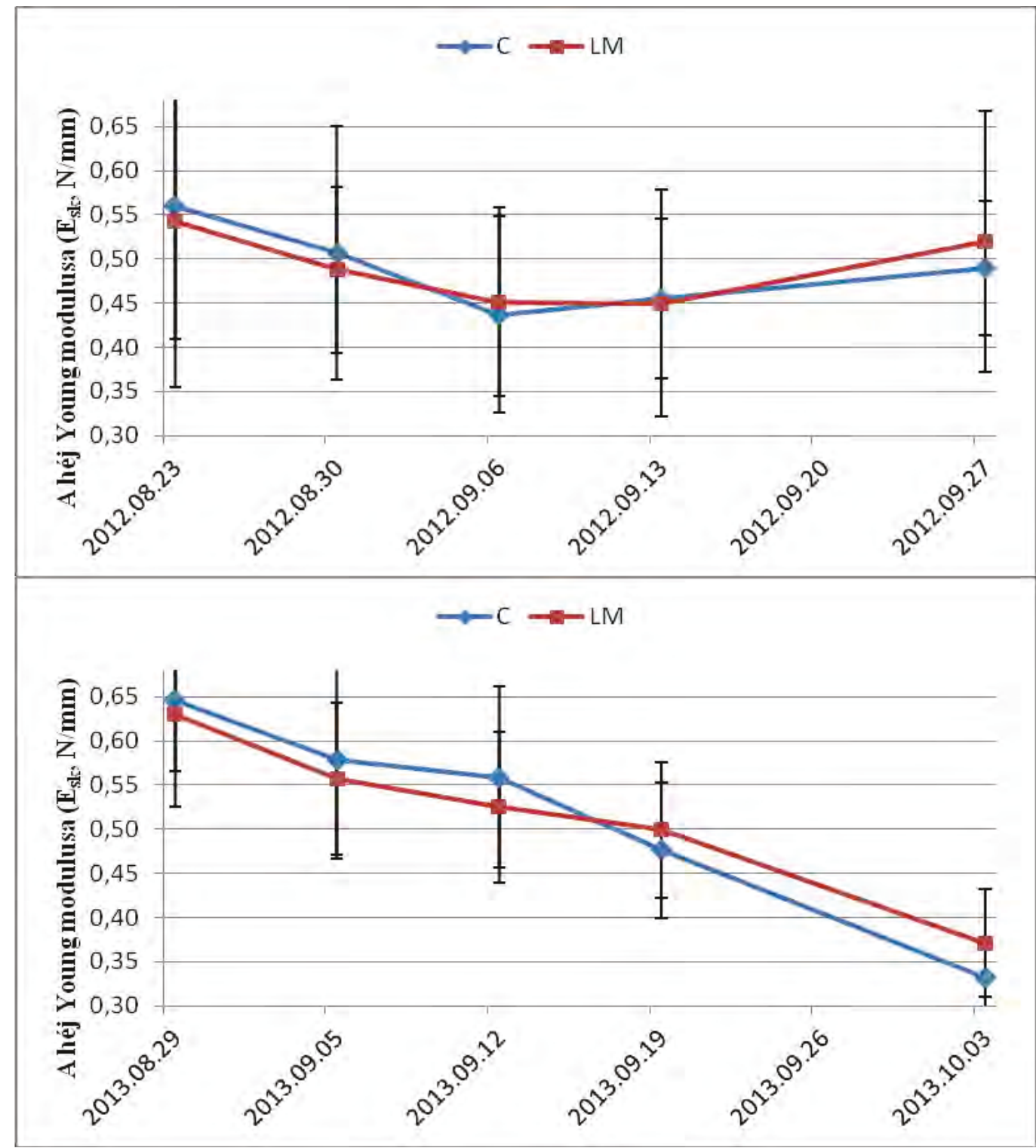

36. ábra - A héj Young modulusának $\left(E_{\mathrm{sk}}\right)$ alakulása 2012-ben és 2013-ban 
DOI: $10.14267 /$ phd.2015023

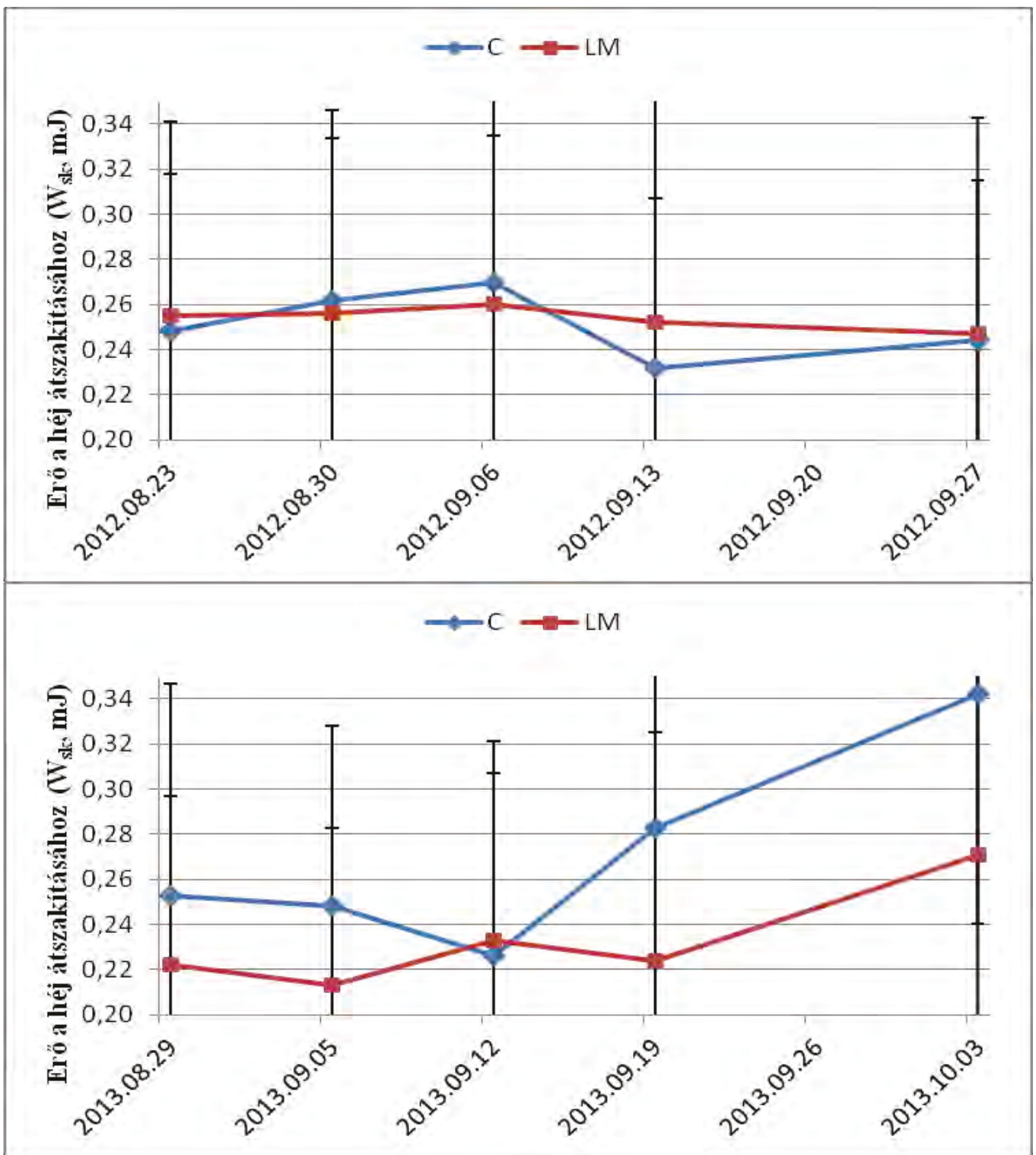

37. ábra - A héj átszakításához szükséges erő $\left(\mathrm{W}_{\mathrm{sk}}\right)$ alakulása 2012-ben és 2013-ban 


\section{A bogyó keménysége (BH)}

A bogyók az érés során mindkét évjáratban egyre puhábbakká váltak (38. ábra). A 2012es év utolsó mintavételi időpontjára tapasztalt növekedést, az utolsó két szüret között lehullott eső okozta. A bogyók megszívták magukat vízzel, teltebbé, keményebbé váltak. A lombtrágya 2012-ben minden időpontban keményebb bogyókat eredményezett. A különbség három esetben az 1., a 3. és az 5. mintázásnál volt szignifikáns. 2013-ban a különbségek jóval kisebbek voltak a kezelések között. Jelentős eltérés a kontroll és a kezelt bogyók között csak az 1. és a 4. időpontban volt megfigyelhetö.

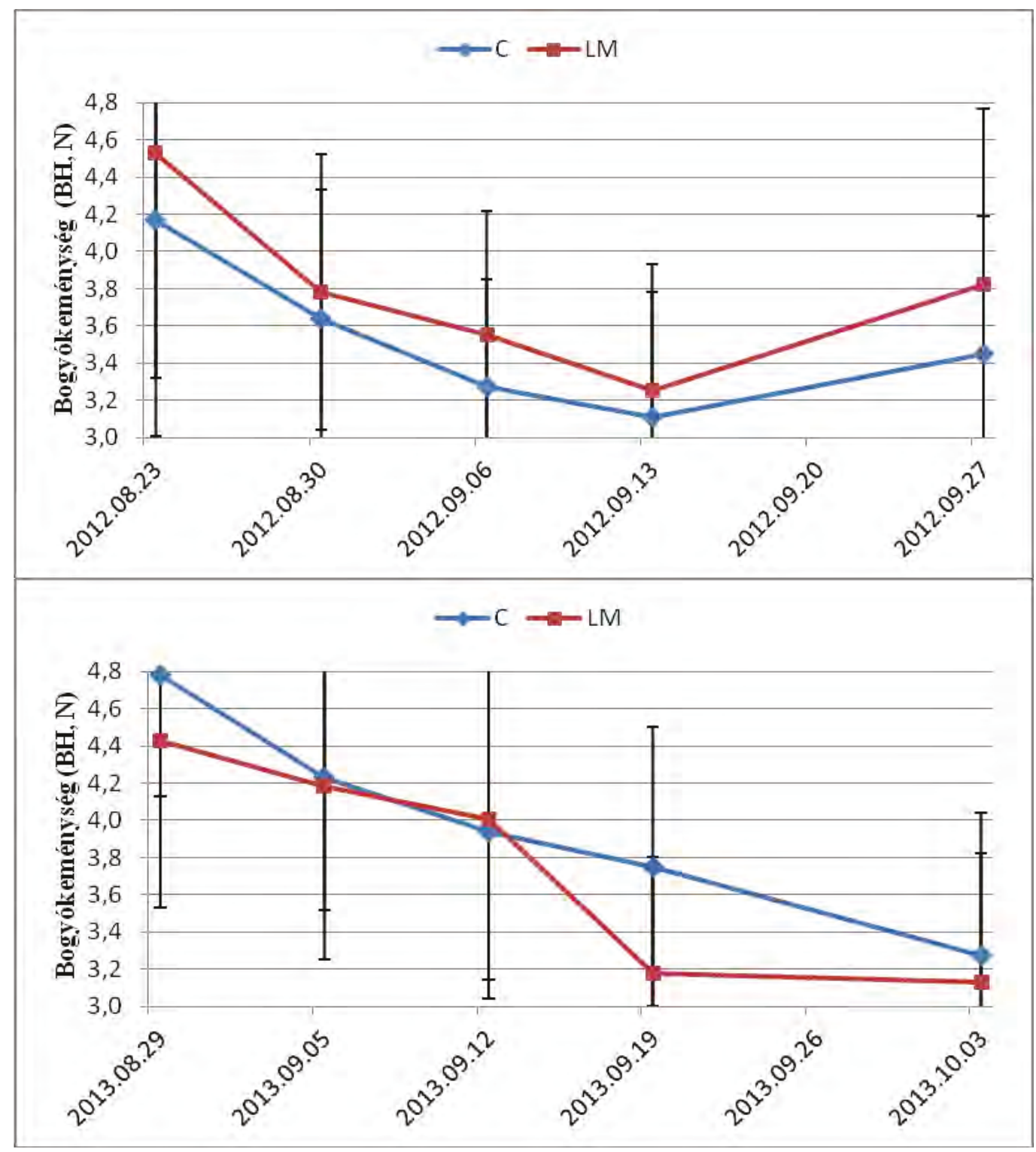

38. ábra - A bogyókeménység (BH) alakulása 2012-ben és 2013-ban 
DOI: $10.14267 /$ phd.2015023

\section{A bogyókeménységből származtatott egyéb adatok, valamint a mag fizikai paraméterei}

Az adathalmaz nagysága miatt és a könnyebb áttekinthetőség érdekében, az eredményeket táblázatos formában, két részre bontva mellékletként közlöm. A mag fizikai paramétereire a lombtrágyás kezelés nem, ellenben az évjárat igen jelentős mértékben gyakorolt hatást. A kapott adatokból megállapítható, hogy a magvak, a zsendülés időszakára már elérik végleges keménységüket, fizikai tulajdonságaik a szüretig már csak kis mértékben változnak. Ezért célravezetőbb lenne ezeket a vizsgálatokat, a bogyókötődés és a zsendülés közötti időszakban elvégezni. A bogyókeménységből számítható egyéb textúra adatokat (bogyókeménység ( $\mathrm{BH}, \mathrm{N})$, bogyókohézió ( $\mathrm{BCo},-)$, bogyónyúlósság ( $\mathrm{BG}, \mathrm{N})$, bogyóruganyosság $(\mathrm{BS}, \mathrm{mm})$, bogyórághatóság $(\mathrm{BCh}, \mathrm{mJ})$, bogyórugalmasság $(\mathrm{BR},-))$ elsősorban csemegeszőlők jellemzésére használják (ROLLE et al. 2011a; Río SEGADE et al. 2013). Az értékek között az alkalmazott kezelés, az évjárat és a mintavételi időpont is csak néhány estben okozott szignifikáns különbséget. 


\section{A bogyóhéj vastagsága $\left(\mathrm{Sp}_{\mathrm{sk}}\right)$}

A lombtrágya használata minden időpontban szignifikánsan vastagabb bogyóhéjat eredményezett (39. ábra). A nagy mintaszám miatt $(\mathrm{n}=50)$, a magas szórás ellenére, minden időpontban sikerült statisztikailag kimutatható eltérést bizonyítani. A vastagabb bogyóhéj lehet az egyik válasz arra, hogy a fenolos érettségi vizsgálatok során miért volt magasabb a kezelt bogyók antocianin tartalma. ORTEGA-Regules et al. (2006) és Río SEGADE et al. (2011a) kutatásaiban, a vastagabb héjhoz rosszabb kivonhatósági értékek tartoztak, jóllehet az egri vizsgálatok ezt nem minden esetben erősítették meg (33. ábra).

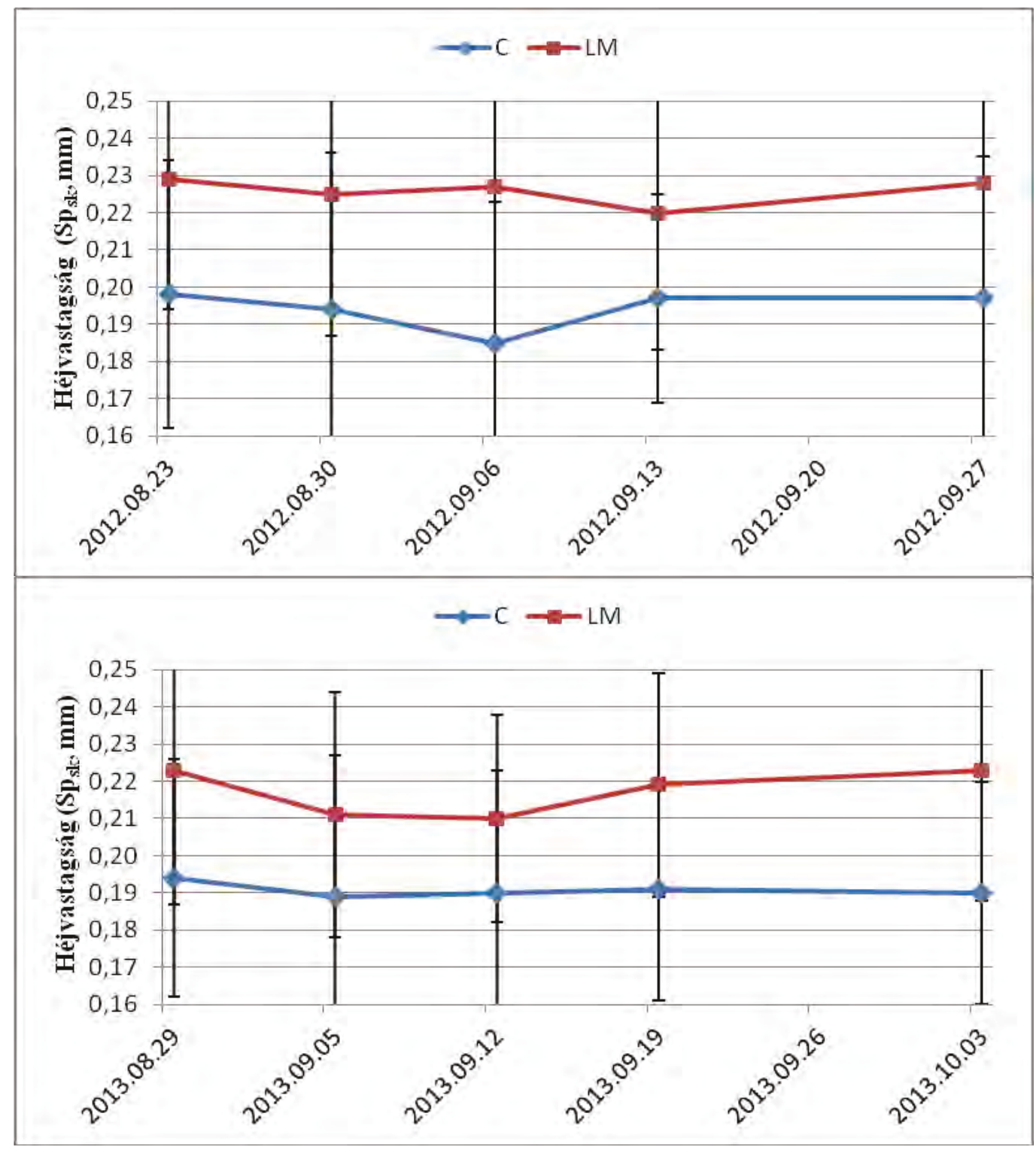

39. ábra - A héjvastagság $\left(\mathrm{Sp}_{\mathrm{sk}}\right)$ alakulása 2012-ben és 2013-ban 


\subsection{A 2011-es borok analitikai paraméterei}

A 2011-es évjárat a kísérlet céljára kijelölendő terület homogenitásának vizsgálatára szolgáló év volt, így lombtrágya alkalmazására még nem került sor. A kísérleti borokat a különböző szüreti időpontok alapján hasonlítottuk össze (7. táblázat). A borok alkoholtartalma igen magas volt, köszönhetően a kiváló évjáratnak, mely során sok cukor termelődött. Az utolsó szüreti időpont borának 16,50 v/v\%-os értéke már igen kiemelkedőnek számít. Az extrakttartalom szintén magasnak bizonyult és az érés során növekvő tendenciát mutatott. A titrálható savtartalom ezzel szemben folyamatosan csökkent. A szüret időpontjainak kiválasztásánál ügyelni kellett arra, hogy a borok nehogy túlságosan lelágyuljanak. Az alacsony savtartalom következtében a borok pH értékei igen magasnak bizonyultak (3,45-3,77). Az összes polifenol mennyisége folyamatosan növekvő tendenciát mutatott az érés során csakúgy, mint a leukoantocianinok koncentrációja. A katechinek kezdeti magas koncentrációja a második bornál csaknem a felére csökkent, majd a harmadik időpontban, csaknem az első bornál tapasztalt szintre tért vissza. Az antocianinok mennyisége az első és a második szüreti időpont között nőtt, majd a harmadikra kissé csökkent. A borok mindegyike igen magas színintenzitással jellemezhető. A színárnyalat értékei a vörös újboroknál jellemző értékeket mutatták (KÁLLAY 2010). PÁSTI (2002) szerint a sósav indexek a megfelelő tartományba esnek, azonban a zselatin index értékei elmaradnak az előzetesen várt szinttől (>40).

\begin{tabular}{cccc}
\hline Szüreti időpont & $\mathbf{2 0 1 1 . 0 9 . 1 3 .}$ & $\mathbf{2 0 1 1 . 0 9 . 2 7 .}$ & $\mathbf{2 0 1 1 . 1 0 . 1 0 .}$ \\
\hline Alkohol $(\mathrm{v} / \mathrm{v} \%)$ & $13,95 \pm 0,14 \alpha$ & $15,64 \pm 0,27 \beta$ & $16,50 \pm 0,17 \gamma$ \\
Extrakt $(\mathrm{g} / \mathrm{l})$ & $26,6 \pm 0,1 \alpha$ & $27,5 \pm 1,9 \alpha \beta$ & $32,6 \pm 0,9 \beta$ \\
Titrálható sav $(\mathrm{g} / \mathrm{l})$ & $6,5 \pm 0,3 \alpha$ & $5,9 \pm 0,1 \beta$ & $5,1 \pm 0,0 \beta$ \\
$\mathrm{pH}$ & $3,45 \pm 0,07 \alpha$ & $3,60 \pm 0,10 \alpha \beta$ & $3,77 \pm 0,13 \beta$ \\
Összes polifenol $(\mathrm{mg} / \mathrm{l})$ & $1566 \pm 59 \alpha$ & $1592 \pm 92 \alpha \beta$ & $1747 \pm 58 \beta$ \\
Leukoantocianin $(\mathrm{mg} / \mathrm{l})$ & $1950 \pm 92 \alpha$ & $2086 \pm 118 \alpha \beta$ & $2303 \pm 28 \beta$ \\
Antocianin $(\mathrm{mg} / \mathrm{l})$ & $484 \pm 17 \alpha$ & $690 \pm 48 \beta$ & $630 \pm 31 \beta$ \\
Katechin $(\mathrm{mg} / \mathrm{l})$ & $1352 \pm 21 \alpha$ & $694 \pm 127 \beta$ & $1233 \pm 109 \alpha$ \\
Színintenzitás $\left(\mathrm{A} 420+\mathrm{A}_{520}\right)$ & $21,13 \pm 2,22 \alpha$ & $20,27 \pm 1,92 \alpha$ & $19,45 \pm 1,16 \alpha$ \\
Színárnyalat $\left(\mathrm{A}_{420} / \mathrm{A}_{520}\right)$ & $0,42 \pm 0,02 \alpha$ & $0,58 \pm 0,06 \beta$ & $0,59 \pm 0,07 \beta$ \\
Sósav index $(\%)$ & $11,96 \pm 1,61 \alpha$ & $11,28 \pm 3,58 \alpha$ & $10,91 \pm 1,47 \alpha$ \\
Zselatin index $(\%)$ & $26,86 \pm 3,88 \alpha$ & $26,48 \pm 1,68 \alpha$ & $24,74 \pm 2,23 \alpha$ \\
\hline \multicolumn{4}{c}{ 7. táblázat - A $2011-e s$ kísérleti borok analitikája }
\end{tabular}

A különböző görög betükkel jelölt értékek, a szüreti időpontok közötti szignifikáns különbséget jelölik. Az összehasonlításokat $\mathrm{p}=0,05$ szinten végeztük. Minden érték az átlagot \pm a szórást jelenti. 
DOI: $10.14267 /$ phd.2015023

\subsection{A 2012-es és 2013-as borok analitikai paraméterei}

\subsubsection{Alapanalitikai eredmények}

\section{Alkoholtartalom}

A mustok cukortartalma alapján, a kontroll és a kezelt szőlőből készült borok alkoholtartalmában nagy eltérésre nem lehetett számítani. A borok között szignifikáns különbséget nem sikerült kimutatni (40. ábra). Az évjárathatás ellenben itt is igen jelentősnek bizonyult. A 2012-es évben már az első szüreti időpontból származó borok is a 14,5 v/v\%-os tartományban helyezkedtek el, míg 2013-ban a harmadik időpontban sem sikerült ezt az éréket elérni. Ráadásul ebben az évben a mintavétel, így a borkészítés is egy héttel későbbre tolódott. A 2012-es évjáratban, a szeptember végi szüretből származó kontroll és kezelt borok alkoholtartalma már egyaránt túl magas értéket ért el, hiszen jóval meghaladta a $15 \mathrm{v} / \mathrm{v} \%$-ot. Szükséges volt azonban kivárni a szürettel, mivel a szőlő a korábbi időpontokban, még nem érte el a kívánt fenolos érettséget. Ezzel szemben, a 2013-as év hűvösre, esősre fordult őszi időjárása, már sem a cukorképződésnek, sem pedig a fenolos érésnek nem kedvezett. 
DOI: $10.14267 /$ phd.2015023

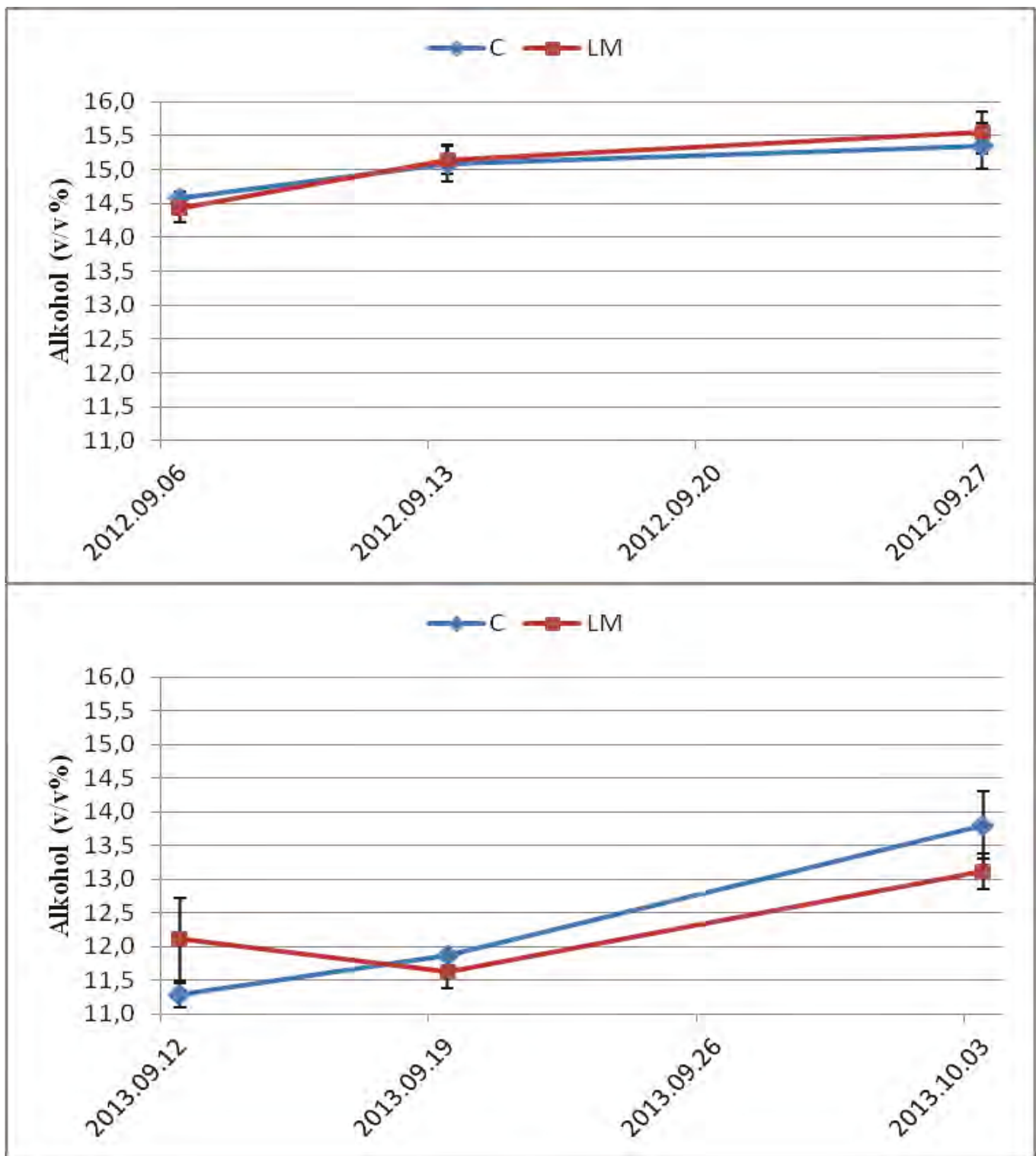

40. ábra - A kísérleti borok alkoholtartalmának alakulása 2012-ben és 2013-ban 


\section{Titrálható savtartalom}

A titrálható savtartalom, az évjáratokra jellemző sajátosságoknak megfelelően alakult, 2012-ben alacsonyabb, 2013-ban magasabb értékek jellemezték (41. ábra). A lombtrágya az első szüreti időpontokban mindkét évjáratban szignifikánsan alacsonyabb értékeket adott. A különbség 2013-ban a második bornál is megmaradt, azonban a harmadik szüreti időpontra mindkét évben eltünt.

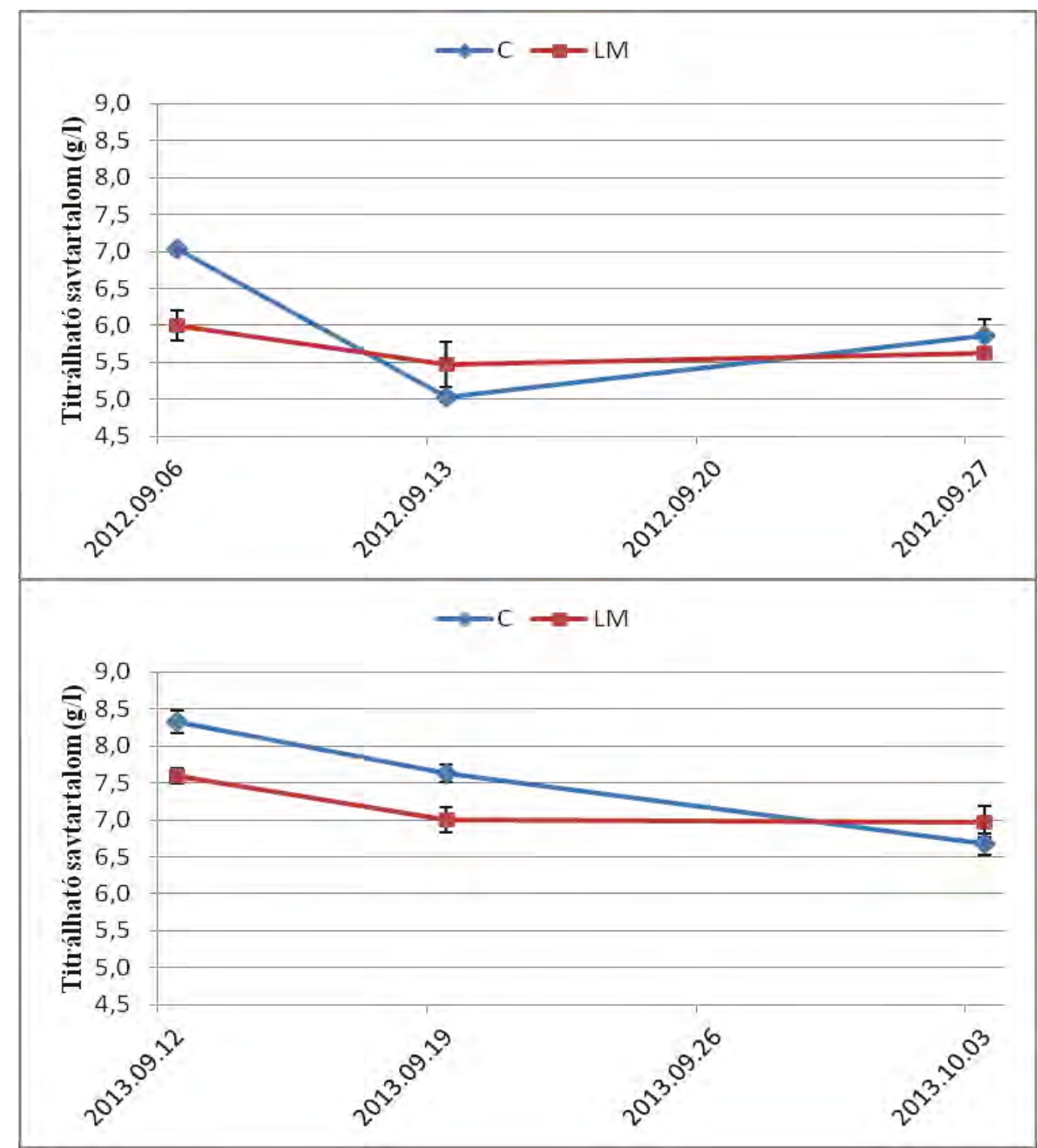

41. ábra - A kísérleti borok titrálható savtartalmának alakulása 2012-ben és 2013-ban 
pH

A borok pH-ja a 2013-as évjáratban az érés elörehaladtával csak igen kismértékben változott. A titrálható savtartalom magas értékei miatt, mindvégig 3,2 alatt maradt, mind a kontroll, mind a kezelt boroknál. Ezzel szemben 2012-ben az utolsó kontroll bornál, extrém magas, 3,86-os pH értéket mértünk, de a kezelt is majdnem elérte a 3,7-es tartományt. Szignifikáns különbséget 2012-ben a második, 2013-ban a harmadik szüreti időpontból származó borok között nem sikerült kimutatni, a többi időpontban viszont igen (42. ábra).

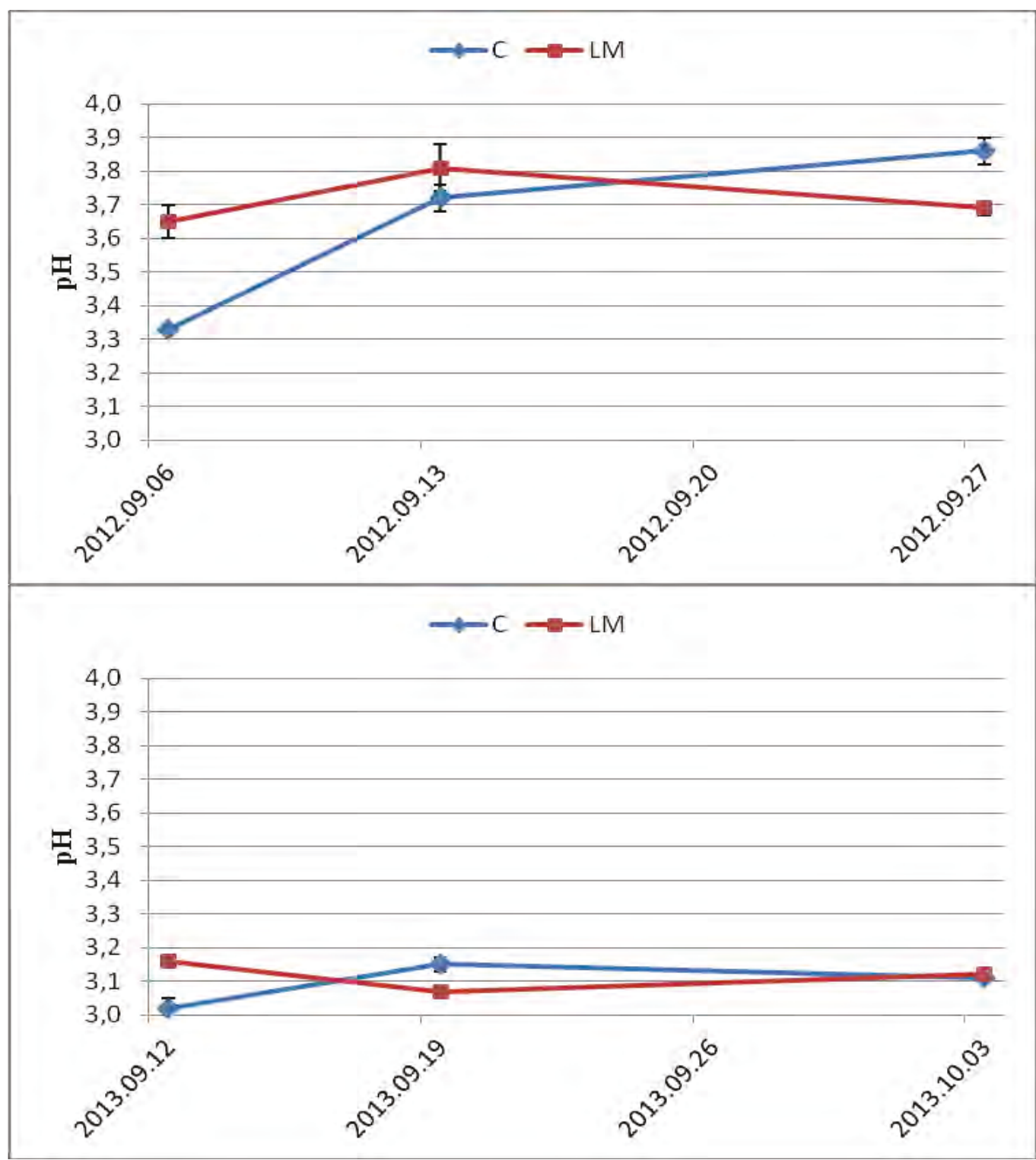

42. ábra - A kísérleti borok pH-jának alakulása 2012-ben és 2013-ban 


\section{Cukormentes extrakttartalom}

Megállapítható, hogy a borok cukormentes extrakttartalmára sem a kezelés, sem az évjárat nem gyakorolt hatást (43. ábra).

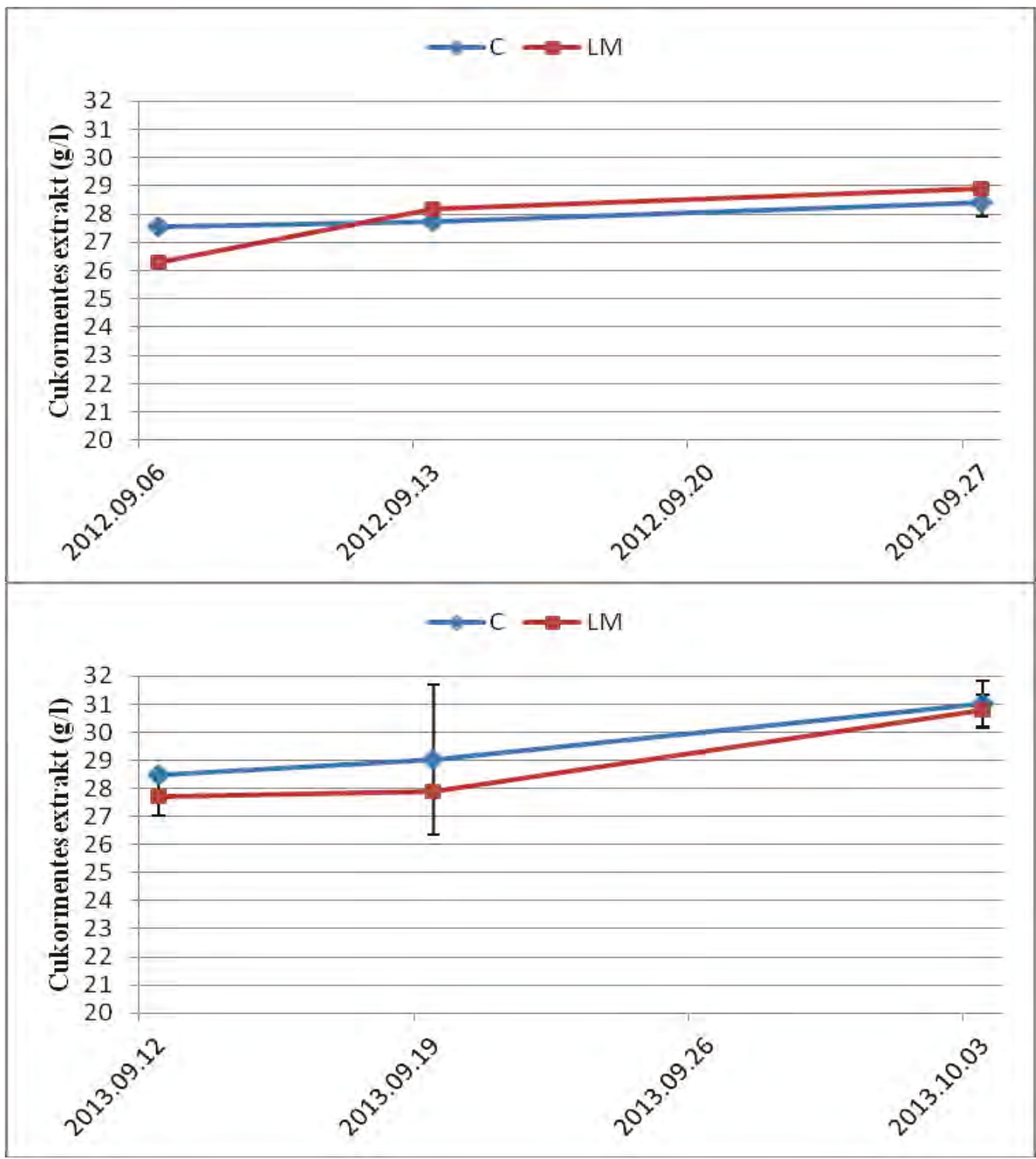

43. ábra - A kísérleti borok cukormentes extrakttartalmának alakulása 2012-ben és 2013-ban 
DOI: $10.14267 /$ phd.2015023

\subsubsection{Polifenoltartalom}

\section{Összes polifenoltartalom}

Ennél a paraméternél is az évjárathatás volt az a változó, amely a legnagyobb befolyást gyakorolta az értékekre. A 2013-as évjáratban határozottan kevesebb polifenol termelődött, mint az azt megelöző évben. A kezelések között szignifikáns különbséget csak a 2012-es évjárat harmadik boránál tapasztaltam, itt a kezelésben részesült borokban alakultak ki magasabb értékek (44. ábra). Az összes polifenoltartalom értékei valószínűleg azért nem változtak már érdemben a kezelés hatására, mivel ezen vegyületek jelentős hányadának a kialakulása a zsendülés kezdetéig már nagyobb részben végbe mehetett (CHEYNIER et al. 1997; DE FREITAS ÉS GLORIES 1999; KENNEDY et al. 2001; HARBERTSON et al. 2002; DOWNEY et al. 2003; CADOT et al. 2006).

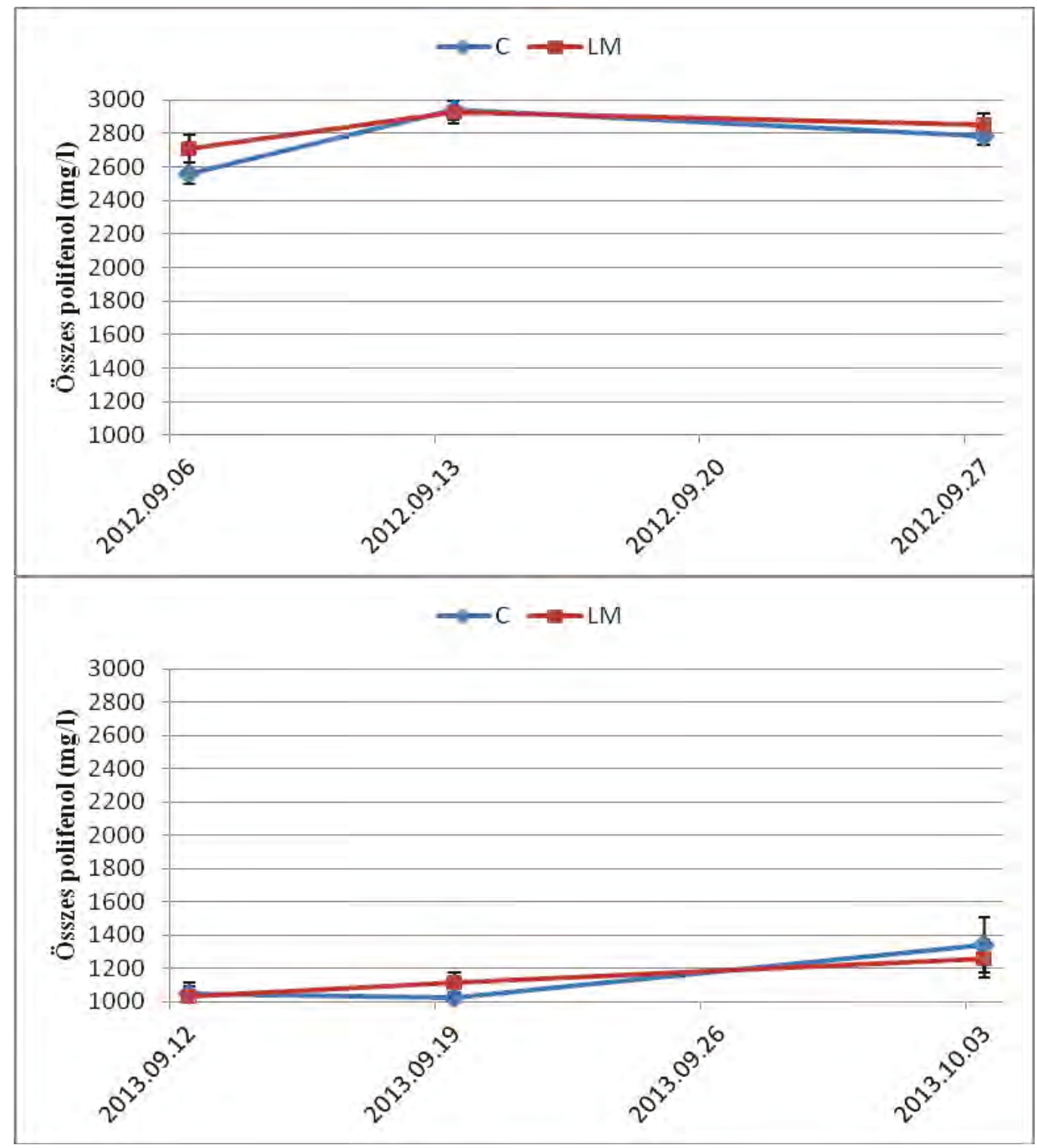

44. ábra - A kísérleti borok összes polifenoltartalmának alakulása 2012-ben és 2013-ban 


\section{Leukoantocianintartalom}

A lombtrágya használata, a leukoantocianinok mennyiségét, a 2012-es évjárat első borát leszámítva nagymértékben megnövelte, bár a különbség csak a 2012. év második és harmadik szüreti időpontból származó bortételeinél volt szignifikáns. Az évjárat hatása, erre a fenolos vegyületcsoportra kisebb mértékü volt, mint az összes polifenoltartalomnál tapasztalt. KÁLLAY (2010) szerint a vörösborok leukoantocianintartalma általában $2 \mathrm{~g} / 1$ körüli. A kísérleti boraim, ezen a tartományon belül találhatóak (45. ábra).

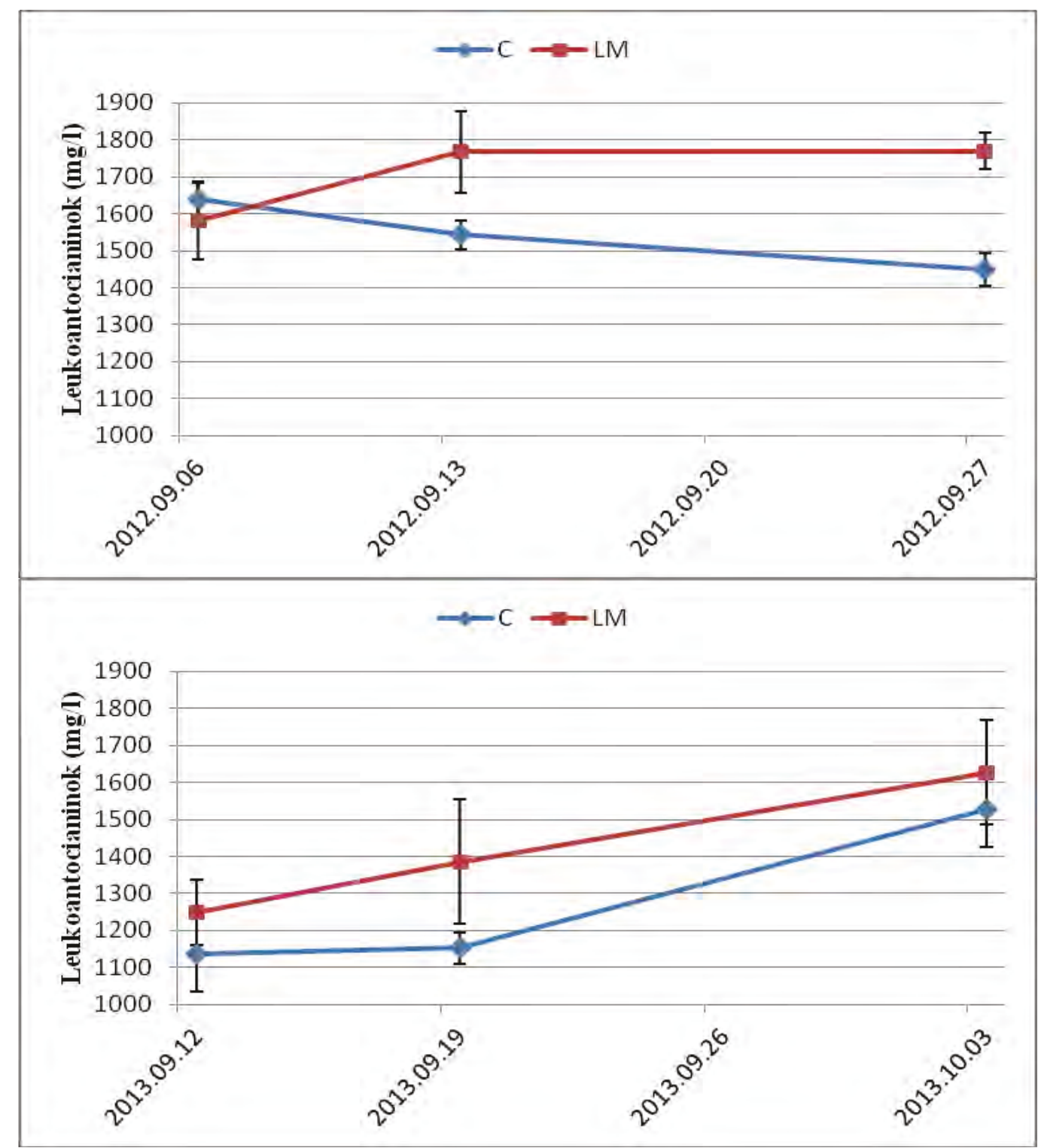

45. ábra - A kísérleti borok leukoantocianintartalmának alakulása 2012-ben és 2013-ban 


\section{Antocianintartalom}

Az antocianinok mennyisége a kezelt bortételek mindegyikében magasabb volt, mint a kontroll esetében (46. ábra). Az eredmények összhangban vannak a lombtrágyázott szőlőbogyókból kivont színanyagok mennyiségével (32. ábra). A lombtrágya antocianin termelődést elősegítő hatása mindkét évben érvényesült. A kezelőanyag alkalmazásán túl, az évjárat befolyása ennél a fenolos vegyületcsoportnál kifejezetten erős volt. Ezt a jelenséget már korábban is megfigyelték (GUIDONI et al. 2008). A kedvezőtlenebb időjárású 2013-as évet hüen tükrözik vissza a jelentősen alacsonyabb értékek. 2012-ben, az antocianinok borban található mennyisége hamar elérte a csúcspontot, hiszen a harmadik szüreti időpontra már csökkenésbe kezdett, akárcsak a szőlőkivonatok esetében. A csökkenés két dologra vezethető vissza. Az egyik, hogy a szőlő elérte a túlérettség állapotát és a színanyagok lebomlása megindult (FOURNAND et al. 2006), a másik, hogy a héj sejtfalának összetétele, szerkezete olyan változáson ment át, amely a kivonhatóságot csökkentette (ROMERO-CASCALES et al. 2005; ORTEGAREGULES et al. 2006). A kezelés hatása két esetben volt szignifikáns, mindkét évjárat második szüretből származó borai esetében. 
DOI: $10.14267 /$ phd.2015023

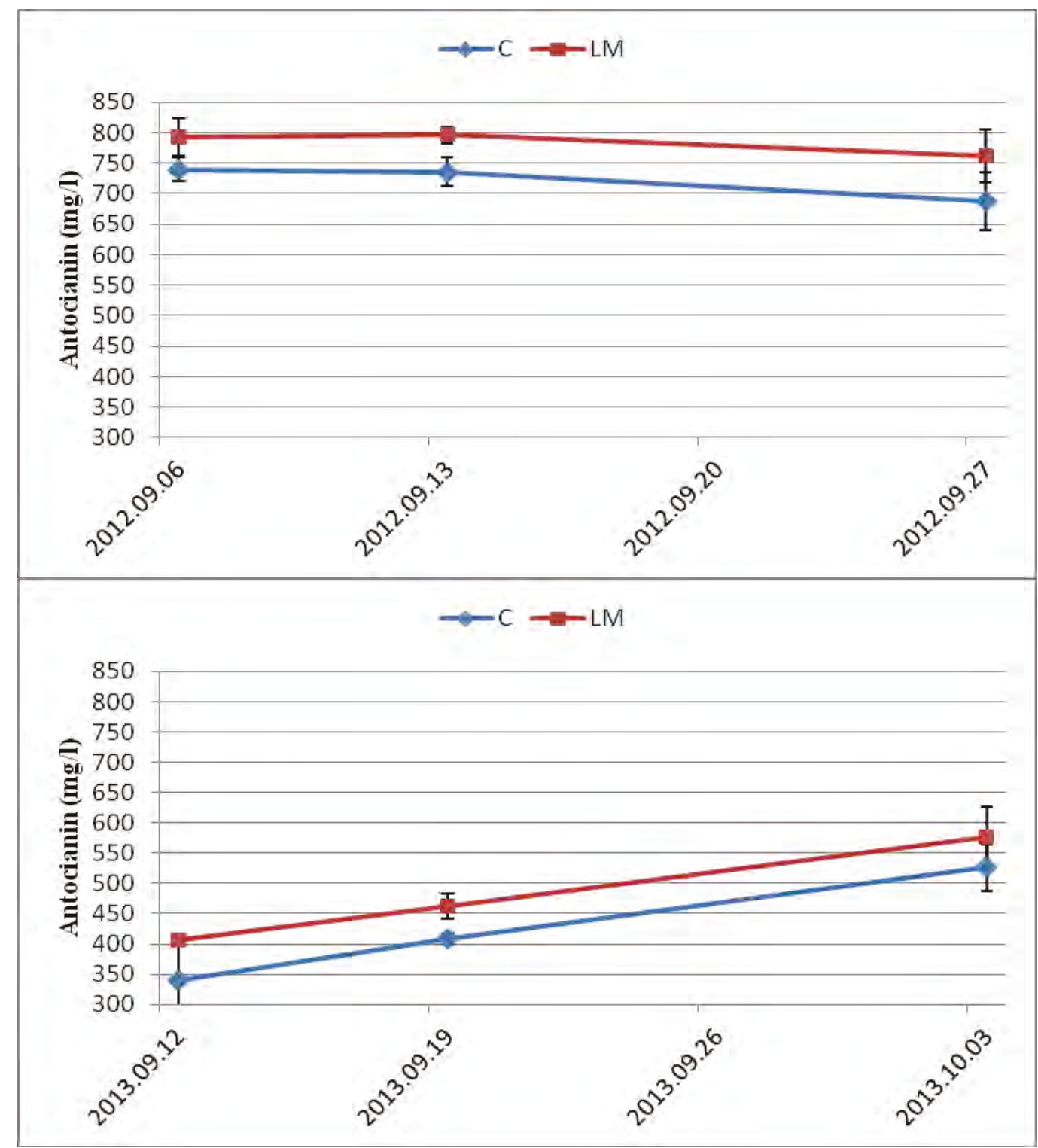

46. ábra - A kísérleti borok antocianintartalmának alakulása 2012-ben és 2013-ban 


\section{Katechintartalom}

Az alkalmazott kezelés hatása a katechinek mennyiségének alakulására, a kapott eredmények ismeretében nem egyértelmü (47. ábra). A 2012-es szüret első és második borában a katechinek mennyisége még alacsonyabb volt a kezelés hatására (a különbség szignifikáns). Az utolsó szüreti időpontra azonban az eltérések eltűntek. 2013-ban a második szüreti időpontban viszont magasabb értékeket mértünk a kezelt borok esetében. A különbség itt is szignifikáns volt. Ebben az évben, az első és a harmadik szüretelésü, kontroll és kezelt borok katechintartalma megegyezőnek tekinthető.

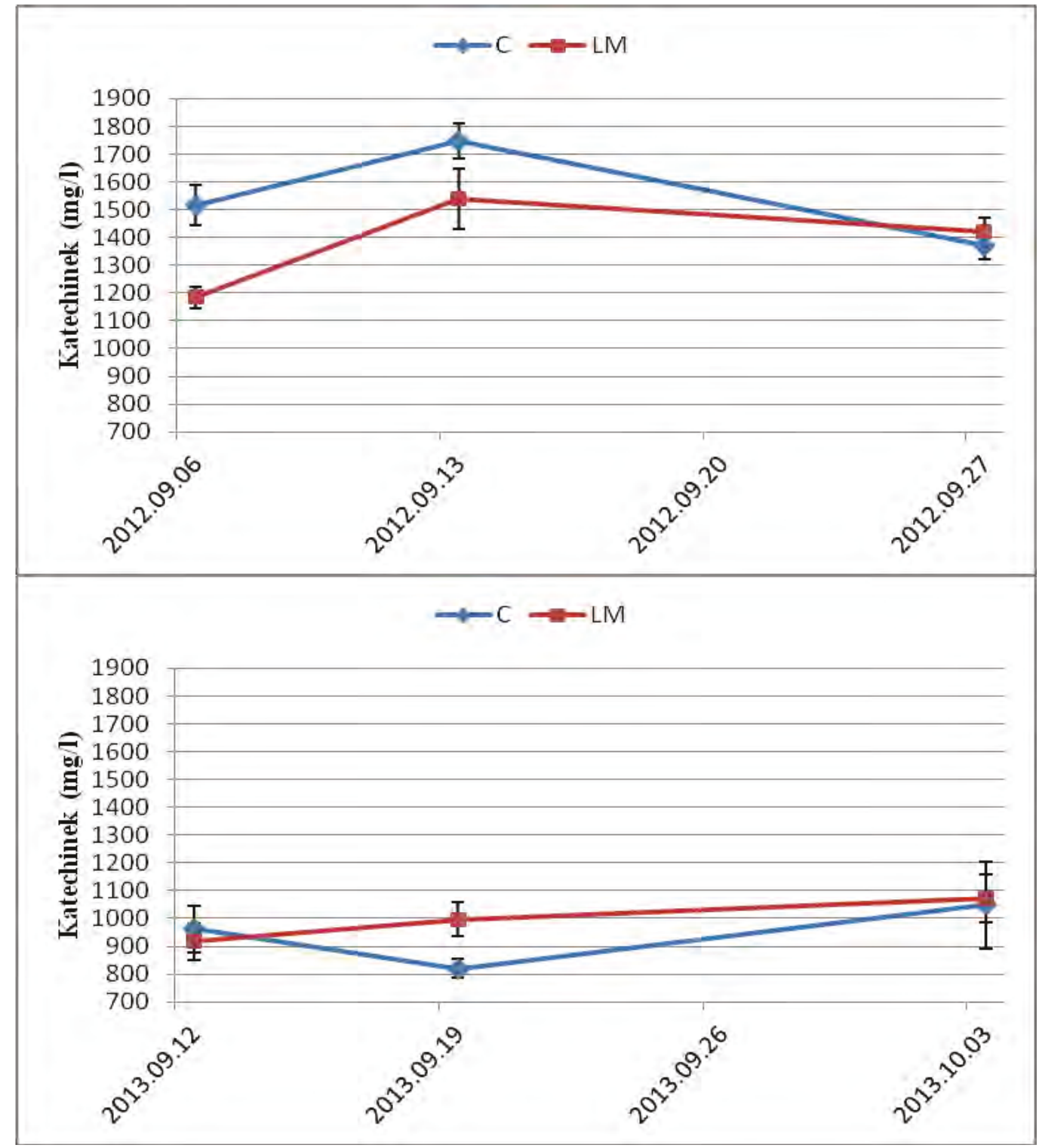

47. ábra - A kísérleti borok katechintartalmának alakulása 2012-ben és 2013-ban 


\section{Színintenzitás és színárnyalat}

A borok színintenzitása és antocianintartalma között egyenes arányosság állt fenn. A magasabb értékekhez minden esetben intenzívebb szín tartozott (48. ábra). A lombtrágyával kezelt szőlőből készült borok magasabb színintenzitás értéke 2012-ben a második és a harmadik szüretből származó bor esetében, míg 2013-ban az első bornál volt szignifikáns. Megállapítható, hogy a kapott értékek rendkívül magasnak bizonyultak. A KÁLLAY (2010) által megadott színintenzitás értékskála alapján, a 2013-es évjárat első két kontroll borát leszámítva, minden bor a „kiváló festőbor” kategóriába tartozik (színintenzitás $>20$ ). Tekintettel arra, hogy a Syrah nem festőlevü fajta, ez kiemelkedő.

A 2012-es borok színárnyalatai elfogadhatók, ugyanis 0,50 és 0,80 közé esnek (KÁLLAY 2010) (49. ábra). Az értékek 2013-ban azonban 0,50 alatt maradtak. Ez a fiatal vörösborokra (a Syrah fajtára) kifejezetten jellemző erőteljes kékes, lilás színárnyalatra vezethető vissza (BOULTON 2001). 
DOI: $10.14267 /$ phd.2015023

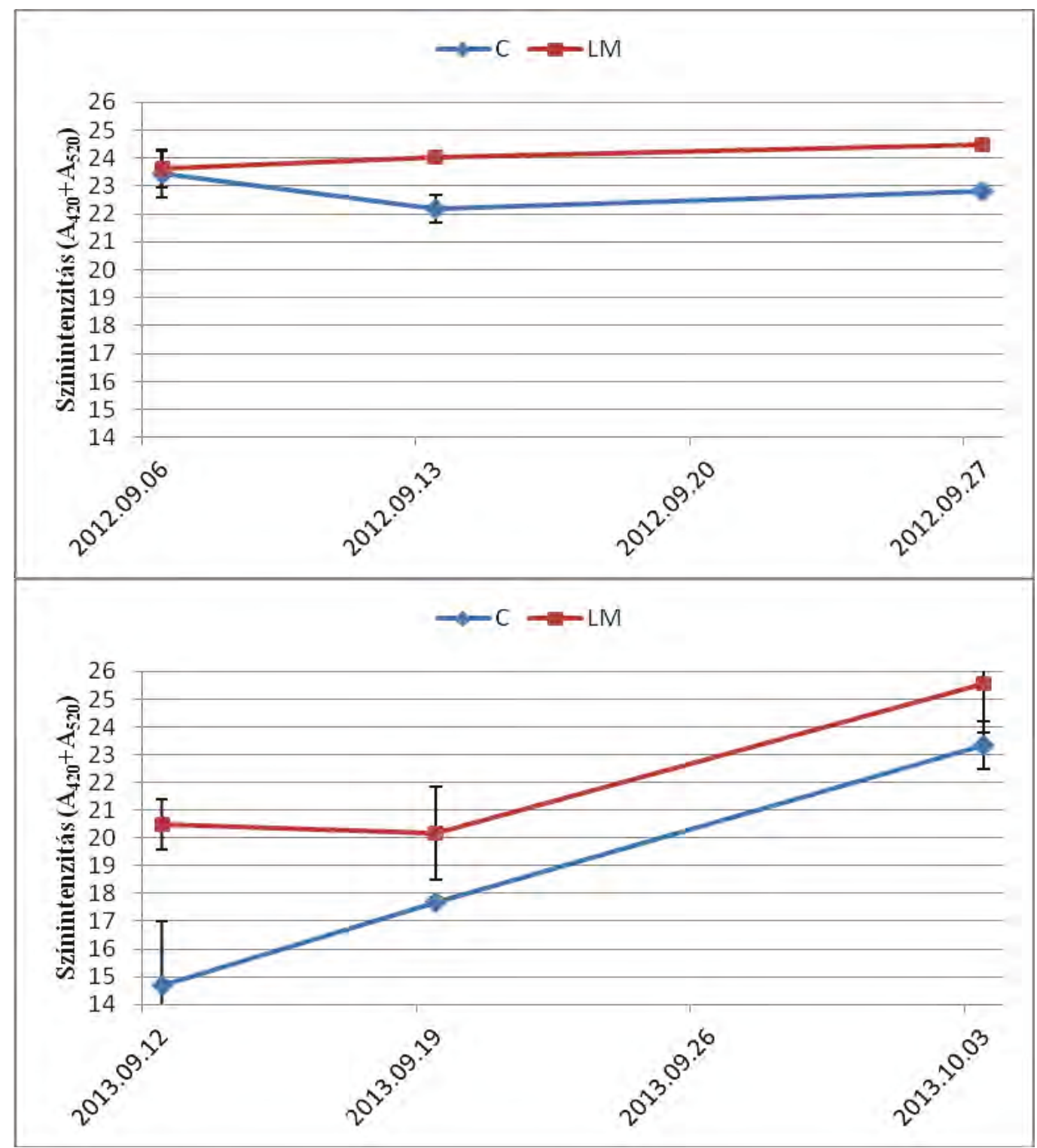

48. ábra - A kísérleti borok színintenzitásának alakulása 2012-ben és 2013-ban 
DOI: $10.14267 /$ phd.2015023

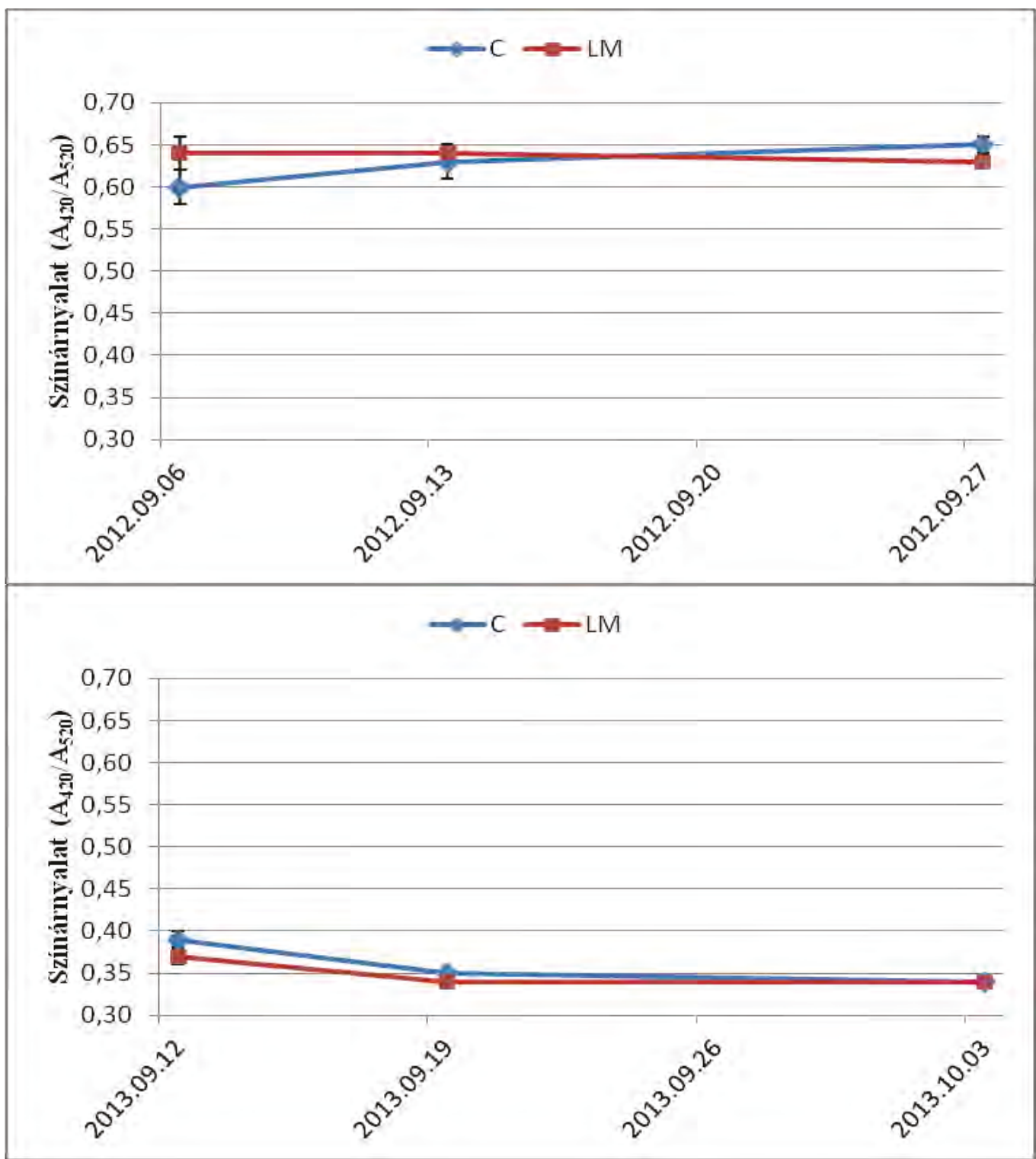

49. ábra - A kísérleti borok színárnyalatának alakulása 2012-ben és 2013-ban 


\section{Sósav index $(\mathrm{HCl})$}

A sósav index mérésének alapja, hogy a procianidinek savas közegben instabillá válnak. A kicsapódás sebessége a polimerizációs fok függvénye (PÁsTI 2002). Az újborokra jellemző értékek általában 5 és 10 közé esnek. A borok érlelése során az index növekszik. A lombtrágya hatására a kísérleti borok sósav indexében két esetben történt szignifikáns növekedés, ami polimerizáltabb, érettebb tanninokat jelez. Ez a megállapítás a 2012-es évjárat második és a 2013-as évjárat harmadik borára teljesült, az évjárathatás azonban minden esetben jelentkezett (50. ábra).

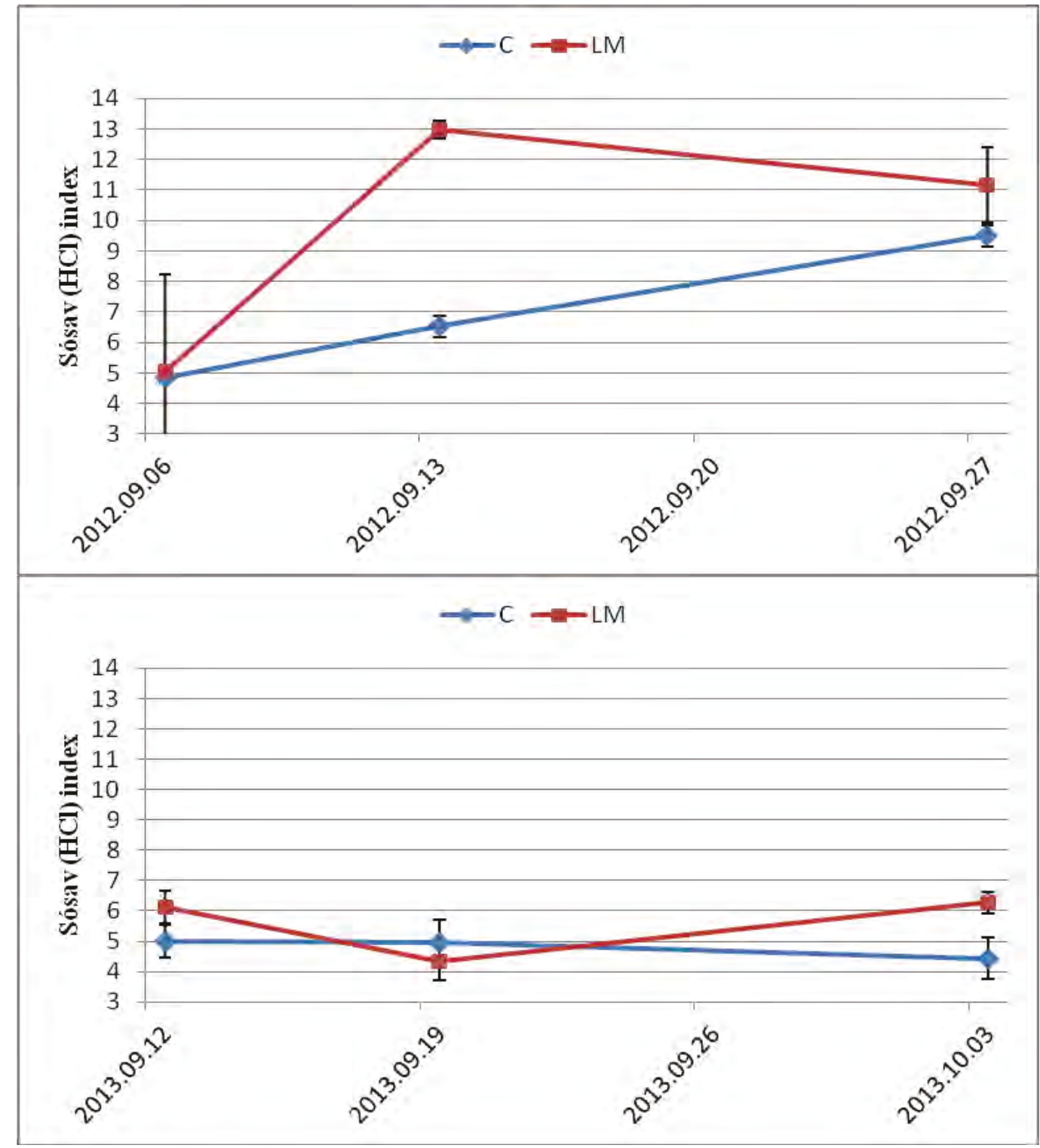

50. ábra - A kísérleti borok sósav (HCl) indexének alakulása 2012-ben és 2013-ban 


\section{Zselatin index}

A tanninok kondenzáltságuktól függően, eltérő módon lépnek reakcióba a fehérjékkel. A kondenzált tanninok a hozzáadott zselatinnal stabil vegyületet képeznek, majd kicsapódnak. A zselatin index a tanninok reakcióképességét mutatja meg, amely szoros összefüggést mutat a húzósság érzettel a szájban. Az index értéke általában 25-80 között mozog (PÁSTI 2002). A 60 feletti értékek durva, húzós tanninérzetü borokra utalnak, ezzel szemben 35 alatt a borok nem rendelkeznek kellő tartással, üresek, keserüek lehetnek. 40 és 60 között található az a tartomány, amely kellően beérett, bársonyos tanninú, érlelésre alkalmas vörösborokat jelent. A 2012-es évjárat borai kivétel nélkül ebbe a kategóriába tartoztak. Az első és harmadik szüreti időpontból származó borok esetében a lombtrágya szignifikánsan magasabb zselatin indexet hozott, amely kedvezőbb tanninstruktúrára, ezáltal jobban érlelhető, értékesebb borra utal. A magasabb értékkel rendelkező boroknak a bírálók minden esetben magasabb pontszámot adtak. Érdekes módon a 2013-as év első szüretének borai esetében, még a kontroll boroknál volt magasabb a zselatin index értéke, majd a következő két bornál a lombtrágya hatása elkezdett érvényesülni és megfordult az irány. A harmadik időpontra a kezelt borokban már szignifikánsan magasabb volt a zselatin index, igaz hogy csak 0,7 tizeddel. A 2013-as év borainak zselatin indexei, az évjárathatás miatt nagyságrendekkel alacsonyabb értékekben nyilvánultak meg, mint 2012-ben. A 2013-as évjárat borairól összességében kijelenthető, hogy tanninszerkezetük nem megfelelő, érlelésre nem igazán alkalmasak (51. ábra). Ezt a megállapítást az érzékszervi bírálat is alátámasztotta, hiszen a borok kóstolásakor megjelent a fenolos érettség hiányára utaló éretlen és húzós érzet. 
DOI: $10.14267 /$ phd.2015023

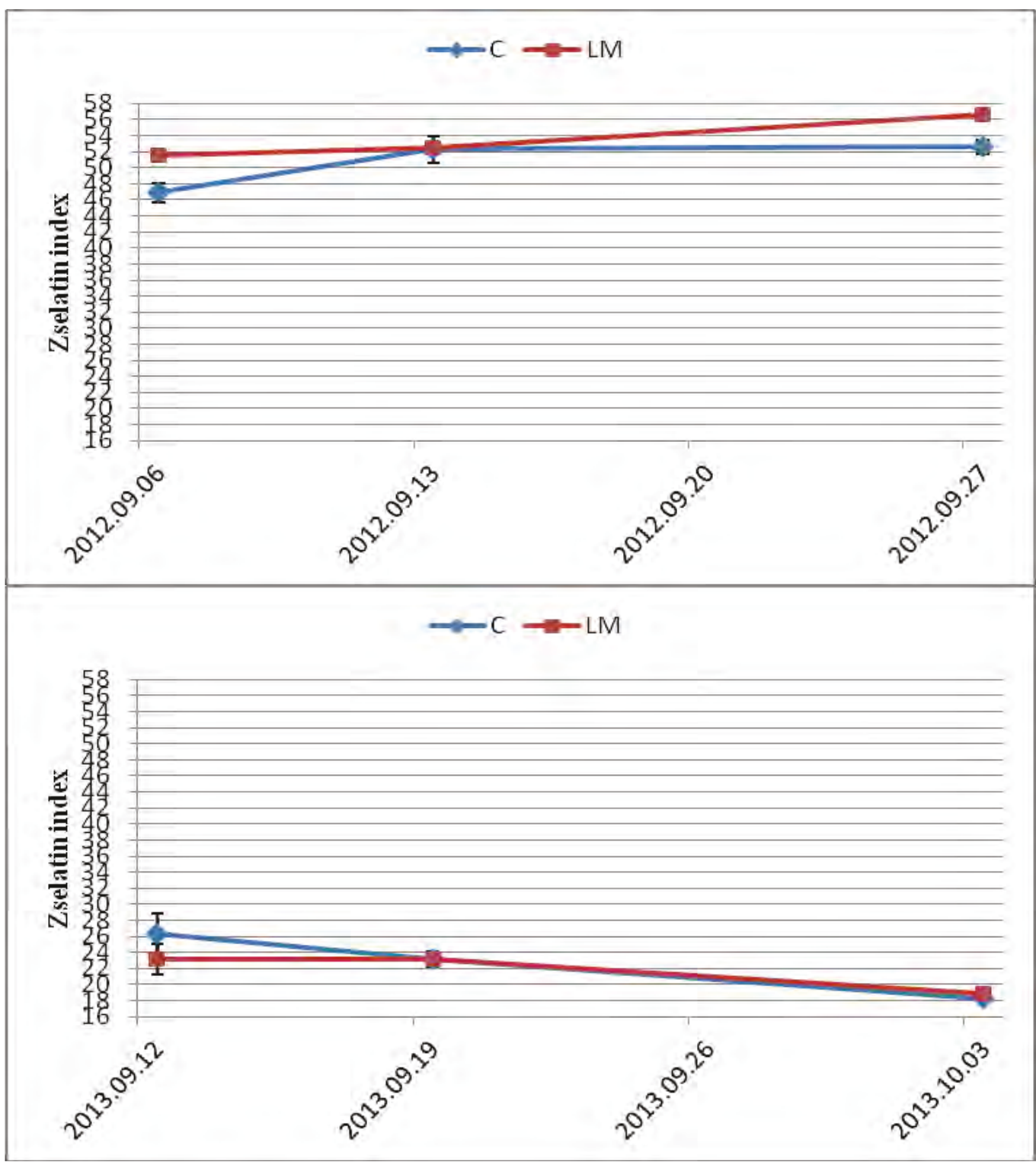

51. ábra - A kísérleti borok zselatin indexének alakulása 2012-ben és 2013-ban 


\subsubsection{Sztilbének}

\section{A 2011-es borok rezveratroltartalma}

A borok transz-rezveratrol, cisz-rezveratrol tartalma növekvő, míg a transz-piceid és ciszpiceid tartalom csökkenő tendenciát mutatott az érettségi fok elörehaladtával (8. táblázat). Ez összhangban van azzal a megállapítással, hogy az egészséges szőlőbogyóban, az összes rezveratroltartalom nagy része, főként piecid alakban fordul elő és a borkészítés során alakul át rezveratrollá (MATTIVI et al. 1995). Ha a négy vegyület összegét vesszük, akkor szüreti időpontról szüreti időpontra egyértelmü növekedésről lehet beszámolni.

\begin{tabular}{cccc}
\hline Szüreti időpont & $\mathbf{2 0 1 1 . 0 9 . 1 3 .}$ & $\mathbf{2 0 1 1 . 0 9 . 2 7 .}$ & $\mathbf{2 0 1 1 . 1 0 . 1 0 .}$ \\
\hline Transz-rezveratrol (mg/l) & $0,23 \pm 0,12 \alpha$ & $4,24 \pm 0,43 \beta$ & $4,89 \pm 1,10 \beta$ \\
Cisz-rezveratrol (mg/l) & $0,02 \pm 0,04 \alpha$ & $0,04 \pm 0,07 \alpha$ & $0,16 \pm 0,16 \beta$ \\
Transz-piceid (mg/l) & $2,13 \pm 0,81 \alpha$ & $0,11 \pm 0,10 \beta$ & $0,37 \pm 0,19 \beta$ \\
Cisz-piceid (mg/l) & $1,73 \pm 0,21 \alpha$ & $0,06 \pm 0,10 \beta$ & n.d. \\
Összesen $(\mathrm{mg} / \mathrm{l})$ & $4,12 \pm 0,90 \alpha \beta$ & $4,45 \pm 0,36 \alpha \beta$ & $5,42 \pm 0,92 \gamma$ \\
\hline
\end{tabular}

8. táblázat - A 2011-es kísérleti borok rezveratroltartalma, n.d. = nem detektálható

A különböző görög betükkel jelölt értékek, a szüreti időpontok közötti szignifikáns különbséget jelölik. Az összehasonlításokat $\mathrm{p}=0,05$ szinten végeztük. Minden érték az átlagot \pm a szórást jelenti.

\section{A kísérleti borok rezveratroltartalmának alakulása a 2012-es és a 2013-as évjáratban}

A 2012-es és 2013-as borminták egyike sem tartalmazott cisz-rezveratrolt.

\section{Transz-rezveratrol}

Az első szüreti időpontból származó kontroll borok egyike sem tartalmazott transzrezveratrolt (52. ábra). Ezt a vegyületet ekkor még, a kezelt borokban is csak nagyon kis mennyiségben lehetett kimutatni. A következő két időpont mintái esetében már a kontroll borokban is megjelent, sőt nagyobb mennyiségben is tartalmazta a kezeltekhez képest, bár a különbség csak a 2012-es évjárat második borai között volt szignifikáns. A szőlőbogyó héjában a sztilbének főként piceid alakban fordulnak elő a leggyakrabban, míg a borokban általában a rezveratrol forma a domináns (KÁLLAY 2010). 


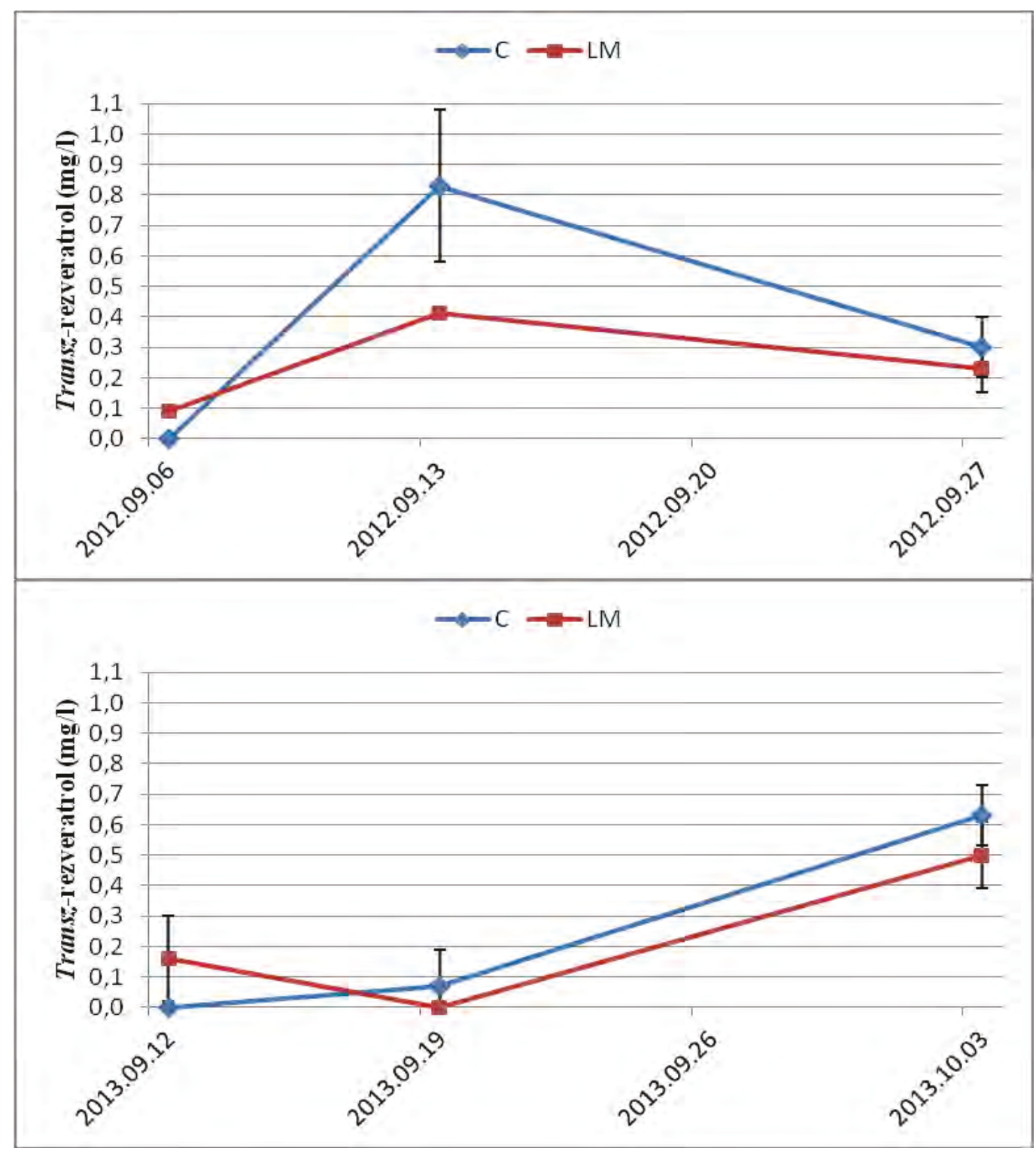

52. ábra - A kísérleti borok transz-rezveratrol tartalmának alakulása 2012-ben és 2013-ban

\section{Transz-piceid}

A 2012-es évjárat első és második szüretelésű, lombtrágyázott szőlőből készült borának transz-piceid tartalma, a kontrollhoz képest szignifikánsan magasabb volt. A 2013-ban az értékek az első két időpontban jóval alacsonyabbak voltak, mint az azt megelőző évben. Statisztikailag kimutatható különbség ebben az évben csak a második borok között volt. Ekkor a kontroll bor transz-piceid tartalma volt a magasabb (53. ábra). 
DOI: $10.14267 /$ phd.2015023

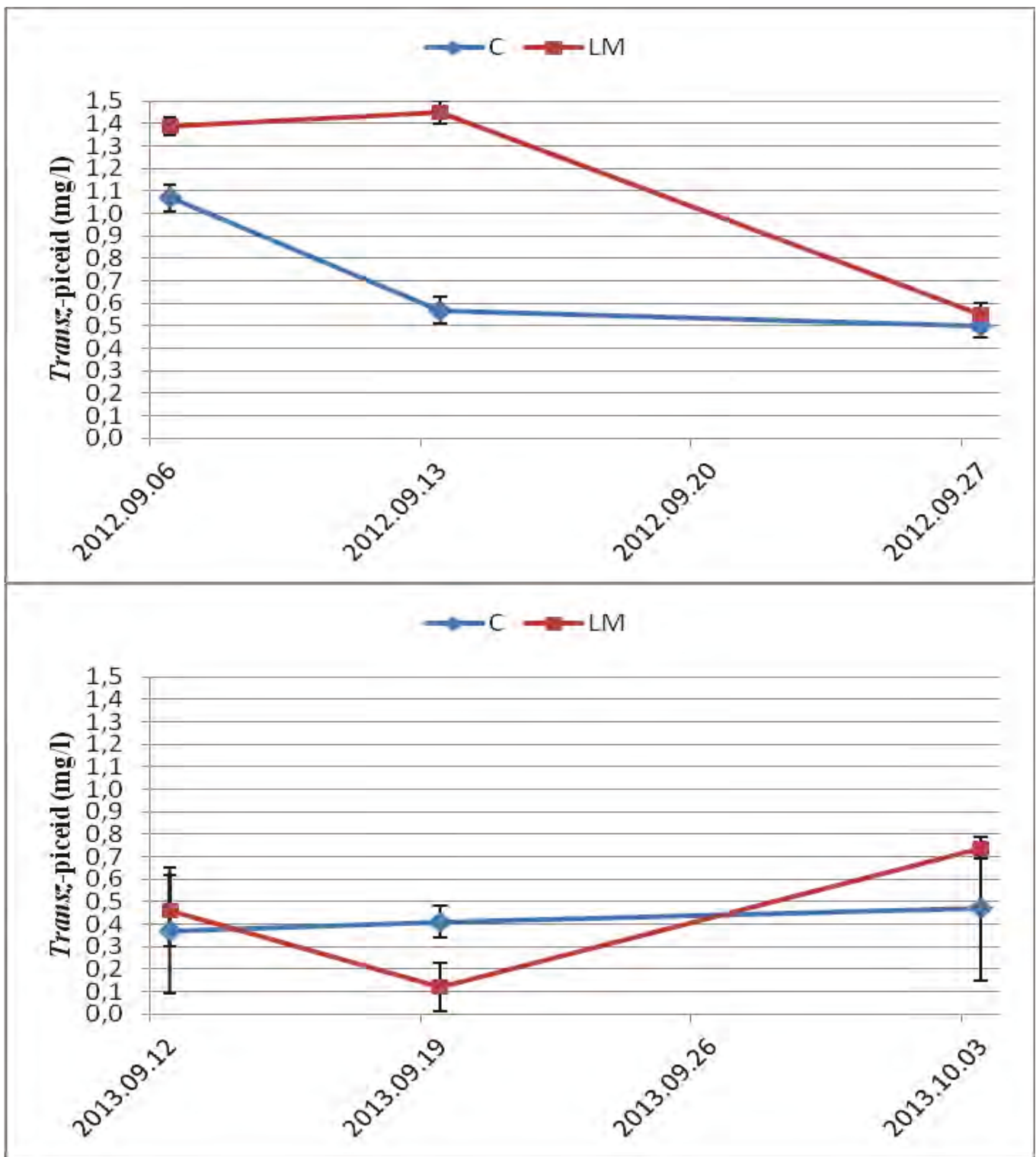

53. ábra - A kísérleti borok transz-piceid tartalmának alakulása 2012-ben és 2013-ban

\section{Cisz-piceid}

A 2012-es évjárat első szüretből származó kezelt bora, csaknem 1 mg/l mennyiségben tartalmazott cisz-piceidet, ezzel szemben a kontroll borokban egyáltalán nem volt kimutatható. Ugyanakkor a második és harmadik időpontra, már a kontroll mintákban mutattunk ki több cisz-piceidet, de a különbség csak az utolsó időpontban volt szignifikáns.

A 2013-as mérések sokkal egyöntetübb tendenciát mutattak. Mindhárom időpontban a kezelt borok tartalmaztak több cisz-piceidet, azonban a különbség csak a második bornál volt jelentős (54. ábra). 
DOI: $10.14267 /$ phd.2015023

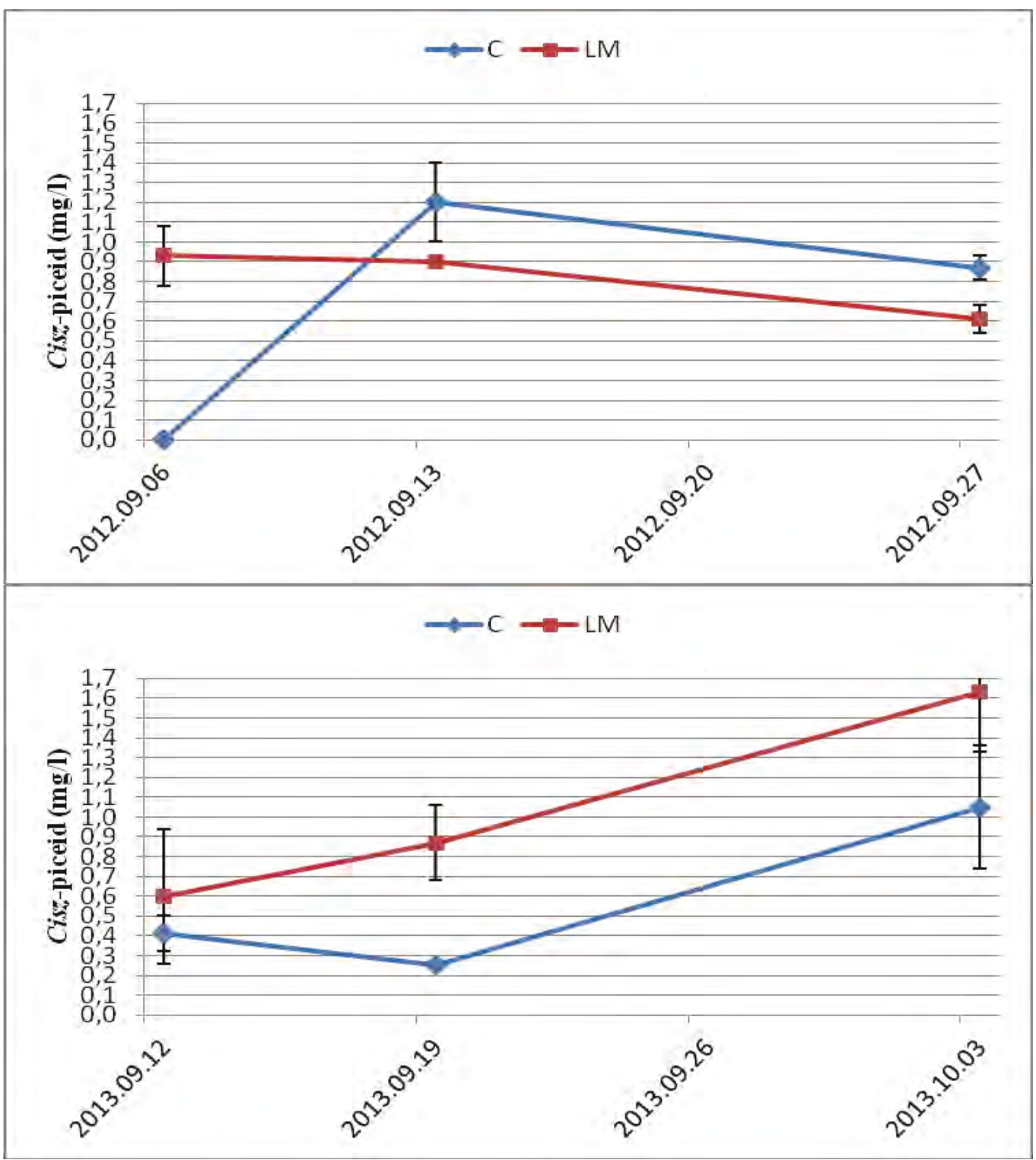

54. ábra - A kísérleti borok cisz-piceid tartalmának alakulása 2012-ben és 2013-ban 


\section{Összes rezveratroltartalom}

Mivel a lombtrágya hatása nem egyértelmü az egyes rezveratrol alkotók mennyiségi alakulására, ezért ezek összegét is szükséges megvizsgálni. A 2012-es évjárat első időpontban, lombtrágyát kapott szőlőből készült bora egyértelmüen több rezveratrolt tartalmazott, mint a kontroll. A különbség a következő két időpontra eltünt, sőt az utolsó időpontban már a kontroll borok tartalmaztak valamivel több rezveratrolt, bár a különbség nem volt szignifikáns (55. ábra). A 2013-as évjáratban már minden időpontban, a kontroll borokban volt egyértelmüen több rezveratrol. Statisztikailag kimutatható különbséget, az első és a harmadik szüretből származó borok között is sikerült megállapítani. Összegzésképpen megállapítható, hogy a kísérleti borok összes rezveratroltartalma, mindkét évben a hazai vizsgálatok alapján átlagos értéket ért el (KÁllay ÉS NYITRAinÉ SÁRdy 2007; KÁLlAy et al. 2009; KÁLlAY ÉS NYITRAINÉ SÁRDY 2009).

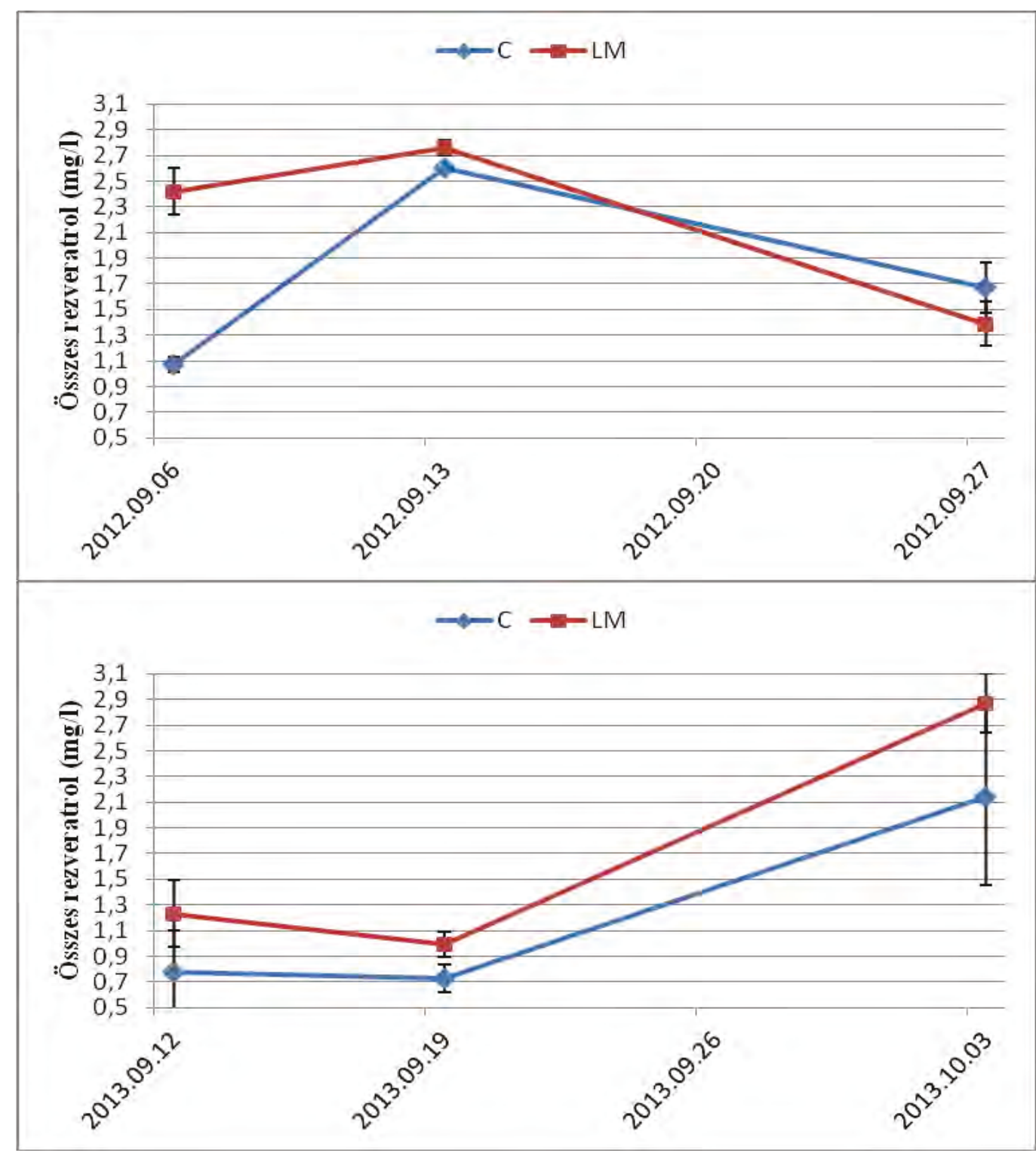

55. ábra - A kísérleti borok összes rezveratroltartalmának alakulása 2012-ben és 2013-ban 
DOI: $10.14267 /$ phd.2015023

\subsection{A borok érzékszervi bírálata és a kapott eredmények értékelése profilanalizissel}

\subsubsection{A 2011-es évjárat}

Mivel a 2011-es évjáratban lombtrágyás kezelés még nem volt beállítva, így az érzékszervi bírálaton a három különböző szüreti időpontból (szeptember 13., szeptember 27. október 10.) származó bor került bemutatásra (56. ábra). Ezek érzékszervi jellemzőit közösen ábrázolom és mutatom be.

A kiváló évjáratban kiváló borok születtek. Mindhárom borra jellemző volt a rendkívül mély, kékes-lilás árnyalatú szín, az aromagazdagság, a hatalmas test, a magas alkohol, a koncentrált íz és a hosszú lecsengés. A bírálók, a három tételt egyszerre, de vakon kóstolták, így lehetőség volt a borok egymással történő objektív összehasonlítására. Az első két szüreti időpontból származó bor értékelése próbára tette a bírálókat, ugyanis a két tétel sok tekintetben hasonlított egymásra. Ennek ellenére mindenkinek sikerült eltalálni a megfelelő szüreti sorrendet. Ha kicsivel is, de a második szüreti időpontból származó bor teltebb, testesebb és kicsivel hosszabb lecsengésű volt, mint az első. Ízében több gyümölcsöt és selymesebb tanninokat mutatott. Az első borban egy enyhe zöldes, nyers illat is megjelent, amit a többség füszeresként írt le. A harmadik szüreti időpontból származó bor magasan a legjobb pontszámokat kapta és mindenki ezt a bort választotta a sor legjobbjának. Érdekesség, hogy a nagyon magas alkohol $(16,50 \mathrm{v} / \mathrm{v} \%)$ nem volt túlzottan bántó, köszönhetően a kiemelkedő beltartalomnak (7. táblázat). A fenolos érettség, azonban még ilyen extrém analitikai paraméterek mellett sem volt teljes (zselatin index: 24,74). A Syrah fajtára legjellemzőbb karaktert, aromákat és füszerességet, ugyanakkor ez a harmadik bor képviselte leginkább. 


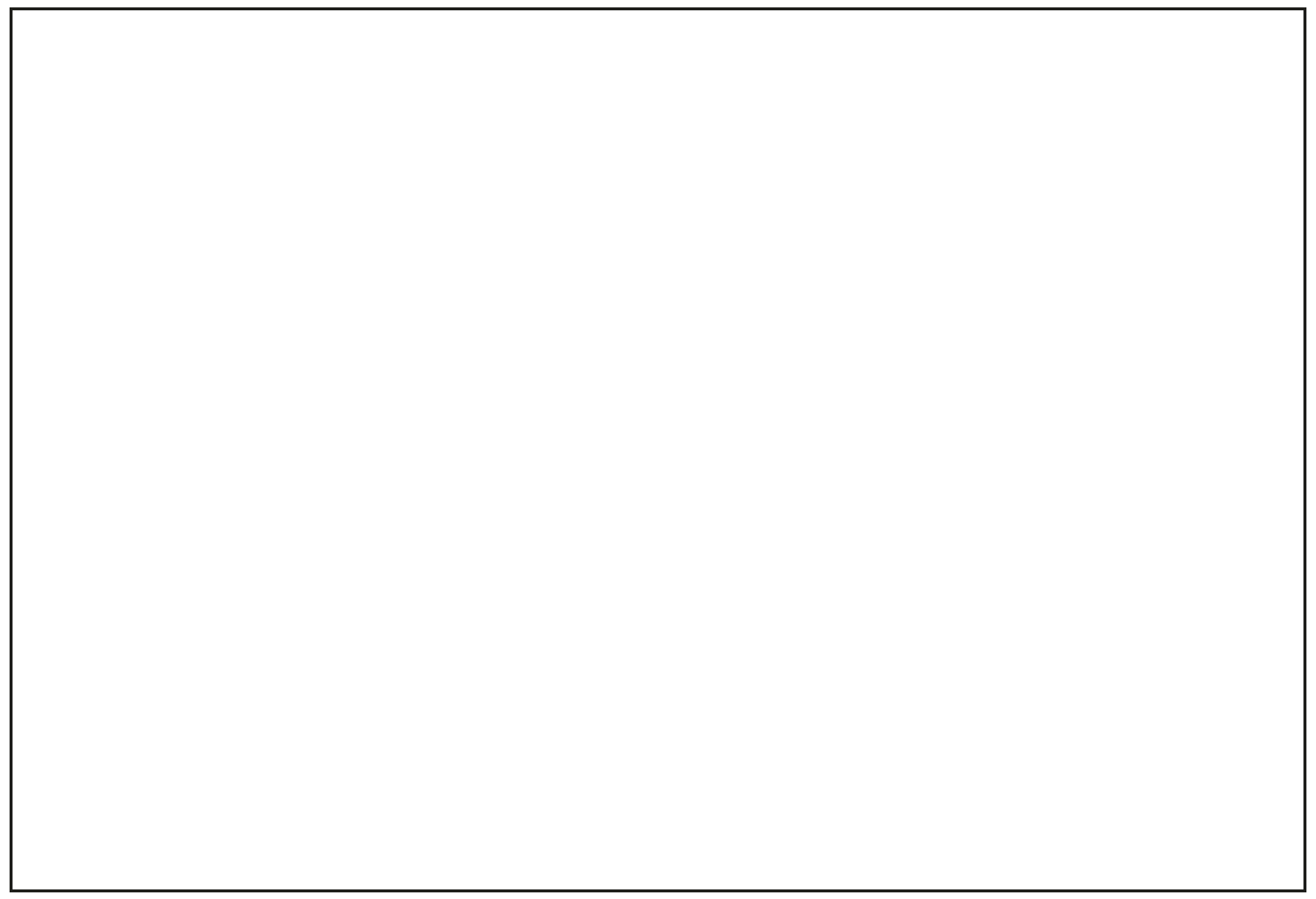

56. ábra - A 2011-es kísérleti borok profilanalízise 


\subsubsection{A 2012-es évjárat}

\section{Első szüreti időpont}

A könnyebb áttekinthetőség érdekében a 2012-es és a 2013-as évjárat borait, szüreti időpontonként, párban (kontroll (C) - kezelt (LM)) mutatom be.

A lombtrágya hatása szinte minden érzékszervi tulajdonságban megnyilvánult. A bírálók egyöntetüen a lombtrágyás kezelést kapott szőlőből készült bort tartották jobbnak. A legnagyobb különbség a sav- és a húzósság érzetben mutatkozott. A kezelt borok jóval lágyabb savakat, bársonyosabb tanninokat mutattak, valamint nagyobb egyensúllyal rendelkeztek és a fajtára jellemző jegyeket is jobban hozták (57. ábra). A bársonyosabb érzetet a magasabb zselatin index is alátámasztja (51. ábra).

57. ábra - A 2012-es évjárat első szüreti időpontból származó borainak profilanalízise 


\section{Második szüreti időpont}

A második szüreti időpontra az volt a jellemző, hogy a minőségi különbségek kissé elmosódtak, de még így is kiérezhetőek maradtak a két bor között. A savérzet és teltségérzet, testesség voltak azok a tulajdonságok, amelyekkel a kezelést kapott szőlőből készült bor kiemelkedett (58. ábra).

58. ábra - A 2012-es évjárat második szüreti időpontból származó borainak profilanalízise 


\section{Harmadik szüreti időpont}

A lombtrágya által okozott pozitív hatások a harmadik szüreti időpontra voltak a legjobban érzékelhetőek. A bírálók, a hat kóstolt bor közül egyértelmüen a harmadik szüretelésü, kezelt bort nevezték meg legjobbként. A kezelt bor, a lombtrágyás kezelésben nem részesült szőlőből készült párjától, a harmadik időpontban is sokkal jobbnak bizonyult. Szembetűnő volt a tanninok krémessége, lágysága, a bor testessége, amit a magasabb sósav és zselatin indexek egyaránt mutatnak (50. és 51. ábra). A fajtára jellemző illatok, ízek jobban domináltak (59. ábra).

59. ábra - A 2012-es évjárat harmadik szüreti időpontból származó borainak profilanalízise 


\subsubsection{A 2013-as évjárat}

\section{Első szüreti időpont}

A borok profilja ebben az évben jóval elmarad a 2012-es évjáratban tapasztalt, „teltebb” formáktól. Ez a jelenség, a kedvezőtlenebb évjárat borminőséget negatívan befolyásoló hatásaiból adódik. Az lombtrágya hatása azonban a 2013. év első szüreti időpontjában is szembetünő. Használatával a savérzet finomabbá, a tanninok minősége jobbá vált. Az éretlen zöld ízérzet mérséklödött, gyümölcsösebb, füszeresebb volt a kezelt bor (60. ábra).

60. ábra - A 2013-as évjárat első szüreti időpontból származó borainak profilanalízise 


\section{Második szüreti időpont}

A lombtrágya hatása, akárcsak 2012-ben, úgy 2013-ban is elhalványult a második szüreti időpontra. A két bor bírálata éppen ezért nehezebbnek bizonyult, mint az előző szüretből származóké, de még így is a kezelést kapott alapanyagból készített bort találták a bírálók jobbnak (61. ábra).

61. ábra - A 2013-as évjárat második szüreti időpontból származó borainak profilanalízise 


\section{Harmadik szüreti időpont}

A lombtrágya befolyása a harmadik szüreti időpontra visszafogottabban jelentkezett, mint 2012-ben, de a különbség kiérezhető maradt a borok között (62. ábra). A bírálók ebben a szüreti időpontban is a kezelt bort találták a jobbnak. Kiemelték, hogy füszeresebb illat- és ízjegyekkel, finomabb tanninokkal, illetve hosszabb lecsengéssel rendelkezett. Ez összefüggést mutat a szignifikánsan magasabb zselatin és sósav index értékeivel (50. és 51. ábra).

A kedvezőtlen évjárathatás miatt ugyanakkor mind a kontroll, mind a kezelt borok minősége jócskán elmaradt az előző évben tapasztalttól.

A 2013-as évjárat borairól összességében megállapítható, hogy a kívántnál több savat tartalmaztak és beltartalmi értékeikben elmaradtak a 2012-es évjárat borsorától. Az elvártnál vékonyabbak voltak és jellemző volt rájuk a fenolos érettség hiányából fakadó húzós ízérzet.

62. ábra - A 2013-as évjárat második szüreti időpontból származó borainak profilanalízise 


\subsection{1. Új tudományos eredmények}

Több szempontból is bebizonyosodott, hogy a Syrah szőlőfajtának hazánk klímaviszonyai között nagyon jó termőhelyre és évjáratra van szüksége ahhoz, hogy kiemelkedő bort adjon. Az érési időszak időjárására különösen érzékeny. A 2013 őszén bekövetkezett lehülés hatására a katechin, az összes polifenoltartalom és az antocianin értékek, valamint a zselatin és sósav $(\mathrm{HCl})$ indexek is sokkal alacsonyabban alakultak, mint az azt megelőző évben. Összességében véve a szőlö szignifikánsan alacsonyabb fenolos érettséget ért el 2013-ban, mint 2012-ben.

A Syrah szőlőbogyó fizikai paramétereinek évjáratfüggő, érés során bekövetkező változásainak feltérképezése hűvös klímaviszonyok között. A zsendülés utáni időszakban a héj vastagsága $\left(\mathrm{Sp}_{\mathrm{sk}}\right)$ és a mag keménysége $\left(\mathrm{F}_{\mathrm{s}}\right)$ a különböző szüreti időpontok során már nem változott. A bogyó egésze $(\mathrm{BH})$ illetve a héj $\left(\mathrm{F}_{\mathrm{sk}}\right)$ ezzel szemben az érés előrehaladtával egyre puhábbá vált.

A fenolos érettség elősegítése elsősorban az antocianinok termelődésének előmozdításában nyilvánult meg. A színanyagok koncentrációja, a LalVigne ${ }^{\circledR}$ Mature által kezelt szőlőben és a belőle készült borokban egyaránt magasabb volt. Ez a megállapítás az összes mintavételi időpontra és borra igaz. A lombtrágya ezen túlmenően nem csak az antocianinok mennyiségére, hanem kivonhatóságára is számos esetben gyakorolt pozitív hatást.

A lombtrágya alkalmazásával jelentős héjvastagodást $\left(\mathrm{Sp}_{\mathrm{sk}}\right)$ értem el, amely minden vizsgálati időpontban igazolható volt.

A lomtrágya hatására mindkét évjáratban szignifikáns különbség mutatkozott a kontroll és a kezelt borok között a titrálható savtartalomban és a rezveratrol koncentrációjában az érés korai fázisában (első szüreti időpont). A kezelt borok kevesebb savat, valamint több rezveratrolt tartalmaztak.

A kontroll és a lombtrágyával kezelt szőlőből készült borok között a bírálók, az érzékszervi bírálat során minden esetben különbséget tudtak tenni, bár a pontszámok közötti különbség statisztikailag nem volt szignifikáns. A bírálók minden esetben a kezelésben részesült szőlöből készült borokat részesítették előnyben. 


\section{KÖVETKEZTETÉSEK ÉS JAVASLATOK}

A LalVigne ${ }^{\circledR}$ Mature kereskedelmi forgalomba hozatalát, az alkalmazásából eredő egyértelmü pozitív hatásokra való tekintettel javaslom. A lombtrágya használatával elérhető minőségjavulás a szőlőben és a belőle készült borokban egyaránt tetten érhető, amit az analitikai vizsgálatok és az érzékszervi bírálatok is tükröznek. A kísérletem során kapott eredményeket és az érés során bekövetkezett előnyös változásokat két, szintén Syrah fajtán beállított külföldi kísérlet is alátámasztja (DUO et al. 2014; LissARRAGUE et al. 2014). A lombtrágyával kapcsolatos megállapítások ezekben az esetekben is hasonlóak voltak. A kezelt tökék több antocianint és az érés kezdeti szakaszában, több rezveratrolt termeltek.

A kísérlet szempontjából szerencsés tényként értékelhető, hogy a lombtrágya teljesítményét egy nagyon jó és egy kedvezőtlenebb évjáratban is próbára lehetett tenni. Az adatok kiértékelése során világossá vált, hogy a lombtrágya képes a fenolos érés bizonyos fokú elősegítésére. Ebből a jelenségből azokban az években lehet profitálni, amelyekben a nagy hőség hatására a cukorképződés hajlamos olyannyira felgyorsulni, hogy a túlzott alkoholtartalmú borok veszélye valós problémává válik anélkül, hogy a szőlő elérte volna a fenolos érettséget. Az ilyen borok sok esetben mutatnak diszharmóniát és olyan nem megfelelő érettségre utaló ízeket, amelyet a fogyasztók nem kedvelnek. A lombtrágya képes volt javítani az egyensúlyt a technológiai (mustfok szerinti) és a fenolos (tannin) érettség között. Használatával a szüret akár előrébb is hozható és kisebb cukortartalommal, valamint magasabb tanninérettséggel kezdhető meg. Ezzel szemben a kedvezőtlenebb években, mint amilyen 2013 is volt, az érés nagyon lelassul, a szürettel sok esetben ki kell várni. Az ősszel gyakorta rosszabbra forduló időjárás és az erős fertőzési nyomás miatt azonban ezt nem mindig lehet megtenni. Ezekben az esetekben is hasznosnak mutatkozott a LalVigne ${ }^{\circledR}$ Mature lombtrágya használata. A kontroll szőlőhöz képest magasabb beltartalmi értékű alapanyagot sikerült szüretelni. A kezelés következtében kialakult vastagabb héj nemcsak magasabb színanyagtartalmával hívhatja fel magára a figyelmet. A vastagabb héjnak komoly szerepe lehet a növényvédelmi kezelések hatásfokának növelésében, a kórokozó gombák általi fertőzési veszély csökkentésével. A kijutatott permetszerek mennyisége, ezáltal a környezet terhelése csökkenthető. Az kisebb alkalmazott szerdózisnak pénzügyi vonzata is van, hiszen gazdaságosabbá teszi a müvelést.

A lombtrágya hatásmechanizmusa a növény-patogén kölcsönhatáson alapul (LANGCAKE ÉS PryCe 1976; HAhN 1996; GARCIA-BRUGGER et al. 2006; SANTAMARIA et al. 2011). A szőlő 
az élesztőtartalmú lombtrágyát idegen anyagként, „betolakodóként” érzékeli, ami aktiválja a növényvilágban jellemző védekező mechanizmusokat. A másodlagos anyagcseretermékek termelödéséért felelős anyagcsere utak (jazmonsav/etilén út, szalicilsav út és sikiminsav út) során rendkívül sok fenolos vegyület és aromaanyag termelődik. A kijuttatott lombtrágya tehát elsősorban ezekre az anyagcsere utakra van hatással azáltal, hogy a védekező anyagok (ide tartoznak a fenolos vegyületek is) bioszintézise során képződő vegyületek termelődést fokozza (ZHAO et al. 2005). Ezzel magyarázható a fokozott antocianin termelődés, bizonyos esetekben a magasabb rezveratrol tartalom, valamint a héjvastagodás is.

A kezelés hatására kialakult különbségek némely esetben (pl.: a második szüreti időpontból származó borok érzékszervi bírálata) csekélynek tünhetnek. Meg kell említeni azonban azt a fontos tényt, hogy egy olyan terroir szemléletü és nagy értékü presztízsborokat termelő pincészetnél, mint a Gróf Buttler, a vevők az apróbb minőségbeli növekedést is komolyan értékelik. Minden, a minőség növelésére irányuló törekvés számos haszonnal kecsegtet.

A Syrah-ról újra bebizonyosodott az, amit sok esetben már sejteni lehetett. Nagyon érzékenyen reagál az évjárathatásra és a hazánk klímaviszonyaiból adódó szeszélyes időjárásra, amit a jövőben a klímaváltozás még jobban fokozhat. Egy olyan évjáratban, mint amilyen a 2011-es, vagy a 2012-es is volt, igazán jól teljesített, a számára kedvező időjárási (sok napsütés, hosszú, meleg tenyészidő) körülmények megléte miatt. 2013-ban azonban, a jóval hűvösebb és esősebb ősz miatt képtelen volt a kellő érettséget elérni. Kijelenthető tehát, hogy hazánkban igen kivételes évjárat szükséges ahhoz, hogy kiemelkedő borok születhessenek a fajtából. Nem elhanyagolandó tény továbbá, a megfelelő termőhely kiválasztása sem. Telepítése, csakis a legkiválóbb dülőkbe javasolható, olyan helyekre, amelyek déli kitettségüek, így a tenyészidő egésze alatt a lehető legtöbb napfényt és hőt kapják. A fagyveszélyes zugok elkerülésére is nagy hangsúlyt kell fektetni. A Nagy-Eged-hegy ezeknek a követelményeknek maradéktalanul megfelel.

A Syrah fajtaborként történő forgalomba hozatala tehát, csakis az általa megkövetelt összes termesztési feltétel együttállása esetén javasolható. A gyengébb évjáratokban és nem megfelelő termőhelyen termelt Syrah borok elsősorban vörös házasításokba valók, ahol az általában jellemző magas színanyagtartalom mély színt kölcsönözhet a cuvée-nek. Fűszeressége révén pedig gazdagíthatja a házasított bor aromaprofilját. Megfelelő évjáratból származó borának használata, az előbb részletezett tulajdonságaiból kifolyólag, az Egri Bikavérben is előnyös lehet. 
A bemutatott lombtrágyázási technológia még hatékonyabbá tétele érdekében, a jövőben újabb kísérletek beállítása szükséges, egyéb fajtákon, termőhelyeken, eltérő klimatikus és időjárási viszonyok között. A fenolos vegyületek még alaposabb, nagymüszeres vizsgálata szintén javasolható. 


\section{7. ÖSSZEFOGLALÁS}

A kísérlet során a Lallemand cég által kifejlesztett, LalVigne ${ }^{\circledR}$ Mature nevü lombtrágyájának hatását vizsgáltam a szőlő fenolos érettségének és a bor fenolos vegyületeinek összetételére, valamint mennyiségük alakulására nézve. A lombtrágyát Syrah fajtán teszteltem két évjáratban $(2012,2013)$ a hüvös klímával rendelkező Egri Borvidéken. A kísérleti borokat mindkét évjáratban három szüreti időpontban készítettem el. A szőlő és a bor rutinanalitikáján túl a borok rezveratroltartalmát is meghatároztam. A szőlő érése során a bogyó színanyagainak kivonhatóságát és fizikai tulajdonságainak változását is nyomon követtem. A kezelt szőlők bogyóhéja minden mintavételi időpontban és mindkét évjáratban vastagabb volt. A lombtrágyával kezelt szőlőbogyók és borok antocinain koncentrációja egyaránt magasabb volt, mint a kontroll. A kísérletek azt mutatják, hogy a fenolos érés, a lombtrágya használatával előnyösen befolyásolható. Ezáltal harmonikusabb, gazdagabb borok készíthetőek, a túlérés veszélye nélkül. A kapott eredmények alapján a lombtrágya használata hasznosnak bizonyult egymástól eltérő évjáratokban is. A hidegebb és kedvezőetlenebb évjáratban az érési folyamat elősegítésével nagyobb borászati potenciállal rendelkező borok születtek. A szőlő fenolos érettsége (különösösképpen az antocianinok mennyisége és kivonhatósága) a lombtrágyás kezelés hatására nagymértékben javult. 


\section{SUMMARY}

We examined the impacts of yeast derivatives applications (LalVigne ${ }^{\circledR}$ Mature, Lallemand Inc.) on Syrah grape phenolic maturity as well as wine phenolic composition and concentration. This foliar spray was tested on Syrah vines in two vintages $(2012,2013)$ in a cool climate wine region (Eger, Hungary). Experimental wines were made at three separate harvest times in each vintage. Standard analytical parameters for grapes and wines as well as resveratrol were evaluated. Changes in anthocyanin extractability and texture characteristics of the grape berries were followed during ripening. Grapes from treated vines had thicker skins than controls at all sampling dates in both vintages. Our experiment showed that phenolic ripening can be enhanced using the foliar spray. Therefore more balanced wines with more complexity could be produced without the danger of overripening. The results show that the application of the foliar spray is useful in different vintages. Preliminary evidence was also obtained to suggest that LalVigne ${ }^{\circledR}$ Mature may also help in cooler and less optimal vintages by enhancing the ripening process leading to wines with greater oenological potential. The phenolic maturity (especially anthocyanin concentration and its extractability) of the foliar spray treated grapes was greatly improved. 


\section{IRODALOMJEGYZÉK}

Alcalde-Eon, C., Escribano-Bailón, M.T., Santos-Buelga, C. És Rivas-Gonzalo, J.C. (2006) Changes in the detailed pigment composition of red wine during maturity and ageing: A comprehensive study. Anal. Chim. Acta 563, 238-254. http://dx.doi.org/10.1016/j.aca.2005.11.028

Álvarez, I., AleiXANDRe, J.L., GARCÍA, M.J. ÉS LiZAma, V. (2006) Impact of prefermentative maceration on the phenolic and volatile compounds in Monastrell red wines. Anal. Chim. Acta 563, 109-115. http://dx.doi.org/10.1016/j.aca.2005.10.068

AMERINE, M.A. És Ough, C.S. (1980) Methods for analysis of musts and wines. Wiley, New York.

Avila, F., Mora, M. És Fredes, C. (2014) A method to estimate Grape Phenolic Maturity based on seed images. Comput. Electron. Agric. 101, 76-83. http://dx.doi.org/10.1016/j.compag.2013.12.006

Baldi, A., Romani, A., Mulinacci, N., Vincieri, F.F. És Casetta, B. (1995) HPLC/MS application to anthocyanins of Vitis vinifera L. J. Agric. Food Chem. 43, 2104-2109. http://dx.doi.org/10.1021/jf00056a027

BÁNyAi, G.B., ERCSEY, D., MÉSzÁROS, G. ÉS ToMPA, I. (2012) Nagy magyar boratlasz. Mountner \& Pitman, Budapest.

BAte-Smith, E.C. (1954) Leuco-anthocyanins. 1. Detection and identification of anthocyanidins formed from leuco-anthocyanins in plant tissues. Biochem. J. 58, 122-125.

Bautista-Ortín, A.B., Martínez-Cutillas, A., Ros-García, J.M., LóPez-RocA, J.M. És GÓMEZ-PlAZA, E. (2005) Improving colour extraction and stability in red wines: the use of maceration enzymes and enological tannins. Int. J. Food Sci. Tech. 40, 867-878. http://dx.doi.org/10.1111/j.1365-2621.2005.01014.x

BAVARESCO, L. (2003) Role of viticultural factors on stilbene concentrations of grapes and wine. Drugs Exp. Clin. Res. 29, 181-187. http://europepmc.org/abstract/MED/15134373

Bavaresco, L., Pezzutto, S., Gatti, M. ÉS Mattivi, F. (2007) Role of the variety and some environmental factors on grape stilbenes. Vitis 46, 57-61.

BergQvist, J., Dokoozlian, N.K. És EBISUdA, N. (2001) Sunlight exposure and temperature effects on berry growth and composition of Cabernet Sauvignon and Grenache in the Central San Joaquin Valley of California. Am. J. Enol. Vitic. 52, 1-7. http://www.ajevonline.org/cgi/content/abstract/52/1/1

Bogs, J., Downey, M.O., Harvey, J.S., Ashton, A.R., TAnner, G.J. És Robinson, S.P. (2005) Proanthocyanidin synthesis and expression of genes encoding leucoanthocyanidin reductase and anthocyanidin reductase in developing grape berries and grapevine leaves. Plant Physiol. 139, 652-663. http://dx.doi.org/10.1104/pp.105.064238

Boulton, R. (2001) The copigmentation of anthocyanins and its role in the color of red wine: A $\begin{array}{llllll}\text { critical } & \text { review. } & \text { Emol. }\end{array}$ http://www.ajevonline.org/content/52/2/67.abstract

Bowers, J.E., Siret, R., Meredith, C.P., This, P. ÉS BoursiQuot, J.-M. (2000) A single pair of parents proposed for a group of grapevine varieties in Northeast France. Acta Hortic. $528,129-132$.

Bruwer, J., SAliBA, A. ÉS Miller, B. (2011) Consumer behaviour and sensory preference differences: implications for wine product marketing. J. Consum. Mark. 28, 5-18. http://dx.doi.org/10.1108/07363761111101903

Bucchetti, B., Matthews, M.A., Falginella, L., Peterlunger, E. És Castellarin, S.D. (2011) Effect of water deficit on Merlot grape tannins and anthocyanins across four seasons. Sci. Hortic. 128, 297-305. http://dx.doi.org/10.1016/j.scienta.2011.02.003

Busse-Valverde, N., Gomez-Plaza, E., Lopez-Roca, J.M., Gil-Munoz, R., FernandezFERNANDEZ, J.I. ÉS BAUTISTA-ORTIN, A.B. (2010) Effect of different enological practices 
on skin and seed proanthocyanidins in three varietal wines. J. Agric. Food Chem. 58, 11333-11339. http://dx.doi.org/10.1021/jf102265c

CAdot, Y., MiÑana-Castelló, M.T. És Chevalier, M. (2006) Anatomical, histological, and histochemical changes in grape seeds from Vitis vinifera L. cv Cabernet franc during fruit development. J. Agric. Food Chem. 54, 9206-9215. http://dx.doi.org/10.1021/jf061326f

Cagnasso, E., Rolle, L., Caudana, A. És Gerbi, V. (2008) Relationship between grape phenolic maturity and red wine phenolic composition. Ital. J. Food Sci. 20, 365-380.

Cagnasso, E., Torchio, F., Gerbi, V., Segade, S.R., Giacosa, S. És Rolle, L. (2011) Evolution of the phenolic content and extractability indices during ripening of Nebbiolo grapes from the Piedmont growing areas over six consecutive years. S. Afr. J. Enol. Vitic. 32, 229-241.

CAnals, R., Llaudy, M.C., VAlls, J., CANAls, J.M. ÉS ZAmora, F. (2005) Influence of ethanol concentration on the extraction of color and phenolic compounds from the skin and seeds of tempranillo grapes at different stages of ripening. J. Agric. Food Chem. 53, 40194025. http://dx.doi.org/10.1021/jf047872v

Casassa, L.F., Beaver, C.W., Mireles, M., Larsen, R.C., Hopfer, H., Heymann, H. és HARBERTSON, J.F. (2013) Influence of fruit maturity, maceration length, and ethanol amount on chemical and sensory properties of Merlot wines. Am. J. Enol. Vitic. 64, 437449. http://dx.doi.org/10.5344/ajev.2013.13059

Castellarin, S.D., MAtThews, M.A., GasPero, G. És GAmbetta, G.A. (2007a) Water deficits accelerate ripening and induce changes in gene expression regulating flavonoid biosynthesis in grape berries. Planta 227, 101-112. http://dx.doi.org/10.1007/s00425$\underline{007-0598-8}$

Castellarin, S.D., Pfeiffer, A., Sivilotti, P., Degan, M., Peterlunger, E. És Di Gaspero, G. (2007b) Transcriptional regulation of anthocyanin biosynthesis in ripening fruits of grapevine under seasonal water deficit. Plant Cell Environ. 30, 1381-1399. http://dx.doi.org/10.1111/j.1365-3040.2007.01716.x

Castillo-Muñoz, N., FernándeZ-GonzÁlez, M., GómeZ-Alonso, S., García-Romero, E. ÉS HERMosíN-GUTIÉRREZ, I. (2009) Red-color related phenolic composition of Garnacha Tintorera (Vitis vinifera L.) grapes and red wines. J. Agric. Food Chem. 57, 7883-7891. http://dx.doi.org/10.1021/if9002736

Celotti, E., Della Vedova, T., Ferrarini, R. És Martinand, S. (2007) The use of reflectance for monitoring phenolic maturity curves in red grapes. Ital. J. Food Sci. 19, 91-100.

Cerovic, Z.G., Moise, N., Agati, G., Latouche, G., Ben Ghozlen, N. És Meyer, S. (2008) New portable optical sensors for the assessment of winegrape phenolic maturity based on berry fluorescence. J. Food Comp. Anal. 21, 650-654. http://dx.doi.org/10.1016/j.jfca.2008.03.012

CERPA-CALDERON, F.K. ÉS KENNEDY, J.A. (2008) Berry integrity and extraction of skin and seed proanthocyanidins during red wine fermentation. J. Agric. Food Chem. 56, 9006-9014. http://dx.doi.org/10.1021/jf801384v

Chalmers, Y.M., Downey, M.O., Krstic, M.P., LoveYs, B.R. És Dry, P.R. (2010) Influence of sustained deficit irrigation on colour parameters of Cabernet Sauvignon and Shiraz microscale wine fermentations. Aust. J. Grape Wine Res. 16, 301-313. http://dx.doi.org/10.1111/j.1755-0238.2010.00093.x

Cheynier, V., Prieur, C., Guyot, S., Rigaud, J. És Moutounet, M. (1997) The structures of tannins in grapes and wines and their interactions with proteins. In Wine. pp. 81-93. American Chemical Society. http://dx.doi.org/10.1021/bk-1997-0661.ch008

Cheynier, V., Dueñas-Paton, M., Salas, E., Maury, C., Souquet, J.-M., Sarni-Manchado, P. ÉS FulCRAND, H. (2006) Structure and properties of wine pigments and tannins. Am. J. Enol. Vitic. 57, 298-305. http://www.ajevonline.org/content/57/3/298.abstract 
Chorti, E., Guidoni, S., Ferrandino, A. És Novello, V. (2010) Effect of different cluster sunlight exposure levels on ripening and anthocyanin accumulation in Nebbiolo grapes. Am. J. Enol. Vitic. 61, 23-30. http://www.ajevonline.org/content/61/1/23.abstract

Cortell, J.M., Halbleib, M., Gallagher, A.V., Righetti, T.L. És Kennedy, J.A. (2005) Influence of vine vigor on grape (Vitis vinifera L. cv. Pinot noir) and wine proanthocyanidins. J. Agric. Food Chem. 53, 5798-5808. http://dx.doi.org/10.1021/jf0504770

Cortell, J.M., Halbleib, M., Gallagher, A.V., Righetti, T.L. És Kennedy, J.A. (2007a) Influence of vine vigor on grape (Vitis vinifera L. cv. Pinot noir) anthocyanins. 2. Anthocyanins and pigmented polymers in wine. J. Agric. Food Chem. 55, 6585-6595. http://dx.doi.org/10.1024/jf070196n

Cortell, J.M., Halbleib, M., Gallagher, A.V., Righetti, T.L. És Kennedy, J.A. (2007b) Influence of vine vigor on grape (Vitis vinifera L. cv. Pinot noir) anthocyanins. 1. Anthocyanin concentration and composition in fruit. J. Agric. Food Chem. 55, 65756584. http://dx.doi.org/10.1021/jf070195v

CORTEll, J.M., SiverTSEN, H.K., KenNeDy, J.A. ÉS HEYMAnN, H. (2008) Influence of vine vigor on Pinot noir fruit composition, wine chemical analysis, and wine sensory attributes. $\mathrm{Am}$. J. Enol. Vitic. 59, 1-10. http://www.ajevonline.org/content/59/1/1.abstract

DÁvalos, A. ÉS LASUnCiÓN, M.A. (2009) Health-promoting effects of wine phenolics. In Wine Chemistry and Biochemistry. Moreno-ArriBAs, M.V. ÉS POLO, M.C. (eds.), pp. 571591. Springer New York. http://dx.doi.org/10.1007/978-0-387-74118-5_25

DE FreitAs, V. ÉS GlORIES, Y. (1999) Concentration and compositional changes of procyanidins in grape seeds and skin of white Vitis vinifera varieties. J. Sci. Food Agric. 79, 16011606. $\quad$ http://dx.doi.org/10.1002/(SICI)1097-0010(199909)79:12<1601::AIDJSFA407>3.0.CO;2-1

DE FReitAS, V. ÉS MATEUS, N. (2011) Formation of pyranoanthocyanins in red wines: a new and diverse class of anthocyanin derivatives. Anal. Bioanal. Chem. 401, 1463-1473. http://dx.doi.org/10.1007/s00216-010-4479-9

del Llaudy, M.C., Canals, R., GonzÁlez-Manzano, S., Canals, J.M., Santos-Buelga, C. ÉS ZAMORA, F. (2006) Influence of micro-oxygenation treatment before oak aging on phenolic compounds composition, astringency, and color of red wine. J. Agric. Food Chem. 54, 4246-4252. http://dx.doi.org/10.1021/jf052842t

DEl Llaudy, M.C., CANAls, R., CANAls, J.M. ÉS ZAMORA, F. (2008) Influence of ripening stage and maceration length on the contribution of grape skins, seeds and stems to phenolic composition and astringency in wine-simulated macerations. Eur. Food Res. Technol. 226, 337-344. http://dx.doi.org/10.1007/s00217-006-0542-3

Delgado, R., Martín, P., Del Álamo, M. És GonzÁlez, M.-R. (2004) Changes in the phenolic composition of grape berries during ripening in relation to vineyard nitrogen and potassium fertilisation rates. J. Sci. Food Agric. 84, 623-630. http://dx.doi.org/10.1002/jsfa.1685

Deloire, A., Vaudour, E., CARey, V., Bonnardot, V. ÉS van Leeuwen, C. (2005) Grapevine responses to terroir: A global approach. J. Int. Sci. Vigne Vin. 39, 149-162.

Diago, M.P., Ayestarán, B., Guadalupe, Z., Poni, S. ÉS TARdÁguila, J. (2012) Impact of prebloom and fruit-set basal leaf removal on the flavonol and anthocyanin composition of Tempranillo grapes. Am. J. Enol. Vitic. http://dx.doi.org/10.5344/ajev.2012.11116

Dos Santos, T.P., Lopes, C.M., Rodrigues, M.L., De Souza, C.R., Ricardo-Da-Silva, J.M., Maroco, J.P., PereirA, J.S. ÉS CHAVES, M.M. (2005) Effects of partial root-zone drying irrigation on cluster microclimate and fruit composition of field-grown Castelão grapevines. Vitis 44, 117-125.

Downey, M.O., HaRVey, J.S. ÉS Robinson, S.P. (2003) Analysis of tannins in seeds and skins of Shiraz grapes throughout berry development. Aust. J. Grape Wine Res. 9, 15-27. http://dx.doi.org/10.1111/j.1755-0238.2003.tb00228.x 
Downey, M.O., HARVEY, J.S. ÉS Robinson, S.P. (2004) The effect of bunch shading on berry development and flavonoid accumulation in Shiraz grapes. Aust. J. Grape Wine Res. 10, 55-73. http://dx.doi.org/10.1111/j.1755-0238.2004.tb00008.x

Ducasse, M.-A., Canal-Llauberes, R.-M., De Lumley, M., Williams, P., Souquet, J.-M., FulCRAND, H., Doco, T. ÉS CHEYNIER, V. (2010) Effect of macerating enzyme treatment on the polyphenol and polysaccharide composition of red wines. Food Chem. 118, 369376. http://dx.doi.org/10.1016/j.foodchem.2009.04.130

Duo, A., Souquet, J.M., SAmson, A., Caille, S., Silvano, A., SuÁrez, C. És OJedA, H. (2014) Elicitors and water stress. Effect on Syrah grapes \& wine quality cultivated in Gruissan, France. Published In Proceedings of the $37^{\text {th }}$ World Congress of Vine and Wine \& $12^{\text {th }}$ General Assembly of the OIV Book of Abstracts. JEAN-MARIE, A. (ed.), pp. 466.

FERNÁNDEZ-LÓPEZ, J.A., HidAlgo, V., Almela, L. ÉS RoCA, J.M.L. (1992) Quantitative changes in anthocyanin pigments of Vitis vinifera cv Monastrell during maturation. J. Sci. Food Agric. 58, 153-155. http://dx.doi.org/10.1002/jsfa.2740580127

Ferrer-Gallego, R., García-Marino, M., Hernández-Hierro, J.M., Rivas-Gonzalo, J.C. ÉS ESCRIBANO-BAILÓN, M.T. (2010) Statistical correlation between flavanolic composition, colour and sensorial parameters in grape seed during ripening. Anal. Chim. Acta 660, 22-28. http://dx.doi.org/10.1016/j.aca.2009.09.039

Flanzy, M., AuberT, S. ÉS MARINOS, M. (1969) New technique for determination of leucoanthocyanic tannins. Appl. Ann. Technol. Agric. 18, 327-328.

Fournand, D., Vicens, A., Sidhoum, L., Souquet, J.M., Moutounet, M. És Cheynier, V. (2006) Accumulation and extractability of grape skin tannins and anthocyanins at different advanced physiological stages. J. Agric. Food Chem. 54, 7331-7338. http://dx.doi.org/10.1021/jf061467h

FrickNé ÁdÁM, A., KÁLlAY, M. ÉS LESKÓ, A. (2013) Vörösborok rezveratroltartalma és teljes antioxidáns kapacitása. Borászati Füzetek 24, 1-4.

Gambuti, A., Strollo, D., Ugliano, M., Lecce, L. És Moio, L. (2004) Trans-resveratrol, quercetin, $(+)$-catechin, and (-)-epicatechin content in South Italian monovarietal wines: Relationship with maceration time and marc pressing during winemaking. J. Agric. Food Chem. 52, 5747-5751. http://dx.doi.org/10.1021/jf0354895

Garcia-Brugger, A., Lamotte, O., Vandelle, E., Bourque, S., LecourieuX, D., Poinssot, B., Wendehenne, D. És Pugin, A. (2006) Early signaling events induced by elicitors of plant defenses. Mol. Plant Microbe Interact. 19, 711-24. http://dx.doi.org/10.1094/mpmi19-0711

Gatti, M., Bernizzoni, F., Civardi, S. ÉS Poni, S. (2012) Effects of cluster thinning and preflowering leaf removal on growth and grape composition in cv. Sangiovese. Am. J. Enol. Vitic. 63, 325-332. http://dx.doi.org/10.5344/ajev.2012.11118

GAwEL, R. (1998) Red wine astringency: a review. Aust. J. Grape Wine Res. 4, 74-95. http://dx.doi.org/10.1111/j.1755-0238.1998.tb00137.x

Gil-Munoz, R., Moreno-PereZ, A., Vila-LoPeZ, R., FernandeZ-FernandeZ, J.I., MartinezCutillas, A. ÉS GOMEZ-PlazA, E. (2009) Influence of low temperature prefermentative techniques on chromatic and phenolic characteristics of Syrah and Cabernet Sauvignon wines. Eur. Food Res. Technol. 228, 777-788. http://dx.doi.org/10.1007/s00217-0080989-5

GLORIES, Y. (1984) La couleur des vins rouges II. Mesure, origine et interpretation. Connaissance Vigne Vin 18, 253-271.

GloRies, Y. ÉS AUGUSTIN, M. (1993) Maturité phénolique du raisin, conséquences technologiques: Applications aux millésimes 1991 et 1992. Published In Proceedings of the Actes du Colloque Journée Technique du CIVB. pp. 56-61.

Gómez-Míguez, M. ÉS HEREDIA, F.J. (2004) Effect of the maceration technique on the relationships between anthocyanin composition and objective color of Syrah wines. $J$. Agric. Food Chem. 52, 5117-5123. http://dx.doi.org/10.1021/jf049570z 
Gómez-Míguez, M., GonzÁlez-Miret, M.L. És Heredia, F.J. (2007) Evolution of colour and anthocyanin composition of Syrah wines elaborated with pre-fermentative cold maceration. J. Food Eng. 79, 271-278. http://dx.doi.org/10.1016/j.jfoodeng.2006.01.054

GonzÁlez-Manzano, S., Rivas-Gonzalo, J.C. És SANTOS-Buelga, C. (2004) Extraction of flavan-3-ols from grape seed and skin into wine using simulated maceration. Anal. Chim. Acta 513, 283-289. http://dx.doi.org/10.1016/j.aca.2003.10.019

GonzÁlez-Neves, G., Barreiro, L., Gil, G., Franco, J., Ferrer, M., Moutounet, M. És CARbonneau, A. (2004a) Anthocyanic composition of Tannat grapes from the south region of Uruguay. Anal. Chim. Acta 513, 197-202. http://dx.doi.org/10.1016/j.aca.2003.11.078

GonzÁlez-Neves, G., Charamelo, D., Balado, J., Barreiro, L., Bochicchio, R., Gatto, G., Gil, G., Tessore, A., Carbonneau, A. És Moutounet, M. (2004b) Phenolic potential of Tannat, Cabernet Sauvignon and Merlot grapes and their correspondence with wine composition. Anal. Chim. Acta 513, 191-196. http://dx.doi.org/10.1016/j.aca.2003.11.042

GonzÁlez-Neves, G., Gil, G., BArreiro, L. És FAVre, G. (2010a) Pigment profile of red wines cv. Tannat made with alternative winemaking techniques. J. Food Comp. Anal. 23, 447454. http://dx.doi.org/10.1016/j.jfca.2009.08.021

González-Neves, G., Gil, G., Ferrer, M., Charamelo, D., Balado, J., Bochicchio, R., Gatto, G. ÉS Tessore, A. (2010b) Prediction of the colour and polyphenolic composition of the young red wines from the phenolic potential of the grapes. Int. J. Food Sci. Tech. 45, 1843-1851. http://dx.doi.org/10.1111/j.1365-2621.2010.02343.x

GonzÁlez-Neves, G., Gil, G., Favre, G., Baldi, C., Hernández, N. És Traverso, S. (2013) Influence of winemaking procedure and grape variety colour and composition of young red wines. S. Afr. J. Enol. Vitic. 34, 138-146.

Gordillo, B., LÓPEZ-INFANTE, M.I., RAMÍREZ-PÉREZ, P., GonZÁlez-Miret, M.L. És HerediA, F.J. (2010) Influence of prefermentative cold maceration on the color and anthocyanic copigmentation of organic Tempranillo wines elaborated in a warm climate. J. Agric. Food Chem. 58, 6797-6803. http://dx.doi.org/10.1021/jf100084x

Guidoni, S., Allara, P. ÉS Schubert, A. (2002) Effect of cluster thinning on berry skin anthocyanin composition of Vitis vinifera cv. Nebbiolo. Am. J. Enol. Vitic. 53, 224-226. http://www.ajevonline.org/content/53/3/224.abstract

Guidoni, S., Ferrandino, A. ÉS Novello, V. (2008) Effects of seasonal and agronomical practices on skin anthocyanin profile of Nebbiolo grapes. Am. J. Enol. Vitic. 59, 22-29. http://www.ajevonline.org/cgi/content/abstract/59/1/22

Hahn, M.G. (1996) Microbial elicitors and their receptors in plants. Annu. Rev. Phytopathol. 34, 387-412. http://dx.doi.org/doi:10.1146/annurev.phyto.34.1.387

Hanlin, R.L., Hrmova, M., Harbertson, J.F. És Downey, M.O. (2010) Review: Condensed tannin and grape cell wall interactions and their impact on tannin extractability into wine. Aust. J. Grape Wine Res. 16, 173-188. http://dx.doi.org/10.1111/j.1755$\underline{0238.2009 .00068 . \mathrm{X}}$

Hannah, L., Roehrdanz, P.R., Ikegami, M., Shepard, A.V., Shaw, M.R., Tabor, G., Zhi, L., MARQuet, P.A. ÉS HiJMAns, R.J. (2013) Climate change, wine, and conservation. Proc. Natl. Acad. Sci. U.S.A. 110, 6907-6912. http://dx.doi.org/10.1073/pnas.1210127110

HARBERTSON, J.F., KENNEDY, J.A. És ADAMS, D.O. (2002) Tannin in skins and seeds of Cabernet Sauvignon, Syrah, and Pinot noir berries during ripening. Am. J. Enol. Vitic. 53, 54-59. http://www.ajevonline.org/content/53/1/54.abstract

Haselgrove, L., Botting, D., van Heeswijck, R., HØJ, P.B., Dry, P.R., Ford, C. És Land, P.G.I. (2000) Canopy microclimate and berry composition: The effect of bunch exposure on the phenolic composition of Vitis vinifera L cv. Shiraz grape berries. Aust. J. Grape Wine Res. 6, 141-149. http://dx.doi.org/10.1111/j.1755-0238.2000.tb00173.x 
Herderich, M.J. ÉS SMITH, P.A. (2005) Analysis of grape and wine tannins: Methods, applications and challenges. Aust. J. Grape Wine Res. 11, 205-214. http://dx.doi.org/10.1111/j.1755-0238.2005.tb00288.x

HERNÁNDEZ-HIERRO, J.M., QUIJADA-MORÍN, N., RiVAS-GONZALO, J.C. ÉS ESCRIBANO-BAILÓN, M.T. (2012) Influence of the physiological stage and the content of soluble solids on the anthocyanin extractability of Vitis vinifera L. cv. Tempranillo grapes. Anal. Chim. Acta 732, 26-32. http://dx.doi.org/10.1016/j.aca.2011.10.056

HernándeZ-Hierro, J.M., QuiJadA-Morín, N., MartíneZ-Lapuente, L., GuadaluPe, Z., Ayestarán, B., Rivas-GonZAlo, J.C. És EscribanO-BAIlón, M.T. (2014) Relationship between skin cell wall composition and anthocyanin extractability of Vitis vinifera L. cv. Tempranillo at different grape ripeness degree. Food Chem. 146, 41-47. http://dx.doi.org/10.1016/j.foodchem.2013.09.037

Huggett, J.M. (2006) Geology and wine: a review. Proc. Geol. Assoc. 117, 239-247. http://dx.doi.org/10.1016/S0016-7878(06)80012-X

JeAndet, P., Bessis, R. ÉS GAUTHERON, B. (1991) The production of resveratrol $(3,5,4$ 'trihydroxystilbene) by grape berries in different developmental stages. Am. J. Enol. Vitic. 42, 41-46. http://www.ajevonline.org/content/42/1/41.abstract

JeAndet, P., Bessis, R., Sbaghi, M. És Meunier, P. (1994) Occurrence of a resveratrol $\beta$-Dglucoside in wine: Preliminary results. Vitis 33, 183-184.

Jeandet, P., Bessis, R., Sbaghi, M., Meunier, P. ÉS Trollat, P. (1995) Resveratrol content of wines of different ages: Relationship with fungal disease pressure in the vineyard. Am. $J$. Enol. Vitic. 46, 1-4. http://www.ajevonline.org/content/46/1/1.abstract

Jones, G.V., White, M.A., COOPER, O.R. ÉS StORCHMAnN, K. (2005) Climate change and global wine quality. Climatic Change 73, 319-343. http://dx.doi.org/10.1007/s10584-005-4704$\underline{2}$

KÁllAY, M. ÉS TÖRÖK, Z. (1997) Determination of resveratrol isomers in Hungarian wines. Kert. Tud. 29, 78-82.

KÁllAY, M. ÉS NYITRAINÉ SÁRDY, D. (2007) Vizsgálatok hazai vörösborok rezveratrol összetételére. Borászati Füzetek 17, 7-11.

KÁllay, M., MÁJer, J. ÉS NYITRAiné SÁRDY, D. (2009) Néhány rezisztens szőlőfajta rezveratroltartalmának vizsgálata. Borászati Füzetek 19, 7-8.

KÁllay, M. ÉS NYITRAINÉ SÁRDY, D. (2009) Analysis of the polyphenolic composition of red wines with paricular respect to the resveratrol concentration. Int. J. Hortic. Sci. 3, 17-22.

KÁllay, M. (2010) Borászati kémia. Mezőgazda Kiadó, Budapest.

KELLER, M. ÉS HRAZDINA, G. (1998) Interaction of nitrogen availability during bloom and light intensity during veraison. II. Effects on anthocyanin and phenolic development during grape ripening. Am. J. Enol. Vitic. 49, 341-349. http://www.ajevonline.org/content/49/3/341.abstract

Kennedy, J.A., Matthews, M.A. ÉS WAterhouse, A.L. (2000a) Changes in grape seed polyphenols during fruit ripening. Phytochemistry 55, 77-85. http://dx.doi.org/10.1016/S0031-9422(00)00196-5

Kennedy, J.A., Troup, G.J., Pilbrow, J.R., Hutton, D.R., Hewitt, D., Hunter, C.R., Ristic, R., ILAND, P.G. ÉS JONES, G.P. (2000b) Development of seed polyphenols in berries from Vitis vinifera L. cv. Shiraz. Aust. J. Grape Wine Res. 6, 244-254. http://dx.doi.org/10.1111/j.1755-0238.2000.tb00185.x

Kennedy, J.A., HAyAsaKa, Y., VidAl, S., WATERS, E.J. ÉS Jones, G.P. (2001) Composition of grape skin proanthocyanidins at different stages of berry development. J. Agric. Food Chem. 49, 5348-5355. http://dx.doi.org/10.1021/jf010758h

Kennedy, J.A., Matthews, M.A. És WAterhouse, A.L. (2002) Effect of maturity and vine water status on grape skin and wine flavonoids. Am. J. Enol. Vitic. 53, 268-274. http://www.ajevonline.org/content/53/4/268.abstract 
Kinsella, J.E., Frankel, E., German, B. És Kanner, J. (1993) Possible mechanisms for the protective role of antioxidants in wine and plant foods. Food Technol. 47, 85-89.

KLIEWER, W.M. (1977) Influence of temperature, solar radiation and nitrogen on coloration and composition of Emperor grapes. Am. J. Enol. Vitic. 28, 96-103. http://www.ajevonline.org/content/28/2/96.abstract

Kontoudakis, N., Esteruelas, M., Fort, F., CANAls, J.M. És ZAMORA, F. (2010) Comparison of methods for estimating phenolic maturity in grapes: Correlation between predicted and obtained parameters. Anal. Chim. Acta 660, 127-133. http://dx.doi.org/10.1016/j.aca.2009.10.067

Kontoudakis, N., Esteruelas, M., Fort, F., Canals, J.M., De Freitas, V. és Zamora, F. (2011a) Influence of the heterogeneity of grape phenolic maturity on wine composition $\begin{array}{llll}\text { and } \text { quality. Food } & \text { Chem. 167-774. }\end{array}$ http://dx.doi.org/10.1016/j.foodchem.2010.06.093

Kontoudakis, N., Esteruelas, M., Fort, F., CAnals, J.M. És ZAmora, F. (2011b) Use of unripe grapes harvested during cluster thinning as a method for reducing alcohol content and $\mathrm{pH}$ of wine. Aust. J. Grape Wine Res. 17, 230-238. http://dx.doi.org/10.1111/j.1755$\underline{0238.2011 .00142 . \mathrm{X}}$

Kontoudakis, N., González, E., Gil, M., Esteruelas, M., Fort, F., Canals, J.M. és ZAMORA, F. (2011c) Influence of wine $\mathrm{pH}$ on changes in color and polyphenol composition induced by micro-oxygenation. J. Agric. Food Chem. 59, 1974-1984. http://dx.doi.org/10.1021/jf103038g

Koshita, Y., Yamane, T., YakushiJ, H., Azuma, A. És Mitani, N. (2011) Regulation of skin color in 'Aki Queen' grapes: Interactive effects of temperature, girdling, and leaf shading treatments on coloration and total soluble solids. Sci. Hortic. 129, 98-101. http://dx.doi.org/10.1016/j.scienta.2011.03.014

LAMB, D.W., WEEDON, M.M. ÉS BRAMLEY, R.G.V. (2004) Using remote sensing to predict grape phenolics and colour at harvest in a Cabernet Sauvignon vineyard: Timing observations against vine phenology and optimising image resolution. Aust. J. Grape Wine Res. 10, 46-54. http://dx.doi.org/10.1111/j.1755-0238.2004.tb00007.x

LANGCAKE, P. ÉS PRYCE, R.J. (1976) The production of resveratrol by Vitis vinifera and other members of the Vitaceae as a response to infection or injury. Physiol. Plant Pathol. 9, 7786. http://dx.doi.org/10.1016/0048-4059(76)90077-1

Le Moigne, M., Maury, C., Bertrand, D. ÉS JourJon, F. (2008) Sensory and instrumental characterisation of Cabernet Franc grapes according to ripening stages and growing location. Food Qual. Pref. 19, 220-231. http://dx.doi.org/10.1016/j.foodqual.2007.03.004

LEE, J. ÉS SKINKIS, P.A. (2013) Oregon 'Pinot noir' grape anthocyanin enhancement by early leaf removal. Food Chem. 139, 893-901. http://dx.doi.org/10.1016/j.foodchem.2013.02.022

Leskó, A., Nyitrai-SÁrdy, D., KÁllay, M. ÉS BAlga, I. (2014) The effect of yeast on the anthocyanin characteristics of fermented model solutions. Acta Aliment. 43, 232-238. http://dx.doi.org/10.1556/AAlim.43.2014.2.6

Letaief, H., Rolle, L. ÉS Gerbi, V. (2008a) Mechanical behavior of winegrapes under compression tests. Am. J. Enol. Vitic. 59, 323-329. http://www.ajevonline.org/cgi/content/abstract/59/3/323

Letaief, H., ROlle, L., ZEPPA, G. ÉS GeRBI, V. (2008b) Assessment of grape skin hardness by a puncture test. J. Sci. Food Agric. 88, 1567-1575. http://dx.doi.org/10.1002/jsfa.3252

Lissarrague, J.R., TÉlleZ, J., GARCÍA, E. És PEIRO, E. (2014) Impact on agronomic parameters in vines and wine quality of foliar treatments with specific fractions of yeast derivatives. Published In Proceedings of the $65^{\text {th }}$ ASEV National Conference \& $39^{\text {th }}$ ASEV Eastern Section Annual Meeting Technical Abstracts. American Society for Enology and Viticulture. pp. 121.

LÖRINCZ, A. ÉS BARÓCSI, Z. (2010) A szőlő metszése és zöldmunkái. Mezőgazda Kiadó, Budapest. 
LÖRINCZ, G., KÁllay, M. ÉS PÁsti, G. (1998) Effect of carbonic maceration on phenolic composition of red wines. Acta Aliment. 27, 341-355.

LUKÁCSY, G. És ZANATHY, G. (2011) A gyürüzés. Agrofórum 22, 96-98.

Mateus, N., Marques, S., Goncalves, A.C., Machado, J.M. És De Freitas, V. (2001) Proanthocyanidin composition of red Vitis vinifera varieties from the Douro valley during ripening: Influence of cultivation altitude. Am. J. Enol. Vitic. 52, 115-121. http://www.ajevonline.org/content/52/2/115.abstract

Mateus, N., MAChAdo, J.M. ÉS DE FReITAS, V. (2002) Development changes of anthocyanins in Vitis vinifera grapes grown in the Douro Valley and concentration in respective wines. $J$. Sci. Food Agric. 82, 1689-1695. http://dx.doi.org/10.1002/jsfa.1237

MAtTHEws, M.A. ÉS ANDERSON, M.M. (1988) Fruit ripening in Vitis vinifera L.: Responses to seasonal water deficits. Am. J. Enol. Vitic. 39, 313-320. http://www.ajevonline.org/content/39/4/313.abstract

MATtivi, F., RENIERO, F. ÉS KorHAMMER, S. (1995) Isolation, characterization, and evolution in red wine vinification of resveratrol monomers. J. Agric. Food Chem. 43, 1820-1823. http://dx.doi.org/10.1021/jf00055a013

Mattivi, F., Vrhovsek, U., Masuero, D. ÉS TrainotTi, D. (2009) Differences in the amount and structure of extractable skin and seed tannins amongst red grape varieties. Aust. J. Grape Wine Res. 15, 27-35. http://dx.doi.org/10.1111/j.1755-0238.2008.00027.x

Maury, C., Madieta, E., Le Moigne, M., Mehinagic, E., Siret, R. És Jourjon, F. (2009) Development of a mechanical texture test to evaluate the ripening process of Cabernet Franc grapes. J. Text. Stud. 40, 511-535. http://dx.doi.org/10.1111/j.17454603.2009.00195.x

MCCARThY, M.G. (1997) The effect of transient water deficit on berry development of cv. Shiraz (Vitis vinifera L.). Aust. J. Grape Wine Res. 3, 2-8. http://dx.doi.org/10.1111/j.1755-0238.1997.tb00128.x

MCCARThy, M.G. (2000) Developmental variation in sensitivity of Vitis vinifera L. (Shiraz) berries to soil water deficit. Aust. J. Grape Wine Res. 6, 136-140. http://dx.doi.org/10.1111/j.1755-0238.2000.tb00172.x

MIRA DE ORDUÑA, R. (2010) Climate change associated effects on grape and wine quality and production. Food Res. Int. 43, 1844-1855. http://dx.doi.org/10.1016/j.foodres.2010.05.001

Monagas, M., BARTOlOMÉ, B. És GÓMEZ-CORdOvÉs, C. (2005) Updated knowledge about the presence of phenolic compounds in wine. Crit. Rev. Food Sci. Nutr. 45, 85-118. http://dx.doi.org/10.1080/10408690490911710

MonagAs, M. És BARTOLOMÉ, B. (2009) Anthocyanins and anthocyanin-derived compounds. In Wine Chemistry and Biochemistry. Moreno-Arribas, M.V. És POlO, M.C. (eds.), pp. 439-462. Springer New York. http://dx.doi.org/10.1007/978-0-387-74118-5_21

Mori, K., SugaYA, S. ÉS GEMMA, H. (2005) Decreased anthocyanin biosynthesis in grape berries grown under elevated night temperature condition. Sci. Hortic. 105, 319-330. http://dx.doi.org/10.1016/j.scienta.2005.01.032

NADAL, M. (2010) Phenolic maturity in red grapes. In Methodologies and Results in Grapevine Research. Delrot, S., Medrano, H., Or, E., Bavaresco, L. És Grando, S. (eds.), pp. 389-409. Springer Netherlands. http://dx.doi.org/10.1007/978-90-481-9283-0 28

NAGEL, C.W. ÉS Wulf, L.W. (1979) Changes in the anthocyanins, flavonoids and hydroxycinnamic acid esters during fermentation and aging of Merlot and Cabernet Sauvignon. Am. J. Enol. Vitic. 30, 111-116. http://www.ajevonline.org/content/30/2/111.abstract

NAGY, R., ZsÓFI, Z., PAPP, I., FÖLDVÁRI, M., KERÉNYI, A. ÉS SZABÓ, S. (2012) Evaluation of the relationship between soil erosion and the mineral composition of the soil: A case study from a cool climate wine region of Hungary. Carpath. J. Earth Environ. Sci. 7, 223-230. 
Ojeda, H., Deloire, A. És Carbonneau, A. (2001) Influence of water deficits on grape berry growth. Vitis 40, 141-145.

Ojeda, H., Andary, C., Kraeva, E., Carbonneau, A. És Deloire, A. (2002) Influence of preand postveraison water deficit on synthesis and concentration of skin phenolic compounds during berry growth of Vitis vinifera cv. Shiraz. Am. J. Enol. Vitic. 53, 261267. http://www.ajevonline.org/content/53/4/261.1.abstract

Ollé, D., Guiraud, J.L., Souquet, J.M., Terrier, N., Ageorges, A., Cheynier, V. És Verries, C. (2011) Effect of pre- and post-veraison water deficit on proanthocyanidin and anthocyanin accumulation during Shiraz berry development. Aust. J. Grape Wine Res. 17, 90-100. http://dx.doi.org/10.1111/j.1755-0238.2010.00121.x

Ortega-Heras, M., PÉreZ-MagariÑo, S. És GonZÁlez-SAnjosé, M.L. (2012) Comparative study of the use of maceration enzymes and cold pre-fermentative maceration on phenolic and anthocyanic composition and colour of a Mencía red wine. LWT-Food Sci. Technol. 48, 1-8. http://dx.doi.org/10.1016/j.lwt.2012.03.012

Ortega-Regules, A., Romero-Cascales, I., Ros-Garcia, J.M., LoPez-RocA, J.M. És GomezPlAZA, E. (2006) A first approach towards the relationship between grape skin cell-wall composition and anthocyanin extractability. Anal. Chim. Acta 563, 26-32. http://dx.doi.org/10.1016/j.aca.2005.12.024

Ortega-Regules, A., Romero-Cascales, I., Ros Garcia, J.M., Bautista-Ortin, A.B., LOPEZ-RoCA, J.M., FernandeZ-FernandeZ, J.I. ÉS GoMEZ- PlazA, E. (2008) Anthocyanins and tannins in four grape varieties (Vitis vinifera L.) - Evolution of their content and extractability. J. Int. Sci. Vigne Vin. 42, 147-156.

Palliotti, A., Gardi, T., Berrios, J.G., Civardi, S. ÉS PONI, S. (2012) Early source limitation as a tool for yield control and wine quality improvement in a high-yielding red Vitis $\begin{array}{llllll}\text { vinifera L } & \text { L } & \text { cultivar. } & \text { Hortic. } & 145, & 16 .\end{array}$ http://dx.doi.org/10.1016/j.scienta.2012.07.019

Palliotti, A., Panara, F., Silvestroni, O., Lanari, V., Sabbatini, P., Howell, G.S., Gatti, M. ÉS PONI, S. (2013) Influence of mechanical postveraison leaf removal apical to the cluster zone on delay of fruit ripening in Sangiovese (Vitis vinifera L.) grapevines. Aust. J. Grape Wine Res. 19, 369-377. http://dx.doi.org/10.1111/ajgw.12033

PÁsti, G. (2002) Kékszőlő-feldolgozási technológiák elemzése a minőségi vörösborkészítés függvényében. PhD értekezés., Szent István Egyetem, Élelmiszertudományi Doktori Iskola, Budapest.

Pérez-LóPez, F.R., Chedraui, P., Haya, J. És Cuadros, J.L. (2009) Effects of the Mediterranean diet on longevity and age-related morbid conditions. Maturitas 64, 67-79. http://dx.doi.org/10.1016/j.maturitas.2009.07.013

PÉReZ-MAGAriÑo, S. ÉS GONZÁlez-SAn José, M.L. (2006) Polyphenols and colour variability of red wines made from grapes harvested at different ripeness grade. Food Chem. 96, 197208. http://dx.doi.org/10.1016/j.foodchem.2005.02.021

Petrie, P.R., CoOley, N.M. ÉS ClingelefFer, P.R. (2004) The effect of post-veraison water deficit on yield components and maturation of irrigated Shiraz (Vitis vinifera L.) in the current and following season. Aust. J. Grape Wine Res. 10, 203-215. http://dx.doi.org/10.1111/j.1755-0238.2004.tb00024.x

Pettorelli, N. (2013) The normalized difference vegetation index. Oxford University Press.

Peyrot des Gachons, C. És Kennedy, J.A. (2003) Direct method for determining seed and skin proanthocyanidin extraction into red wine. J. Agric. Food Chem. 51, 5877-5881. http://dx.doi.org/10.1021/jf034178r

Poni, S., Casalini, L., Bernizzoni, F., Civardi, S. ÉS InTRIERI, C. (2006) Effects of early defoliation on shoot photosynthesis, yield components, and grape composition. Am. J. Enol. Vitic. 57, 397-407. http://www.ajevonline.org/content/57/4/397.abstract 
Poni, S., Bernizzoni, F., Civardi, S. ÉS LiBelli, N. (2009) Effects of pre-bloom leaf removal on growth of berry tissues and must composition in two red Vitis vinifera L. cultivars. Aust. J. Grape Wine Res. 15, 185-193. http://dx.doi.org/10.1111/j.1755-0238.2008.00044.x

Porro, D., RAMPONI, M., TOMASI, T., Rolle, L. ÉS PONI, S. (2010) Nutritional implications of water stress in grapevine and modifications of mechanical properties of berries. Acta Hortic. 868, 73-80.

Porter, L.J., Hrstich, L.N. ÉS Chan, B.G. (1985) The conversion of procyanidins and prodelphinidins to cyanidin and delphinidin. Phytochemistry 25, 223-230. http://dx.doi.org/10.1016/S0031-9422(00)94533-3

Poussier, M., GuillouX-Benatier, M., Torres, M., Heras, E. ÉS Adrian, M. (2003) Influence of different maceration techniques and microbial enzymatic activities on wine stilbene $\begin{array}{lllll}\text { content. } & \mathrm{Am} . & \mathrm{J} & \mathrm{Enol} \text {. Vitic. }\end{array}$ http://www.ajevonline.org/content/54/4/261.abstract

Prajitna, A., Dami, I.E., Steiner, T.E., Ferree, D.C., Scheerens, J.C. És Schwartz, S.J. (2007) Influence of cluster thinning on phenolic composition, resveratrol, and antioxidant capacity in Chambourcin wine. Am. J. Enol. Vitic. 58, 346-350. http://www.ajevonline.org/content/58/3/346.abstract

Prieur, C., Rigaud, J., Cheynier, V. És Moutounet, M. (1994) Oligomeric and polymeric procyanidins from grape seeds. Phytochemistry 36, 781-784. http://dx.doi.org/10.1016/s0031-9422(00)89817-9

RENAUD, S. ÉS DE LORGERIL, M. (1992) Wine, alcohol, platelets, and the French paradox for coronary heart disease. The Lancet 339, 1523-1526. http://dx.doi.org/10.1016/0140$\underline{6736(92) 91277-\mathrm{f}}$

Rentzsch, M., Wilkens, A. És Winterhalter, P. (2009) Non-flavonoid Phenolic Compounds. In Wine Chemistry and Biochemistry. MorenO-ARriBAS, M.V. És PolO, M.C. (eds.), pp. 509-527. Springer New York. http://dx.doi.org/10.1007/978-0-387-74118-5_23

RibÉREAU-Gayon, P. ÉS StOnestreet, E. (1965) Le dosage des anthocyanes dans le vin rouge. Bull. Soc. Chim. Fr. 9, 2649-2652.

Ribéreau-Gayon, P., Glories, Y., Maujean, A. És Dubourdieu, D. (2006) Handbook of enology, vol 2: The chemistry of wine and stabilization and treatments. Wiley, New York.

Río Segade, S., Rolle, L., Gerbi, V. És OrRiols, I. (2008a) Phenolic ripeness assessment of grape skin by texture analysis. J. Food Comp. Anal. 21, 644-649. http://dx.doi.org/10.1016/j.jfca.2008.06.003

Río Segade, S., VAZQueZ, E.S. ÉS LOSADA, E.D. (2008b) Influence of ripeness grade on accumulation and extractability of grape skin anthocyanins in different cultivars. J. Food Comp. Anal. 21, 599-607. http://dx.doi.org/10.1016/j.jfca.2008.04.006

Río Segade, S., Giacosa, S., Gerbi, V. ÉS Rolle, L. (2011a) Berry skin thickness as main texture parameter to predict anthocyanin extractability in winegrapes. LWT-Food Sci. Technol. 44, 392-398. http://dx.doi.org/10.1016/j.lwt.2010.09.004

Río Segade, S., OrRiols, I., Giacosa, S. ÉS Rolle, L. (2011b) Instrumental texture analysis parameters as winegrapes varietal markers and ripeness predictors. Int. J. Food Prop. 14, 1318-1329. http://dx.doi.org/10.1080/10942911003650320

Río Segade, S., VÁzquez, E.S., OrRiols, I., Giacosa, S. És Rolle, L. (2011c) Possible use of texture characteristics of winegrapes as markers for zoning and their relationship with anthocyanin extractability index. Int. J. Food Sci. Tech. 46, 386-394. http://dx.doi.org/10.1111/j.1365-2621.2010.02489.x

Río Segade, S., Giacosa, S., Torchio, F., De Palma, L., Novello, V., Gerbi, V. És Rolle, L. (2013) Impact of different advanced ripening stages on berry texture properties of 'Red Globe' and 'Crimson Seedless' table grape cultivars (Vitis vinifera L.). Sci. Hortic. 160, 313-319. http://dx.doi.org/10.1016/j.scienta.2013.06.017 
Ristic, R., Downey, M.O., Iland, P.G., Bindon, K., Francis, I.L., Herderich, M. És RoBINSON, S.P. (2007) Exclusion of sunlight from Shiraz grapes alters wine colour, tannin and sensory properties. Aust. J. Grape Wine Res. 13, 53-65. http://dx.doi.org/10.1111/j.1755-0238.2007.tb00235.x

Roby, G., Harbertson, J.F., Adams, D.A. ÉS Matthews, M.A. (2004) Berry size and vine water deficits as factors in winegrape composition: Anthocyanins and tannins. Aust. J. Grape Wine Res. 10, 100-107. http://dx.doi.org/10.1111/j.1755-0238.2004.tb00012.x

RoBY, G. ÉS MATTHEWS, M.A. (2004) Relative proportions of seed, skin and flesh, in ripe berries from Cabernet Sauvignon grapevines grown in a vineyard either well irrigated or under water deficit. Aust. J. Grape Wine Res. 10, 74-82. http://dx.doi.org/10.1111/j.17550238.2004.tb00009.x

Rodríguez-Pulido, F.J., Ferrer-Gallego, R., Lourdes GonZÁlez-Miret, M., RivasGonZalo, J.C., Escribano-BAilón, M.T. És Heredia, F.J. (2012a) Preliminary study to determine the phenolic maturity stage of grape seeds by computer vision. Anal. Chim. Acta 732, 78-82. http://dx.doi.org/10.1016/j.aca.2012.01.005

Rodríguez-Pulido, F.J., Gómez-Robledo, L., Melgosa, M., Gordillo, B., GonzÁlezMiRET, M.L. ÉS HEREDIA, F.J. (2012b) Ripeness estimation of grape berries and seeds by image analysis. Comput. Electron. Agric. 82, 128-133. http://dx.doi.org/10.1016/j.compag.2012.01.004

Rolle, L., TORCHIO, F., ZEPPA, G. ÉS GERBI, V. (2008) Anthocyanin extractability assessment of grape skins by texture analysis. J. Int. Sci. Vigne Vin. 42, 157-162.

Rolle, L., TorChio, F., ZEPPA, G. ÉS GERBI, V. (2009) Relationship between skin break force and anthocyanin extractability at different ripening stages. Am. J. Enol. Vitic. 60, 93-97. http://www.ajevonline.org/content/60/1/93.short

Rolle, L., Giacosa, S., Gerbi, V. ÉS Novello, V. (2011a) Comparative study of texture properties, color characteristics, and chemical composition of ten white table-grape varieties. Am. J. Enol. Vitic. 62, 49-56. http://dx.doi.org/10.5344/ajev.2010.10029

Rolle, L., Río Segade, S., Torchio, F., Giacosa, S., Cagnasso, E., Marengo, F. És Gerbi, V. (2011b) Influence of grape density and harvest date on changes in phenolic composition, phenol extractability indices, and instrumental texture properties during ripening. $J$. Agric. Food Chem. 59, 8796-8805. http://dx.doi.org/10.1021/jf201318x

Rolle, L., TorChio, F., FerrandinO, A. ÉS GuidOni, S. (2011c) Influence of wine-grape skin hardness on the kinetics of anthocyanin extraction. Int. J. Food Prop. 15, 249-261. http://dx.doi.org/10.1080/10942911003778022

Rolle, L., Giacosa, S., Torchio, F. ÉS Río Segade, S. (2012a) Changes in acoustic and mechanical properties of Cabernet Sauvignon seeds during ripening. Am. J. Enol. Vitic. 63, 413-418. http://dx.doi.org/10.5344/ajev.2012.11054

Rolle, L., Siret, R., Río Segade, S., MAury, C., Gerbi, V. ÉS JourJon, F. (2012b) Instrumental texture analysis parameters as markers of table-grape and winegrape quality: A review. Am. J. Enol. Vitic. 63, 11-28. http://dx.doi.org/10.5344/ajev.2011.11059

Romero-CAscales, I., Ortega-Regules, A., Lopez- RoCA, J.M., FERnANDEZ-FERnANDEZ, J.I. ÉS GoMez-PlAZA, E. (2005) Differences in anthocyanin extractability from grapes to wines according to variety. Am. J. Enol. Vitic. 56, 212-219. http://www.ajevonline.org/content/56/3/212.abstract

Romero-CAscales, I., FernándeZ-FernándeZ, J.I., Ros-García, J.M., LÓPEZ-Roca, J.M. ÉS GómEZ-PlAZA, E. (2008) Characterisation of the main enzymatic activities present in six commercial macerating enzymes and their effects on extracting colour during winemaking of Monastrell grapes. Int. J. Food Sci. Tech. 43, 1295-1305. http://dx.doi.org/10.1111/j.1365-2621.2007.01608.x

ROMEYER, F.M., MACHEIX, J.-J. ÉS SAPIS, J.-C. (1985) Changes and importance of oligomeric procyanidins during maturation of grape seeds. Phytochemistry 25, 219-221. http://dx.doi.org/10.1016/S0031-9422(00)94532-1 
RyAn, J.M. ÉS ReVILlA, E. (2003) Anthocyanin composition of Cabernet Sauvignon and Tempranillo grapes at different stages of ripening. J. Agric. Food Chem. 51, 3372-3378. http://dx.doi.org/10.1021/jf020849u

SACCHI, K.L., BISSON, L.F. ÉS ADAMS, D.O. (2005) A review of the effect of winemaking techniques on phenolic extraction in red wines. Am. J. Enol. Vitic. 56, 197-206. http://www.ajevonline.org/content/56/3/197.abstract

SADRAS, V.O. ÉS MORAN, M.A. (2012) Elevated temperature decouples anthocyanins and sugars in berries of Shiraz and Cabernet Franc. Aust. J. Grape Wine Res. 18, 115-122. http://dx.doi.org/10.1111/j.1755-0238.2012.00180.x

SAINT-CRICQ, N., VIVAS, N. ÉS GLORIES, Y. (1998) Maturité phénolique: définition et contrôle. Rev. Fr. Oenol. 173, 22-25.

Santamaria, A.R., Mulinacci, N., Valletta, A., InNOCEnTI, M. És PASQua, G. (2011) Effects of elicitors on the production of resveratrol and viniferins in cell cultures of Vitis vinifera L. cv Italia. J. Agric. Food Chem. 59, 9094-9101. http://dx.doi.org/10.1021/jf201181n

SAnTESteBAn, L.G., MirandA, C. És RoYO, J.B. (2011) Regulated deficit irrigation effects on growth, yield, grape quality and individual anthocyanin composition in Vitis vinifera L. cv. 'Tempranillo'. Agric. Water Manag. 98, 1171-1179. http://dx.doi.org/10.1016/j.agwat.2011.02.011

SATO, M., SuZuKi, Y., OKUdA, T. ÉS YOKOTSUKA, K. (1997) Contents of resveratrol, piceid, and their isomers in commercially available wines made from grapes cultivated in Japan. Biosci. Biotechnol. Biochem. 61, 1800-1805. http://dx.doi.org/10.1271/bbb.61.1800

Schmitт, A. (2005) Aktuelle Weinanalytik. Heller Chemie- und Verwaltungsgesellschaft, Schw bisch Hall.

SCHULTZ, H.R. (1996) Water relations and photosynthesis responses of two grapevine cultivars of different geographical origin during water stress. Acta Hortic. 427, 251-266.

Schultz, H.R. (2000) Climate change and viticulture: A European perspective on climatology, carbon dioxide and UV-B effects. Aust. J. Grape Wine Res. 6, 2-12. http://dx.doi.org/10.1111/j.1755-0238.2000.tb00156.x

SCHUlTZ, H.R. (2003) Differences in hydraulic architecture account for near-isohydric and anisohydric behaviour of two field-grown Vitis vinifera L. cultivars during drought. Plant Cell Environ. 26, 1393-1405. http://dx.doi.org/10.1046/j.1365-3040.2003.01064.x

SIEMANN, E.H. ÉS CREASY, L.L. (1992) Concentration of the phytoalexin resveratrol in wine. Am. J. Enol. Vitic. 43, 49-52. http://www.ajevonline.org/content/43/1/49.abstract

Singh Brar, H., Singh, Z., SwinnY, E. ÉS CAMERON, I. (2008) Girdling and grapevine leafroll associated viruses affect berry weight, colour development and accumulation of anthocyanins in 'Crimson Seedless' grapes during maturation and ripening. Plant Sci. 175, 885-897. http://dx.doi.org/10.1016/j.plantsci.2008.09.005

Singleton, V.L. ÉS ROSSI, J.A. (1965) Colorimetry of total phenolics with phosphomolybdicphosphotungstic acid reagents. Am. J. Enol. Vitic. 16, 144-158. http://www.ajevonline.org/cgi/content/abstract/16/3/144

Somers, T.C. (1971) The polymeric nature of wine pigments. Phytochemistry 10, 2175-2186. http://dx.doi.org/10.1016/S0031-9422(00)97215-7

Souquet, J.-M., Cheynier, V., Brossaud, F. ÉS Moutounet, M. (1996) Polymeric proanthocyanidins from grape skins. Phytochemistry 43, 509-512. http://dx.doi.org/10.1016/0031-9422(96)00301-9

Souquet, J.-M., Labarbe, B., Le Guernevé, C., Cheynier, V. És Moutounet, M. (2000) Phenolic composition of grape stems. J. Agric. Food Chem. 48, 1076-1080. http://dx.doi.org/10.1021/jf991171u

Spayd, S.E., TARARA, J.M., MeE, D.L. És Ferguson, J.C. (2002) Separation of sunlight and temperature effects on the composition of Vitis vinifera cv. Merlot berries. Am. J. Enol. Vitic. 53, 171-182. http://www.ajevonline.org/content/53/3/171.abstract 
Sternad Lemut, M., Trost, K., Sivilotti, P. És Vrhovsek, U. (2011) Pinot Noir grape colour related phenolics as affected by leaf removal treatments in the Vipava Valley. J. Food Comp. Anal. 24, 777-784. http://dx.doi.org/10.1016/j.jfca.2011.03.003

SugÁR, I. (1981) Az egri vörös bor termelésének múltjából: Az egri bikavér kialakulása. Agrártörténeti Szemle 23, 104-132.

Sun, B.H., Spranger, I., Roque-do-Vale, F., Leandro, C. És Belchior, P. (2001) Effect of different winemaking technologies on phenolic composition in Tinta Miuda red wines. $J$. Agric. Food Chem. 49, 5809-5816. http://dx.doi.org/10.1021/jf010661v

Sweetman, C., Deluc, L.G., Cramer, G.R., Ford, C.M. ÉS SoOle, K.L. (2009) Regulation of malate metabolism in grape berry and other developing fruits. Phytochemistry 70, 13291344. http://dx.doi.org/10.1016/j.phytochem.2009.08.006

Terrier, N., Poncet-Legrand, C. ÉS Cheynier, V. (2009) Flavanols, flavonols and dihydroflavonols. In Wine Chemistry and Biochemistry. MORENO-ARRIBAS, M.V. ÉS PolO, M.C. (eds.), pp. 463-507. Springer New York. http://dx.doi.org/10.1007/978-0387-74118-5 22

Torchio, F., CAgnasso, E., Gerbi, V. És Rolle, L. (2010) Mechanical properties, phenolic composition and extractability indices of Barbera grapes of different soluble solids contents from several growing areas. Anal. Chim. Acta 660, 183-189. http://dx.doi.org/10.1016/j.aca.2009.10.017

van Leeuwen, C., Friant, P., Chone, X., Tregoat, O., Koundouras, S. És Dubourdieu, D. (2004) Influence of climate, soil, and cultivar on terroir. Am. J. Enol. Vitic. 55, 207-217. http://www.ajevonline.org/content/55/3/207.abstract

VAN LEEUWEN, C. (2009) Soils and terroir expression in wines. In Soil and Culture. LANDA, E.R. ÉS FELlER, C. (eds.), pp. 453-465. Springer Netherlands. http://dx.doi.org/10.1007/97890-481-2960-7 28

Vidal, S., Francis, L.I., Guyot, S., Marnet, N., KwiatKowski, M., Gawel, R., Cheynier, V. ÉS WATERS, E.J. (2003) The mouth-feel properties of grape and apple proanthocyanidins in a wine-like medium. J. Sci. Food Agric. 83, 564-573. http://dx.doi.org/10.1002/jsfa.1394

Vidal, S., Hayasaka, Y., Meudec, E., Cheynier, V. És Skouroumounis, G. (2004) Fractionation of grape anthocyanin classes using multilayer coil countercurrent chromatography with step gradient elution. J. Agric. Food Chem. 52, 713-719. http://dx.doi.org/10.1021/jf034906a

Vouillamoz, J.F. ÉS GRANDO, M.S. (2006) Genealogy of wine grape cultivars: /Pinot/' is related to / 'Syrah/'. Heredity 97, 102-110. http://dx.doi.org/10.1038/sj.hdy.6800842

WebB, L.B., Whetton, P.H., Bhend, J., Darbyshire, R., Briggs, P.R. És BARlow, E.W.R. (2012) Earlier wine-grape ripening driven by climatic warming and drying and management practices. Nat. Clim. Change 2, 259-264. http://dx.doi.org/10.1038/nclimate1417

Webb, L.B., Watterson, I., Bhend, J., Whetton, P.H. És BArlow, E.W.R. (2013) Global climate analogues for winegrowing regions in future periods: projections of temperature and precipitation. Aust. J. Grape Wine Res. 19, 331-341. http://dx.doi.org/10.1111/ajgw.12045

Wood, C., Siebert, T.E., Parker, M., Capone, D.L., Elsey, G.M., Pollnitz, A.P., EgGers, M., Meier, M., Vössing, T., Widder, S., Krammer, G., Sefton, M.A. És Herderich, M.J. (2008) From wine to pepper: Rotundone, an obscure sesquiterpene, is a potent spicy aroma compound. J. Agric. Food Chem. 56, 3738-3744. http://dx.doi.org/10.1021/jf800183k

Yamane, T., JeOng, S.T., Goto-Yamamoto, N., Koshita, Y. ÉS KobAYASHI, S. (2006) Effects of temperature on anthocyanin biosynthesis in grape berry skins. Am. J. Enol. Vitic. 57, 54-59. http://www.ajevonline.org/content/57/1/54.abstract 
ZHAO, J., DAVIS, L.C. ÉS VERPOORTE, R. (2005) Elicitor signal transduction leading to production of plant secondary metabolites. Biotechnol. Adv. 23, 283-333. http://dx.doi.org/10.1016/j.biotechadv.2005.01.003

Zouid, I., Siret, R., Mehinagic, E., Maury, C., Chevalier, M. És Jourjon, F. (2010) Evolution of grape berries during ripening: investigations into the links between their mechanical properties and the extractability of their skin anthocyanins. J. Int. Sci. Vigne Vin. 44, 87-99.

Zsófi, Z., GÁl, L., SzIlÁgyi, Z., SzüCs, E., Marschall, M., NAGy, Z. És BÁlo, B. (2009) Use of stomatal conductance and pre-dawn water potential to classify terroir for the grape variety Kékfrankos. Aust. J. Grape Wine Res. 15, 36-47. http://dx.doi.org/10.1111/j.1755$\underline{0238.2008 .00036 . \mathrm{x}}$

ZSÓFI, Z., TÓTH, E., RuSJAN, D. ÉS BÁLO, B. (2011) Terroir aspects of grape quality in a cool climate wine region: Relationship between water deficit, vegetative growth and berry $\begin{array}{lllll}\text { sugar concentration. } & \text { Sci. Hortic. } & \text { 427, }\end{array}$ http://dx.doi.org/10.1016/j.scienta.2010.11.014

Zsófi, Z., Villangó, S., PÁlfi, Z., TóTh, E. ÉS BÁlO, B. (2014) Texture characteristics of the grape berry skin and seed (Vitis vinifera L. cv. Kékfrankos) under postveraison water deficit. Sci. Hortic. 172, 176-182. http://dx.doi.org/10.1016/j.scienta.2014.04.008

Internetes forrásmunkák:

OIV (2014) Compendium of international methods of wine and must analysis vol. 1 http://www.oiv.int/oiv/info/enmethodesinternationalesvin?lang=en

SCOLLARY, G.R. (2010) GWRDC Tannin Review. http://research.agwa.net.au/wpcontent/uploads/2012/09/GWR-0905.pdf

WIKIPEDIA (2014) http://en.wikipedia.org/wiki/Resveratrol

http://plantgrape.plantnet-project.org/cepage/Syrah\%20N

http://www.hnt.hu

http://www.fomi.hu/portal/index.php/projektjeink/vingis/vingis-oem-ofj-terkepek 


\section{ÁBRAJEGYZÉK}

1. ábra - Egyszerü fenol vegyület felépítése...

2. ábra - A bor fenolos összetevőinek csoportosítása. A szaggatott vonallal jelölt reakcióutak kevésbé valószínűek, mint azok, amelyek folyamatos vonallal jelöltek (SCOLLARY 2010) .....

3. ábra - A szőlő és a bor fenolos savai (MonAGAS et al. 2005) ................................................10

4. ábra - 1: transz-rezveratrol; 2: cisz-rezveratrol; 3: transz-piceid; 4: cisz-piceid; Glc: glükóz.11 (RENTZSCH et al. 2009)

5. ábra - A szénatomok számozása és a gyürúk betűjelzése flavonoid típusú fenolos vegyületek esetén (SCOLLARY 2010)

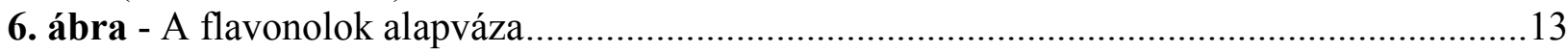

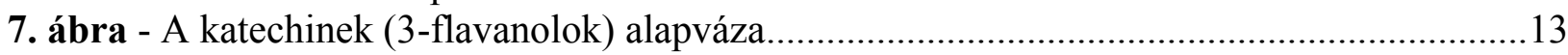

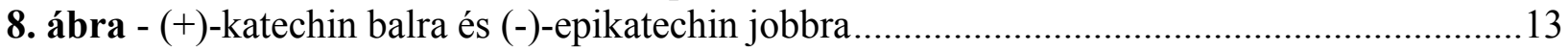

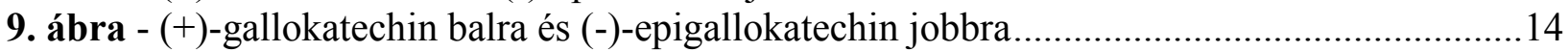

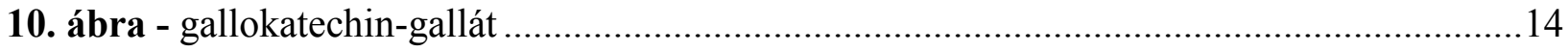

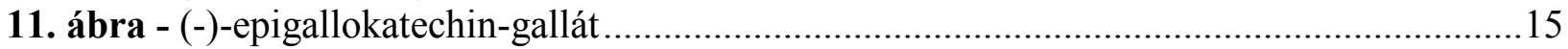

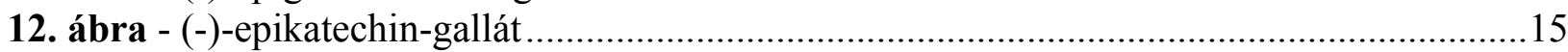

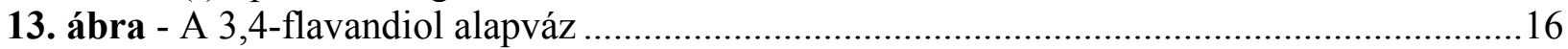

14. ábra - Példa egy (+)-katechinből (Cat) és (-)-epikatechinből (Epi) felépülö tannin

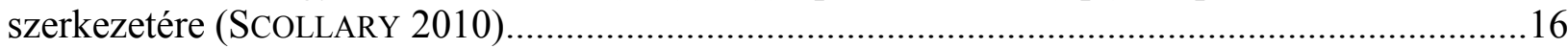

15. ábra - A cukormolekulára acileződött acetil (balra), p-kumársav (középen), kávésav (jobbra)

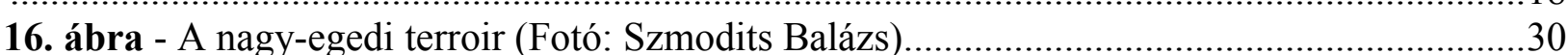

17. ábra - A kísérlet helyszíne a Nagy-Eged-hegy dülőn belül (Forrás: Google Earth) ...............31

18. ábra - Royat-kordon müvelésmód (LŐRINCZ ÉS BARÓCSI 2010) ..........................................32

19. ábra - A Syrah levele 20. ábra - A Syrah termése ............35

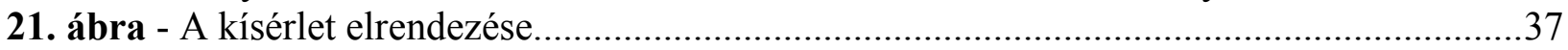

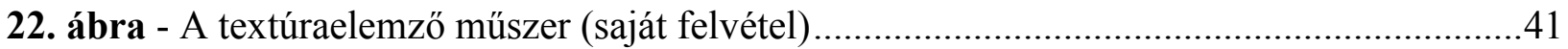

23. ábra - A textúraelemzőre felszerelhető szondák (saját felvétel) ........................................42

24. ábra - A bogyóhéj keménységéhez, a vastagságához, a magkeménységhez és a bogyókeménységhez tartozó tipikus reogrammok vázlatosan (balról jobbra) (LETAIEF et al. 2008a)

25. ábra - A ,farok effektus” mérési hibát jelent a héjvastagság meghatározása során (saját

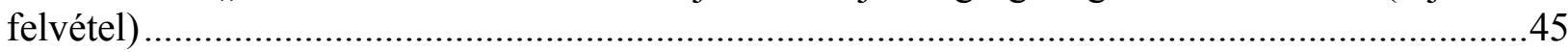

26. ábra - Mikrovinifikációs borkészítés (saját felvétel) …..................................................47

27. ábra - Az átlagos bogyótömeg alakulása 2012-ben és 2013-ban .........................................51

28. ábra - A kontroll (C) és kezelt (LM) mustminták cukortartalmának változása az érés során,

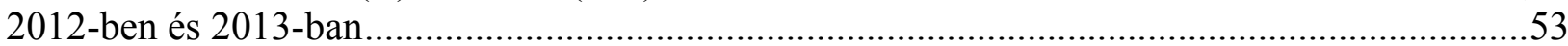

29. ábra - A kontroll $(\mathrm{C})$ és kezelt (LM) mustminták titrálható savtartalmának változása az érés

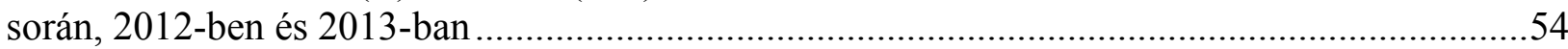
30. ábra - A kontroll $(\mathrm{C})$ és kezelt (LM) mustminták pH-jának változása az érés során, 2012-ben és 2013-ban.

31. ábra - A kontroll (C) és kezelt (LM) bogyóminták összes antocianintartalmának (A1) változása az érés során, 2012-ben és 2013-ban

32. ábra - A kontroll $(\mathrm{C})$ és kezelt (LM) bogyóminták összes kivonható antocianintartalmának $(A 3,4)$ változása az érés során, 2012-ben és 2013-ban.............................................................58

33. ábra - A kontroll (C) és kezelt (LM) bogyóminták kivonhatósági indexének (EA\%) változása az érés során, 2012-ben és 2013-ban

34. ábra - A kontroll (C) és kezelt (LM) bogyóminták magérettségi indexének (SM\%) változása

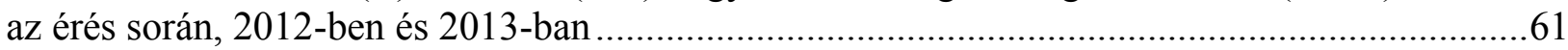

35. ábra - A héjkeménység $\left(F_{\text {sk }}\right)$ alakulása 2012-ben és 2013-ban ...........................................63 
36. ábra - A héj Young modulusának $\left(\mathrm{E}_{\mathrm{sk}}\right)$ alakulása 2012-ben és 2013-ban ............................64

37. ábra - A héj átszakításához szükséges erő $\left(\mathrm{W}_{\text {sk }}\right)$ alakulása 2012-ben és 2013-ban................65

38. ábra - A bogyókeménység (BH) alakulása 2012-ben és 2013-ban ...................................66

39. ábra - A héjvastagság $\left(\mathrm{Sp}_{\mathrm{sk}}\right)$ alakulása 2012-ben és 2013-ban..........................................68

40. ábra - A kísérleti borok alkoholtartalmának alakulása 2012-ben és 2013-ban ....................71

41. ábra - A kísérleti borok titrálható savtartalmának alakulása 2012-ben és 2013-ban..............72

42. ábra - A kísérleti borok pH-jának alakulása 2012-ben és 2013-ban ....................................73

43. ábra - A kísérleti borok cukormentes extrakttartalmának alakulása 2012-ben és 2013-ban..74

44. ábra - A kísérleti borok összes polifenoltartalmának alakulása 2012-ben és 2013-ban.........75

45. ábra - A kísérleti borok leukoantocianintartalmának alakulása 2012-ben és 2013-ban.........76

46. ábra - A kísérleti borok antocianintartalmának alakulása 2012-ben és 2013-ban.................78

47. ábra - A kísérleti borok katechintartalmának alakulása 2012-ben és 2013-ban....................79

48. ábra - A kísérleti borok színintenzitásának alakulása 2012-ben és 2013-ban .......................81

49. ábra - A kísérleti borok színárnyalatának alakulása 2012-ben és 2013-ban .........................82

50. ábra - A kísérleti borok sósav $(\mathrm{HCl})$ indexének alakulása 2012-ben és 2013-ban.................83

51. ábra - A kísérleti borok zselatin indexének alakulása 2012-ben és 2013-ban.......................85

52. ábra - A kísérleti borok transz-rezveratrol tartalmának alakulása 2012-ben és 2013-ban .....87

53. ábra - A kísérleti borok transz-piceid tartalmának alakulása 2012-ben és 2013-ban ............88

54. ábra - A kísérleti borok cisz-piceid tartalmának alakulása 2012-ben és 2013-ban .................89

55. ábra - A kísérleti borok összes rezveratroltartalmának alakulása 2012-ben és 2013-ban......90

56. ábra - A 2011-es kísérleti borok profilanalízise ..............................................................992

57. ábra - A 2012-es évjárat első szüreti időpontból származó borainak profilanalízise .............93

58. ábra - A 2012-es évjárat második szüreti időpontból származó borainak profilanalízise......94

59. ábra - A 2012-es évjárat harmadik szüreti időpontból származó borainak profilanalízise ....95

60. ábra - A 2013-as évjárat első szüreti időpontból származó borainak profilanalízise .............96

61. ábra - A 2013-as évjárat második szüreti időpontból származó borainak profilanalízise......97

62. ábra - A 2013-as évjárat második szüreti időpontból származó borainak profilanalízise.......98 


\section{TÁBLÁZATJEGYZÉK}

1. táblázat - A textúraelemzővel elvégezhető mérések LETAIEF et al. (2008a) nyomán..............44

2. táblázat - A termésmennyiség alakulása a kísérlet három évében ....................................50

3. táblázat - Az átlagos bogyótömeg alakulása 2011-ben .....................................................51

4. táblázat - A must rutinanalitikai értékeinek változása az érés során, 2011-ben......................52

5. táblázat - A szőlő fenolos érettsége a 2011-es évjáratban...................................................56

6. táblázat - A szőlő fizikai paramétereinek változása az érés során a 2011-es évjáratban .........62

7. táblázat - A 2011-es kísérleti borok analitikája................................................................69

8. táblázat - A 2011-es kísérleti borok rezveratroltartalma, n.d. = nem detektálható ..................86 


\section{MELLÉKLETEK}

M1. A Nagy-Eged-hegy dülő elhelyezkedése

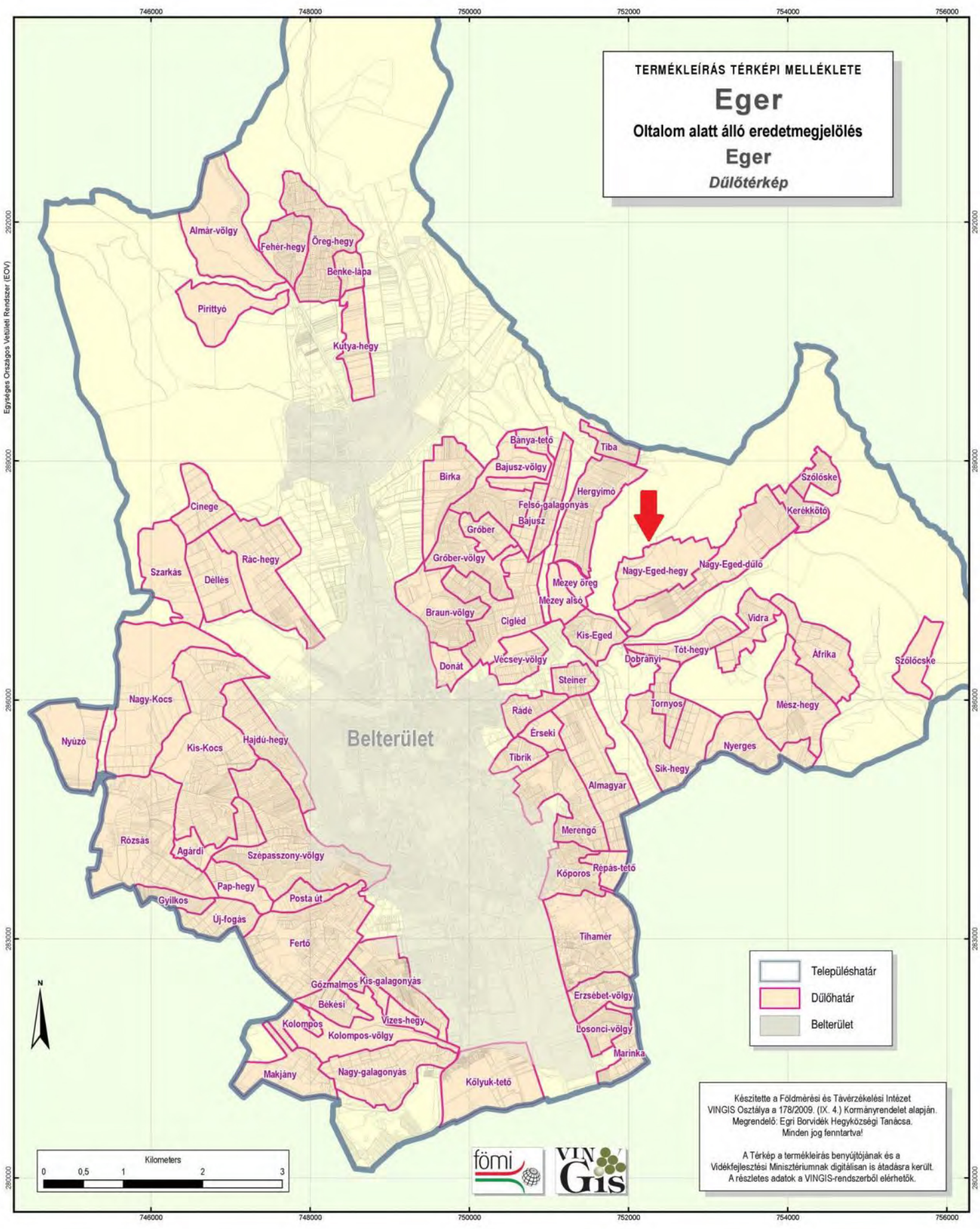

A Nagy-Eged-hegy dűlő elhelyezkedése az egri dűlők között (Forrás: Az Egri termékleírás

2. melléklete: http://www.fomi.hu/portal/index.php/projektjeink/vingis/vingis-oem-ofj-terkepek) 
M2. Infravörös és NDVI felvételek a kísérlet helyszínéről

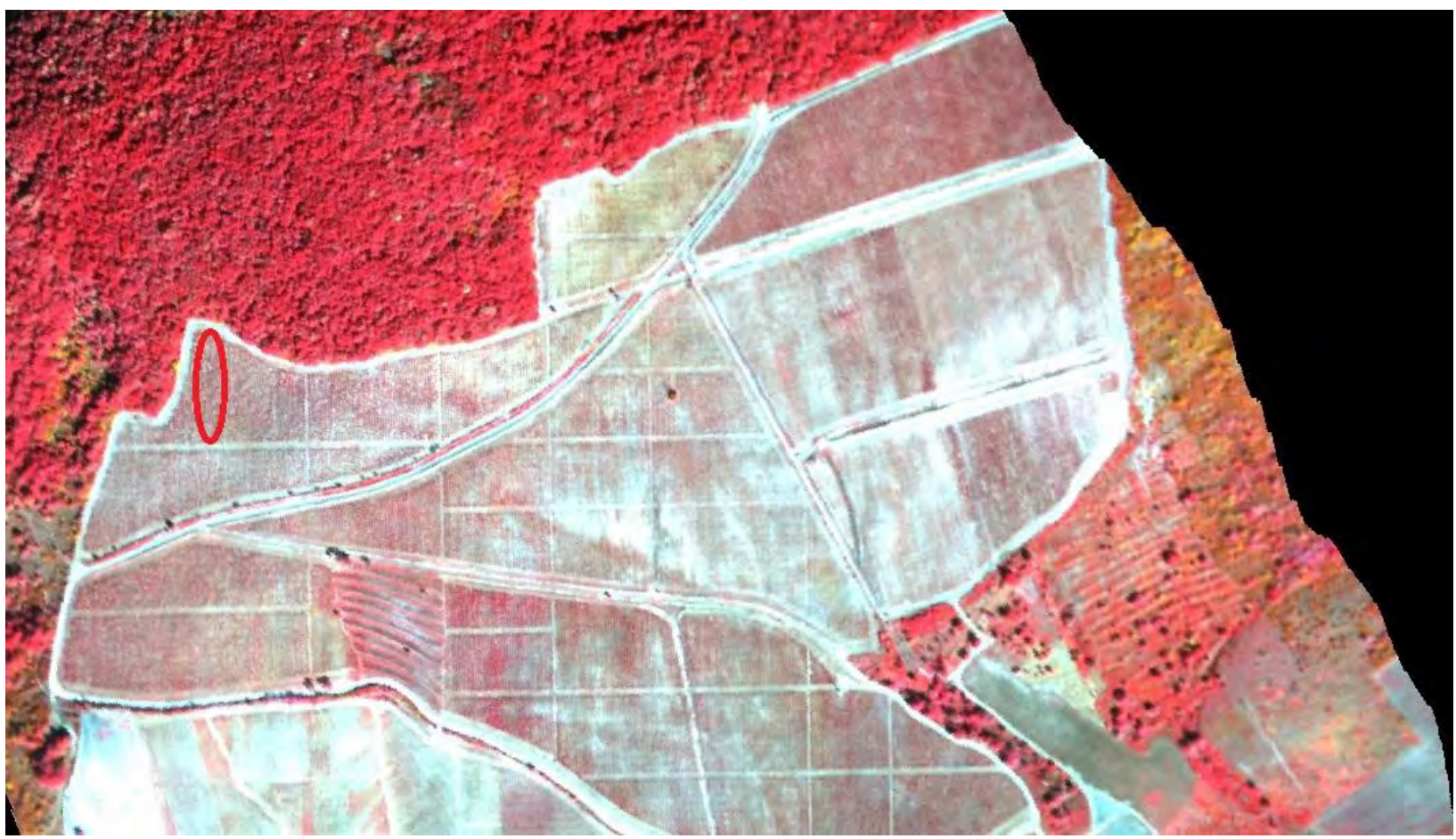

A visszavert fény intenzitása a közeli infravörös tartományban (Forrás: Károly Róbert Főiskola

Távérzékelési és Vidékfejlesztési Kutatóintézete) A piros ellipszis a kísérlet helyét jelöli.

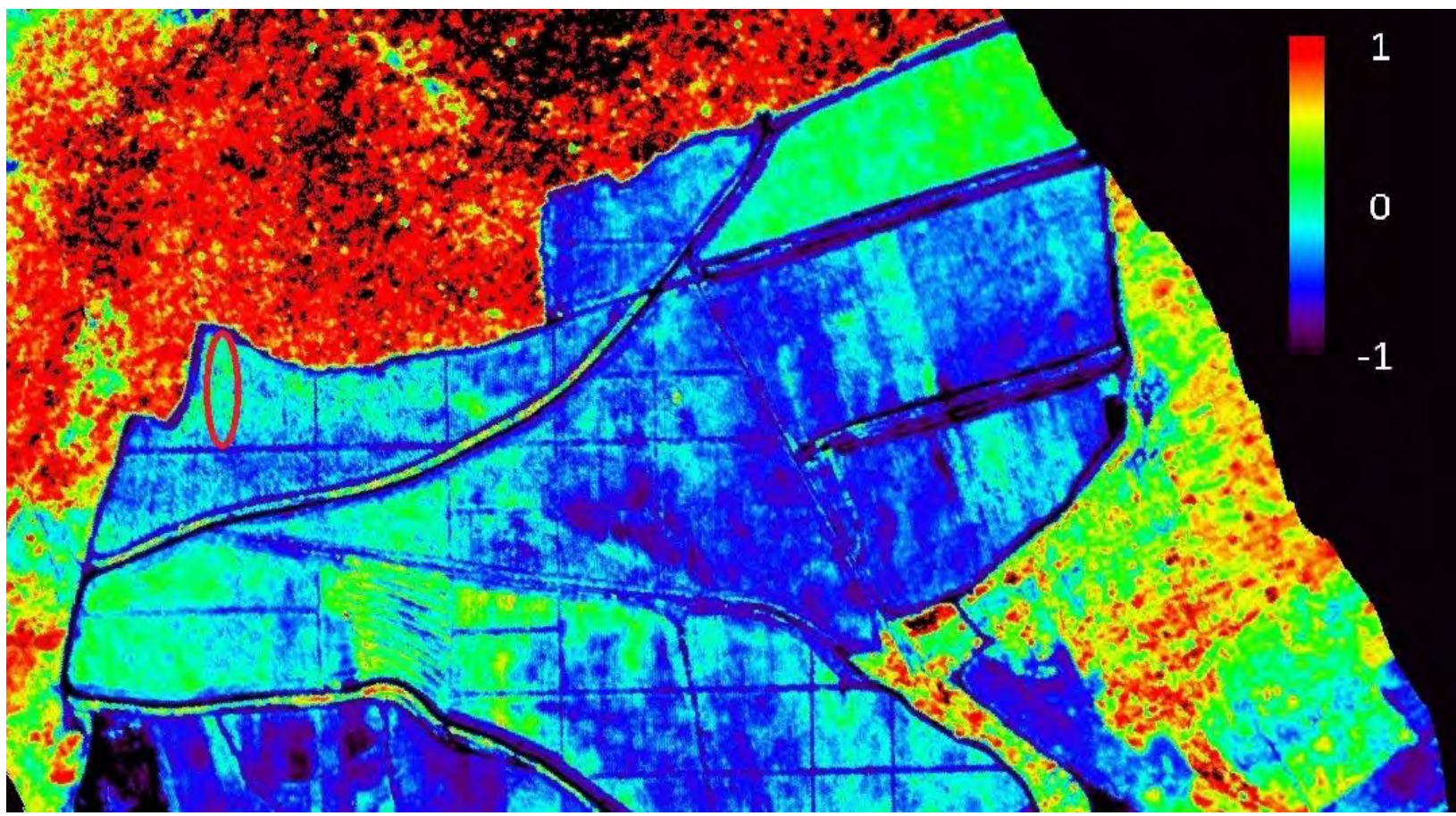

Vegetációs index (NDVI) (Forrás: Károly Róbert Főiskola Távérzékelési és Vidékfejlesztési Kutatóintézete) A piros ellipszis a kísérlet helyét jelöli. 


\section{M3. A kísérlet évjáratainak jellemzése}

Az egyes évjáratokra jellemző középhőmérsékleteket és csapadékmennyiségeket, havi bontásban, külön-külön mutatom be és összevetem az 50 éves átlaggal. Ezután összegzem az évjáratok legfontosabb paramétereit a tenyészidőszakra, illetve az egész évre vonatkozóan.

\section{A 2011-es évjárat}

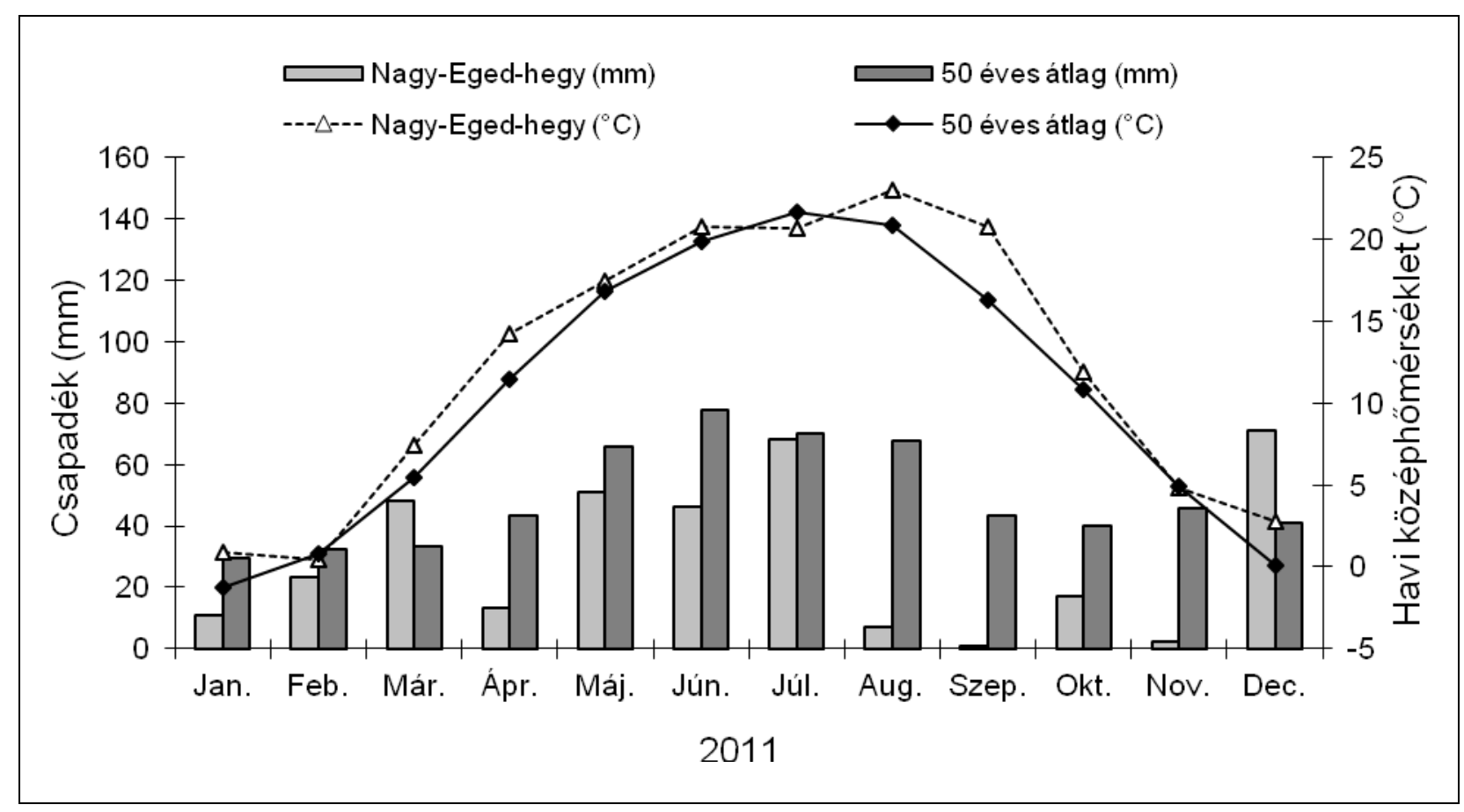

A 2011-es évjárat fontosabb meteorológiai adatai és az 50 éves átlag

A 2010-es extrémen hủvös, már-már özönvízszerủ esővel tarkított évet egy gyökeresen eltérő, de szintén szélsőségekben bővelkedő követte. A 2011-es év rendkívül meleg és száraz volt. A szőlő fejlődése, érése ennek megfelelően egész évben gyorsan, zavartalanul haladt elöre. Láthatóvá válik, hogy a február és július hónapokat leszámítva mindenhol magasabban alakultak a havi középhőmérsékletek, mint az 50 éves átlag. Legmelegebbek a termésérés hónapjai, az augusztus és a szeptember voltak. A csapadék mennyisége az 50 éves átlaghoz viszonyítva, majdnem minden hónapban jóval kevesebb volt. A legszembetünőbb, hogy a legmelegebb hónapokban szinte egyáltalán nem esett eső. Súlyos vízhiány ugyanakkor nem alakult ki, mivel a 2010-es év során hullott nagy mennyiségü csapadék hatására a talaj víztartalékai feltöltődtek. 


\section{A 2012-es évjárat}

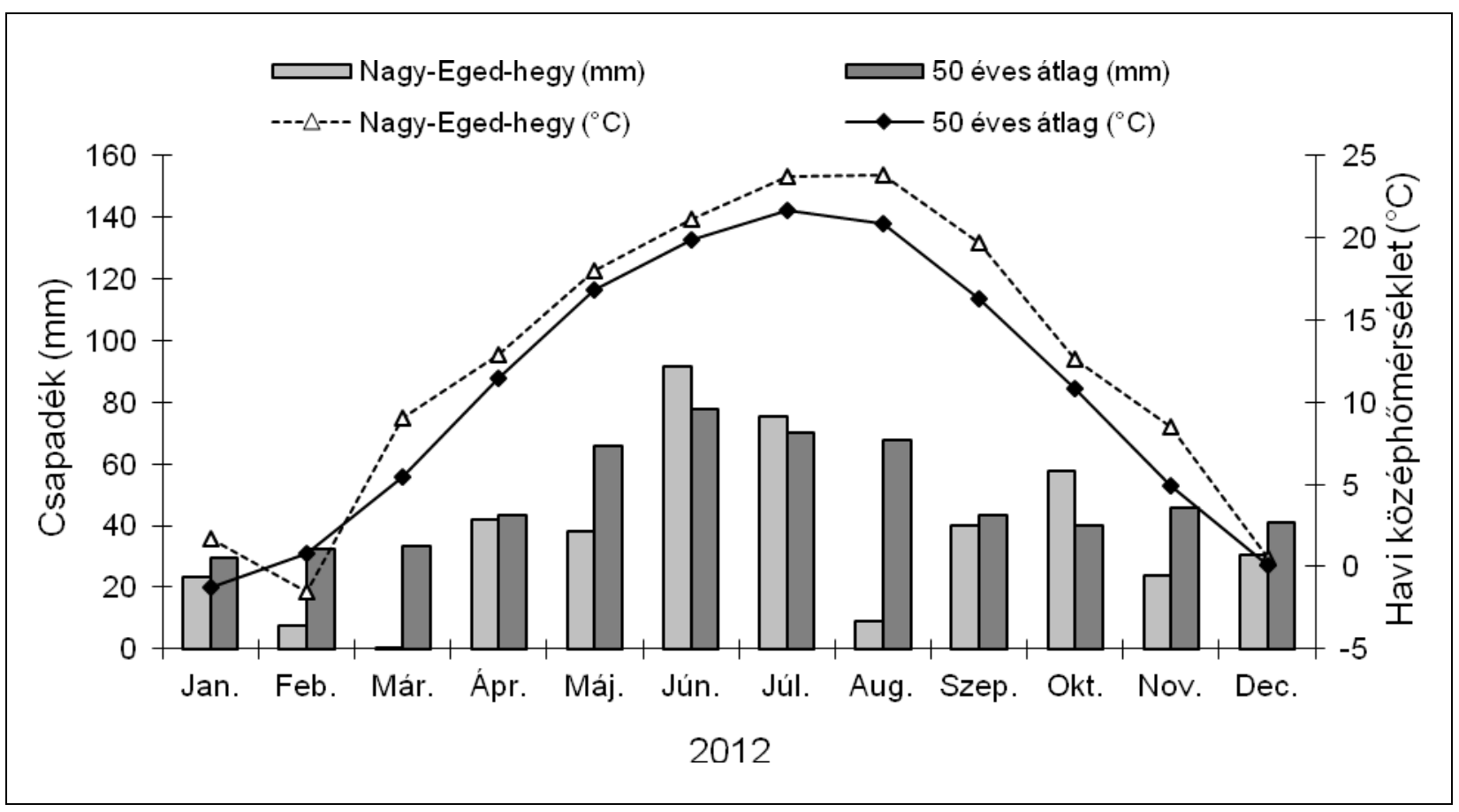

A 2012-es évjárat fontosabb meteorológiai adatai és az 50 éves átlag

Megállapítható, hogy az előzőhöz sokban hasonlító évről van szó. A csapadék mennyisége valamivel több volt ugyan, mint a megelőző évben, de az még így is jócskán elmaradt az 50 éves átlagtól. A havi középhömérsékletek ugyanakkor még a 2011-ben tapasztaltaknál is sokkal magasabb értéket mutattak a szőlő fejlődése szempontjából meghatározó, májustól augusztusig tartó időszakban. A szőlő érése emiatt az átlagnál gyorsabb volt. A magas hőmérséklet miatt a talaj párolgási vesztesége jelentősen megnőtt, hosszabb időre kiterjedő aszályos időszak állt be. A rendkívül száraz viszonyokat tovább súlyosbította az a tény, hogy számottevő eső már 2011. augusztusától nem esett. Összességében kijelenthető, hogy mind a 2011-es, mind 2012-es évjárat kedvezett a magas hö- és melegigényü Syrah érési folyamatainak. 


\section{A 2013-as évjárat}

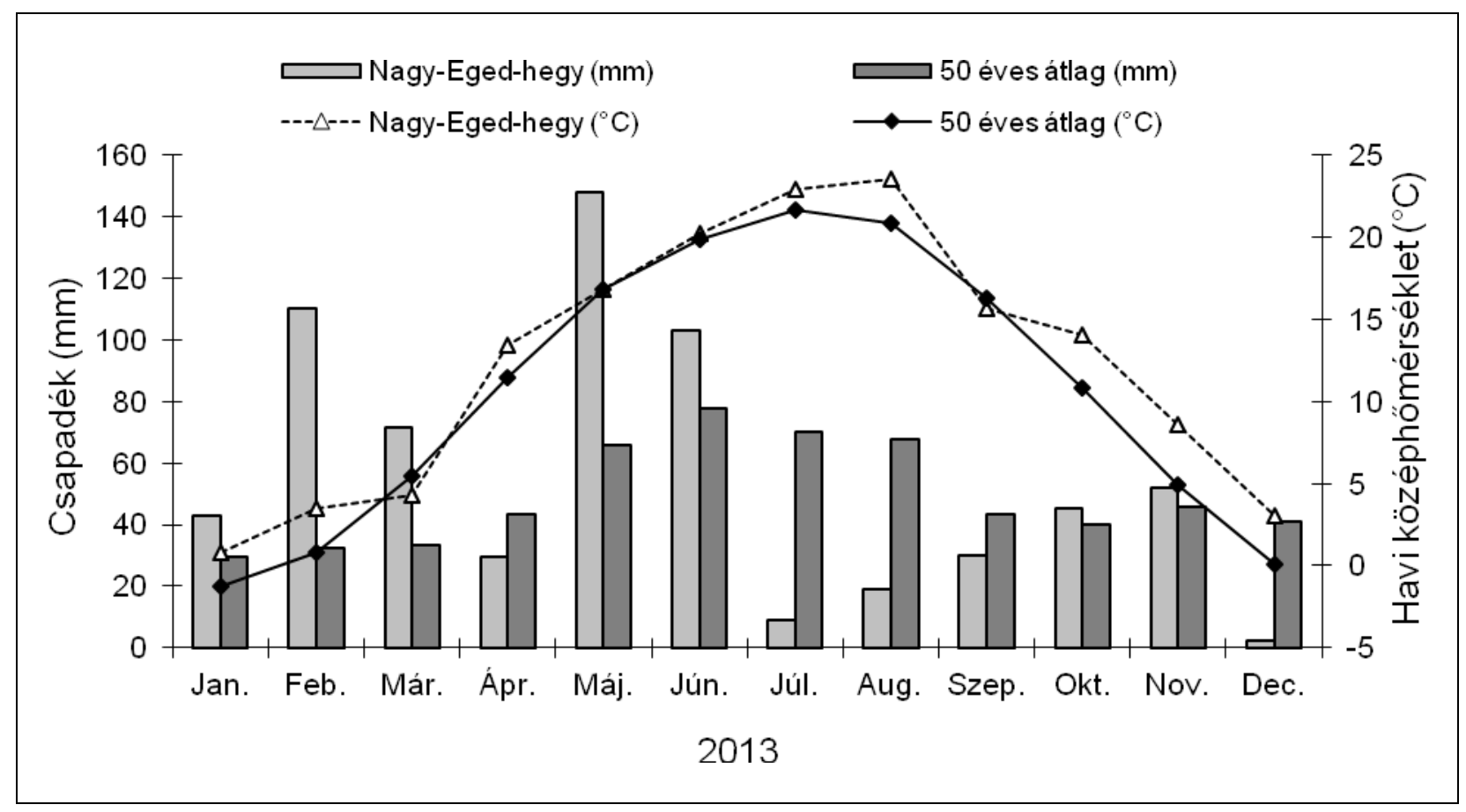

A 2013-as évjárat fontosabb meteorológiai adatai és az 50 éves átlag

A 2013-as évjárat időjárása fordulatot hozott. A csapadék mennyisége, az azt megelőző két évhez viszonyítva jelentősen több volt. A havi középhőmérsékletek alacsonyabban alakultak, de még így is sok esetben meghaladták az 50 éves átlagot. A szeptemberi középhőmérséklet azonban lényegesen alulmúlta a 2011-ben és 2012-ben mért adatokat és enyhén az 50 éves átlagot is. Érdekesség, hogy a téli hónapokat az év elején és végén, egyaránt nagyon enyhe idő jellemezte. A csapadék egyenlőtlen eloszlása szintén szembetűnő. Februárban, márciusban és májusban a szokásos mennyiségnek több mint a kétszerese esett, de a június is igen csapadékosnak bizonyult. A szőlő érése ezek miatt a sajátosságok miatt, vontatottabban, lassabban, haladt.

\section{Az évjáratok összegzése}

A kísérlet szempontjából szerencsés tény, hogy a 2012-es és a 2013-as év számos tekintetben eltérően alakult. Ezekben az években jutattam ki ugyanis LalVigne ${ }^{\circledR}$ Mature lombtrágyát, így lehetőség nyílt arra, hogy a szer hatását, két egymástól eltérő évjáratban is megvizsgálhassam és a kapott eredményekből átfogóbb szakmai következtetéseket vonhassak le. Leegyszerüsítve 2012. egy minden tekintetben jobb, 2013. pedig gyengébb évjáratnak tekinthető a Syrah fajta beérése szempontjából. 
$\mathrm{Az}$ évi és a tenyészidőszakban mért középhőmérsékletek értékei mindhárom év esetében magasabbak voltak, mint az 50 éves átlag. Legmelegebbnek a 2012-es év nevezhető. Ezt a megállapítást a mért minimum és maximum hőmérsékletek is alátámasztják. Ha megvizsgáljuk a csapadékmennyiségeket, kijelenthető, hogy 2011 volt a legszárazabb év. 2012-ben valamivel több eső esett, de az értékek még így is elmaradtak az 50 éves átlagtól. 2013-ban az összes csapadék mennyisége az 50 éves átlaghoz viszonyítva magasabb volt, a tenyészidőben pedig alacsonyabb. 2011. és 2012. esetében egyaránt nagyon magasnak bizonyultak mind az összes, mind a hatásos höösszeg értékei. Külön kiemelendő, hogy a 2012-es évjárat esetében az egész évi hatásos hőösszeg a 2000-es értéket is meghaladta és a tenyészidőszakban is 1800 felett alakult. Ez a magas középhőmérsékletek értékeire vezethető vissza. A napsütéses órák száma mindhárom évjáratban kiemelkedő értékeket ért el.

\begin{tabular}{ccccc}
\hline Tenyészidőszakban & $\mathbf{2 0 1 1}$ & $\mathbf{2 0 1 2}$ & $\mathbf{2 0 1 3}$ & $\mathbf{5 0}$ év átlaga \\
\hline Középhömérséklet $\left({ }^{\circ} \mathrm{C}\right)$ & 19,5 & 19,9 & 18,8 & 17,9 \\
Minimum hőmérséklet $\left({ }^{\circ} \mathrm{C}\right)$ & 15,4 & 15,8 & 15,1 & n.a. \\
Maximum hőmérséklet $\left({ }^{\circ} \mathrm{C}\right)$ & 23,8 & 24,3 & 23,0 & n.a. \\
Csapadék $(\mathrm{mm})$ & 186,4 & 296,0 & 339,1 & 368,1 \\
Teljes hőösszeg $\left({ }^{\circ} \mathrm{C}\right)$ & 3523,6 & 3571,8 & 3359,3 & n.a. \\
Hatásos hőösszeg $\left({ }^{\circ} \mathrm{C}\right)$ & 1763,2 & 1849,7 & 1664,3 & n.a. \\
Napsütéses órák száma & 1519 & 1460 & 1447 & 1396 \\
\hline
\end{tabular}

A fontosabb, évjáratokat jellemző paraméterek alakulása a tenyészidőszakban

\begin{tabular}{ccccc}
\hline Egész évben & $\mathbf{2 0 1 1}$ & $\mathbf{2 0 1 2}$ & $\mathbf{2 0 1 3}$ & $\mathbf{5 0}$ év átlaga \\
\hline Középhőmérséklet $\left({ }^{\circ} \mathrm{C}\right)$ & 12,1 & 12,5 & 12,2 & 10,7 \\
Minimum hömérséklet $\left({ }^{\circ} \mathrm{C}\right)$ & 8,9 & 9,2 & 9,3 & n.a. \\
Maximum hömérséklet $\left({ }^{\circ} \mathrm{C}\right)$ & 15,7 & 16,2 & 15,6 & n.a. \\
Csapadék $(\mathrm{mm})$ & 359,8 & 439,2 & 663,0 & 589,6 \\
Teljes hőösszeg $\left({ }^{\circ} \mathrm{C}\right)$ & 4031,8 & 4174,2 & 3962,8 & n.a. \\
Hatásos höösszeg $\left({ }^{\circ} \mathrm{C}\right)$ & 1902,5 & 2029,1 & 1830,1 & n.a. \\
Napsütéses órák száma & 2339 & 2318 & 2101 & 1975 \\
\hline
\end{tabular}

A fontosabb, évjáratokat jellemző paraméterek alakulása a teljes évben 
A fürtzónában, az érési időszak során mért adatok is jól mutatják az évjáratokra jellemző különbségeket. 2011. esetében az augusztus és szeptember kiemelkedően meleg hőmérsékleteket hozott. Azonban, a három évjárat október havi középhőmérsékleteit vizsgálva, az összességében hűvösebb időjárással jellemezhető 2013-ban mértem a legmagasabb középhőmérsékletet.

\begin{tabular}{cccc}
\hline Tinytag & $\mathbf{2 0 1 1}$ & $\mathbf{2 0 1 2}$ & $\mathbf{2 0 1 3}$ \\
\hline Augusztusi középhömérséklet $\left({ }^{\circ} \mathrm{C}\right)$ & 27,31 & 24,57 & 24,64 \\
Szeptemberi középhömérséklet $\left({ }^{\circ} \mathrm{C}\right)$ & 21,26 & 19,75 & 15,63 \\
Októberi középhömérséklet $\left({ }^{\circ} \mathrm{C}\right)$ & 11,15 & 11,77 & 13,11 \\
\hline
\end{tabular}

A fürtzóna havi középhőmérséklete az érés hónapjaiban 
M4. A must alapanalitikája és az átlagos bogyótömeg $(2012,2013)$

\begin{tabular}{|c|c|c|c|c|c|}
\hline \multirow[t]{4}{*}{ Paraméter } & \multirow[t]{4}{*}{ Évjárat } & \multicolumn{4}{|c|}{ Szüreti időpont } \\
\hline & & \multicolumn{2}{|c|}{ 2012.08.23. / 2013.08.29. } & \multicolumn{2}{|c|}{ 2012.08.30./ 2013.09.05. } \\
\hline & & \multicolumn{4}{|c|}{ Kezelés } \\
\hline & & $\mathrm{C}$ & LM & $\mathrm{C}$ & LM \\
\hline Redukáló cukor & 2012 & $201,0 \pm 2,0 \mathrm{a}$ & $203,3 \pm 2,1 \mathrm{a}$ & $242,0 \pm 3,6 \mathrm{a}$ & $234,0 \pm 2,6 \mathrm{~b}$ \\
\hline$(g / 1)$ & 2013 & $154,3 \pm 4,0 \mathrm{a}$ & $175,0 \pm 3,0 b$ & $180,0 \pm 2,0 \mathrm{a}$ & $191,3 \pm 1,2 b$ \\
\hline Évjárathatás & & $*$ & $*$ & $*$ & $*$ \\
\hline Titrálható & 2012 & $12,73 \pm 0,06 a$ & $13,37 \pm 0,06 b$ & $9,20 \pm 0,00 \mathrm{a}$ & $9,03 \pm 0,06 b$ \\
\hline savtartalom $(g / l)$ & 2013 & $12,30 \pm 0,06 \mathrm{a}$ & $10,60 \pm 0,21 b$ & $11,40 \pm 0,15 \mathrm{a}$ & $10,30 \pm 0,15 b$ \\
\hline Évjárathatás & & $*$ & $*$ & $*$ & $*$ \\
\hline$n \mathrm{H}$ & 2012 & $2,95 \pm 0,01 \mathrm{a}$ & $2,89 \pm 0,01 b$ & $3,10 \pm 0,00 \mathrm{a}$ & $3,14 \pm 0,01 b$ \\
\hline pп & 2013 & $2,80 \pm 0,01 \mathrm{a}$ & $2,94 \pm 0,01 b$ & $2,85 \pm 0,01 \mathrm{a}$ & $2,98 \pm 0,01 b$ \\
\hline Évjárathatás & & $*$ & $*$ & $*$ & $*$ \\
\hline Átlagos & 2012 & $1,37 \pm 0,03 a$ & $1,38 \pm 0,01 \mathrm{a}$ & $1,42 \pm 0,03 \mathrm{a}$ & $1,36 \pm 0,02 b$ \\
\hline bogyótömeg (g) & 2013 & $1,51 \pm 0,05 \mathrm{a}$ & $1,52 \pm 0,04 a$ & $1,67 \pm 0,02 \mathrm{a}$ & $1,69 \pm 0,03 a$ \\
\hline Évjárathatás & & $*$ & $*$ & $*$ & $*$ \\
\hline
\end{tabular}

A különböző latin betükkel jelölt értékek, a kezelések közötti szignifikáns különbséget jelölik azonos évben és azonos szüreti időpontban. A * az évjáratok között szignifikáns különbséget jelöli, azonos kezelésen és szüreti időponton belül. Az összehasonlításokat $p=0,05$ szinten végeztük. Minden érték az átlagot \pm a szórást jelenti. $n=3$, kivéve az átlagos bogyótömeget, ahol $\mathrm{n}=100$ 
DOI: $10.14267 /$ phd.2015023

\begin{tabular}{|c|c|c|c|c|c|c|c|}
\hline \multirow[t]{4}{*}{ Paraméter } & \multirow[t]{4}{*}{ Évjárat } & \multicolumn{6}{|c|}{ Szüreti időpont } \\
\hline & & \multicolumn{2}{|c|}{ 2012.09.06. / 2013.09.12. } & \multicolumn{2}{|c|}{ 2012.09.13./ 2013.09.19. } & \multicolumn{2}{|c|}{ 2012.09.27. / 2013.10.03. } \\
\hline & & \multicolumn{6}{|c|}{ Kezelés } \\
\hline & & $\mathrm{C}$ & LM & $\mathrm{C}$ & LM & $\mathrm{C}$ & LM \\
\hline Redukáló cukor & 2012 & $250,7 \pm 3,1 \mathrm{a}$ & $259,7 \pm 1,2 b$ & $260,0 \pm 1,0 \mathrm{a}$ & $264,3 \pm 2,1 b$ & $267,7 \pm 1,2 \mathrm{a}$ & $267,3 \pm 0,6 \mathrm{a}$ \\
\hline$(g / 1)$ & 2013 & $198,7 \pm 1,5 \mathrm{a}$ & $196,0 \pm 1,0 \mathrm{a}$ & $204,3 \pm 3,1 \mathrm{a}$ & $221,7 \pm 2,1 b$ & $231,0 \pm 2,6 \mathrm{a}$ & $228,7 \pm 2,1 \mathrm{a}$ \\
\hline Évjárathatás & & $*$ & $*$ & $*$ & $*$ & $*$ & $*$ \\
\hline Titrálható & 2012 & $7,6 \pm 0,1 \mathrm{a}$ & $6,3 \pm 0,0 b$ & $5,1 \pm 0,1 \mathrm{a}$ & $5,3 \pm 0,1 b$ & $5,5 \pm 0,1 \mathrm{a}$ & $5,9 \pm 0,0 \mathrm{~b}$ \\
\hline savtartalom $(\mathrm{g} / \mathrm{l})$ & 2013 & $10,8 \pm 0,1 \mathrm{a}$ & $9,4 \pm 0,1 b$ & $10,2 \pm 0,1 \mathrm{a}$ & $8,9 \pm 0,1 b$ & $8,6 \pm 0,1 \mathrm{a}$ & $9,2 \pm 0,1 b$ \\
\hline Évjárathatás & & $*$ & $*$ & $*$ & $*$ & $*$ & $*$ \\
\hline $\mathrm{nH}$ & 2012 & $3,14 \pm 0,02 \mathrm{a}$ & $3,23 \pm 0,00 \mathrm{~b}$ & $3,32 \pm 0,01 \mathrm{a}$ & $3,34 \pm 0,01 b$ & $3,25 \pm 0,01 \mathrm{a}$ & $3,34 \pm 0,01 b$ \\
\hline $\mathrm{pH}$ & 2013 & $2,90 \pm 0,01 \mathrm{a}$ & $2,89 \pm 0,00 \mathrm{a}$ & $2,93 \pm 0,01 \mathrm{a}$ & $3,02 \pm 0,02 b$ & $2,94 \pm 0,01 \mathrm{a}$ & $2,91 \pm 0,01 b$ \\
\hline Évjárathatás & & $*$ & $*$ & $*$ & $*$ & $*$ & $*$ \\
\hline Átlagos & 2012 & $1,28 \pm 0,01 \mathrm{a}$ & $1,35 \pm 0,02 b$ & $1,25 \pm 0,03 a$ & $1,22 \pm 0,01 \mathrm{a}$ & $1,35 \pm 0,03 a$ & $1,37 \pm 0,03 \mathrm{a}$ \\
\hline bogyótömeg (g) & 2013 & $1,74 \pm 0,03 \mathrm{a}$ & $1,79 \pm 0,05 \mathrm{a}$ & $1,71 \pm 0,07 \mathrm{a}$ & $1,76 \pm 0,06 \mathrm{a}$ & $1,47 \pm 0,05 \mathrm{a}$ & $1,48 \pm 0,06 \mathrm{a}$ \\
\hline Évjárathatás & & $*$ & $*$ & $*$ & $*$ & $*$ & * \\
\hline
\end{tabular}

A különböző latin betükkel jelölt értékek, a kezelések közötti szignifikáns különbséget jelölik azonos évben és azonos szüreti időpontban. A * az évjáratok között szignifikáns különbséget jelöli, azonos kezelésen és szüreti időponton belül. Az összehasonlításokat $p=0,05$ szinten végeztük. Minden érték az átlagot \pm a szórást jelenti. $n=3$, kivéve az átlagos bogyótömeget, ahol $n=100$ 
DOI: $10.14267 /$ phd.2015023

M5. A fenolos érettség alakulása $(2012,2013)$

\begin{tabular}{|c|c|c|c|c|c|}
\hline \multirow[t]{2}{*}{ Paraméter } & \multirow[t]{2}{*}{ Évjárat } & \multicolumn{4}{|c|}{ Szüreti időpont } \\
\hline & & \multicolumn{2}{|c|}{ 2012.08.23. / 2013.08.29. } & \multicolumn{2}{|c|}{ 2012.08.30./ 2013.09.05 } \\
\hline & & \multicolumn{4}{|c|}{ Kezelés } \\
\hline & & $\mathrm{C}$ & LM & $\mathrm{C}$ & LM \\
\hline Összes antocianin & 2012 & $1336 \pm 121 \mathrm{a}$ & $1443 \pm 131 \mathrm{a}$ & $1611 \pm 102 \mathrm{a}$ & $1635 \pm 123 a$ \\
\hline (A1) (mg/l) & 2013 & $808 \pm 38 a$ & $1090 \pm 18 b$ & $1088 \pm 68 \mathrm{a}$ & $1138 \pm 60 \mathrm{a}$ \\
\hline Évjárathatás & & $*$ & $*$ & $*$ & $*$ \\
\hline Összes kivonható antocianin & 2012 & $651 \pm 13 a$ & $709 \pm 30 b$ & $843 \pm 14 a$ & $896 \pm 29 b$ \\
\hline$(\mathrm{A} 3.4)(\mathrm{mg} / \mathrm{l})$ & 2013 & $508 \pm 27 a$ & $665 \pm 30 b$ & $529 \pm 23 a$ & $684 \pm 17 b$ \\
\hline Évjárathatás & & $*$ & & $*$ & * \\
\hline 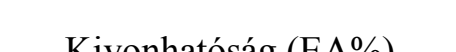 & 2012 & $51,0 \pm 3,5 \mathrm{a}$ & $50,6 \pm 5,2 \mathrm{a}$ & $47,6 \pm 2,5 \mathrm{a}$ & $45,1 \pm 2,3 \mathrm{a}$ \\
\hline Nivominatusag (LA\%o) & 2013 & $37,1 \pm 3,3 \mathrm{a}$ & $38,91 \pm 3,1 \mathrm{a}$ & $51,2 \pm 5,1 \mathrm{a}$ & $39,8 \pm 2,9 b$ \\
\hline Évjárathatás & & $*$ & $*$ & & \\
\hline Maóérettséo (SM\%) & 2012 & $47,2 \pm 0,8 \mathrm{a}$ & $66,4 \pm 3,9 b$ & $51,7 \pm 2,4 \mathrm{a}$ & $56,1 \pm 0,2 b$ \\
\hline & 2013 & $71,9 \pm 8,3 \mathrm{a}$ & $69,4 \pm 4,8 \mathrm{a}$ & $66,8 \pm 3,7 \mathrm{a}$ & $65,0 \pm 2,8 \mathrm{a}$ \\
\hline Évjárathatás & & * & & * & * \\
\hline
\end{tabular}

A különböző latin betükkel jelölt értékek, a kezelések közötti szignifikáns különbséget jelölik azonos évben és azonos szüreti időpontban. A * az évjáratok között szignifikáns különbséget jelöli, azonos kezelésen és szüreti időponton belül. Az összehasonlításokat $p=0,05$ szinten végeztük. Minden érték az átlagot \pm a szórást jelenti. $n=3$ 
DOI: $10.14267 /$ phd.2015023

\begin{tabular}{|c|c|c|c|c|c|c|c|}
\hline \multirow[t]{4}{*}{ Paraméter } & \multirow[t]{4}{*}{ Évjárat } & \multicolumn{6}{|c|}{ Szüreti időpont } \\
\hline & & \multicolumn{2}{|c|}{ 2012.09.06. / 2013.09.12. } & \multirow{2}{*}{\multicolumn{2}{|c|}{$\frac{2012.09 .13 . / 2013.09 .19}{\text { Kezelés }}$}} & \multicolumn{2}{|c|}{ 2012.09.27./2013.10.03 } \\
\hline & & & & & & & \\
\hline & & $\mathrm{C}$ & LM & $\mathrm{C}$ & LM & $\mathrm{C}$ & LM \\
\hline \multirow{3}{*}{$\begin{array}{c}\text { Összes antocianin } \\
\text { (A1) (mg/l) } \\
\text { Évjárathatás }\end{array}$} & 2012 & $1754 \pm 41 \mathrm{a}$ & $1781 \pm 82 \mathrm{a}$ & $1781 \pm 48 \mathrm{a}$ & $1888 \pm 34 b$ & $1834 \pm 124 a$ & $1736 \pm 112 \mathrm{a}$ \\
\hline & 2013 & $1084 \pm 61 a$ & $1273 \pm 68 b$ & $1038 \pm 58 \mathrm{a}$ & $1386 \pm 49 b$ & $1356 \pm 57 a$ & $1433 \pm 46 a$ \\
\hline & & $*$ & $*$ & $*$ & $*$ & $*$ & $*$ \\
\hline \multirow{2}{*}{$\begin{array}{l}\text { Összes kivonható antocianin } \\
(\mathrm{A} 3.4)(\mathrm{mg} / \mathrm{l})\end{array}$} & 2012 & $828 \pm 79 a$ & $958 \pm 26 b$ & $801 \pm 84 a$ & $839 \pm 26 a$ & $725 \pm 49 \mathrm{a}$ & $792 \pm 16 b$ \\
\hline & 2013 & $559 \pm 37 \mathrm{a}$ & $702 \pm 40 \mathrm{~b}$ & $593 \pm 22 a$ & $734 \pm 47 b$ & $602 \pm 28 \mathrm{a}$ & $761 \pm 29 b$ \\
\hline Évjárathatás & & $*$ & $*$ & $*$ & $*$ & $*$ & \\
\hline \multirow{2}{*}{ Kivonhatóság (EA\%) } & 2012 & $52,9 \pm 3,4 a$ & $46,1 \pm 3,8 b$ & $54,9 \pm 5,8 \mathrm{a}$ & $55,5 \pm 1,7 \mathrm{a}$ & $60,4 \pm 3,2 \mathrm{a}$ & $54,2 \pm 2,9 a$ \\
\hline & 2013 & $48,2 \pm 6,4 \mathrm{a}$ & $44,7 \pm 5,6 \mathrm{a}$ & $42,6 \pm 5,1 \mathrm{a}$ & $46,9 \pm 4,8 \mathrm{a}$ & $55,6 \pm 1,5 \mathrm{a}$ & $46,9 \pm 1,4 b$ \\
\hline Évjárathatás & & & & & $*$ & & $*$ \\
\hline \multirow{2}{*}{ Magérettség (SM\%) } & 2012 & $58,3 \pm 2,7 \mathrm{a}$ & $55,8 \pm 2,5 \mathrm{a}$ & $55,8 \pm 9,1 \mathrm{a}$ & $65,4 \pm 1,0 \mathrm{a}$ & $66,5 \pm 5,8 \mathrm{a}$ & $56,2 \pm 8,7 \mathrm{a}$ \\
\hline & 2013 & $69,5 \pm 3,5 \mathrm{a}$ & $65,5 \pm 3,8 \mathrm{a}$ & $57,5 \pm 10,6 \mathrm{a}$ & $67,3 \pm 2,0 \mathrm{a}$ & $49,0 \pm 14,2 \mathrm{a}$ & $56,1 \pm 14,0 \mathrm{a}$ \\
\hline
\end{tabular}

A különböző latin betükkel jelölt értékek, a kezelések közötti szignifikáns különbséget jelölik azonos évben és azonos szüreti időpontban. A * az évjáratok között szignifikáns különbséget jelöli, azonos kezelésen és szüreti időponton belül. Az összehasonlításokat p=0,05 szinten végeztük. Minden érték az átlagot \pm a szórást jelenti. $\mathrm{n}=3$ 
DOI: $10.14267 /$ phd.2015023

M6. A héjkeménység, a bogyókeménység és a héjvastagság alakulása $(2012,2013)$

\begin{tabular}{crrrrr}
\hline Paraméter & Évjárat & \multicolumn{4}{c}{ Szüreti időpont } \\
\hline & & $2012.08 .23 . / 2013.08 .29$. & $2012.08 .30 . / 2013.09 .05$. \\
\hline & & \multicolumn{4}{c}{ Kezelés } \\
\hline $\mathrm{F}_{\text {sk }}(\mathrm{N})$ & 2012 & $0,476 \pm 0,080 \mathrm{a}$ & $0,470 \pm 0,084 \mathrm{a}$ & $0,460 \pm 0,072 \mathrm{a}$ & $0,450 \pm 0,069 \mathrm{a}$ \\
Évjárathatás & 2013 & $0,514 \pm 0,112 \mathrm{a}$ & $0,470 \pm 0,096 \mathrm{~b}$ & $0,481 \pm 0,093 \mathrm{a}$ & $0,435 \pm 0,093 \mathrm{~b}$ \\
$\mathrm{E}_{\text {sk }}(\mathrm{N} / \mathrm{mm})$ & 2012 & $0,560 \pm 0,151 \mathrm{a}$ & $0,543 \pm 0,189 \mathrm{a}$ & $0,507 \pm 0,144 \mathrm{a}$ & $0,488 \pm 0,094 \mathrm{a}$ \\
Évjárathatás & 2013 & $0,646 \pm 0,081 \mathrm{a}$ & $0,630 \pm 0,104 \mathrm{a}$ & $0,578 \pm 0,11 \mathrm{a}$ & $0,557 \pm 0,086 \mathrm{a}$ \\
& & $*$ & $*$ & $*$ & $*$ \\
$\mathrm{~W}_{\text {sk }}(\mathrm{mJ})$ & 2012 & $0,248 \pm 0,070 \mathrm{a}$ & $0,255 \pm 0,086 \mathrm{a}$ & $0,262 \pm 0,084 \mathrm{a}$ & $0,256 \pm 0,078 \mathrm{a}$ \\
Évjárathatás & 2013 & $0,253 \pm 0,094 \mathrm{a}$ & $0,222 \pm 0,075 \mathrm{a}$ & $0,248 \pm 0,080 \mathrm{a}$ & $0,213 \pm 0,070 \mathrm{~b}$ \\
& & & & & \\
BH (N) & 2012 & $4,170 \pm 1,160 \mathrm{a}$ & $4,530 \pm 1,210 \mathrm{~b}$ & $3,640 \pm 0,690 \mathrm{a}$ & $3,780 \pm 0,740 \mathrm{a}$ \\
Évjárathatás & 2013 & $4,780 \pm 0,650 \mathrm{a}$ & $4,430 \pm 0,900 \mathrm{~b}$ & $4,230 \pm 0,710 \mathrm{a}$ & $4,180 \pm 0,930 \mathrm{a}$ \\
& & $*$ & & $*$ & $*$ \\
Sp $p_{\text {sk }}(\mathrm{mm})$ & 2012 & $0,198 \pm 0,036 \mathrm{a}$ & $0,229 \pm 0,035 \mathrm{~b}$ & $0,194 \pm 0,042 \mathrm{a}$ & $0,225 \pm 0,038 \mathrm{~b}$ \\
Évjárathatás & 2013 & $0,194 \pm 0,032 \mathrm{a}$ & $0,223 \pm 0,036 \mathrm{~b}$ & $0,189 \pm 0,038 \mathrm{a}$ & $0,211 \pm 0,033 \mathrm{~b}$ \\
\hline
\end{tabular}

A különböző latin betükkel jelölt értékek, a kezelések közötti szignifikáns különbséget jelölik azonos évben és azonos szüreti időpontban. A * az évjáratok között szignifikáns különbséget jelöli, azonos kezelésen és szüreti időponton belül. Az összehasonlításokat $p=0,05$ szinten végeztük. Minden érték az átlagot \pm a szórást jelenti. $n=50$ 
DOI: 10.14267/phd.2015023

\begin{tabular}{|c|c|c|c|c|c|c|c|}
\hline \multirow[t]{4}{*}{ Paraméter } & \multirow[t]{4}{*}{ Évjárat } & \multicolumn{6}{|c|}{ Szüreti időpont } \\
\hline & & \multicolumn{2}{|c|}{ 2012.09.06. / 2013.09.12. } & \multicolumn{2}{|c|}{ 2012.09.13. / 2013.09.19. } & \multicolumn{2}{|c|}{ 2012.09.27. / 2013.10.03. } \\
\hline & & \multicolumn{6}{|c|}{ Kezelés } \\
\hline & & $\mathrm{C}$ & LM & $\mathrm{C}$ & LM & $\mathrm{C}$ & LM \\
\hline \multirow{2}{*}{$\mathrm{F}_{\mathrm{sk}}(\mathrm{N})$} & 2012 & $0,472 \pm 0,066 \mathrm{a}$ & $0,433 \pm 0,063 b$ & $0,409 \pm 0,073 a$ & $0,422 \pm 0,087 \mathrm{a}$ & $0,442 \pm 0,077 \mathrm{a}$ & $0,453 \pm 0,102 \mathrm{a}$ \\
\hline & 2013 & $0,450 \pm 0,106 \mathrm{a}$ & $0,434 \pm 0,097 \mathrm{a}$ & $0,469 \pm 0,098 \mathrm{a}$ & $0,414 \pm 0,105 b$ & $0,458 \pm 0,094 \mathrm{a}$ & $0,415 \pm 0,089 \mathrm{~b}$ \\
\hline Évjárathatás & & & & $*$ & & & \\
\hline \multirow{2}{*}{$\mathrm{E}_{\mathrm{sk}}(\mathrm{N} / \mathrm{mm})$} & 2012 & $0,437 \pm 0,111 \mathrm{a}$ & $0,451 \pm 0,107 \mathrm{a}$ & $0,455 \pm 0,091 \mathrm{a}$ & $0,450 \pm 0,128 \mathrm{a}$ & $0,489 \pm 0,076 \mathrm{a}$ & $0,520 \pm 0,148 \mathrm{a}$ \\
\hline & 2013 & $0,559 \pm 0,103 a$ & $0,525 \pm 0,085 a$ & $0,476 \pm 0,077 \mathrm{a}$ & $0,499 \pm 0,077 \mathrm{a}$ & $0,332 \pm 0,042 \mathrm{a}$ & $0,371 \pm 0,061 b$ \\
\hline Évjárathatás & & $*$ & $*$ & & $*$ & $*$ & $*$ \\
\hline \multirow{2}{*}{$\mathrm{W}_{\mathrm{sk}}(\mathrm{mJ})$} & 2012 & $0,270 \pm 0,102 \mathrm{a}$ & $0,260 \pm 0,075 \mathrm{a}$ & $0,232 \pm 0,075 \mathrm{a}$ & $0,252 \pm 0,104 \mathrm{a}$ & $0,244 \pm 0,071 \mathrm{a}$ & $0,247 \pm 0,096 \mathrm{a}$ \\
\hline & 2013 & $0,226 \pm 0,081 \mathrm{a}$ & $0,233 \pm 0,088 \mathrm{a}$ & $0,283 \pm 0,100 \mathrm{a}$ & $0,224 \pm 0,101 b$ & $0,342 \pm 0,102 \mathrm{a}$ & $0,271 \pm 0,082 b$ \\
\hline Évjárathatás & & $*$ & & $*$ & & $*$ & \\
\hline \multirow{2}{*}{$\mathrm{BH}(\mathrm{N})$} & 2012 & $3,271 \pm 0,578 \mathrm{a}$ & $3,552 \pm 0,672 b$ & $3,114 \pm 0,667 \mathrm{a}$ & $3,252 \pm 0,684 \mathrm{a}$ & $3,450 \pm 0,737 \mathrm{a}$ & $3,822 \pm 0,947 \mathrm{~b}$ \\
\hline & 2013 & $3,940 \pm 0,899 a$ & $4,011 \pm 0,873 a$ & $3,751 \pm 0,745 \mathrm{a}$ & $3,183 \pm 0,617 b$ & $3,266 \pm 0,768 \mathrm{a}$ & $3,134 \pm 0,692 \mathrm{a}$ \\
\hline \multicolumn{2}{|l|}{ Évjárathatás } & $*$ & $*$ & $*$ & & $*$ & $*$ \\
\hline \multirow{2}{*}{$\mathrm{Sp}_{\mathrm{sk}}(\mathrm{mm})$} & 2012 & $0,185 \pm 0,038 \mathrm{a}$ & $0,227 \pm 0,042 b$ & $0,197 \pm 0,028 \mathrm{a}$ & $0,220 \pm 0,037 b$ & $0,197 \pm 0,038 \mathrm{a}$ & $0,228 \pm 0,030 \mathrm{~b}$ \\
\hline & 2013 & $0,190 \pm 0,033 \mathrm{a}$ & $0,210 \pm 0,028 b$ & $0,191 \pm 0,030 \mathrm{a}$ & $0,219 \pm 0,030 b$ & $0,190 \pm 0,030 \mathrm{a}$ & $0,223 \pm 0,035 b$ \\
\hline Évjárathatás & & & & & & & \\
\hline
\end{tabular}

A különböző latin betükkel jelölt értékek, a kezelések közötti szignifikáns különbséget jelölik azonos évben és azonos szüreti időpontban. A * az évjáratok között szignifikáns különbséget jelöli, azonos kezelésen és szüreti idöponton belül. Az összehasonlításokat p=0,05 szinten végeztük. Minden érték az átlagot \pm a szórást jelenti. $n=50$ 
DOI: $10.14267 /$ phd.2015023

M7. A bogyókeménységből származtatott egyéb paraméterek és a mag fizikai tulajdonságai $(2012,2013)$

\begin{tabular}{|c|c|c|c|c|c|}
\hline \multirow[t]{2}{*}{ Paraméter } & \multirow[t]{2}{*}{ Évjárat } & \multicolumn{4}{|c|}{ Szüreti időpont } \\
\hline & & \multicolumn{2}{|c|}{ 2012.08.23. / 2013.08.29. } & \multicolumn{2}{|c|}{ 2012.08.30./ 2013.09.05. } \\
\hline & & \multicolumn{4}{|c|}{ Kezelés } \\
\hline & & $\mathrm{C}$ & $\mathrm{LM}$ & $\mathrm{C}$ & $\mathrm{LM}$ \\
\hline \multirow{2}{*}{ BCo (-) } & 2012 & $0,61 \pm 0,08 \mathrm{a}$ & $0,58 \pm 0,08 \mathrm{a}$ & $0,63 \pm 0,07 a$ & $0,62 \pm 0,06 \mathrm{a}$ \\
\hline & 2013 & $0,58 \pm 0,06 \mathrm{a}$ & $0,61 \pm 0,04 \mathrm{a}$ & $0,62 \pm 0,05 \mathrm{a}$ & $0,60 \pm 0,06 \mathrm{a}$ \\
\hline \multicolumn{6}{|l|}{ Évjárathatás } \\
\hline \multirow{2}{*}{$\mathrm{BG}(\mathrm{N})$} & 2012 & $2,47 \pm 0,51 \mathrm{a}$ & $2,58 \pm 0,50 \mathrm{~b}$ & $2,26 \pm 0,35 a$ & $2,30 \pm 0,33 a$ \\
\hline & 2013 & $2,77 \pm 0,49 \mathrm{a}$ & $2,69 \pm 0,55 \mathrm{a}$ & $2,59 \pm 0,38 \mathrm{a}$ & $2,50 \pm 0,51 \mathrm{a}$ \\
\hline \multicolumn{2}{|l|}{ Évjárathatás } & & & $*$ & \\
\hline \multirow{2}{*}{$\mathrm{BS}(\mathrm{mm})$} & 2012 & $2,66 \pm 0,22 \mathrm{a}$ & $2,62 \pm 0,22 \mathrm{a}$ & $2,77 \pm 0,23 a$ & $2,71 \pm 0,19 a$ \\
\hline & 2013 & $2,78 \pm 0,25 \mathrm{a}$ & $2,97 \pm 0,23 b$ & $2,96 \pm 0,27 \mathrm{a}$ & $2,92 \pm 0,28 \mathrm{a}$ \\
\hline \multicolumn{6}{|l|}{ Évjárathatás } \\
\hline \multirow{2}{*}{$\mathrm{BCh}(\mathrm{mJ})$} & 2012 & $6,57 \pm 1,42 \mathrm{a}$ & $6,74 \pm 1,43 b$ & $6,28 \pm 1,17 \mathrm{a}$ & $6,25 \pm 1,06 a$ \\
\hline & 2013 & $7,74 \pm 1,74 \mathrm{a}$ & $8,04 \pm 1,98 \mathrm{a}$ & $7,68 \pm 1,40 \mathrm{a}$ & $7,38 \pm 2,04 a$ \\
\hline Évjárathatás & & $*$ & $*$ & $*$ & $*$ \\
\hline \multirow{2}{*}{ BR (-) } & 2012 & $0,29 \pm 0,05 a$ & $0,27 \pm 0,04 \mathrm{a}$ & $0,30 \pm 0,05 \mathrm{a}$ & $0,29 \pm 0,04 \mathrm{a}$ \\
\hline & 2013 & $0,28 \pm 0,04 a$ & $0,30 \pm 0,03 \mathrm{a}$ & $0,30 \pm 0,03 \mathrm{a}$ & $0,29 \pm 0,04 \mathrm{a}$ \\
\hline \multicolumn{6}{|l|}{ Évjárathatás } \\
\hline \multirow{2}{*}{$\mathrm{F}_{\mathrm{s}}(\mathrm{N})$} & 2012 & $40,28 \pm 8,05 \mathrm{a}$ & $37,42 \pm 9,07 \mathrm{a}$ & $38,22 \pm 9,84 a$ & $41,27 \pm 8,14 \mathrm{a}$ \\
\hline & 2013 & $31,06 \pm 7,06 \mathrm{a}$ & $29,97 \pm 6,02 \mathrm{a}$ & $30,66 \pm 6,15 \mathrm{a}$ & $29,74 \pm 7,29 a$ \\
\hline \multicolumn{2}{|l|}{ Évjárathatás } & $*$ & $*$ & $*$ & $*$ \\
\hline \multirow{2}{*}{$\mathrm{E}_{\mathrm{s}}(\mathrm{N} / \mathrm{mm})$} & 2012 & $63,93 \pm 11,88 a$ & $66,06 \pm 12,86 a$ & $67,48 \pm 17,41 \mathrm{a}$ & $71,37 \pm 15,49 a$ \\
\hline & 2013 & $70,00 \pm 10,67 a$ & $66,06 \pm 14,18 \mathrm{a}$ & $74,62 \pm 12,17 \mathrm{a}$ & $71,77 \pm 14,52 \mathrm{a}$ \\
\hline Évjárathatás & & $*$ & & $*$ & \\
\hline \multirow{2}{*}{$\mathrm{W}_{\mathrm{s}}(\mathrm{mJ})$} & 2012 & $10,89 \pm 3,93 \mathrm{a}$ & $8,93 \pm 3,04 a$ & $9,66 \pm 3,35 \mathrm{a}$ & $10,57 \pm 2,86 a$ \\
\hline & 2013 & $6,01 \pm 2,24 \mathrm{a}$ & $5,93 \pm 1,99 a$ & $5,63 \pm 1,74 a$ & $5,78 \pm 2,13 a$ \\
\hline Évjárathatás & & $*$ & $*$ & $*$ & $*$ \\
\hline
\end{tabular}

A különbözö latin betükkel jelölt értékek, a kezelések közötti szignifikáns különbséget jelölik azonos évben és azonos szüreti idöpontban. A * az évjáratok között szignifikáns különbséget jelöli, azonos kezelésen és szüreti időponton belül. Az összehasonlításokat $\mathrm{p}=0,05$ szinten végeztük. Minden érték az átlagot \pm a szórást jelenti. $n=50$ 
DOI: $10.14267 /$ phd.2015023

\begin{tabular}{|c|c|c|c|c|c|c|c|}
\hline \multirow[t]{4}{*}{ Paraméter } & \multirow[t]{4}{*}{ Évjárat } & \multicolumn{6}{|c|}{ Szüreti időpont } \\
\hline & & \multicolumn{2}{|c|}{ 2012.09.06. / 2013.09.12. } & \multicolumn{2}{|c|}{ 2012.09.13. / 2013.09.19. } & \multicolumn{2}{|c|}{ 2012.09.27. / 2013.10.03. } \\
\hline & & \multicolumn{6}{|c|}{ Kezelés } \\
\hline & & $\mathrm{C}$ & LM & $\mathrm{C}$ & LM & $\mathrm{C}$ & LM \\
\hline \multirow{2}{*}{$\mathrm{BCo}(-)$} & 2012 & $0,66 \pm 0,06 a$ & $0,62 \pm 0,07 \mathrm{a}$ & $0,63 \pm 0,05 a$ & $0,63 \pm 0,06 a$ & $0,64 \pm 0,05 \mathrm{a}$ & $0,61 \pm 0,05 \mathrm{a}$ \\
\hline & 2013 & $0,58 \pm 0,08 \mathrm{a}$ & $0,64 \pm 0,08 b$ & $0,69 \pm 0,04 \mathrm{a}$ & $0,64 \pm 0,05 b$ & $0,65 \pm 0,05 \mathrm{a}$ & $0,66 \pm 0,06 \mathrm{a}$ \\
\hline Évjárathatás & & * & & & & & \\
\hline \multirow{2}{*}{$\mathrm{BG}(\mathrm{N})$} & 2012 & $2,15 \pm 0,29 a$ & $2,19 \pm 0,40 \mathrm{a}$ & $1,95 \pm 0,37 \mathrm{a}$ & $2,04 \pm 0,38 \mathrm{a}$ & $2,21 \pm 0,44 \mathrm{a}$ & $2,34 \pm 0,56 \mathrm{a}$ \\
\hline & 2013 & $2,27 \pm 0,52 \mathrm{a}$ & $2,58 \pm 0,65 b$ & $2,58 \pm 0,52 \mathrm{a}$ & $2,04 \pm 0,43 b$ & $2,14 \pm 0,50 \mathrm{a}$ & $2,06 \pm 0,44 a$ \\
\hline Évjárathatás & & $*$ & $*$ & $*$ & & & \\
\hline \multirow{2}{*}{ BS (mm) } & 2012 & $2,73 \pm 0,14 \mathrm{a}$ & $2,73 \pm 0,21 \mathrm{a}$ & $2,64 \pm 0,25 \mathrm{a}$ & $2,66 \pm 0,22 \mathrm{a}$ & $2,70 \pm 0,21 \mathrm{a}$ & $2,67 \pm 0,28 b$ \\
\hline & 2013 & $2,76 \pm 0,27 \mathrm{a}$ & $3,17 \pm 0,24 b$ & $3,05 \pm 0,17 \mathrm{a}$ & $2,79 \pm 0,27 b$ & $2,76 \pm 0,30 \mathrm{a}$ & $2,62 \pm 0,29 \mathrm{a}$ \\
\hline Évjárathatás & & & $*$ & $*$ & & & \\
\hline \multirow{2}{*}{$\mathrm{BCh}(\mathrm{mJ})$} & 2012 & $5,89 \pm 0,92 \mathrm{a}$ & $6,03 \pm 1,29 a$ & $5,21 \pm 1,32 \mathrm{a}$ & $5,48 \pm 1,34 a$ & $5,98 \pm 1,42 \mathrm{a}$ & $6,33 \pm 1,90 \mathrm{a}$ \\
\hline & 2013 & $6,30 \pm 1,61 \mathrm{a}$ & $8,27 \pm 2,35 b$ & $7,91 \pm 1,83 \mathrm{a}$ & $5,79 \pm 1,64 b$ & $5,97 \pm 1,70 \mathrm{a}$ & $5,49 \pm 1,63 a$ \\
\hline Évjárathatás & & $*$ & $*$ & $*$ & & & $*$ \\
\hline \multirow{2}{*}{ BR (-) } & 2012 & $0,32 \pm 0,04 a$ & $0,29 \pm 0,05 \mathrm{a}$ & $0,30 \pm 0,04 \mathrm{a}$ & $0,30 \pm 0,04 \mathrm{a}$ & $0,31 \pm 0,04 \mathrm{a}$ & $0,28 \pm 0,04 \mathrm{a}$ \\
\hline & 2013 & $0,27 \pm 0,05 \mathrm{a}$ & $0,32 \pm 0,05 \mathrm{a}$ & $0,35 \pm 0,04 \mathrm{a}$ & $0,31 \pm 0,04 \mathrm{~b}$ & $0,29 \pm 0,03 a$ & $0,28 \pm 0,03 a$ \\
\hline \multicolumn{2}{|l|}{ Évjárathatás } & & $*$ & $*$ & & & \\
\hline \multirow{2}{*}{$\mathrm{F}_{\mathrm{s}}(\mathrm{N})$} & 2012 & $38,50 \pm 8,26 \mathrm{a}$ & $38,88 \pm 9,64 a$ & $38,52 \pm 9,17 \mathrm{a}$ & $37,61 \pm 8,12 \mathrm{a}$ & $37,68 \pm 8,11 \mathrm{a}$ & $39,91 \pm 10,51 \mathrm{a}$ \\
\hline & 2013 & $30,77 \pm 7,13 a$ & $33,85 \pm 5,78 a$ & $35,60 \pm 6,02 \mathrm{a}$ & $34,61 \pm 6,42 \mathrm{a}$ & $33,35 \pm 6,14 a$ & $33,14 \pm 8,11 \mathrm{a}$ \\
\hline \multicolumn{2}{|l|}{ Évjárathatás } & $*$ & $*$ & & $*$ & $*$ & $*$ \\
\hline \multirow{2}{*}{$\mathrm{E}_{\mathrm{s}}(\mathrm{N} / \mathrm{mm})$} & 2012 & $69,66 \pm 14,51 \mathrm{a}$ & $73,46 \pm 11,82 a$ & $68,31 \pm 12,29 a$ & $68,58 \pm 14,79 a$ & $73,94 \pm 15,33 \mathrm{a}$ & $73,12 \pm 15,33 a$ \\
\hline & 2013 & $77,67 \pm 13,75 a$ & $78,64 \pm 12,91 \mathrm{a}$ & $82,55 \pm 15,22 \mathrm{a}$ & $87,36 \pm 13,18 a$ & $82,86 \pm 14,24 a$ & $80,37 \pm 16,54 a$ \\
\hline Évjárathatás & & * & $*$ & $*$ & $*$ & $*$ & * \\
\hline \multirow{2}{*}{$\mathrm{W}_{\mathrm{s}}(\mathrm{mJ})$} & 2012 & $9,73 \pm 2,90 \mathrm{a}$ & $9,77 \pm 3,42 \mathrm{a}$ & $9,92 \pm 3,65 \mathrm{a}$ & $9,56 \pm 3,15 \mathrm{a}$ & $9,48 \pm 3,13 a$ & $10,25 \pm 3,65 \mathrm{a}$ \\
\hline & 2013 & $5,77 \pm 2,24 a$ & $6,85 \pm 1,88 \mathrm{a}$ & $7,13 \pm 2,13 a$ & $6,59 \pm 2,32 \mathrm{a}$ & $6,37 \pm 1,78 \mathrm{a}$ & $6,50 \pm 2,27 \mathrm{a}$ \\
\hline Évjárathatás & & * & * & * & * & * & * \\
\hline
\end{tabular}

A különböző latin betűkkel jelölt értékek, a kezelések közötti szignifikáns különbséget jelölik azonos évben és azonos szüreti időpontban. A * az évjáratok között szignifikáns különbséget jelöli, azonos kezelésen és szüreti időponton belül. Az összehasonlításokat $\mathrm{p}=0,05$ szinten végeztük. Minden érték az átlagot \pm a szórást jelenti. $\mathrm{n}=50$ 
M8. A kísérleti borok analitikai jellemzői $(2012,2013)$

\begin{tabular}{|c|c|c|c|c|c|c|c|}
\hline \multirow[t]{4}{*}{ Paraméter } & \multirow[t]{4}{*}{ Évjárat } & \multicolumn{6}{|c|}{ Szüreti időpont } \\
\hline & & \multirow{2}{*}{\multicolumn{2}{|c|}{ 2012.09.06. / 2013.09.12. }} & \multirow{2}{*}{\multicolumn{2}{|c|}{$\begin{array}{c}2012.09 .13 . / 2013.09 .19 . \\
\text { Kezelés }\end{array}$}} & \multicolumn{2}{|c|}{ 2012.09.27. / 2013.10.03. } \\
\hline & & & & & & & \\
\hline & & $\mathrm{C}$ & LM & $\mathrm{C}$ & LM & $\mathrm{C}$ & LM \\
\hline \multirow{2}{*}{ Alkohol (\%v/v) } & 2012 & $14,58 \pm 0,09 \mathrm{a} \alpha$ & $14,43 \pm 0,20 \mathrm{a} \alpha$ & $15,08 \pm 0,26 \mathrm{a} \alpha \beta$ & $15,15 \pm 0,21 \mathrm{a} \beta$ & $15,35 \pm 0,33 \mathrm{a} \beta$ & $15,55 \pm 0,31 \mathrm{a} \beta$ \\
\hline & 2013 & $11,28 \pm 0,18 \mathrm{a} \alpha$ & $12,11 \pm 0,62 \mathrm{a} \alpha \beta$ & $11,87 \pm 0,06 \mathrm{a} \beta$ & $11,62 \pm 0,23 \mathrm{a} \alpha$ & $13,80 \pm 0,50 \mathrm{a} \gamma$ & $13,12 \pm 0,26 \mathrm{a} \beta$ \\
\hline Évjárathatás & & $*$ & $*$ & $*$ & $*$ & $*$ & $*$ \\
\hline \multirow{2}{*}{$\begin{array}{l}\text { Cukormentes } \\
\text { extrakt }(\mathrm{g} / \mathrm{l})\end{array}$} & 2012 & $27,57 \pm 0,06 a \alpha$ & $26,30 \pm 0,20 \mathrm{a} \alpha$ & $27,73 \pm 0,15 \mathrm{a} \alpha$ & $28,20 \pm 0,10 \mathrm{a} \beta$ & $28,40 \pm 0,50 \mathrm{a} \alpha$ & $28,90 \pm 0,20 \mathrm{a} \beta$ \\
\hline & 2013 & $28,50 \pm 0,00 \mathrm{a} \alpha$ & $27,73 \pm 0,68 \mathrm{a} \alpha$ & $29,03 \pm 2,66 \mathrm{a} \alpha$ & $27,87 \pm 0,12 \mathrm{a} \alpha$ & $31,00 \pm 0,85 \mathrm{a} \beta$ & $30,77 \pm 0,58 \mathrm{a} \beta$ \\
\hline \multicolumn{8}{|l|}{ Évjárathatás } \\
\hline \multirow{2}{*}{ Titrálható sav (g/l) } & 2012 & $7,03 \pm 0,06 \mathrm{a} \alpha$ & $6,00 \pm 0,20 \mathrm{~b} \alpha$ & $5,03 \pm 0,06 \mathrm{a} \beta$ & $5,47 \pm 0,31 \mathrm{a} \alpha$ & $5,87 \pm 0,21 \mathrm{a} \gamma$ & $5,63 \pm 0,06 \mathrm{a} \alpha$ \\
\hline & 2013 & $8,33 \pm 0,15 \mathrm{a} \alpha$ & $7,60 \pm 0,10 \mathrm{~b} \alpha$ & $7,63 \pm 0,12 \mathrm{a} \beta$ & $7,00 \pm 0,17 \mathrm{~b} \beta$ & $6,67 \pm 0,15 \mathrm{a} \gamma$ & $6,97 \pm 0,21 \mathrm{a} \beta$ \\
\hline Évjárathatás & & $*$ & $*$ & $*$ & $*$ & $*$ & $*$ \\
\hline \multirow{2}{*}{$\mathrm{pH}$} & 2012 & $3,33 \pm 0,01 \mathrm{a} \alpha$ & $3,65 \pm 0,05 b \alpha$ & $3,72 \pm 0,04 \mathrm{a} \beta$ & $3,81 \pm 0,07 \mathrm{a} \beta$ & $3,86 \pm 0,04 \mathrm{a} \gamma$ & $3,69 \pm 0,02 b \alpha$ \\
\hline & 2013 & $3,02 \pm 0,03 \mathrm{a} \alpha$ & $3,16 \pm 0,01 \mathrm{~b} \alpha$ & $3,15 \pm 0,02 \mathrm{a} \beta$ & $3,07 \pm 0,01 \mathrm{~b} \beta$ & $3,11 \pm 0,01 \mathrm{a} \beta$ & $3,12 \pm 0,02 \mathrm{a} \gamma$ \\
\hline Évjárathatás & & $*$ & $*$ & $*$ & * & * & * \\
\hline \multirow{2}{*}{ Összes polifenol (mg/l) } & 2012 & $2562 \pm 64 \mathrm{a} \alpha$ & $2708 \pm 83 \mathrm{a} \alpha$ & $2944 \pm 59 \mathrm{a} \beta$ & $2928 \pm 68 \mathrm{a} \beta$ & $2782 \pm 50 \mathrm{a} \gamma$ & $2850 \pm 69 \mathrm{~b} \alpha \beta$ \\
\hline & 2013 & $1045 \pm 47 \mathrm{a} \alpha$ & $1035 \pm 78 \mathrm{a} \alpha$ & $1025 \pm 91 \mathrm{a} \alpha$ & $1117 \pm 61 \mathrm{a} \alpha \beta$ & $1304 \pm 165 \mathrm{a} \alpha$ & $1260 \pm 113 a \beta$ \\
\hline Évjárathatás & & $*$ & $*$ & $*$ & $*$ & $*$ & $*$ \\
\hline \multirow{2}{*}{$\begin{array}{l}\text { Leukoantocianinok } \\
\text { (mg/l) }\end{array}$} & 2012 & $1641 \pm 42 \mathrm{a} \alpha$ & $1582 \pm 105 \mathrm{a} \alpha$ & $1543 \pm 39 \mathrm{a} \alpha \beta$ & $1767 \pm 111 b \alpha$ & $1449 \pm 43 \mathrm{a} \beta$ & $1770 \pm 50 \mathrm{~b} \alpha$ \\
\hline & 2013 & $1137 \pm 103 \mathrm{a} \alpha$ & $1248 \pm 89 \mathrm{a} \alpha$ & $1152 \pm 41 \mathrm{a} \alpha$ & $1386 \pm 168 \mathrm{a} \alpha \beta$ & $1526 \pm 102 \mathrm{a} \beta$ & $1626 \pm 141 \mathrm{a} \beta$ \\
\hline Évjárathatás & & $*$ & $*$ & $*$ & $*$ & & \\
\hline \multirow{2}{*}{ Antocianinok (mg/l) } & 2012 & $740 \pm 19 \mathrm{a} \alpha$ & $793 \pm 31 \mathrm{a} \alpha$ & $736 \pm 23 \mathrm{a} \alpha$ & $796 \pm 13 b \alpha$ & $688 \pm 47 \mathrm{a} \alpha$ & $762 \pm 43 \mathrm{a} \alpha$ \\
\hline & 2013 & $340 \pm 56 \mathrm{a} \alpha$ & $406 \pm 10 \mathrm{a} \alpha$ & $408 \pm 9 \mathrm{a} \alpha$ & $463 \pm 21 \mathrm{~b} \alpha \beta$ & $526 \pm 39 \mathrm{a} \beta$ & $576 \pm 51 \mathrm{a} \beta$ \\
\hline Évjárathatás & & $*$ & $*$ & $*$ & $*$ & $*$ & $*$ \\
\hline \multirow{2}{*}{ Katechin (mg/l) } & 2012 & $1517 \pm 73 \mathrm{a} \alpha$ & $1184 \pm 37 b \alpha$ & $1747 \pm 65 \mathrm{a} \beta$ & $1538 \pm 109 \mathrm{~b} \beta$ & $1371 \pm 48 \mathrm{a} \alpha$ & $1421 \pm 52 \mathrm{a} \beta$ \\
\hline & 2013 & $962 \pm 85 \mathrm{a} \alpha$ & $916 \pm 64 \mathrm{a} \alpha$ & $820 \pm 33 \mathrm{a} \alpha$ & $997 \pm 62 b \alpha$ & $1048 \pm 156 a \alpha$ & $1072 \pm 87 \mathrm{a} \alpha$ \\
\hline Évjárathatás & & $*$ & $*$ & $*$ & $*$ & $*$ & $*$ \\
\hline
\end{tabular}




$\begin{array}{cccccccc}\text { Színintenzitás } & 2012 & 23,43 \pm 0,86 \mathrm{a} \alpha & 23,61 \pm 0,64 \mathrm{a} \alpha \beta & 22,18 \pm 0,48 \mathrm{a} \alpha & 24,04 \pm 0,07 \mathrm{~b} \alpha & 22,82 \pm 0,14 \mathrm{a} \alpha & 24,47 \pm 0,07 \mathrm{~b} \beta \\ \left(\mathrm{A}_{420}+\mathrm{A}_{520}\right) & 2013 & 14,68 \pm 2,33 \mathrm{a} \alpha & 20,49 \pm 0,92 \mathrm{~b} \alpha & 17,70 \pm 0,18 \mathrm{a} \alpha & 20,16 \pm 1,67 \mathrm{a} \alpha & 23,34 \pm 0,88 \mathrm{a} \beta & 25,56 \pm 1,75 \mathrm{a} \beta \\ \text { Évjárathatás } & & * & * & * & * & \\ \text { Színárnyalat } & 2012 & 0,60 \pm 0,02 \mathrm{a} \alpha & 0,64 \pm 0,02 \mathrm{a} \alpha & 0,63 \pm 0,02 \mathrm{a} \alpha \beta & 0,64 \pm 0,01 \mathrm{a} \alpha & 0,65 \pm 0,01 \mathrm{a} \beta & 0,63 \pm 0,00 \mathrm{a} \alpha \\ \left(\mathrm{A}_{420} / \mathrm{A}_{520}\right) & 2013 & 0,39 \pm 0,01 \mathrm{a} \alpha & 0,37 \pm 0,01 \mathrm{~b} \alpha & 0,35 \pm 0,00 \mathrm{a} \beta & 0,34 \pm 0,00 \mathrm{~b} \beta & 0,34 \pm 0,00 \mathrm{a} \beta & 0,34 \pm 0,00 \mathrm{a} \beta \\ \text { Évjárathatás } & & * & * & * & * & * & * \\ \text { Sósav (HCl) index }(\%) & 2012 & 4,83 \pm 0,15 \mathrm{a} \alpha & 5,06 \pm 3,16 \mathrm{a} \alpha & 6,53 \pm 0,35 \mathrm{a} \beta & 12,99 \pm 0,30 \mathrm{~b} \beta & 9,50 \pm 0,36 \mathrm{a} \gamma & 11,16 \pm 1,24 \mathrm{a} \beta \\ \text { Évjárathatás } & 2013 & 5,01 \pm 0,53 \mathrm{a} \alpha & 6,14 \pm 0,54 \mathrm{a} \alpha & 4,97 \pm 0,73 \mathrm{a} \alpha & 4,34 \pm 0,61 \mathrm{a} \beta & 4,43 \pm 0,68 \mathrm{a} \alpha & 6,27 \pm 0,14 \mathrm{~b} \alpha \\ \text { Zselatin index }(\%) & 2012 & 46,91 \pm 1,19 \mathrm{a} \alpha & 51,58 \pm 0,51 \mathrm{~b} \alpha & 52,32 \pm 1,65 \mathrm{a} \beta & 52,50 \pm 0,21 \mathrm{a} \alpha & 52,59 \pm 0,91 \mathrm{a} \beta & 56,58 \pm 0,36 \mathrm{~b} \beta \\ \text { Évjárathatás } & 2013 & 26,40 \pm 2,52 \mathrm{a} \alpha \beta & 23,17 \pm 1,85 \mathrm{a} \alpha \beta & 23,13 \pm 0,93 \mathrm{a} \alpha & 23,23 \pm 0,35 \mathrm{a} \alpha & 18,20 \pm 0,30 \mathrm{a} \beta & 18,90 \pm 0,30 \mathrm{~b} \beta \\ & & * & * & * & * & * & *\end{array}$

A különböző latin betükkel jelölt értékek, a kezelések közötti szignifikáns különbséget jelölik azonos évben és azonos szüreti időpontban. A különböző görög betükkel jelölt értékek, a szüreti idöpontok közötti szignifikáns különbséget jelölik azonos évben és azonos kezelésen belül. A * az évjáratok között szignifikáns különbséget jelöli, azonos kezelésen és szüreti időponton belül. Az összehasonlításokat p=0,05 szinten végeztük. Minden érték az átlagot \pm a szórást jelenti. $n=3$ 
M9. A kísérleti borok sztilbéntartalma $(2012,2013)$

\begin{tabular}{|c|c|c|c|c|c|c|c|}
\hline \multirow[t]{3}{*}{ Paraméter } & \multirow[t]{3}{*}{ Évjárat } & \multicolumn{6}{|c|}{ Szüreti időpont } \\
\hline & & \multicolumn{2}{|c|}{ 2012.09.06. / 2013.09.12. } & \multirow{2}{*}{\multicolumn{2}{|c|}{$\begin{array}{c}\text { 2012.09.13. / 2013.09.19. } \\
\text { Kezelés }\end{array}$}} & \multicolumn{2}{|c|}{ 2012.09.27./ 2013.10.03. } \\
\hline & & & & & & & \\
\hline & & $\mathrm{C}$ & LM & $\mathrm{C}$ & LM & $\mathrm{C}$ & LM \\
\hline Transz-rezveratrol & 2012 & n.d. & $0,09 \pm 0,01 \alpha$ & $0,83 \pm 0,25 \mathrm{a} \alpha$ & $0,41 \pm 0,01 \mathrm{~b} \beta$ & $0,30 \pm 0,10 \mathrm{a} \alpha$ & $0,23 \pm 0,08 \mathrm{a} \alpha \beta$ \\
\hline$(\mathrm{mg} / \mathrm{l})$ & 2013 & n.d. & $0,16 \pm 0,14 \alpha \beta$ & $0,07 \pm 0,12 \alpha$ & n.d. & $0,63 \pm 0,10 \mathrm{a} \beta$ & $0,50 \pm 0,11 \mathrm{a} \beta$ \\
\hline Évjárathatás & & & & $*$ & $*$ & $*$ & $*$ \\
\hline$C$ icz-rezyeratrol $(\mathrm{mo} / 1)$ & 2012 & n.d. & n.d. & n.d. & n.d. & n.d. & n.d. \\
\hline cisz-rezveratror (mg/l) & 2013 & n.d. & n.d. & n.d. & n.d. & n.d. & n.d. \\
\hline Évjárathatás & & & & & & & \\
\hline Transz-niceid $(\mathrm{mo} / 1)$ & 2012 & $1,07 \pm 0,06 \mathrm{a} \alpha$ & $1,39 \pm 0,04 \mathrm{~b} \alpha$ & $0,57 \pm 0,06 \mathrm{a} \beta$ & $1,45 \pm 0,05 \mathrm{~b} \alpha$ & $0,50 \pm 0,05 \mathrm{a} \beta$ & $0,55 \pm 0,05 \mathrm{a} \beta$ \\
\hline & 2013 & $0,37 \pm 0,28 \mathrm{a} \alpha$ & $0,46 \pm 0,16 \mathrm{a} \alpha$ & $0,41 \pm 0,07 \mathrm{a} \alpha$ & $0,12 \pm 0,11 \mathrm{~b} \beta$ & $0,47 \pm 0,32 \mathrm{a} \alpha$ & $0,74 \pm 0,05 \mathrm{a} \alpha$ \\
\hline Évjárathatás & & $*$ & $*$ & $*$ & $*$ & & $*$ \\
\hline Cisz-piceid (mg/l) & 2012 & n.d. & $0,93 \pm 0,15 \alpha \beta$ & $1,20 \pm 0,20 \mathrm{a} \alpha$ & $0,90 \pm 0,00 \mathrm{a} \alpha$ & $0,87 \pm 0,06 \mathrm{a} \alpha$ & $0,61 \pm 0,07 \mathrm{~b} \beta$ \\
\hline Évjárathatás & 2013 & $\begin{array}{c}0,41 \pm 0,09 \mathrm{a} \alpha \\
*\end{array}$ & $0,60 \pm 0,34 \mathrm{a} \alpha$ & $\begin{array}{c}0,25 \pm 0,02 \mathrm{a} \alpha \\
*\end{array}$ & $\begin{array}{c}0,87 \pm 0,19 \mathrm{~b} \alpha \beta \\
*\end{array}$ & $1,05 \pm 0,31 \mathrm{a} \beta$ & $\begin{array}{c}1,63 \pm 0,30 \mathrm{a} \beta \\
*\end{array}$ \\
\hline$\sum(\mathrm{mg} / 1)$ & 2012 & $1,07 \pm 0,06 \mathrm{a} \alpha$ & $2,42 \pm 0,18 \mathrm{~b} \alpha$ & $2,60 \pm 0,00 \mathrm{a} \beta$ & $2,76 \pm 0,06 \mathrm{a} \alpha$ & $1,67 \pm 0,20 \mathrm{a} \gamma$ & $1,39 \pm 0,17 \mathrm{a} \beta$ \\
\hline Évjárathatás & 2013 & $0,78 \pm 0,32 \mathrm{a} \alpha$ & $\begin{array}{c}1,23 \pm 0,26 b \alpha \\
*\end{array}$ & $\begin{array}{c}0,73 \pm 0,11 \mathrm{a} \alpha \\
*\end{array}$ & $\begin{array}{c}0,99 \pm 0,10 \mathrm{a} \alpha \\
*\end{array}$ & $\begin{array}{c}2,14 \pm 0,69 \mathrm{a} \beta \\
*\end{array}$ & $\begin{array}{c}2,87 \pm 0,23 \mathrm{~b} \beta \\
*\end{array}$ \\
\hline
\end{tabular}

A különbözö latin betükkel jelölt értékek, a kezelések közötti szignifikáns különbséget jelölik azonos évben és azonos szüreti időpontban. A különböző görög betükkel jelölt értékek, a szüreti időpontok közötti szignifikáns különbséget jelölik azonos évben és azonos kezelésen belül. A * az évjáratok között szignifikáns különbséget jelöli, azonos kezelésen és szüreti időponton belül. Az összehasonlításokat p=0,05 szinten végeztük. Minden érték az átlagot \pm a szórást jelenti. n.d.= nem detektálható, $n=3$ 
M10. A borok egyes jellemzőire az érzékszervi bírálat során adott pontszámok átlaga és szórása

\begin{tabular}{|c|c|c|c|c|c|c|c|c|c|c|c|c|c|c|}
\hline Évjárat & $\begin{array}{l}\text { Szüreti } \\
\text { időpont }\end{array}$ & & Megjelenés & Illatintenzitás & $\begin{array}{c}\text { Gyümölcsös } \\
\text { jelleg illatban }\end{array}$ & $\begin{array}{l}\text { Füszeres } \\
\text { jelleg } \\
\text { illatban }\end{array}$ & $\begin{array}{l}\text { Gyümölcsös } \\
\text { jelleg ízben }\end{array}$ & $\begin{array}{l}\text { Füszeres } \\
\text { jelleg } \\
\text { ízben }\end{array}$ & Fajtakarakter & Tanninérzet & $\begin{array}{l}\text { Teltségérzet, } \\
\text { testesség }\end{array}$ & Savérzet & $\begin{array}{c}\text { Íz } \\
\text { hosszúság }\end{array}$ & $\begin{array}{l}\text { Összbenyomás, } \\
\text { harmónia }\end{array}$ \\
\hline \multirow{6}{*}{2011} & \multirow{2}{*}{ 2011.09.13. } & Átlag & 9,3 & 7,1 & 6,1 & 7,6 & 6,2 & 6,8 & 7,5 & 6,7 & 6,5 & 6,2 & 6,4 & 6,7 \\
\hline & & Szórás & 0,7 & 1,4 & 1,9 & 1,6 & 1,4 & 1,6 & 1,6 & 1,0 & 1,7 & 1,9 & 2,1 & 1,5 \\
\hline & \multirow{2}{*}{ 2011.09.27. } & Átlag & 9,4 & 7,3 & 6,3 & 6,9 & 6,8 & 6,8 & 7,4 & 7,0 & 6,9 & 5,8 & 6,6 & 6,7 \\
\hline & & Szórás & 0,7 & 1,5 & 2,3 & 1,3 & 1,8 & 1,7 & 1,7 & 1,4 & 1,6 & 1,9 & 2,2 & 1,9 \\
\hline & \multirow{2}{*}{2011.10 .10} & Átlag & 9,6 & 7,9 & 6,8 & 7,2 & 7,3 & 7,8 & 8,3 & 7,3 & 7,9 & 6,3 & 7,6 & 7,8 \\
\hline & & Szórás & 0,6 & 0,9 & 1,7 & 2,3 & 1,2 & 1,3 & 1,3 & 1,4 & 1,6 & 2,1 & 1,9 & 1,2 \\
\hline
\end{tabular}

\begin{tabular}{|c|c|c|c|c|c|c|c|c|c|c|c|c|c|c|c|c|}
\hline Évjárat & $\begin{array}{l}\text { Szüreti } \\
\text { idöpont }\end{array}$ & Kezelés & & Megjelenés & Illatintenzitás & $\begin{array}{l}\text { Gyümölcsös } \\
\text { jelleg illatban }\end{array}$ & $\begin{array}{c}\text { Füszer } \\
\text { es } \\
\text { jelleg } \\
\text { illatba } \\
\text { n }\end{array}$ & $\begin{array}{c}\text { Gyümöl } \\
\text { csös } \\
\text { jelleg } \\
\text { ízben }\end{array}$ & $\begin{array}{l}\text { Füszeres } \\
\text { jelleg ízben }\end{array}$ & $\begin{array}{c}\text { Fajtakarak } \\
\text { ter }\end{array}$ & Savérzet & $\begin{array}{l}\text { Teltségérzet, } \\
\text { testesség }\end{array}$ & $\begin{array}{l}\text { Tanninok } \\
\text { mennyisége }\end{array}$ & Húzósság & Ízhosszúság & $\begin{array}{c}\text { Összbenyo } \\
\text { más, } \\
\text { harmónia }\end{array}$ \\
\hline \multirow{12}{*}{2012} & \multirow{4}{*}{$\begin{array}{c}2012.09 . \\
06 .\end{array}$} & \multirow{2}{*}{ Kontroll (C) } & Átlag & 8,7 & 6,3 & 6,0 & 6,4 & 5,1 & 5,8 & 6,2 & 7,6 & 7,0 & 6,7 & 5,0 & 6,7 & 6,1 \\
\hline & & & Szórás & 1,0 & 0,8 & 0,9 & 0,9 & 1,5 & 1,3 & 1,3 & 1,0 & 0,8 & 0,5 & 1,7 & 1,4 & 0,9 \\
\hline & & \multirow{2}{*}{ Kezelt (LM) } & Átlag & 8,8 & 6,6 & 5,5 & 6,5 & 5,4 & 6,6 & 6,5 & 6,7 & 7,1 & 6,9 & 5,5 & 7,0 & 7,0 \\
\hline & & & Szórás & 0,9 & 0,9 & 1,2 & 1,2 & 1,3 & 1,5 & 1,5 & 1,3 & 0,8 & 0,6 & 1,6 & 1,2 & 0,9 \\
\hline & \multirow{4}{*}{$\begin{array}{c}2012.09 . \\
13 .\end{array}$} & \multirow{2}{*}{ Kontroll (C) } & Átlag & 8,8 & 6,9 & 5,9 & 6,5 & 5,0 & 6,3 & 6,0 & 6,3 & 7,0 & 7,0 & 5,6 & 6,9 & 6,6 \\
\hline & & & Szórás & 1,1 & 1,1 & 1,4 & 1,4 & 1,8 & 1,3 & 1,5 & 1,7 & 1,0 & 1,0 & 1,8 & 1,3 & 1,4 \\
\hline & & \multirow{2}{*}{ Kezelt (LM) } & Átlag & 8,9 & 6,8 & 5,4 & 6,8 & 5,5 & 6,5 & 6,6 & 5,8 & 7,6 & 7,3 & 5,7 & 7,1 & 6,9 \\
\hline & & & Szórás & 1,0 & 1,5 & 1,6 & 1,4 & 1,5 & 1,4 & 1,1 & 1,4 & 1,0 & 1,1 & 2,2 & 1,4 & 1,3 \\
\hline & \multirow{4}{*}{$\begin{array}{c}2012.09 . \\
27 .\end{array}$} & \multirow{2}{*}{ Kontroll (C) } & Átlag & 8,9 & 7,3 & 5,8 & 6,5 & 5,8 & 6,0 & 6,4 & 5,5 & 7,2 & 7,1 & 6,0 & 6,8 & 7,0 \\
\hline & & & Szórás & 1,0 & 1,0 & 1,7 & 1,6 & 1,5 & 1,4 & 1,4 & 1,5 & 1,3 & 1,6 & 1,8 & 1,7 & 1,5 \\
\hline & & \multirow{2}{*}{ Kezelt (LM) } & Átlag & 8,9 & 7,1 & 5,6 & 6,7 & 5,8 & 6,7 & 7,1 & 5,0 & 8,0 & 7,6 & 6,1 & 7,7 & 7,8 \\
\hline & & & Szórás & 1,0 & 1,5 & 1,8 & 2,0 & 1,3 & 1,7 & 1,4 & 1,2 & 0,9 & 1,3 & 2,4 & 1,5 & 1,3 \\
\hline
\end{tabular}


DOI: $10.14267 /$ phd.2015023

\begin{tabular}{|c|c|c|c|c|c|c|c|c|c|c|c|c|c|c|c|c|}
\hline Évjárat & $\begin{array}{l}\text { Szüreti } \\
\text { időpont }\end{array}$ & Kezelés & & Megjelenés & Illatintenzitás & $\begin{array}{c}\text { Gyümölcsös } \\
\text { jelleg illatban }\end{array}$ & $\begin{array}{c}\text { Füszer } \\
\text { es } \\
\text { jelleg } \\
\text { illatba } \\
\text { n }\end{array}$ & $\begin{array}{c}\text { Gyümöl } \\
\text { csös } \\
\text { jelleg } \\
\text { ízben }\end{array}$ & $\begin{array}{l}\text { Füszeres } \\
\text { jelleg ízben }\end{array}$ & $\begin{array}{c}\text { Fajtakarak } \\
\text { ter }\end{array}$ & Savérzet & $\begin{array}{l}\text { Teltségérzet, } \\
\text { testesség }\end{array}$ & $\begin{array}{l}\text { Tanninok } \\
\text { mennyisége }\end{array}$ & Húzósság & Ízhosszúság & $\begin{array}{c}\text { Összbenyo } \\
\text { más, } \\
\text { harmónia }\end{array}$ \\
\hline \multirow{12}{*}{2013} & \multirow{4}{*}{$\begin{array}{c}2013.09 \\
12 .\end{array}$} & \multirow{2}{*}{ Kontroll (C) } & Átlag & 9,4 & 6,2 & 5,1 & 4,8 & 2,6 & 3,1 & 3,5 & 8,5 & 4,3 & 5,0 & 7,3 & 6,2 & 4,3 \\
\hline & & & Szórás & 0,5 & 0,4 & 1,2 & 0,6 & 0,5 & 0,3 & 0,5 & 0,5 & 0,6 & 0,0 & 1,4 & 1,0 & 0,5 \\
\hline & & \multirow{2}{*}{ Kezelt (LM) } & Átlag & 9,4 & 6,6 & 4,5 & 5,4 & 3,5 & 4,1 & 4,3 & 7,0 & 5,3 & 5,5 & 6,6 & 6,7 & 5,7 \\
\hline & & & Szórás & 0,5 & 1,0 & 0,9 & 1,0 & 0,8 & 0,8 & 1,2 & 0,9 & 0,7 & 0,5 & 1,2 & 0,9 & 0,6 \\
\hline & \multirow{4}{*}{$\begin{array}{c}2013.09 \\
19 .\end{array}$} & \multirow{2}{*}{ Kontroll (C) } & Átlag & 9,5 & 6,6 & 4,5 & 5,1 & 4,3 & 4,3 & 4,1 & 7,1 & 5,1 & 5,5 & 6,6 & 6,7 & 5,4 \\
\hline & & & Szórás & 0,5 & 1,1 & 1,1 & 1,1 & 1,0 & 1,4 & 0,8 & 1,4 & 0,9 & 0,5 & 1,5 & 0,9 & 0,7 \\
\hline & & \multirow{2}{*}{ Kezelt (LM) } & Átlag & 9,8 & 6,5 & 4,6 & 5,1 & 4,2 & 4,3 & 4,4 & 7,0 & 5,3 & 5,9 & 6,1 & 6,6 & 5,4 \\
\hline & & & Szórás & 0,4 & 1,1 & 1,4 & 1,3 & 0,7 & 1,1 & 1,0 & 1,2 & 0,7 & 0,8 & 1,0 & 1,2 & 0,9 \\
\hline & \multirow{4}{*}{$\begin{array}{c}2013.10 \\
03 .\end{array}$} & \multirow{2}{*}{ Kontroll (C) } & Átlag & 9,7 & 6,9 & 5,7 & 5,9 & 5,0 & 4,9 & 5,6 & 6,4 & 5,9 & 6,3 & 6,0 & 6,6 & 6,3 \\
\hline & & & Szórás & 0,5 & 1,2 & 1,2 & 1,1 & 0,7 & 1,1 & 0,7 & 1,2 & 0,9 & 0,6 & 1,2 & 1,0 & 1,0 \\
\hline & & \multirow{2}{*}{ Kezelt (LM) } & Átlag & 9,7 & 7,1 & 5,2 & 6,4 & 4,8 & 5,8 & 5,9 & 6,0 & 6,1 & 6,4 & 5,7 & 6,9 & 6,7 \\
\hline & & & Szórás & 0,5 & 1,2 & 1,2 & 1,3 & 1,2 & 1,5 & 1,2 & 1,3 & 0,7 & 0,9 & 1,3 & 1,3 & 1,1 \\
\hline
\end{tabular}

A kísérleti borok egyes érzékszervi jellemzőinek átlagpontszáma és szórása, n=17 
M11. A szüreti időpont hatásának statisztikai kiértékelése

Cukor $\mathrm{EV}=\mathbf{2 0 1 2 , 0 0 K E Z = C}$

\begin{tabular}{|cc|c|c|c|c|c|c|}
\hline \multirow{2}{*}{ zsplusz } & & \multirow{2}{*}{$\mathrm{N}$} & \multicolumn{5}{|c|}{ Subset } \\
\cline { 4 - 8 } & 2,00 & 3 & 201,0000 & & & & \\
\hline & 3,00 & 3 & & 242,0000 & & & \\
Tukey & 4,00 & 3 & & & 250,6667 & & \\
HSD $^{\mathrm{a}, \mathrm{b}, \mathrm{c}}$ & 5,00 & 3 & & & & 260,0000 & \\
& 7,00 & 3 & & & & & 267,6667 \\
& Sig. & & 1,000 & 1,000 & 1,000 & 1,000 & 1,000 \\
\hline
\end{tabular}

Cukor EV=2013,00KEZ $=\mathrm{C}$

\begin{tabular}{|cc|c|c|c|c|c|}
\hline \multirow{2}{*}{ zsplusz } & & \multirow{2}{*}{$\mathrm{N}$} & \multicolumn{5}{|c|}{ Subset } \\
\cline { 4 - 7 } & & & 1 & 2 & 3 & 4 \\
\hline & 2,00 & 3 & 154,3333 & & & \\
Tukey & 4,00 & 3 & & 180,0000 & & \\
HSD $^{\mathrm{a}, \mathrm{b}, \mathrm{c}}$ & 5,00 & 3 & & & 198,6667 & \\
& 7,00 & 3 & & & 204,3333 & \\
& Sig. & & 1,000 & 1,000 &, 170 & 1,000 \\
\hline
\end{tabular}

Cukor EV=2012,00KEZ $=\mathrm{LM}$

\begin{tabular}{|cc|c|c|c|c|c|}
\hline \multirow{2}{*}{ zsplusz } & & \multirow{2}{*}{$\mathrm{N}$} & \multicolumn{5}{|c|}{ Subset } \\
\cline { 4 - 7 } & & & 1 & 2 & 3 & 4 \\
\hline & 2,00 & 3 & 203,3333 & & & \\
Tukey & 4,00 & 3 & & 234,0000 & & \\
HSD $^{\text {a,b,c }}$ & 5,00 & 3 & & & 259,6667 & \\
& 7,00 & 3 & & & 264,3333 & 264,3333 \\
& Sig. & & 1,000 & 1,000 &, 070 &, 343 \\
\hline
\end{tabular}

Cukor EV=2013,00KEZ $=$ LM

\begin{tabular}{|cc|c|c|c|c|c|}
\hline \multirow{2}{*}{ zsplusz } & \multirow{2}{*}{$\mathrm{N}$} & \multicolumn{5}{|c|}{ Subset } \\
\cline { 4 - 7 } & 2,00 & 3 & 175,0000 & & & \\
\hline & 3,00 & 3 & & 191,3333 & & \\
Tukey & 4,00 & 3 & & 196,0000 & & \\
HSD $^{\text {a,b,c }}$ & 5,00 & 3 & & & 221,6667 & \\
& 7,00 & 3 & & & & 228,6667 \\
& Sig. & & 1,000 &, 098 & 1,000 & 1,000 \\
\hline
\end{tabular}


Sav EV $=2012,00 K E Z=C$

\begin{tabular}{|cc|c|c|c|c|c|c|}
\hline \multirow{2}{*}{ zsplusz } & \multirow{2}{*}{$\mathrm{N}$} & \multicolumn{5}{|c|}{ Subset } \\
\cline { 4 - 8 } & 5,00 & 3 & 5,1333 & & & & \\
\hline & 7,00 & 3 & & 5,4667 & & & \\
Tukey & 4,00 & 3 & & & 7,6000 & & \\
HSD $^{\text {a,b,c }}$ & 3,00 & 3 & & & & 9,2000 & \\
& 2,00 & 3 & & & & & 12,7333 \\
& Sig. & & 1,000 & 1,000 & 1,000 & 1,000 & 1,000 \\
\hline
\end{tabular}

Sav $E V=2013,00 K E Z=C$

\begin{tabular}{|cc|c|c|c|c|c|c|}
\hline \multirow{2}{*}{ zsplusz } & & \multirow{2}{*}{$\mathrm{N}$} & \multicolumn{5}{|c|}{ Subset } \\
\cline { 4 - 8 } & 7,00 & 3 & 8,5667 & & & & \\
\hline & 5,00 & 3 & & 10,2000 & & & \\
Tukey & 4,00 & 3 & & & 10,8333 & & \\
HSD $^{\mathrm{a}, \mathrm{b}, \mathrm{c}}$ & 3,00 & 3 & & & & 11,3667 & \\
& 2,00 & 3 & & & & & 12,2667 \\
& Sig. & & 1,000 & 1,000 & 1,000 & 1,000 & 1,000 \\
\hline
\end{tabular}

Sav EV=2012,00KEZ $=$ LM

\begin{tabular}{|cc|c|c|c|c|c|c|}
\hline \multirow{2}{*}{ zsplusz } & \multirow{2}{*}{$\mathrm{N}$} & \multicolumn{5}{|c|}{ Subset } \\
\cline { 4 - 8 } & & & 1 & 2 & 3 & 4 & 5 \\
\hline & 5,00 & 3 & 5,3333 & & & & \\
& 7,00 & 3 & & 5,9000 & & & \\
$\mathbf{G H}$ & 4,00 & 3 & & & 6,3000 & & \\
& 3,00 & 3 & & & & 9,0333 & \\
& 2,00 & 3 & & & & & 13,3667 \\
& Sig. & & 1,000 & 1,000 & 1,000 & 1,000 & 1,000 \\
\hline
\end{tabular}

Sav EV $=2013,00 K E Z=L M$

\begin{tabular}{|cc|c|c|c|c|c|}
\hline \multirow{2}{*}{ zsplusz } & & $\mathrm{N}$ & \multicolumn{5}{|c|}{ Subset } \\
\cline { 4 - 7 } & & & 1 & 2 & 3 & 4 \\
\hline & 5,00 & 3 & 8,9333 & & & \\
Tukey & 4,00 & 3 & 9,1667 & 9,1667 & & \\
HSD $^{\text {a,b,c }}$ & 3,00 & 3 & & 9,3667 & & \\
& 2,00 & 3 & & & 10,2667 & \\
& Sig. & &, 219 &, 341 & 1,000 & 1,000 \\
\hline
\end{tabular}


pH EV $=2012,00 \mathrm{KEZ}=\mathrm{C}$

\begin{tabular}{|c|c|c|c|c|c|c|}
\hline \multirow{2}{*}{\multicolumn{2}{|c|}{ zsplusz }} & \multirow{2}{*}{$\mathrm{N}$} & \multicolumn{4}{|c|}{ Subset } \\
\hline & & & 1 & 2 & 3 & 4 \\
\hline \multirow{6}{*}{ GH } & 2,00 & 3 & 2,9533 & & & \\
\hline & 3,00 & 3 & & 3,1000 & & \\
\hline & 4,00 & 3 & & 3,1433 & & \\
\hline & 7,00 & 3 & & & 3,2533 & \\
\hline & 5,00 & 3 & & & & 3,3167 \\
\hline & Sig. & & 1,000 & 1,000 & 1,000 & 1,000 \\
\hline
\end{tabular}

pH EV $=2013,00 \mathrm{KEZ}=\mathrm{C}$

\begin{tabular}{|cc|c|c|c|c|c|}
\hline \multirow{2}{*}{ zsplusz } & & \multirow{2}{*}{$\mathrm{N}$} & \multicolumn{5}{|c|}{ Subset } \\
\cline { 4 - 7 } & & & 1 & 2 & 3 & 4 \\
\hline & 2,00 & 3 & 2,8033 & & & \\
Tukey & 4,00 & 3 & & 2,8533 & & \\
HSD $^{\mathrm{a}, \mathrm{b}, \mathrm{c}}$ & 5,00 & 3 & & & 2,9033 & \\
& 7,00 & 3 & & & & 2,9333 \\
& Sig. & & 1,000 & 1,000 & 1,000 &, 283 \\
\hline
\end{tabular}

pH EV $=2012,00 \mathrm{KEZ}=\mathrm{LM}$

\begin{tabular}{|c|c|c|c|c|c|c|}
\hline \multirow{2}{*}{ zsplusz } & & \multirow{2}{*}{$\mathrm{N}$} & \multicolumn{4}{|c|}{ Subset } \\
\hline & & & 1 & 2 & 3 & 4 \\
\hline \multirow{6}{*}{$\begin{array}{c}\text { Tukey } \\
\text { HSD }^{\mathrm{a}, \mathrm{b}, \mathrm{c}}\end{array}$} & 2,00 & 3 & 2,8867 & & \multirow{5}{*}{3,2300} & \\
\hline & 3,00 & 3 & & 3,1400 & & \\
\hline & 4,00 & 3 & & & & \\
\hline & 7,00 & 3 & & & & 3,3367 \\
\hline & 5,00 & 3 & & & & 3,3433 \\
\hline & Sig. & & 1,000 & 1,000 & 1,000 & ,702 \\
\hline
\end{tabular}

pH EV=2013,00KEZ $=$ LM

\begin{tabular}{|cc|c|c|c|c|c|}
\hline \multirow{2}{*}{ zsplusz } & & \multirow{2}{*}{$\mathrm{N}$} & \multicolumn{4}{|c|}{ Subset } \\
\cline { 4 - 7 } & & & 1 & 2 & 3 & 4 \\
\hline & 7,00 & 3 & 2,8900 & & & \\
Tukey & 2,00 & 3 & 2,9067 & & & \\
HSD $^{\text {a,b,c }}$ & 3,00 & 3 & & 2,9367 & & \\
& 5,00 & 3 & & & 2,9800 & \\
& Sig. & &, 136 & 1,000 & 1,000 & 1,000 \\
\hline
\end{tabular}


Bogyótömeg EV=2012,00KEZ $=C$

\begin{tabular}{|cc|c|c|c|c|c|}
\hline \multirow{2}{*}{ zsplusz } & & \multirow{2}{*}{$\mathrm{N}$} & \multicolumn{5}{|c|}{ Subset } \\
\cline { 4 - 7 } & 5,00 & 3 & 1,252267 & & & \\
& 4,00 & 3 & 1,278300 & 1,278300 & & \\
Tukey & 7,00 & 3 & & 1,346000 & 1,346000 & \\
HSD $^{\mathrm{a}, \mathrm{b}, \mathrm{c}}$ & 2,00 & 3 & & & 1,374067 & 1,374067 \\
& 3,00 & 3 & & & & 1,418067 \\
& Sig. & &, 727 &, 054 &, 673 &, 288 \\
\hline
\end{tabular}

Bogyótömeg $\mathrm{EV}=\mathbf{2 0 1 3 , 0 0 K E Z = C}$

\begin{tabular}{|cc|c|c|c|}
\hline \multirow{2}{*}{ zsplusz } & & \multirow{2}{*}{$\mathrm{N}$} & \multicolumn{2}{|c|}{ Subset } \\
\cline { 4 - 5 } & & & 1 & 2 \\
\hline & 7,00 & 3 & 1,471100 & \\
& 2,00 & 3 & 1,506033 & \\
Tukey & 3,00 & 3 & & 1,664900 \\
HSD $^{\mathrm{a}, \mathrm{b}, \mathrm{c}}$ & 5,00 & 3 & & 1,714267 \\
& 4,00 & 3 & & 1,734533 \\
& Sig. & &, 898 &, 446 \\
\hline
\end{tabular}

Bogyótömeg EV=2012,00KEZ $=\mathrm{LM}$

\begin{tabular}{|cc|c|c|c|}
\hline \multirow{2}{*}{ zsplusz } & \multirow{2}{*}{$\mathrm{N}$} & \multicolumn{2}{|c|}{ Subset } \\
\cline { 4 - 5 } & & & 1 & 2 \\
\hline & 5,00 & 3 & 1,215400 & \\
& 4,00 & 3 & & 1,346800 \\
Tukey & 3,00 & 3 & & 1,361433 \\
HSD $^{\mathrm{a}, \mathrm{b}, \mathrm{c}}$ & 7,00 & 3 & & 1,369167 \\
& 2,00 & 3 & & 1,379467 \\
& Sig. & & 1,000 &, 324 \\
\hline
\end{tabular}

Bogyótömeg EV=2013,00KEZ=LM

\begin{tabular}{|cc|c|c|c|}
\hline \multirow{2}{*}{ zsplusz } & & \multirow{2}{*}{$\mathrm{N}$} & \multicolumn{2}{|c|}{ Subset } \\
\cline { 4 - 5 } & & & 1 & 2 \\
\hline & 7,00 & 3 & 1,474600 & \\
& 2,00 & 3 & 1,515267 & \\
Tukey & 3,00 & 3 & & 1,691367 \\
HSD $^{\mathrm{a}, \mathrm{b}, \mathrm{c}}$ & 5,00 & 3 & & 1,756000 \\
& 4,00 & 3 & & 1,789800 \\
& Sig. & &, 840 &, 174 \\
\hline
\end{tabular}


A1 ev $=2012,00 \mathrm{kez}=C$

\begin{tabular}{|cc|c|c|c|}
\hline \multirow{2}{*}{ zsplusz } & \multirow{2}{*}{$\mathrm{N}$} & \multicolumn{2}{|c|}{ Subset } \\
\cline { 4 - 5 } & 2 & 3 & 1336,00 & \\
& 3 & 3 & & 1611,00 \\
Tukey & 4 & 3 & & 1754,00 \\
HSD $^{\mathrm{a}, \mathrm{b}, \mathrm{c}}$ & 5 & 3 & & 1780,33 \\
& 7 & 3 & & 1834,33 \\
& Sig. & & 1,000 &, 090 \\
\hline
\end{tabular}

\begin{tabular}{|cc|c|c|c|c|}
\hline A1 $\mathbf{e v}=\mathbf{2 0 1 3}, \mathbf{0 0 k e z}=\mathbf{C}$ \\
\hline \multirow{2}{*}{ zsplusz } & & $\mathrm{N}$ & \multicolumn{3}{|c|}{ Subset } \\
\cline { 4 - 6 } & 2 & 3 & 807,67 & & 3 \\
\hline Tukey & 5 & 3 & & 1038,00 & \\
HSD $^{\mathrm{a}, \mathrm{b}, \mathrm{c}}$ & 3 & 3 & & 1084,33 & \\
& 7 & 3 & & 1088,00 & \\
& Sig. & & 1,000 &, 817 & 1,000 \\
\hline
\end{tabular}

A1 ev $=2012,00 \mathrm{kez}=$ LM

\begin{tabular}{|cc|c|c|c|}
\hline \multirow{2}{*}{ zsplusz } & \multirow{2}{*}{$\mathrm{N}$} & \multicolumn{2}{|c|}{ Subset } \\
\cline { 4 - 5 } & 2 & 3 & 1443,33 & \\
& 3 & 3 & 1635,00 & 1635,00 \\
Tukey & 7 & 3 & & 1735,67 \\
HSD $^{\mathrm{a}, \mathrm{b}, \mathrm{c}}$ & 4 & 3 & & 1780,33 \\
& 5 & 3 & & 1888,33 \\
& Sig. & &, 224 &, 075 \\
\hline
\end{tabular}

\begin{tabular}{|cc|c|c|c|c|c|}
\hline \multirow{2}{*}{ zsplusz } & \multirow{2}{*}{$\mathrm{N}$} & \multicolumn{5}{|c|}{ Subset } \\
\cline { 4 - 7 } & 2 & 3 & 1089,67 & & & \\
\hline & 3 & 3 & 1137,67 & 1137,67 & & \\
Tukey & 4 & 3 & & 1273,00 & 1273,00 & \\
HSD ${ }^{\mathrm{a}, \mathrm{b}, \mathrm{c}}$ & 5 & 3 & & & 1385,67 & 1385,67 \\
& 7 & 3 & & & & 1433,00 \\
& Sig. & &, 778 &, 054 &, 124 &, 786 \\
\hline
\end{tabular}


A3.4 ev $=2012,00 \mathrm{kez}=C$

\begin{tabular}{|cr|c|c|c|}
\hline \multirow{2}{*}{ zsplusz } & \multirow{2}{*}{$\mathrm{N}$} & \multicolumn{2}{|c|}{ Subset } \\
\cline { 4 - 5 } & & & 1 & 2 \\
\hline & 2 & 3 & 651,67 & \\
Tukey & 5 & 3 & 725,33 & 725,33 \\
HSD $^{\mathrm{a}, \mathrm{b}, \mathrm{c}}$ & 4 & 3 & 801,00 & 801,00 \\
& 3 & 3 & & 827,67 \\
& Sig. & &, 055 & 843,00 \\
& & &
\end{tabular}

A3.4 ev $=2013,00 \mathrm{kez}=C$

\begin{tabular}{|cc|c|c|c|}
\hline \multirow{2}{*}{ zsplusz } & \multirow{2}{*}{$\mathrm{N}$} & \multicolumn{2}{|c|}{ Subset } \\
\cline { 4 - 5 } & & & 1 & 2 \\
\hline & 2 & 3 & 507,67 & \\
Tukey & 4 & 3 & 529,00 & 529,00 \\
HSD $^{\mathrm{a}, \mathrm{b}, \mathrm{c}}$ & 5 & 3 & 558,33 & 558,33 \\
& 7 & 3 & & 593,00 \\
& Sig. & &, 245 & 601,67 \\
& & &
\end{tabular}

A3.4 ev $=2012,00 \mathrm{kez}=$ LM

\begin{tabular}{|cc|c|c|c|c|c|}
\hline \multirow{2}{*}{ zsplusz } & \multirow{2}{*}{$\mathrm{N}$} & \multicolumn{5}{|c|}{ Subset } \\
\cline { 4 - 7 } & & & 1 & 2 & 3 & 4 \\
\hline & 7 & 3 & 709,33 & & & \\
Tukey & 5 & 3 & & 792,33 & & \\
HSD $^{\text {a,b,c }}$ & 3 & 3 & & 839,67 & 839,67 & \\
& 4 & 3 & & & 896,00 & 896,00 \\
& Sig. & & 1,000 &, 242 &, 131 &, 087 \\
\hline
\end{tabular}

A3.4 ev $=2013,00 \mathrm{kez}=$ LM

\begin{tabular}{|cc|c|c|c|}
\hline \multirow{2}{*}{ zsplusz } & \multirow{2}{*}{$\mathrm{N}$} & \multicolumn{2}{|c|}{ Subset } \\
\cline { 4 - 5 } & 2 & 3 & 665,67 & \\
& 3 & 3 & 683,67 & 683,67 \\
Tukey & 4 & 3 & 701,67 & 701,67 \\
HSD $^{\mathrm{a}, \mathrm{b}, \mathrm{c}}$ & 5 & 3 & 734,00 & 734,00 \\
& 7 & 3 & & 760,67 \\
& Sig. & &, 179 &, 113 \\
\hline
\end{tabular}


EA ev $=2012,00 \mathrm{kez}=C$

\begin{tabular}{|cc|c|c|c|}
\hline \multirow{2}{*}{ zsplusz } & \multirow{2}{*}{$\mathrm{N}$} & \multicolumn{2}{|c|}{ Subset } \\
\cline { 3 - 5 } & 3 & 3 & 47,60 & \\
\hline & 2 & 3 & 51,03 & 51,03 \\
Tukey & 4 & 3 & 52,87 & 52,87 \\
HSD $^{\mathrm{a}, \mathrm{b}, \mathrm{c}}$ & 5 & 3 & 54,93 & 54,93 \\
& 7 & 3 & & 60,40 \\
& Sig. & &, 215 &, 083 \\
\hline
\end{tabular}

EA ev $=2013,00 \mathrm{kez}=C$

\begin{tabular}{|cc|c|c|c|c|}
\hline \multirow{2}{*}{ zsplusz } & & \multirow{2}{*}{$\mathrm{N}$} & \multicolumn{3}{|c|}{ Subset } \\
\cline { 4 - 6 } & 2 & 3 & 37,10 & 2 & 3 \\
\hline & 5 & 3 & 42,63 & 42,63 & \\
Tukey & 4 & 3 & 48,23 & 48,23 & 48,23 \\
HSD $^{\text {a,b,c }}$ & 3 & 3 & & 51,13 & 51,13 \\
& 7 & 3 & & & 55,60 \\
& Sig. & &, 084 &, 236 &, 352 \\
\hline
\end{tabular}

EA ev $=2012,00 \mathrm{kez}=\mathrm{LM}$

\begin{tabular}{|cr|c|c|c|c|}
\hline \multirow{2}{*}{ zsplusz } & \multirow{2}{*}{$\mathrm{N}$} & \multicolumn{3}{|c|}{ Subset } \\
\cline { 4 - 6 } & 3 & 3 & 45,10 & 2 & 3 \\
\hline & 4 & 3 & 46,10 & 46,10 & \\
Tukey & 2 & 3 & 50,57 & 50,57 & 50,57 \\
HSD $^{\text {a,b,c }}$ & 7 & 3 & & 54,23 & 54,23 \\
& 5 & 3 & & & 55,50 \\
& Sig. & &, 344 &, 087 &, 434 \\
\hline
\end{tabular}

EA ev $=2013,00 \mathrm{kez}=$ LM

\begin{tabular}{|cc|c|c|}
\hline \multirow{2}{*}{ zsplusz } & $\mathrm{N}$ & Subset \\
\cline { 3 - 4 } & 2 & 3 & 38,90 \\
& 3 & 3 & 39,80 \\
Tukey & 4 & 3 & 44,67 \\
HSD $^{\mathrm{a}, \mathrm{b}, \mathrm{c}}$ & 7 & 3 & 46,90 \\
& 5 & 3 & 46,93 \\
& Sig. & &, 154 \\
\hline
\end{tabular}


SM ev $=2012,00 \mathrm{kez}=C$

\begin{tabular}{|cc|c|c|c|}
\hline \multirow{2}{*}{ zsplusz } & \multirow{2}{*}{$\mathrm{N}$} & \multicolumn{2}{|c|}{ Subset } \\
\cline { 4 - 5 } & & & 1 & 2 \\
\hline & 3 & 3 & 47,23 & \\
Tukey & 5 & 3 & 51,73 & \\
HSD $^{\mathrm{a}, \mathrm{b}, \mathrm{c}}$ & 4 & 3 & 58,77 & 55,77 \\
& 7 & 3 & & 58,27 \\
& Sig. & &, 134 &, 147 \\
\hline
\end{tabular}

SM ev $=2013,00 \mathrm{kez}=C$

\begin{tabular}{|cc|c|c|}
\hline \multicolumn{2}{|c|}{ Zsplusz } & N & Subset \\
\cline { 3 - 4 } & & & 1 \\
\hline & 7 & 3 & 48,97 \\
& 5 & 3 & 57,47 \\
Tukey $_{\text {HSD }}^{\text {a,b,c }}$ & 3 & 3 & 66,77 \\
& 4 & 3 & 69,47 \\
& 2 & 3 & 71,83 \\
& Sig. & &, 068 \\
\hline
\end{tabular}

SM ev=2012,00kez $=$ LM

\begin{tabular}{|cr|c|c|}
\hline \multirow{2}{*}{ zsplusz } & \multirow{2}{*}{$\mathrm{N}$} & Subset \\
\cline { 4 - 4 } & & & 1 \\
\hline & 4 & 3 & 55,77 \\
& 3 & 3 & 56,07 \\
Tukey & 7 & 3 & 56,17 \\
HSD $^{\text {a,b,c }}$ & 5 & 3 & 65,37 \\
& 2 & 3 & 66,40 \\
& Sig. & &, 086 \\
\hline
\end{tabular}

SM ev $=2013,00 \mathrm{kez}=L M$

\begin{tabular}{|cc|c|c|}
\hline \multirow{2}{*}{ zsplusz } & \multirow{2}{*}{ N } & Subset \\
& & & 1 \\
\hline \multirow{4}{*}{ GH } & 7 & 3 & 56,07 \\
& 3 & 3 & 65,03 \\
& 4 & 3 & 65,47 \\
& 5 & 3 & 67,33 \\
& 2 & 3 & 69,40 \\
& Sig. & &, 213 \\
\hline
\end{tabular}


Fsk ev $=2012,00 \mathrm{kez}=\mathrm{C}$

\begin{tabular}{|cc|c|c|c|}
\hline \multirow{2}{*}{ zsplusz } & \multirow{2}{*}{$\mathrm{N}$} & \multicolumn{2}{|c|}{ Subset } \\
\cline { 4 - 5 } & & & 1 & 2 \\
\hline & 5,00 & 50 &, 4093 & \\
Tukey & 3,00 & 50 &, 4423 &, 4423 \\
HSD $^{\mathrm{a}, \mathrm{b}, \mathrm{c}}$ & 4,00 & 50 & &, 4597 \\
& 2,00 & 50 & &, 4721 \\
& Sig. & & &, 4755 \\
& & &, 169 &, 162 \\
\hline
\end{tabular}

Fsk ev $=2013,00 \mathrm{kez}=C$

\begin{tabular}{|cc|c|c|c|}
\hline \multirow{2}{*}{ zsplusz } & \multirow{2}{*}{$\mathrm{N}$} & \multicolumn{2}{|c|}{ Subset } \\
\cline { 4 - 5 } & & & 1 & 2 \\
\hline & 4,00 & 50 &, 4498 & \\
& 7,00 & 50 &, 4585 &, 4585 \\
Tukey & 5,00 & 50 &, 4693 &, 4693 \\
HSD $^{\mathrm{a}, \mathrm{b}, \mathrm{c}}$ & 3,00 & 50 &, 4806 &, 4806 \\
& 2,00 & 50 & &, 5136 \\
& Sig. & &, 544 &, 052 \\
\hline
\end{tabular}

Fsk ev $=2012,00 \mathrm{kez}=$ LM

\begin{tabular}{|cc|c|c|c|}
\hline \multirow{2}{*}{ zsplusz } & \multirow{2}{*}{$\mathrm{N}$} & \multicolumn{2}{|c|}{ Subset } \\
\cline { 4 - 5 } & & & 1 & 2 \\
\hline \multirow{4}{*}{ GH } & 5,00 & 50 &, 4223 & \\
& 4,00 & 50 &, 4334 &, 4334 \\
& 3,00 & 50 &, 4497 &, 4497 \\
& 7,00 & 50 &, 4526 &, 4526 \\
& 2,00 & 50 & &, 4704 \\
& Sig. & &, 349 &, 165 \\
\hline
\end{tabular}

Fsk ev $=2013,00 \mathrm{kez}=$ LM

\begin{tabular}{|cc|c|c|c|}
\hline \multirow{2}{*}{ zsplusz } & \multirow{2}{*}{$\mathrm{N}$} & \multicolumn{2}{|c|}{ Subset } \\
\cline { 4 - 5 } & & & 1 & 2 \\
\hline & 5,00 & 50 &, 4142 & \\
& 7,00 & 50 &, 4152 & \\
Tukey & 4,00 & 50 &, 4339 &, 4339 \\
HSD $^{\mathrm{a}, \mathrm{b}, \mathrm{c}}$ & 3,00 & 50 &, 4346 &, 4346 \\
& 2,00 & 50 & &, 4703 \\
& Sig. & &, 827 &, 322 \\
\hline
\end{tabular}


Esk ev $=2012,00 \mathrm{kez}=C$

\begin{tabular}{|cc|c|c|c|c|}
\hline \multirow{2}{*}{ zsplusz } & & \multirow{4}{*}{$\mathrm{N}$} & \multicolumn{4}{|c|}{ Subset } \\
\cline { 5 - 7 } & & & 1 & 2 & 3 \\
\hline \multirow{4}{*}{ GH } & 4,00 & 50 &,- 8574 & & \\
& 5,00 & 50 &,- 8059 &,- 8059 & \\
& 7,00 & 50 & &,- 7283 &,- 7283 \\
& 3,00 & 50 & &,- 7134 &,- 7134 \\
& 2,00 & 50 & & &,- 6147 \\
& Sig. & &, 789 &, 254 &, 095 \\
\hline
\end{tabular}

Esk ev $=2013,00 \mathrm{kez}=\mathrm{C}$

\begin{tabular}{|cc|c|c|c|c|c|}
\hline \multirow{2}{*}{ zsplusz } & & \multirow{2}{*}{$\mathrm{N}$} & \multicolumn{5}{|c|}{ Subset } \\
\cline { 4 - 7 } & & & 1 & 2 & 3 & 4 \\
\hline \multirow{4}{*}{ GH } & 7,00 & 50 & $-1,1093$ & & & \\
& 5,00 & 50 & &,- 7542 & & \\
& 4,00 & 50 & & &,- 5986 & \\
& 3,00 & 50 & & &,- 5661 & \\
& 2,00 & 50 & & & &,- 4445 \\
& Sig. & & 1,000 & 1,000 &, 842 & 1,000 \\
\hline
\end{tabular}

Esk ev $=2012,00 \mathrm{kez}=$ LM

\begin{tabular}{|cc|c|c|c|}
\hline \multirow{2}{*}{ zsplusz } & \multirow{2}{*}{$\mathrm{N}$} & \multicolumn{2}{|c|}{ Subset } \\
\cline { 4 - 5 } & & & 1 & 2 \\
\hline \multirow{4}{*}{ GH } & 5,00 & 50 &,- 8385 & \\
& 4,00 & 50 &,- 8221 &,- 8221 \\
& 3,00 & 50 &,- 7362 &,- 7362 \\
& 7,00 & 50 &,- 6961 &,- 6961 \\
& 2,00 & 50 & &,- 6662 \\
& Sig. & &, 069 &, 698 \\
\hline
\end{tabular}

Esk ev $=2013,00 \mathrm{kez}=$ LM

\begin{tabular}{|c|c|c|c|c|c|c|}
\hline \multirow{2}{*}{ zsplusz } & & \multirow{2}{*}{$\mathrm{N}$} & \multicolumn{4}{|c|}{ Subset } \\
\hline & & & 1 & 2 & 3 & 4 \\
\hline \multirow{6}{*}{$\begin{array}{l}\text { Tukey } \\
\text { HSD }^{\mathrm{a}, \mathrm{b}, \mathrm{c}}\end{array}$} & 7,00 & 50 & $-1,0054$ & & & \\
\hline & 5,00 & 50 & &,- 7073 & & \\
\hline & 4,00 & 50 & &,- 6575 &,- 6575 & \\
\hline & 3,00 & 50 & & &,- 5958 & \\
\hline & 2,00 & 50 & & & &,- 4743 \\
\hline & Sig. & & 1,000 &, 506 & ,285 & 1,000 \\
\hline
\end{tabular}


Wsk ev $=2012,00 \mathrm{kez}=\mathrm{C}$

\begin{tabular}{|cc|c|c|c|}
\hline \multirow{2}{*}{ zsplusz } & \multirow{2}{*}{$\mathrm{N}$} & \multicolumn{2}{|c|}{ Subset } \\
\cline { 4 - 5 } & & & 1 & 2 \\
\hline \multirow{4}{*}{ GH } & 5,00 & 50 &, 2316 & \\
& 7,00 & 50 &, 2443 & \\
& 2,00 & 50 &, 2480 & \\
& 3,00 & 50 &, 2617 &, 2617 \\
& 4,00 & 50 & &, 3125 \\
& Sig. & &, 351 & 1,000 \\
\hline
\end{tabular}

Wsk ev $=2013,00 \mathrm{kez}=\mathrm{C}$

\begin{tabular}{|cc|c|c|c|c|}
\hline \multirow{2}{*}{ zsplusz } & & \multirow{2}{*}{$\mathrm{N}$} & \multicolumn{4}{|c|}{ Subset } \\
\cline { 5 - 6 } & & & 1 & 2 & 3 \\
\hline & 4,00 & 50 &, 2259 & & \\
& 3,00 & 50 &, 2479 &, 2479 & \\
Tukey & 2,00 & 50 &, 2534 &, 2534 & \\
HSD $^{\mathrm{a}, \mathrm{b}, \mathrm{c}}$ & 5,00 & 50 & &, 2834 & \\
& 7,00 & 50 & & &, 3424 \\
& Sig. & &, 566 &, 306 & 1,000 \\
\hline
\end{tabular}

Wsk ev $=2012,00 \mathrm{kez}=\mathrm{LM}$

\begin{tabular}{|cc|c|c|}
\hline \multirow{2}{*}{ zsplusz } & & $\mathrm{N}$ & Subset \\
\cline { 4 - 4 } & & & 1 \\
\hline & 5,00 & 50 &, 2472 \\
Tukey & 2,00 & 50 &, 2520 \\
HSD $^{\text {a,b,c }}$ & 3,00 & 50 &, 2550 \\
& 4,00 & 50 &, 2560 \\
& Sig. & &, 947 \\
\hline
\end{tabular}

Wsk ev $=2013,00 \mathrm{kez}=$ LM

\begin{tabular}{|cc|c|c|c|}
\hline \multirow{2}{*}{ zsplusz } & & \multirow{2}{*}{$\mathrm{N}$} & \multicolumn{2}{|c|}{ Subset } \\
\cline { 4 - 5 } & & & 1 & 2 \\
\hline & 3,00 & 50 &, 2133 & \\
& 2,00 & 50 &, 2220 & \\
Tukey & 5,00 & 50 &, 2237 & \\
HSD $^{\mathrm{a}, \mathrm{b}, \mathrm{c}}$ & 4,00 & 50 &, 2326 &, 2326 \\
& 7,00 & 50 & &, 2706 \\
& Sig. & &, 782 &, 162 \\
\hline
\end{tabular}


BH ev $=2102,00 \mathrm{kez}=C$

\begin{tabular}{|cc|c|c|c|c|}
\hline \multirow{2}{*}{ zsplusz } & & \multirow{4}{*}{$\mathrm{N}$} & \multicolumn{3}{|c|}{ Subset } \\
\cline { 5 - 7 } & & & 1 & 2 & 3 \\
\hline \multirow{4}{*}{ GH } & 5,00 & 50 & 1,2007 & & \\
& 4,00 & 50 & 1,2474 & & \\
& 7,00 & 50 & 1,2954 & 1,2954 & \\
& 3,00 & 50 & & 1,3671 & 1,3671 \\
& 2,00 & 50 & & & 1,4892 \\
& Sig. & &, 276 &, 091 &, 081 \\
\hline
\end{tabular}

BH ev $=2103,00 \mathrm{kez}=C$

\begin{tabular}{|cc|c|c|c|c|c|}
\hline \multirow{2}{*}{ zsplusz } & & \multirow{2}{*}{$\mathrm{N}$} & \multicolumn{5}{|c|}{ Subset } \\
\cline { 4 - 7 } & & & 1 & 2 & 3 & 4 \\
\hline \multirow{4}{*}{ GH } & 7,00 & 50 & 1,2325 & & & \\
& 5,00 & 50 & & 1,3805 & & \\
& 4,00 & 50 & & 1,4672 & 1,4672 & \\
& 3,00 & 50 & & & 1,5171 & \\
& 2,00 & 50 & & & & 1,6632 \\
& Sig. & & 1,000 &, 152 &, 680 & 1,000 \\
\hline
\end{tabular}

BH ev $=2102,00 \mathrm{kez}=\mathrm{LM}$

\begin{tabular}{|cc|c|c|c|c|}
\hline \multirow{2}{*}{ zsplusz } & \multirow{2}{*}{$\mathrm{N}$} & \multicolumn{3}{|c|}{ Subset } \\
\cline { 5 - 7 } & & & 1 & 2 & 3 \\
\hline \multirow{4}{*}{ GH } & 5,00 & 50 & 1,2485 & & \\
& 4,00 & 50 & 1,3482 & 1,3482 & \\
& 7,00 & 50 & & 1,3980 & \\
& 3,00 & 50 & & 1,4050 & \\
& 2,00 & 50 & & & 1,5889 \\
& Sig. & &, 188 &, 725 & 1,000 \\
\hline
\end{tabular}

BH ev $=2103,00 \mathrm{kez}=\mathrm{LM}$

\begin{tabular}{|cc|c|c|c|}
\hline \multirow{2}{*}{ zsplusz } & \multirow{2}{*}{$\mathrm{N}$} & \multicolumn{2}{|c|}{ Subset } \\
\cline { 4 - 5 } & & & 1 & 2 \\
\hline & 7,00 & 50 & 1,2017 & \\
Tukey $_{\text {HSD }}^{\text {a,b,c }}$ & 4,00 & 50 & 1,2328 & \\
& 3,00 & 50 & & 1,4640 \\
& 2,00 & 50 & & 1,5052 \\
& Sig. & &, 942 & 1,5638 \\
\end{tabular}




\begin{tabular}{|cc|c|c|c|}
\multicolumn{2}{|c|}{ BCo ev=2102,00kez $=\mathbf{C}$} \\
\hline \multirow{2}{*}{ zsplusz } & & \multirow{2}{*}{$\mathrm{N}$} & \multicolumn{2}{|c|}{ Subset } \\
\cline { 4 - 6 } & & & 1 & 2 \\
\hline \multirow{4}{*}{ GH } & 2,00 & 50 &, 3761 & \\
& 5,00 & 50 &, 3989 & \\
& 3,00 & 50 &, 3998 & \\
& 7,00 & 50 &, 4133 &, 4133 \\
& 4,00 & 50 & &, 4456 \\
& Sig. & &, 111 &, 217 \\
\hline
\end{tabular}

BCo ev $=2103,00 \mathrm{kez}=C$

\begin{tabular}{|cc|c|c|c|c|c|}
\hline \multirow{2}{*}{ zsplusz } & & $\mathrm{N}$ & \multicolumn{5}{|c|}{ Subset } \\
\cline { 4 - 7 } & 2,00 & 50 &, 3387 & & & \\
& 4,00 & 50 &, 3407 & & & \\
Tukey & 3,00 & 50 & &, 3834 & & \\
HSD $^{\mathbf{a}, \mathbf{b}, \mathbf{c}}$ & 7,00 & 50 & & &, 4302 & \\
& 5,00 & 50 & & & &, 4752 \\
& Sig. & & 1,000 & 1,000 & 1,000 & 1,000 \\
\hline
\end{tabular}

BCo ev $=2102,00 \mathrm{kez}=\mathrm{LM}$

\begin{tabular}{|cc|c|c|c|}
\hline \multirow{2}{*}{ zsplusz } & \multirow{2}{*}{$\mathrm{N}$} & \multicolumn{2}{|c|}{ Subset } \\
\cline { 4 - 5 } & & & 1 & 2 \\
\hline & 2,00 & 50 &, 3454 & \\
Tukey & 3,00 & 50 &, 3793 &, 3793 \\
HSD $^{\mathbf{a}, \mathbf{b}, \mathbf{c}}$ & 4,00 & 50 &, 3846 &, 3846 \\
& 5,00 & 50 &, 3893 &, 3893 \\
& Sig. & &, 071 &, 4016 \\
& &
\end{tabular}

BCo ev=2103,00kez $=$ LM

\begin{tabular}{|cc|c|c|c|c|}
\hline \multirow{2}{*}{ zsplusz } & & \multirow{2}{*}{$\mathrm{N}$} & \multicolumn{3}{|c|}{ Subset } \\
\cline { 4 - 6 } & & & 1 & 2 & 3 \\
\hline & 3,00 & 50 &, 3657 & & \\
& 2,00 & 50 &, 3742 &, 3742 & \\
Tukey $_{\text {HSD }}^{\text {a,b,c }}$ & 4,00 & 50 & &, 4098 &, 4098 \\
& 5,00 & 50 & &, 4129 &, 4129 \\
& 7,00 & 50 & & &, 4403 \\
& Sig. & &, 976 &, 061 &, 220 \\
\hline
\end{tabular}


BG ev $=2102,00 \mathrm{kez}=C$

\begin{tabular}{|cc|c|c|c|c|}
\hline \multirow{2}{*}{ zsplusz } & & \multirow{2}{*}{$\mathrm{N}$} & \multicolumn{3}{|c|}{ Subset } \\
\cline { 4 - 6 } & & & 1 & 2 & 3 \\
\hline \multirow{4}{*}{ GH } & 5,00 & 50 & 1,4516 & & \\
& 4,00 & 50 & 1,5226 & 1,5226 & \\
& 7,00 & 50 & & 1,5362 & \\
& 3,00 & 50 & & 1,5714 & 1,5714 \\
& 2,00 & 50 & & & 1,6459 \\
& Sig. & &, 114 &, 460 &, 086 \\
\hline
\end{tabular}

BG ev $=2103,00 \mathrm{kez}=C$

\begin{tabular}{|cc|c|c|c|c|c|}
\hline \multirow{2}{*}{ zsplusz } & & \multirow{2}{*}{$\mathrm{N}$} & \multicolumn{5}{|c|}{ Subset } \\
\cline { 4 - 7 } & & & 1 & 2 & 3 & 4 \\
\hline & 7,00 & 50 & 1,5066 & & & \\
Tukey & 5,00 & 50 & 1,5842 & 1,5842 & & \\
HSD $^{\mathbf{a}, \mathbf{b}, \mathbf{c}}$ & 3,00 & 50 & & 1,6595 & 1,6595 & \\
& 2,00 & 50 & & & 1,6793 & 1,6793 \\
& Sig. & &, 093 &, 111 &, 968 &, 172 \\
\hline
\end{tabular}

BG ev $=2102,00 \mathrm{kez}=\mathrm{LM}$

\begin{tabular}{|cc|c|c|c|c|}
\hline \multirow{2}{*}{ zsplusz } & \multirow{2}{*}{$\mathrm{N}$} & \multicolumn{3}{|c|}{ Subset } \\
\cline { 5 - 7 } & & & 1 & 2 & 3 \\
\hline \multirow{4}{*}{ GH } & 5,00 & 50 & 1,4868 & & \\
& 4,00 & 50 & 1,5462 & 1,5462 & \\
& 7,00 & 50 & & 1,5856 & \\
& 3,00 & 50 & & 1,5858 & \\
& 2,00 & 50 & & & 1,6893 \\
& Sig. & &, 300 &, 694 & 1,000 \\
\hline
\end{tabular}

BG ev $=2103,00 \mathrm{kez}=\mathrm{LM}$

\begin{tabular}{|cc|c|c|c|}
\hline \multirow{2}{*}{ zsplusz } & & \multirow{N}{*}{$\mathrm{N}$} & \multicolumn{2}{|c|}{ Subset } \\
\cline { 4 - 5 } & & & 1 & 2 \\
\hline & 7,00 & 50 & 1,4872 & \\
Tukey $_{\text {HSD }}^{\text {a,b,c }}$ & 3,00 & 50 & 1,4874 & \\
& 4,00 & 50 & & 1,6509 \\
& 2,00 & 50 & & 1,6642 \\
& Sig. & & 1,000 & 1,7129 \\
\end{tabular}


BS ev $=2102,00 \mathrm{kez}=C$

\begin{tabular}{|cc|c|c|c|}
\hline \multirow{2}{*}{ zsplusz } & \multirow{2}{*}{$\mathrm{N}$} & \multicolumn{2}{|c|}{ Subset } \\
\cline { 4 - 5 } & & & 1 & 2 \\
\hline & 5,00 & 50 & 2,6388 & \\
& 2,00 & 50 & 2,6628 & 2,6628 \\
Tukey $_{\text {HSD }}^{\mathbf{a , b}, \mathbf{c}}$ & 7,00 & 50 & 2,6996 & 2,6996 \\
& 4,00 & 50 & 2,7292 & 2,7292 \\
& 3,00 & 50 & & 2,7672 \\
& Sig. & &, 229 &, 116 \\
\hline
\end{tabular}

BS ev $=2103,00 \mathrm{kez}=C$

\begin{tabular}{|cc|c|c|c|}
\hline \multirow{2}{*}{ zsplusz } & & \multirow{2}{*}{$\mathrm{N}$} & \multicolumn{2}{|c|}{ Subset } \\
\cline { 4 - 5 } & & & 1 & 2 \\
\hline \multirow{4}{*}{ GH } & 4,00 & 50 & 2,7586 & \\
& 7,00 & 50 & 2,7616 & \\
& 2,00 & 50 & 2,7754 & \\
& 3,00 & 50 & & 2,9608 \\
& 5,00 & 50 & & 3,0546 \\
& Sig. & &, 997 &, 358 \\
\hline
\end{tabular}

BS ev $=2102,00 \mathrm{kez}=L M$

\begin{tabular}{|cc|c|c|}
\hline \multirow{2}{*}{ zsplusz } & & $\mathrm{N}$ & Subset \\
\cline { 4 - 4 } & & & 1 \\
\hline & 2,00 & 50 & 2,6166 \\
& 5,00 & 50 & 2,6586 \\
Tukey $_{\text {HSD }}^{\text {a,b,c }}$ & 7,00 & 50 & 2,6740 \\
& 3,00 & 50 & 2,7100 \\
& 4,00 & 50 & 2,7310 \\
& Sig. & &, 088 \\
\hline
\end{tabular}

BS ev $=2103,00 \mathrm{kez}=\mathrm{LM}$

\begin{tabular}{|cc|c|c|c|c|c|}
\hline \multirow{2}{*}{ zsplusz } & \multirow{2}{*}{$\mathrm{N}$} & \multicolumn{5}{|c|}{ Subset } \\
\cline { 4 - 7 } & & & 1 & 2 & 3 & 4 \\
\hline & 7,00 & 50 & 2,6240 & & & \\
Tukey $^{*}$ & 3,00 & 50 & & 2,7938 & & \\
HSD $^{\mathbf{a}, \mathbf{b}, \mathbf{c}}$ & 2,00 & 50 & & 2,9212 & 2,9212 & \\
& 4,00 & 50 & & & 2,9674 & \\
& Sig. & & 1,000 &, 110 &, 903 & 1,000 \\
\hline
\end{tabular}


BCh ev $=2102,00 \mathrm{kez}=C$

\begin{tabular}{|cc|c|c|c|c|}
\hline \multirow{2}{*}{ zsplusz } & \multirow{2}{*}{$\mathrm{N}$} & \multicolumn{3}{|c|}{ Subset } \\
\cline { 4 - 6 } & & & 1 & 2 & 3 \\
\hline & 5,00 & 50 & 2,3634 & & \\
Tukey & 7,00 & 50 & 2,5160 & 2,5160 & \\
HSD $^{\mathbf{a , b , c}}$ & 3,00 & 50 & & 2,5248 & \\
& 2,00 & 50 & & 2,6129 & 2,6129 \\
& Sig. & &, 052 & & \\
& & & & \\
& & & & & \\
\end{tabular}

BCh ev $=2103,00 \mathrm{kez}=C$

\begin{tabular}{|cc|c|c|c|}
\hline \multirow{2}{*}{ zsplusz } & & \multirow{N}{*}{$\mathrm{N}$} & \multicolumn{2}{|c|}{ Subset } \\
\cline { 4 - 5 } & & & 1 & 2 \\
\hline & 7,00 & 50 & 2,5074 & \\
& 4,00 & 50 & 2,6315 & \\
Tukey $_{\text {HSD }}^{\mathbf{a , b}, \mathbf{c}}$ & 3,00 & 50 & & 2,8868 \\
& 5,00 & 50 & & 2,9025 \\
& 2,00 & 50 & & 2,9140 \\
& Sig. & &, 290 &, 993 \\
\hline
\end{tabular}

BCh ev $=2102,00 \mathrm{kez}=\mathrm{LM}$

\begin{tabular}{|cc|c|c|c|c|}
\hline \multirow{2}{*}{ zsplusz } & \multirow{2}{*}{$\mathrm{N}$} & \multicolumn{3}{|c|}{ Subset } \\
\cline { 4 - 6 } & & & 1 & 2 & 3 \\
\hline \multirow{4}{*}{ GH } & 5,00 & 50 & 2,4277 & & \\
& 4,00 & 50 & 2,5566 & 2,5566 & \\
& 7,00 & 50 & 2,5985 & 2,5985 & 2,5985 \\
& 3,00 & 50 & & 2,6105 & 2,6105 \\
& 2,00 & 50 & & & 2,7296 \\
& Sig. & &, 215 &, 902 &, 201 \\
\hline
\end{tabular}

BCh ev $=2103,00 \mathrm{kez}=\mathrm{LM}$

\begin{tabular}{|cc|c|c|c|}
\hline \multirow{2}{*}{ zsplusz } & & \multirow{N}{*}{$\mathrm{N}$} & \multicolumn{2}{|c|}{ Subset } \\
\cline { 4 - 5 } & & & 1 & 2 \\
\hline & 7,00 & 50 & 2,4134 & \\
& 5,00 & 50 & 2,4916 & \\
Tukey $_{\text {HSD }}^{\text {a,b,c }}$ & 3,00 & 50 & & 2,8252 \\
& 2,00 & 50 & & 2,9527 \\
& 4,00 & 50 & & 2,9700 \\
& Sig. & &, 832 &, 297 \\
\hline
\end{tabular}


BR ev $=2102,00 \mathrm{kez}=C$

\begin{tabular}{|cc|c|c|c|}
\hline \multirow{2}{*}{ zsplusz } & \multirow{2}{*}{$\mathrm{N}$} & \multicolumn{2}{|c|}{ Subset } \\
\cline { 4 - 5 } & & & 1 & 2 \\
\hline & 2,00 & 50 &, 2890 & \\
Tukey $_{\text {HSD }}^{\text {a,b,c }}$ & 3,00 & 50 &, 2988 & \\
& 3,00 & 50 &, 3001 &, 3001 \\
& 7,00 & 50 &, 3056 &, 3056 \\
& 4,00 & 50 & &, 3219 \\
& Sig. & &, 275 &, 071 \\
\hline
\end{tabular}

BR ev $=2103,00 \mathrm{kez}=C$

\begin{tabular}{|cc|c|c|c|c|}
\hline \multirow{2}{*}{ zsplusz } & & \multirow{2}{*}{$\mathrm{N}$} & \multicolumn{3}{|c|}{ Subset } \\
\cline { 5 - 6 } & & & 1 & 2 & 3 \\
\hline & 4,00 & 50 &, 2738 & & \\
& 2,00 & 50 &, 2790 &, 2790 & \\
Tukey & 7,00 & 50 &, 2942 &, 2942 & \\
HSD $^{\text {a,b,c }}$ & 3,00 & 50 & &, 2972 & \\
& 5,00 & 50 & & &, 3534 \\
& Sig. & &, 066 &, 129 & 1,000 \\
\hline
\end{tabular}

BR ev $=2102,00 \mathrm{kez}=\mathrm{LM}$

\begin{tabular}{|cc|c|c|c|}
\hline \multirow{2}{*}{ zsplusz } & \multirow{2}{*}{$\mathrm{N}$} & \multicolumn{2}{|c|}{ Subset } \\
\cline { 4 - 5 } & & & 1 & 2 \\
\hline & 2,00 & 50 &, 2715 & \\
& 7,00 & 50 &, 2829 &, 2829 \\
Tukey & 3,00 & 50 &, 2886 &, 2886 \\
HSD $^{\mathbf{a}, \mathbf{b}, \mathbf{c}}$ & 4,00 & 50 &, 2939 &, 2939 \\
& 5,00 & 50 & &, 3028 \\
& Sig. & &, 068 &, 136 \\
\hline
\end{tabular}

BR ev $=2103,00 \mathrm{kez}=\mathrm{LM}$

\begin{tabular}{|cc|c|c|c|}
\hline \multirow{2}{*}{ zsplusz } & & \multirow{2}{*}{$\mathrm{N}$} & \multicolumn{2}{|c|}{ Subset } \\
\cline { 4 - 5 } & & & 1 & 2 \\
\hline & 7,00 & 50 &, 2849 & \\
Tukey $_{\text {HSD }}^{\text {a,b,c }}$ & 2,00 & 50 &, 2877 & \\
& 2,00 & 50 &, 3047 &, 3047 \\
& 5,00 & 50 & &, 3135 \\
& 4,00 & 50 & &, 3171 \\
& Sig. & &, 065 &, 470 \\
\hline
\end{tabular}


Fs ev $=2012,00 \mathrm{kez}=C$

\begin{tabular}{|cr|c|c|}
\hline \multirow{2}{*}{ zsplusz } & & $\mathrm{N}$ & Subset \\
\cline { 4 - 4 } & & & 1 \\
\hline & 7,00 & 50 & 37,8572 \\
& 3,00 & 50 & 38,2230 \\
Tukey & 4,00 & 50 & 38,4964 \\
HSD $^{\mathrm{a}, \mathrm{b}, \mathrm{c}}$ & 5,00 & 50 & 38,5210 \\
& 2,00 & 50 & 40,2772 \\
& Sig. & &, 636 \\
\hline
\end{tabular}

Fs ev $=2013,00 \mathrm{kez}=C$

\begin{tabular}{|cc|c|c|c|}
\hline \multirow{2}{*}{ zsplusz } & & \multirow{2}{*}{$\mathrm{N}$} & \multicolumn{2}{|c|}{ Subset } \\
\cline { 4 - 5 } & & & 1 & 2 \\
\hline & 3,00 & 50 & 30,6622 & \\
& 4,00 & 50 & 30,7658 & \\
Tukey & 2,00 & 50 & 31,0600 & \\
HSD ${ }^{\mathrm{a}, \mathrm{b}, \mathrm{c}}$ & 7,00 & 50 & 33,3514 & 33,3514 \\
& 5,00 & 50 & & 35,6004 \\
& Sig. & &, 240 &, 420 \\
\hline
\end{tabular}

Fs ev $=2012,00 \mathrm{kez}=\mathrm{LM}$

\begin{tabular}{|cr|c|c|}
\hline \multirow{2}{*}{ zsplusz } & & $\mathrm{N}$ & Subset \\
\cline { 4 - 4 } & & & 1 \\
\hline & 2,00 & 50 & 37,4222 \\
& 5,00 & 50 & 37,6082 \\
Tukey & 4,00 & 50 & 38,8792 \\
HSD $^{\text {a,b,c }}$ & 7,00 & 50 & 39,9106 \\
& 3,00 & 50 & 41,2696 \\
& Sig. & &, 221 \\
\hline
\end{tabular}

Fs ev $=2013,00 \mathrm{kez}=\mathrm{LM}$

\begin{tabular}{|cc|c|c|c|}
\hline \multirow{2}{*}{ zsplusz } & \multirow{2}{*}{$\mathrm{N}$} & \multicolumn{2}{|c|}{ Subset } \\
\cline { 4 - 5 } & & & 1 & 2 \\
\hline & 3,00 & 50 & 29,7380 & \\
& 2,00 & 50 & 29,9720 & \\
Tukey & 7,00 & 50 & 33,1372 & 33,1372 \\
HSD $^{\mathrm{a}, \mathrm{b}, \mathrm{c}}$ & 4,00 & 50 & & 33,8536 \\
& 5,00 & 50 & & 34,6054 \\
& Sig. & &, 092 &, 815 \\
\hline
\end{tabular}


Es ev $=2012,00 \mathrm{kez}=C$

\begin{tabular}{|cc|c|c|c|}
\hline \multirow{2}{*}{ zsplusz } & \multirow{2}{*}{$\mathrm{N}$} & \multicolumn{2}{|c|}{ Subset } \\
\cline { 4 - 5 } & & & 1 & 2 \\
\hline & 2,00 & 50 & 63,9318 & \\
Tukey & 3,00 & 50 & 67,4748 & 67,4748 \\
HSD $^{\mathrm{a}, \mathrm{b}, \mathrm{c}}$ & 5,00 & 50 & 68,3106 & 68,3106 \\
& 4,00 & 50 & 69,6588 & 69,6588 \\
& 7,00 & 50 & & 73,9434 \\
& Sig. & &, 276 &, 168 \\
\hline
\end{tabular}

Es ev $=2013,00 \mathrm{kez}=C$

\begin{tabular}{|cc|c|c|c|c|}
\hline \multirow{2}{*}{ zsplusz } & & \multirow{2}{*}{$\mathrm{N}$} & \multicolumn{3}{|c|}{ Subset } \\
\cline { 4 - 6 } & & & 1 & 2 & 3 \\
\hline \multirow{4}{*}{ GH } & 2,00 & 50 & 69,9986 & & \\
& 3,00 & 50 & 74,6244 & 74,6244 & \\
& 4,00 & 50 & & 77,6710 & 77,6710 \\
& 5,00 & 50 & & & 82,5546 \\
& 7,00 & 50 & & & 82,8554 \\
& Sig. & &, 413 &, 783 &, 295 \\
\hline
\end{tabular}

Es ev $=2012,00 \mathrm{kez}=\mathrm{LM}$

\begin{tabular}{|cr|c|c|}
\hline \multirow{2}{*}{ zsplusz } & \multirow{2}{*}{$\mathrm{N}$} & Subset \\
\cline { 4 - 4 } & & & 1 \\
\hline & 2,00 & 50 & 66,0590 \\
& 5,00 & 50 & 68,5756 \\
Tukey & 3,00 & 50 & 71,3726 \\
HSD $^{\text {a,b,c }}$ & 7,00 & 50 & 73,1188 \\
& 4,00 & 50 & 73,4646 \\
& Sig. & &, 070 \\
\hline
\end{tabular}

Es ev $=2013,00 \mathrm{kez}=$ LM

\begin{tabular}{|c|c|c|c|c|c|c|}
\hline \multirow{2}{*}{ zsplusz } & & \multirow{2}{*}{$\mathrm{N}$} & \multicolumn{4}{|c|}{ Subset } \\
\hline & & & 1 & 2 & 3 & 4 \\
\hline \multirow{6}{*}{$\begin{array}{l}\text { Tukey } \\
\text { HSD }^{\mathrm{a}, \mathrm{b}, \mathrm{c}}\end{array}$} & 2,00 & 50 & 66,0580 & & & \\
\hline & 3,00 & 50 & 71,7672 & 71,7672 & & \\
\hline & 4,00 & 50 & & 78,6408 & 78,6408 & \\
\hline & 7,00 & 50 & & & 80,3728 & 80,3728 \\
\hline & 5,00 & 50 & & & & 87,3606 \\
\hline & Sig. & & ,272 & ,119 & ,974 & , 108 \\
\hline
\end{tabular}


Ws ev $=2012,00 \mathrm{kez}=\mathrm{C}$

\begin{tabular}{|cc|c|c|}
\hline \multirow{2}{*}{ zsplusz } & & $\mathrm{N}$ & Subset \\
\cline { 4 - 4 } & & & 1 \\
\hline & 7,00 & 50 & 3,0324 \\
& 3,00 & 50 & 3,0576 \\
Tukey & 4,00 & 50 & 3,0846 \\
HSD $^{\mathrm{a}, \mathrm{b}, \mathrm{c}}$ & 5,00 & 50 & 3,0981 \\
& 2,00 & 50 & 3,2517 \\
& Sig. & &, 265 \\
\hline
\end{tabular}

Ws ev $=2013,00 \mathrm{kez}=C$

\begin{tabular}{|cc|c|c|c|}
\hline \multirow{2}{*}{ zsplusz } & & \multirow{2}{*}{$\mathrm{N}$} & \multicolumn{2}{|c|}{ Subset } \\
\cline { 4 - 5 } & & & 1 & 2 \\
\hline & 3,00 & 50 & 2,3436 & \\
& 4,00 & 50 & 2,3588 & \\
Tukey & 2,00 & 50 & 2,4089 & \\
HSD $^{\mathrm{a}, \mathrm{b}, \mathrm{c}}$ & 7,00 & 50 & 2,4992 & 2,4992 \\
& 5,00 & 50 & & 2,6398 \\
& Sig. & &, 325 &, 430 \\
\hline
\end{tabular}

Ws ev=2012,00kez $=$ LM

\begin{tabular}{|c|c|c|c|}
\hline \multirow{2}{*}{ zsplus } & & \multirow{2}{*}{$\mathrm{N}$} & Subset \\
\hline & & & 1 \\
\hline \multirow{6}{*}{$\begin{array}{c}\text { Tukey } \\
\text { HSD }^{\mathrm{a}, \mathrm{b}, \mathrm{c}}\end{array}$} & 2,00 & 50 & 2,9370 \\
\hline & 5,00 & 50 & 3,0542 \\
\hline & 4,00 & 50 & 3,0680 \\
\hline & 7,00 & 50 & 3,1391 \\
\hline & 3,00 & 50 & 3,2211 \\
\hline & Sig. & & 075 \\
\hline
\end{tabular}

Ws ev $=2013,00 \mathrm{kez}=\mathrm{LM}$

\begin{tabular}{|cc|c|c|}
\hline \multirow{2}{*}{ zsplusz } & & $\mathrm{N}$ & Subset \\
\cline { 4 - 4 } & & & 1 \\
\hline & 3,00 & 50 & 2,3607 \\
& 2,00 & 50 & 2,4013 \\
Tukey & 7,00 & 50 & 2,5087 \\
HSD ${ }^{\mathrm{a}, \mathrm{b}, \mathrm{c}}$ & 5,00 & 50 & 2,5315 \\
& 4,00 & 50 & 2,5925 \\
& Sig. & &, 054 \\
\hline
\end{tabular}




\section{KÖSZÖNETNYILVÁNÍTÁS}

Az út, amin idáig eljutottam, számos tapasztalatot, élményt adott, ugyanakkor kihívásokban is bővelkedett. Ezek legyőzéséhez szerencsére sok embertől kaptam segítséget és támogatást. Mindenekelőtt köszönetet szeretnék mondani témavezetőimnek, Dr. Zsófi Zsoltnak és Dr. Pásti Györgynek, hogy a kísérlet során és az értekezés megírása közben mindvégig iránymutatást adtak. Köszönet illeti Dr. Kállay Miklós Professzor Urat, aki a doktori cselekményem megkezdését lehetővé tette és tanácsaival, ötleteivel munkámat segítette. Köszönöm, hogy Dr. Bálo Borbála révén, kutatásaimat az egri Szőlészeti és Borászati Kutatóintézetben elkezdhettem. Balga Irina, Isóné Bendász Nelli, Kőteleky Katalin az analitikai módszerek betanításában, kivitelezésében nyújtott sok segítséget. A kísérleti boraim analízisét Dobóczkyné Tóth Judit és Géher Lászlóné, míg a HPLC-vel történő vizsgálatokat Dr. Leskó Annamária és Hegyiné Kiss Zsuzsa, a BCE Borászati Tanszékének munkatársai végezték. A kapott adatok statisztikai kiértékelése Dr. Ladányi Márta fáradhatatlan és végletekig precíz munkája révén valósult meg. A távérzékelésnél és a kísérleti területek térképeinek elkészítésénél Dr. Burai Péter volt a segítségemre. Köszönöm Lénárt Tamás, Pálmai Zsolt és Tick Zoltán kitartó munkáját, amit a kísérleti szőlő feldolgozása során végeztek. Köszönöm Dr. Geoffrey R. Scollarynak, Carlos Suárez Martíneznek, Karl Burgernek, Dr. Lukácsy Györgynek, valamint Dr. Kovács Tamásnak a szakmai egyeztetéseket, beszélgetéseket. A kísérlet kezdeti szakaszában Herczeg Ágnes nemzetközi borakadémikus, Master of Wine aspiráns szavai, gondolatai meghatározóak voltak a későbbi munka egészére nézve. A megfelelő borászati technológia kidolgozásában Adamovich Károly és Benedek Péter voltak a segítségemre. A lombtrágyát és a kísérleti borok kierjesztéséhez szükséges élesztőket, segédanyagokat a Lallemand és a Kokoferm Kft. biztosította. Sok, a gyakorlatra nézve hasznos tanácsot kaptam Balga Istvántól, Stefán Tibortól és Patai Istvántól. Nagy köszönettel tartozom továbbá Kovács Gábornak a Gróf Buttler Borászati Zrt. tulajdonosának, valamint Pócs János egykori és Mikuska Péter jelenlegi vezérigazgató uraknak, hogy kísérletemet a borászat érdekeltségébe tartozó szőlőültetvényben állíthattam be és végezhettem három éven keresztül.

A PhD tanulmányok megkezdése, lefolytatása, a fokozat megszerzése és a dolgozat elkészülése nem sikerülhetett volna a TÁMOP-4.2.2/B-10/1-2010-0023 és a TÁMOP-4.2.1/B-09/1/KMR2010-0005 pályázatok anyagi támogatása nélkül.

Végül, de nem utolsósorban hálás köszönettel tartozom Feleségemnek, Hannának és Szüleimnek, illetve Testvéremnek, akik a munkavégzés alatt mindvégig megfelelő hátteret biztosítottak, megértettek, támogattak. 